\title{
Musci Exotici;
}

CONTAINING

\section{FIGURES AND DESCRIPTIONS}

of

NEW OR LITTLE KNOWN

\section{FOREIGN MOSSES}

\author{
AND OTHER
}

\section{CRYPTOGAMIC SUBJECTS.}

BY

WILLIAM JACKSON HOOKER, F.R.A. AND L.S. \&c, REGIVS PROFESSOR OF BOTANY IN THE UNIVERSITT OF GLASGOW.

$$
\text { VoL. II. }
$$

"Quis autem tale studium, quo ad aternam omnium rerum causam ovehimur, tamquam inutile ac contemnendum detrectare ac deprimere ausit?"-BRIDEL.

\section{LONDON :}

PRINTED BY RICHARD AND ARTHUR TAYLOR, SHOE LANE :

FOR LONGMAN, HURST, REES, ORME, AND BROWN, PATERNOSTER-ROW.

1820. 


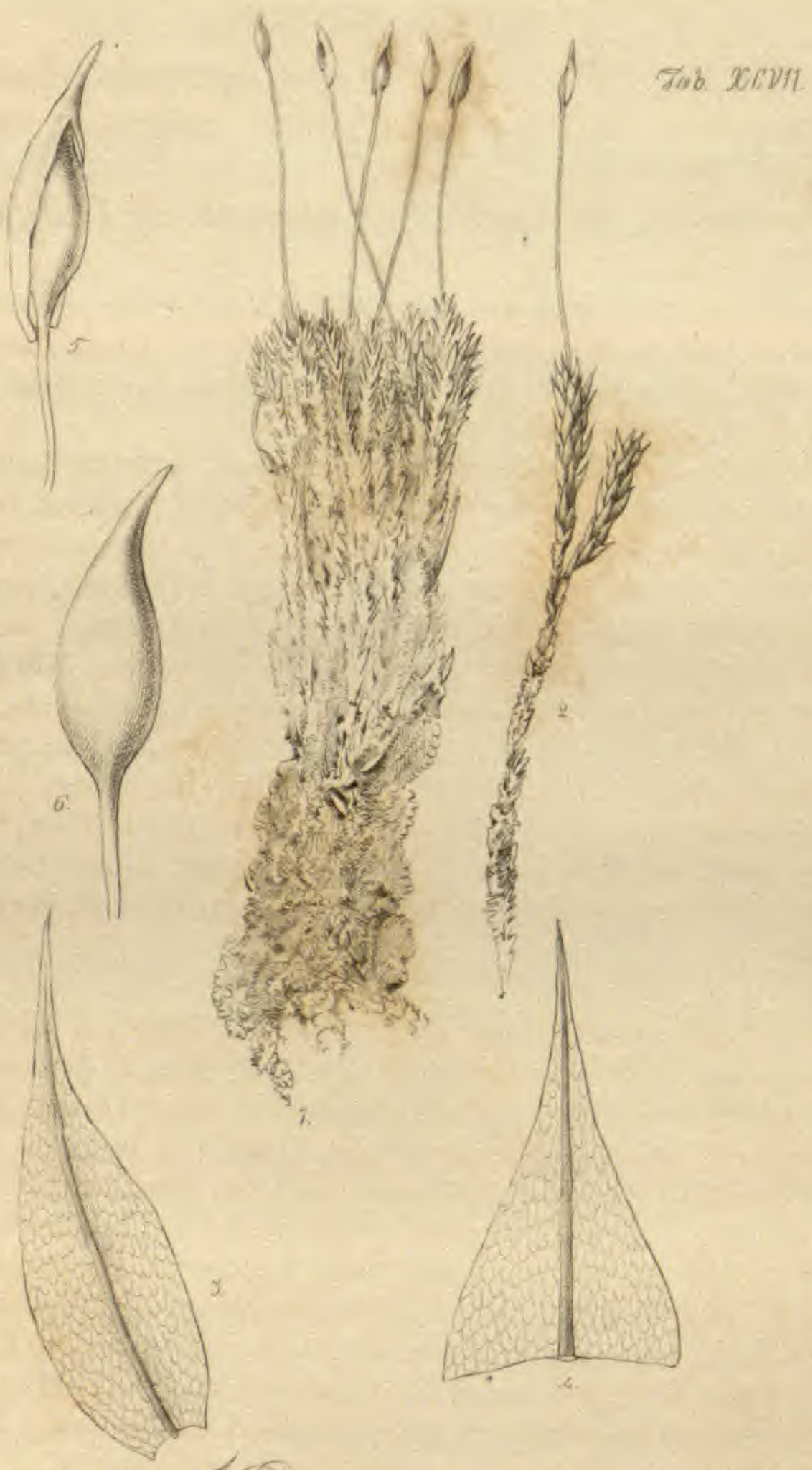

\section{Watha nuvalis}

Gowobse Mest 
VOITIA NIVALIS.

Gen. Char. Perist. 0. Caps. operculo adnata, cum pedunculo decidua. (Calyptra magna persistens.) (TAв. XCVII.)

Voitia nivalis. Hornsch, in Comment. de Voit. et Syst. p. 5. t. 1 .

HAB. In summis montibus Carinthiæ, ad limites extremos nivis æternæ, ubi in societate Splachni urceolati placentas stercoris vaccini vetustas siccas cæspitibus læte virentibus obtegit. D. Prof. Hornschuch.

Caules bi-triunciales, densissime cæspitosi, inferne tomento ferrugineo obsiti, superne subramosi. Folia undique imbricata, erecto-patentia, ovata, cuspidato-acuminata, concava, lætevirentia, subpellucida, areolis oblongis reticulata, nervo tenui saturatiore ad summum acumen usque percursa. Setce unciales et ultra crassiusculæ, pallide flavo-fuscæ. Capsula (una cum operculo) ovata vel oblongo-ovata, oblique acuminata, saturate fusca, apice pallidiore, "nunquam dehiscens, sed una cum operculo suo, basi humore et putredine soluto decedens." Calyplra dimidiata, magna, capsula paulo longior, flavo-fusca, "capsulæ tam arcte adglutinata, ut in maturitatem usque persistat, et non, nisi tempestatum et pluviarum injuriis demum exesa, solvetur."

At the commencement of a second volume, I find myself, through the liberal contribution of my friends, in possession of a larger stock of unpublished materials than when I began the work. In addition to numerous species from the tropics and the southern hemisphere, I have just had the pleasure of receiving several new European mosses from Professor Hornschuch, collected by him in the Tyrolian, Salzburgian and Carinthian Alps; and I think I cannot better show the value which I set upon these communications, than by hastening to lay them before the public.

The plant before us is not the least curious among them, having the characters hitherto generally ascribed to the genus Phascum, but at the same time a large and persistent calyptra, a fruitstalk which decays with the capsule, and other marks of less importance, taken from what are supposed to be the male fructification, which have induced the learned discoverer of this plant (in a memoir entitled "De Voitia et Systilio novis Muscorum Frondosorum Generibus Commentatio,") to form of it a distinct genus. Should these characters be considered by others as of sufficient importance, Phascum will be thus distinguished: "Perist. 0. Caps. operculo adnata et pedunculo decidua. (Calyptra brevis fugax.)" And $P$. bryoides will then form a closely eonnecting link.

Fig. 1, tuft of plants; and Fig. 2, single plant, nat. size.Fig. 3, leaf. Fig. 4, extremity of a leaf. Fig. 5, capsule and calyptra. Fig. 6, capsule.-magn.

Vot. II. 
SYSTILIUM SPLACHNOIDES.

Gen. Char. Perist. simplex; dent . sedecim parium brevibus, basi conjunctis. Operculum cum columella connatum, persistens. (Capsula cum apophysi.) Hornschuch. (ТАв. XCVIII.)

Systilium splachnoides. Hornsch, in Comment. de Voit. et Systil. p. 14. t. 2.

$\mathrm{H}_{\mathrm{AB}}$. Ad rupem micaceo-schistosam, unico tantum loco, in alpibus Carinthiæ superioris. D. Prof. Hornschuch.

Caules cæspitosi, 3-4-lineares, rubicundi, plerumque simplices. Folia undique imbricata, favo-viridia, basi rubedine tincta, erecta, ovata, concava, apice obtusa, margine omnino integerrima, nervo ad apicem attingente ; substantia pellucida, pulcherrime reticulata, areolis grandiusculis oblongis. Setce semiunciam longæ, crassiusculæ, flavæ. Capsula (una cum apophysi paulo breviore) elongato-pyriformis, maturitate flavofusca, siccitate angustior. Operculum conico-obtusum, flavum, intus columellæ filiformi post capsulæ dehiscentiam et seminum emissionem usque adnatum. " Calyptra," secundum cl. Hornschuch, " conica, obtusa cum papilla, lævis, flavescens, adulta campanulata." Peristomium e dentibus 32, paulo intra marginem capsulæ insertis, brevibus, rufis, subincurvis, per paria approximatis atque basi connatis, siccitate erectis.

This new genus is established by Professor Hornschuch, as well as the preceding one, in the Memoir above quoted. To the correctness of the characters there laid down I can bear ample testimony. The operculum firmly adheres to the apex of the columella, not only after it has separated from the mouth of the capsule, but after the dispersion of the seeds, when the seminal bag is left empty within the capsule; as represented in our plate, fig. 6 . The teeth too are 32 in number, or 16 pairs; in this particular differing essentially from Splachnum, but then it is to be regretted that the habit of the plant is so entirely that of a Splachnum, and especially that of S. Froelichianum, that, except in the marks which indicate the genus, it would be difficult to find points of distinction. The capsule is, however, narrower, and the fruitstalk shorter. Systilium resembles Splachnum scabrisetum of this work, and also Hookeria splachnoides of Schwaegrichen, (Tayloria mihi) in the point of insertion of the peristome, but differs from the former in the number, and from the latter in the shortness and straightness, of the teeth.

Fig. 1, tuft of plants; and Fig. 2, single fertile plant, nat. size. Fig. 3, single sterile ditto. Fig. 4, leaf. Fig. 5, young capsule with the calyptra (from Hornschuch's figure). Fig. 6, mature capsule cut open to show the union of the columella with the operculum after the discharge of the seeds. Fig. 7, capsule and portion of the peristome (outside view). Fig. 8 , portion of the peristome seen within the capsule,-magn. 

Bripum denrefrum.

Evarad for 


\section{BRYUM DEMISSUM.}

Bryum caule perbrevi ramoso, foliis ovatis cuspidato-acuminatis reticulatis, nervo excurrente, seta arcuata, capsula curvato-pyriformi pendula. (TAB. XCIX.)

Meesia demissa. Hoppe et Hornsch. MSS.

Timmiæ nov. sp. Schmidt MSS.

Bryum curvulum. Schleicher MSS.

HAB. In monte Cenisii, supra 7000 pedum elevationem reperi. 1814. Unicum parvulum cæspitem in summo cacumine alpis Wingsfield Opdaliæ Norvegiæ transalpinæ solummodo legit D. Prof. Schmidt. In alpibus Tyrolensibus. D. Prof. Hornschuch.

Caules cæspitosi ferrugineo-tomentosi, vix duas lineas longi, ad basin fastigiatim ramosi, sed, ut videtur, innovationibus præcipue. Folia flavo-viridia, basi purpurascente, arcte imbricata, erecta, concava, ovata, cuspidato-acuminata, margine integerrima, nervo fusco, superioribus, in acumen piliforme excurrente prædita, reticulata areolis oblongis, grandiusculis. Seta semiuncialis, crassiuscula, flexuosa, superne insigniter arcuata. Capsula matura flavo-rufescens, oblongo-pyriformis, curvata, pendula. Os minutum. Operculum conicum. Peristomii externi dentes 16 longiusculi, acuminati, transversim striati, albopellucidi, basi aurantiaca, int. cilia sæpissime per paria ad apicem connexa, atque hic illic processubus transversalibus unita. Calyptram non vidi.

I first saw this singular moss in a botanical excursion made in the summer of 1814, near to one of the highest summits of Mont Cenis. It was soon after communicated to me by the late lamented Professor Schmidt as a new Timmia. I have again received specimens from Prof.Hornschuch under the name of Meesia demissa, and from M. Schleicher under that of Bryum curvulum. It must be allowed, however, that in point of natural habit it has little or no connexion either with the Timmia or Meesice; but that if the figure of the internal peristome is allowed of sufficient importance to characterize the genus, it must be arranged with the former. To me its most natural place appears to be among some of our well known Brya. To B. caespititium it approximates in its leaves, though they are of a laxer texture, and to $B$. Zierii in the form of its capsule.

Fig. 1, tuft of plants, nat. size. Fig. 2, single plant. Fig. 3, leaf. Fig. 4, capsule. Fig.5, operculum. Fig.6, portion of outer peristome. Fig. 7, portion of inner ditto.-magn. 


\section{GRIMMIA ATRATA.}

Grimmia caule brevi subramoso, foliis erecto-patentibus lanceolato-subulatis, apicibus obtusiusculis concoloribus, nervo crasso, seta exserta, capsula oblongo-ovata, operculo conico. (ТАB. C.)

\section{Grimmia atrata. Hoppe et Hornsch. MSS.}

$\mathrm{H}_{\mathrm{AB}}$. Ad rupes in valle Grosarl in alpibus Salisburgensibus legit D. Hornschuch.

Caules dense pulvinati, vix duas lineas longi, simplices vel hie illic ramosi. Folia undique imbricata, erecto-patentia, siccitate etiam stricta, lanceolato-subulata, canaliculata, apice obtusa concolora, margine omnino integerrima; inferiora intense nigro-fusea, superiora atro-viridia, omnia nervo crasso colore intensiore ad apicem percurrente prædita. Seta bi-tri-linearis, erecta, stricta. Capsula oblongo-ovata, viridi-fusca, demum nigra. Operculum conico-obtusum. Calyptra deest. Peristomium e dentibus constans 16 , latiusculis, acutis, transversim striatis, flavicantibus, integerrimis, sed hic illic prope apicem linea media longitudinali,

The calyptra of this minute plant $I$ have not myself seen. Its discoverers have placed it among the Grimmia, where it may be placed near $G r$. ovala, from which it is easily distinguished by its lesser size, very dark colour, the obtuse and colourless points to the leaves, with their thickened nerve and the narrow capsules, which become black when the plant is past maturity. Indeed the whole plant has a remarkably lurid aspect, and grows in dense tufts, which are peculiarly even on their surface.

Fig. 1, tuft of plants, nal, size. Fig.2, single plant. Fig, 3, leaves. Fig, 4, teeth of the peristome, $-\operatorname{mag} n$. 
รab $C$.

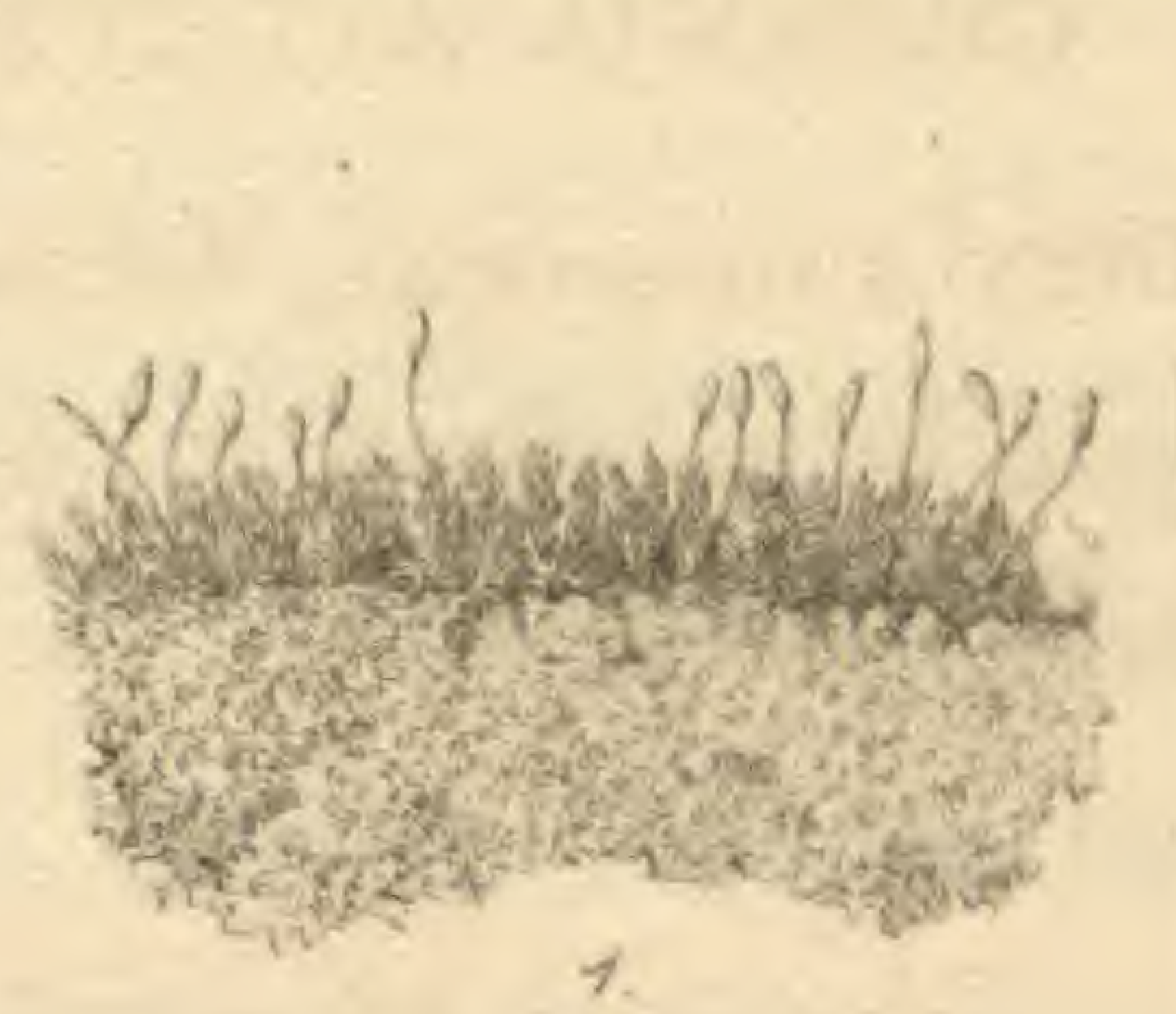

(⿻)

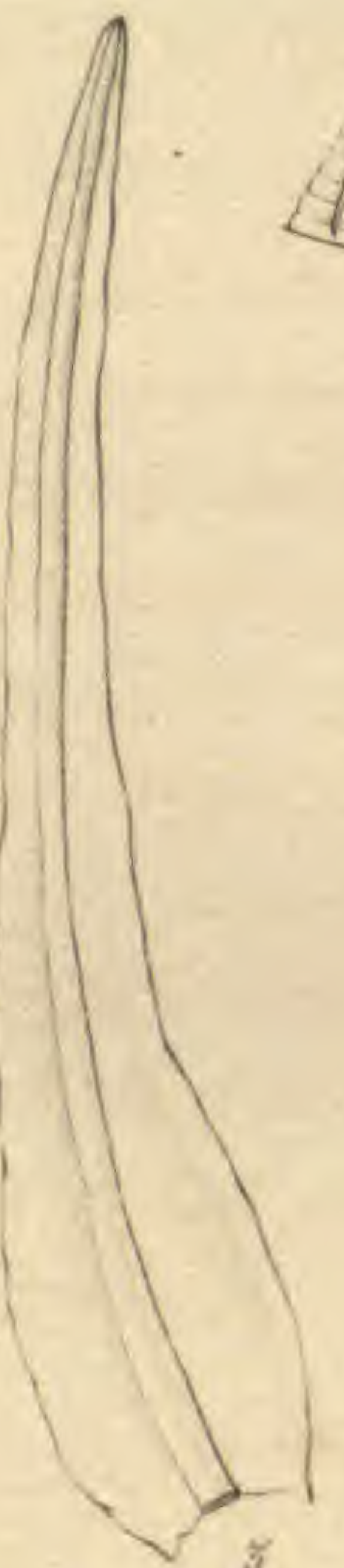

$\sqrt{1}$
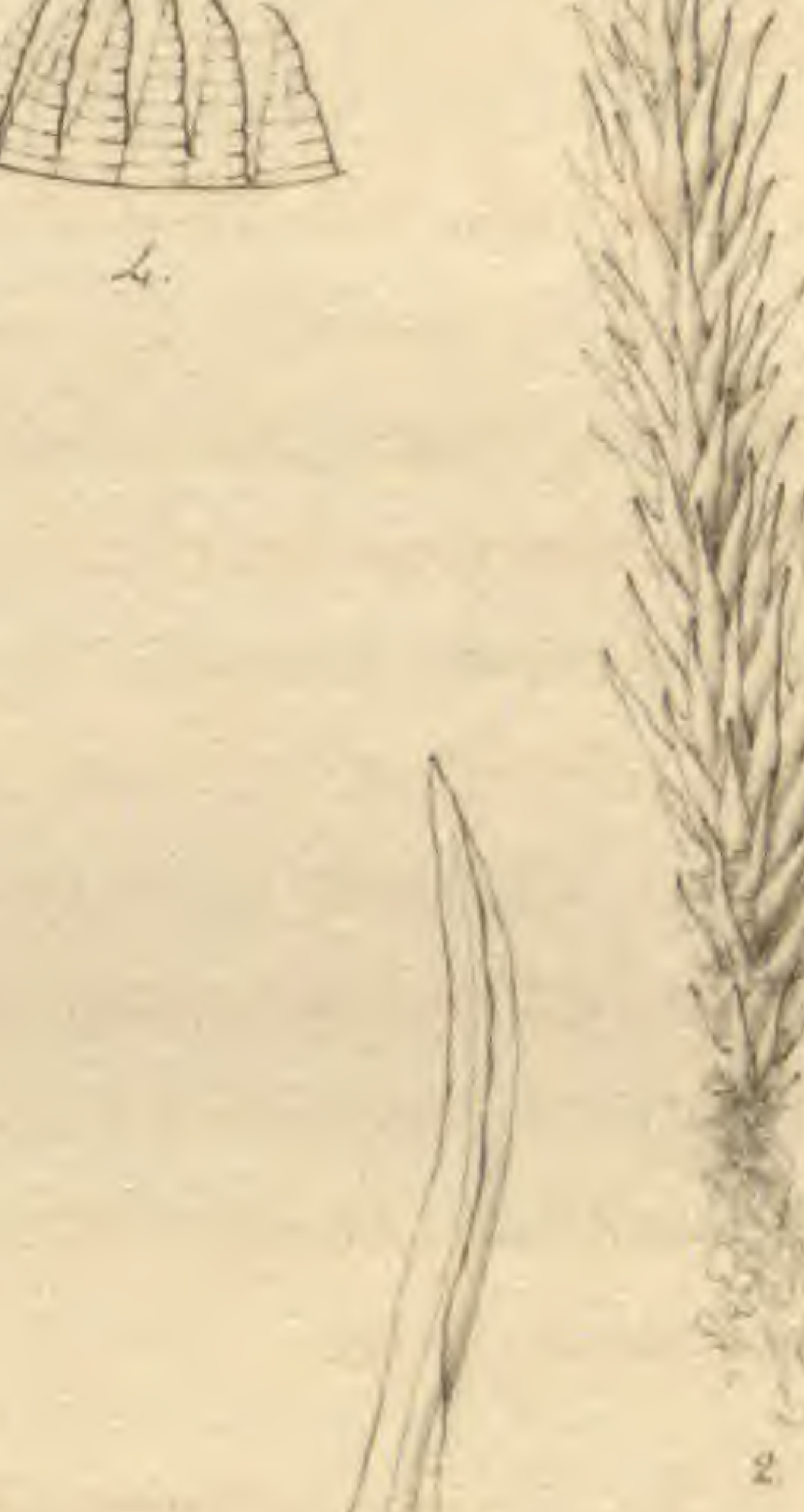

ivel, +3$) / 2$,

sule 1 ive?

ven, wef

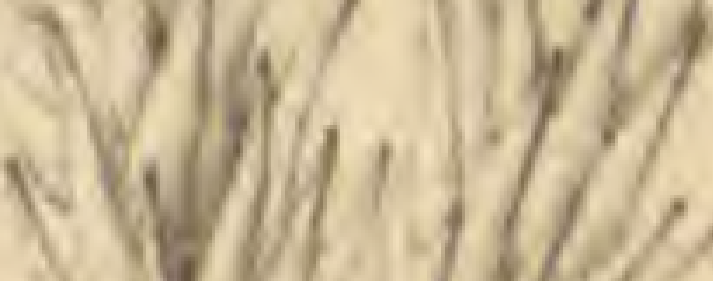

No

1)

Niv
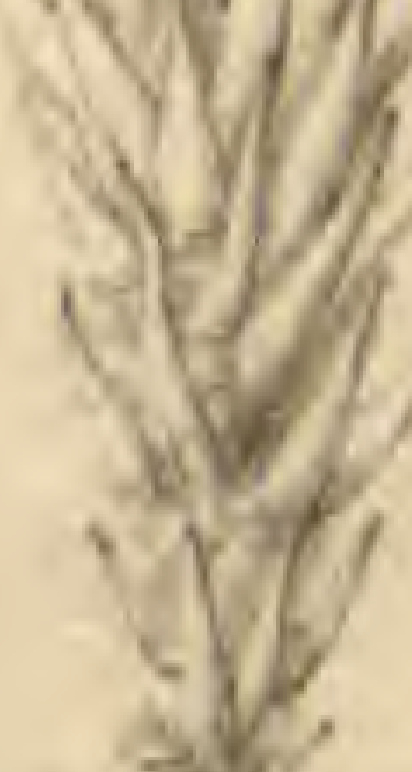

s.

4

c.1

2

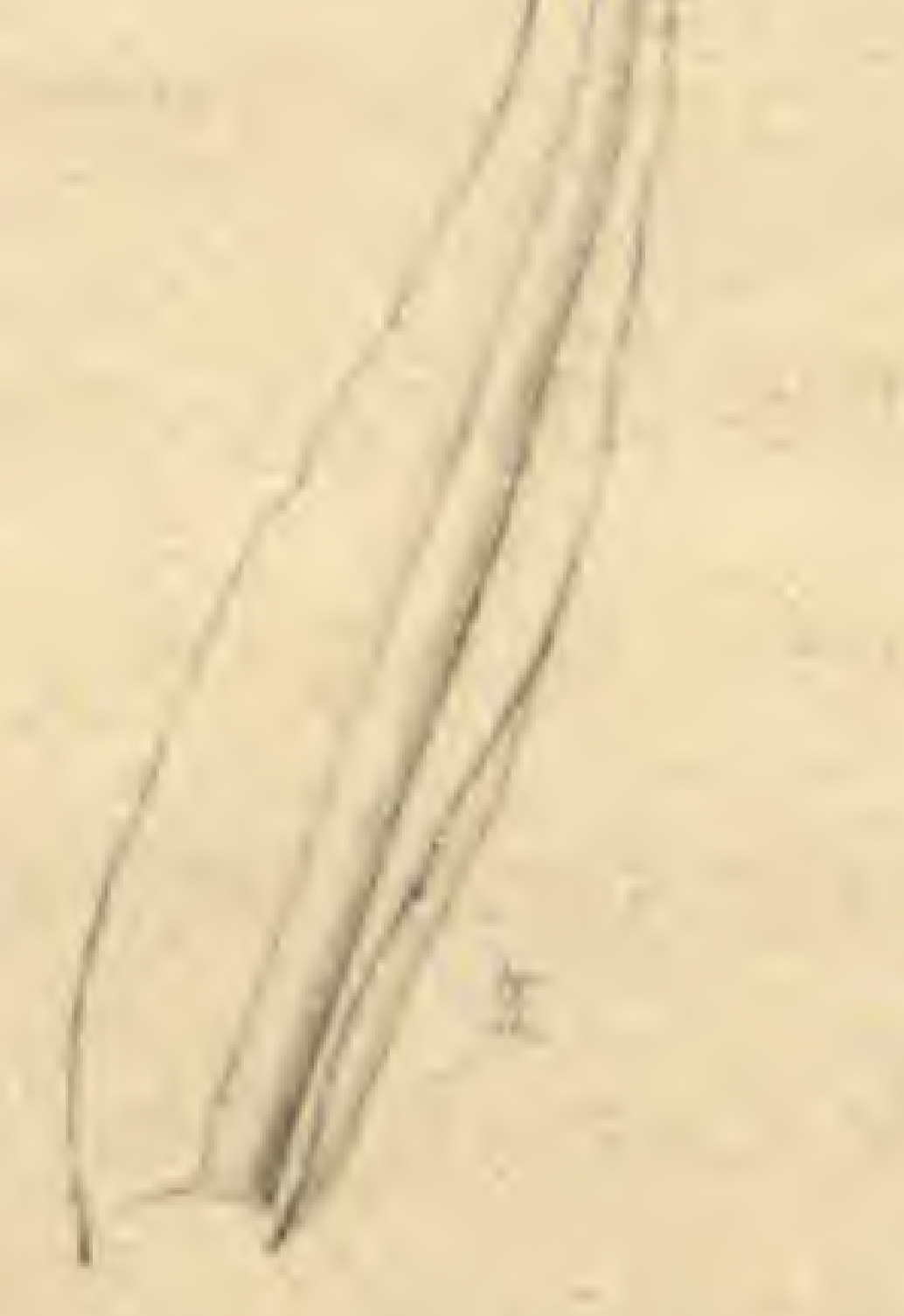

Gummia ariatas 


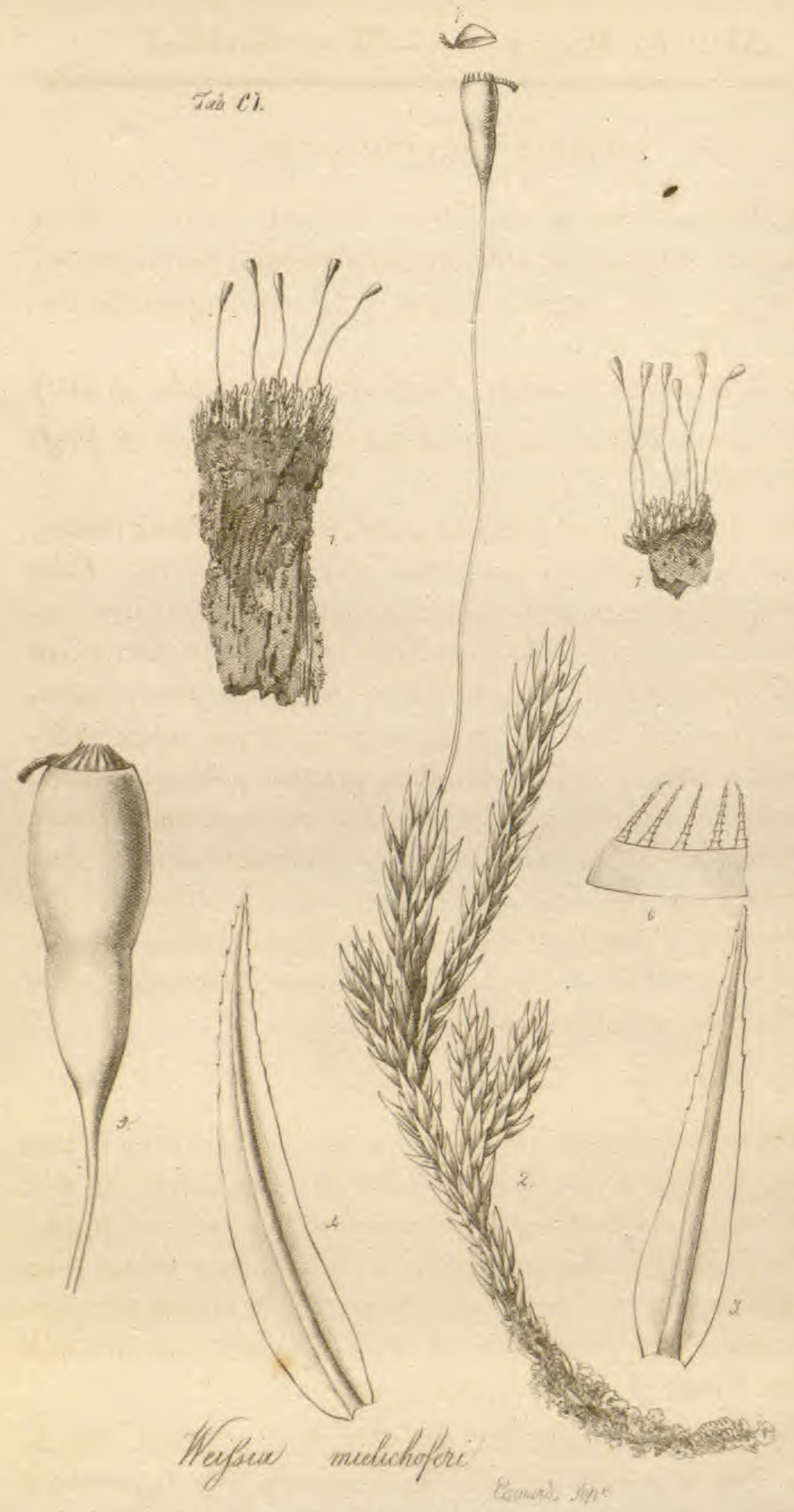




\section{WEISSIA MIELICHOFERI.}

Weissia caule dense cæspitoso elongato ramoso, foliis anguste lanceolatis subserrulatis rigidis, nervo crasso, seta elongata, capsula erecta pyriformi, operculo conico. (TAB. CI.)

Weissia Mielichoferiana. Funk. (fide Hornsch. in litt.)

$\mathrm{H}_{\text {AB. }}$ In valle Grosarl in alpibus Salisburgensibus legit D. Prof. Hornschuch.

Caules bi-trilineares ad unciales, erecti, dense cæspitosi, ramosi, ramis brevibus, erecto-patentibus, apicibus subacutis. Folia undique imbricata, erecto-patentia, luteo-viridia, inferiora fuscescentia, omnia anguste-lanceolata, rigida, vix serrulata, nervo valido intense rufo-fusco, ad apicem usque attingente prædita. Perichatialia longiora, magis angusta, atque colore pallidiora, Seta, e ramulis brevibus, gracilis, pollicaris, erecta, fiexuosa. Capsula flavo-fusca, erecta, vel paululum inclinata, oblongo-pyriformis, infra medium subcontracta et quasi apophysata, ore annulato. Operculum conicum, obtusum. Peristomium e dentibus sedecim pallide flavescentibus, distantibus, a basi latiore sensim attenuatis, transversim striatis et quasi articulatis, articulis medio contractis.

Weissia Mielichoferi, though it has truly the peristome of that genus, yet departs from it considerably in habit, and at the first aspect might rather seem to elaim some affinity with the Brya.

The leaves are peculiarly rigid, a circumstance arising from the thickness of the nerve; and the capsule is remarkably pyriform, resembling greatly that of $W$. Templetoni, near to which species it ought to take its place in the genus.

Fig. 1, tufts of plants, nat. size. Fig. 2, single plant. Fig. 3. leaf. Fig. 4, perichætial leaf. Fig. 5, capsule. Fig. 6, portion of a capsule with the teeth of the peristome. Fig. 7, opereulum with a portion of the annulus adhering to it,-magn. 


\section{WEISSIA ELONGATA.}

Weissia caule densissime cæspitoso elongato ramoso, foliis arcte imbricatis lanceolato-ovatis obtusis reticu latis integerrimis, nervo sub summo apice evanescente, seta flexuosa, superne arcuata, capsula ovata (ob directionem setæ) inclinata vel pendula, operculo conico. (Tав. CII.)

Weissia elongata. Hoppe et Hornschuch MSS.

НАв. In valle Grosarl in alpibus Salisburgensibus legit $\mathrm{Cl}$. Hornschuch.

Caules bi- ad 4-unciales in cæspitibus densissime compacti, elongati, graciles, filiformes, flexuosi, parum ramosi. Folia undique imbricata, erecta, appressa, parum concava, late lanceolato-ovata, areolis oblongis pulcherrime reticulata, flavo-víidia, inferiora fusco-nigrescentia, margine vix serrata, nervo satis valido sub summo apice evanescente instructa. Pericheetialia, exteriora caulinis similia, inleriora lanceolata, nervo obscuriore. Seta flavescens, terminalis flexuosus, superne ut cygni collum curvata. Capsula secundum setæe curvaturam inclinata vel pendula, ovata, pallide fusco-viridis. Operculum conicum, obtusum, flavum. Peristomium e dentibus 16 subdistantibus pallide flavescentibus longiusculis attenuatis transversim striatis.

This is another new Moss discovered by Professor Hornschuch, differing in so many respects from any other known moss, that it is hard to say to which it approaches the nearest. The stems and foliage most resemble small specimens of Bryum julaceum; but the fructification is very remarkable, having the fruitstalk curved below the capsule, like the neck of a swan, and the capsule either inclined or pendent according to the degree of curvature.

Fig. 1, 1, tufts of plants, nat. size. Fig. 2, single plant. Fig.3, leaf. Fig. 4, outer, and Fig. 5, inner perichætial leaf. Fig. 6, mouth of the capsule and peristome. Fig. 7, teeth of the peristome, $-m a g n$. 
Tak cis.

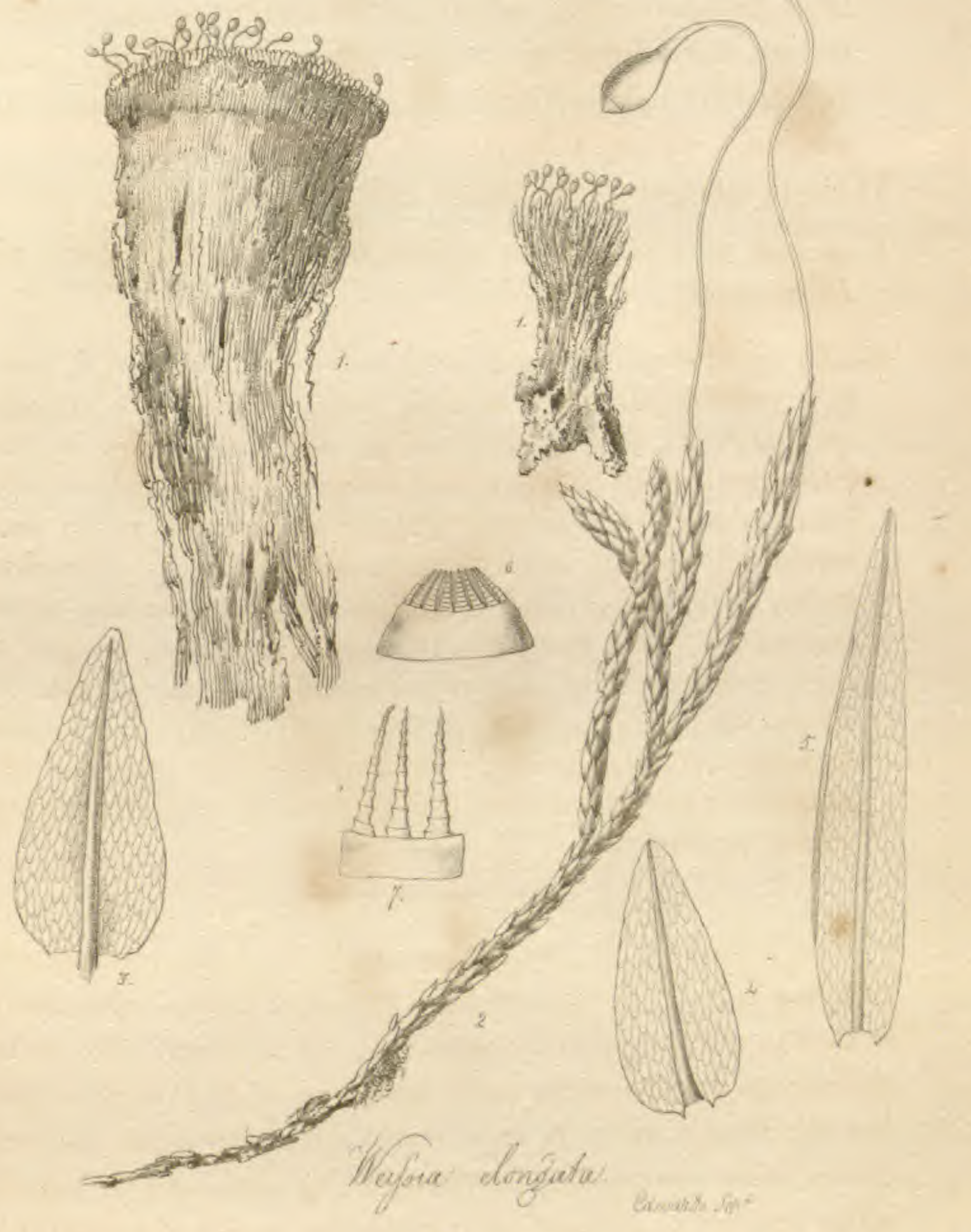




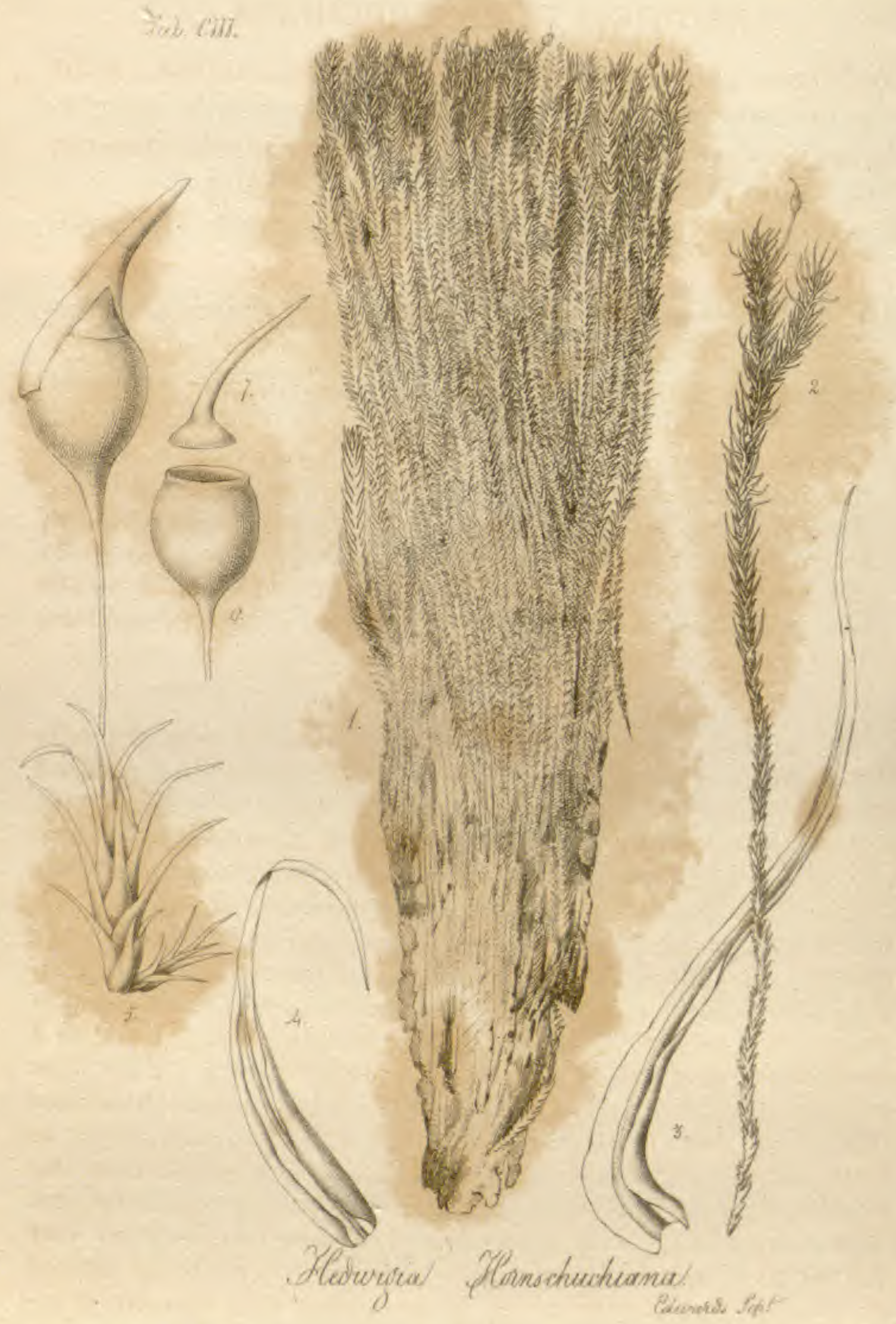




\section{HEDWIGIA HORNSCHUCHIANA.}

Hedwigia caule crespitoso elongato subramoso, foliis longe subulatis flexuosis patentibus carinatis integerrimis, nervo lato, seta laterali brevi, capsula globosa, operculo oblique longirostro. (TAB. CIII.)

Anictangium Hornschuchianum. Funk. (fide Hornsch. in litt.)

$\mathrm{H}_{\mathrm{AB}}$. Ad rupes madidas prope Heiligenblul in alpibus Carinthiacis superioribus. D. Prof. Hornschuch.

Caules palmares, dense cæspitosi, erecti, flexuosi, superne subramosi. Folia undique inserta, patentia, longe subulata, carinata, flexuosa, integerrima, nervo lato prædita, superiora flavo-viridia, reliqua fusea. Perichatialia setæ dimidio longitudinis, basi vaginata, apicibus recurva, nervo tenui. Seta lateralis, prope apicem ramorum, vix tres lineas longa, erecta. Capsula globosa, pallide viridi-fusca, ore rufo. Operculum flavescens basi rufum, longirostratum, rostro obliquo. Calyptra subulata, lateraliter fissa.

The genus Aniclangium of Hedwig is founded upon the axillary situation of the anthers, taken in conjunetion with the naked mouth of the capsule; characters these, not easily to be discovered, and which, according to those species which have been taken into that genus by Schwaegrichen, compose a most unnatural assemblage.-Six species out of the ten enumerated by the last-mentioned author, are indeed universally allowed to belong to other genera. My friend Dr. Taylor and myself have ventured to propose other characters for this genus, taken from the calyptra, in conjunction with the insertion of the fruitstalk; and hitherto I have every reason to be satisfied with these marks. They have certainly the advantage of being more readilydiscerned than those of Hedwig, and the species which they bring together, as far as I am yet acquainted with them, do not so greatly recede from one another in general habit, as to render the genus an unnatural one. The species here under consideration has its fructification very similar to a Humboldtian plant which remains yet to be figured in this work, but from which in its foliage it is abundantly distinct. Indeed the stems and leaves of H. Hornschuchiana, when seen with the naked eye, are more like those of Bartramia Halleriana than those of any plant I know.

Fig. 1, tuft of plants; and Fig. 2, single plant, nat. size. Fig. 3, leaf. Fig. 4, perichætial leaf. Fig. 5, perichætium, fruitstalk, capsule and calyptra. Fig. 6, capsule, with, Fig. 7, the operculum removed.- magn. 


\section{WEISSIA MARTIANA.}

Weissia caule densissime cæspitoso elongato subramoso, foliis lanceolato-subulatis patentibus siccitate crispatulis, seta breviuscula curvata, capsula globosa sulcata. (ТАв. CIV.)

Weissia Martiana. Hoppe et Hornsch. MSS.

HaB. In alpibus Tyrolensibus. D. Hornschuch.

Caules 3-4-pollicares, erecti, densissime cæspitosi, suhramosi innovationibus præcipue, ferrugineo-tomentosi, apicibus solummodo viridibus. Folia undique imbricata, horizontaliter patentia, pallide viridia, lanceolato-subulata, carinata, integerrima, margine subrecurvo, nervo saturatiore instructa. Perichcetialia reliquorum similia, sed margine non recurvo. Seta vix bilinearis sæpe ob innovationes lateralis, pallide flavo-fusca, insigniter curvata. Capsula recta, globosa, rufo-fusca, profunde sulcata, sulcis viridi-fuscis. Operculum et Calyptra desunt. Peristomium intense rubrum, dentibus 16, longiusculis, basi latis, apice attenuatis, transversim striatis, siccitate æque ac madore subhorizontaliter positis intra marginem capsulæ.

This singular plant, which has been found only by Professor Hornschuch in the Tyrolian Alps, is at once distinguished from every other species of the genus by its curved fruitstalk and the globose and deeply sulcated capsule. Its nearest ally is $W$. nigrila : but, independently of the marks now pointed out, there is a remarkable curvature in the capsule of the last-mentioned species, whilst in G. Martiana it takes its direction from that of the fruitstalk.

Fig. 1, tuft of plants; and Fig. 2, single plant, nat.size. Fig. 3, leaf. Fig. 4, fruitstalk and capsule. Fig. 5, portion of the peristome,-magn. 
Tab $l W$
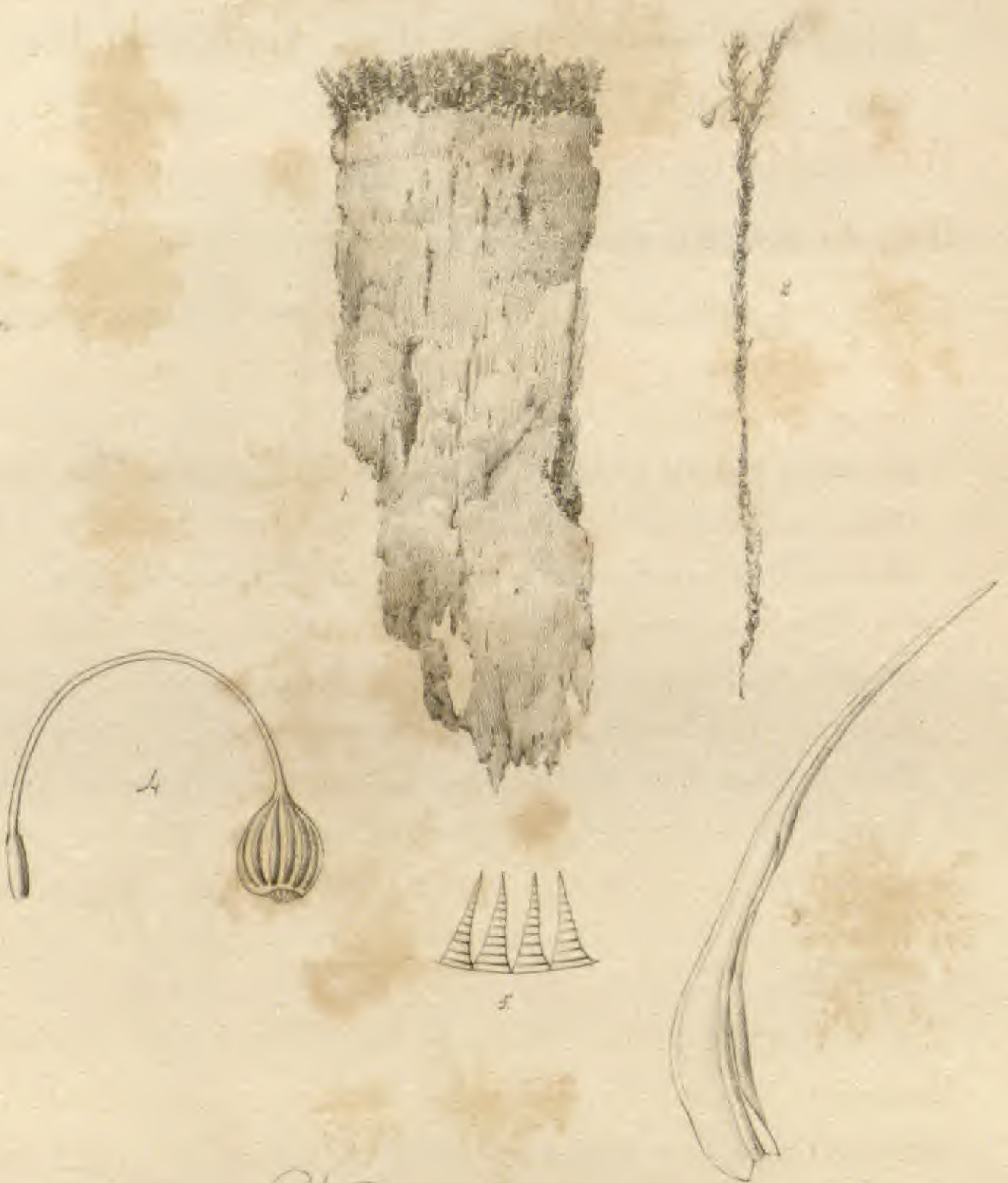

Heviaw Alaticuma

Bunetidi sop 2 
Jab CD.
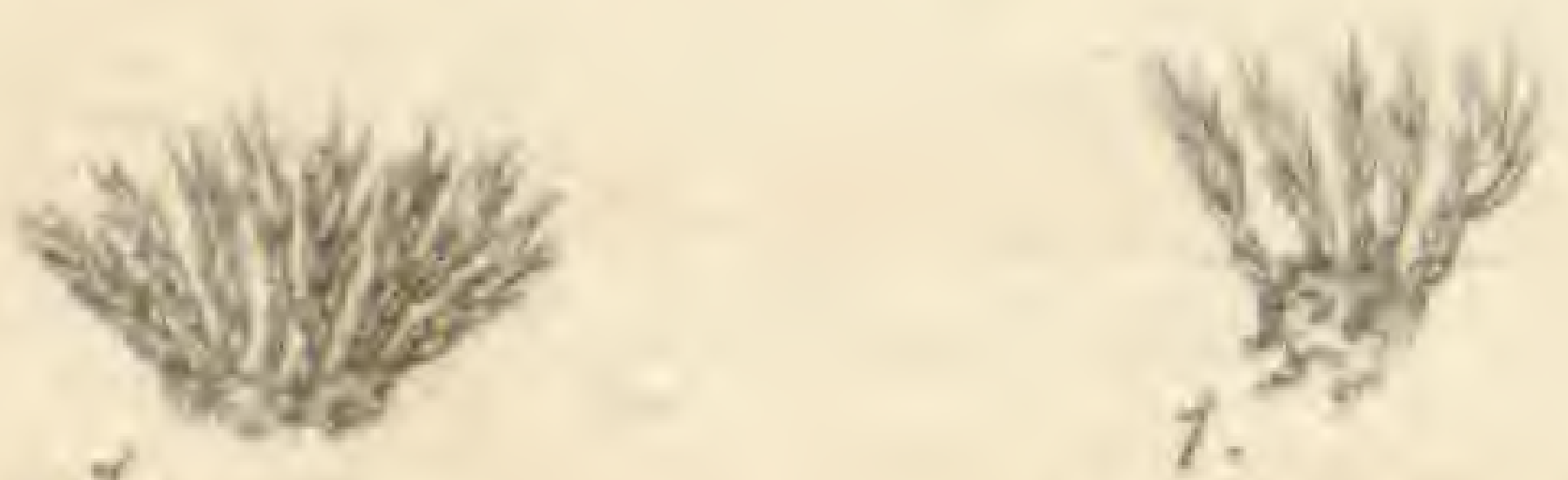

Wyy

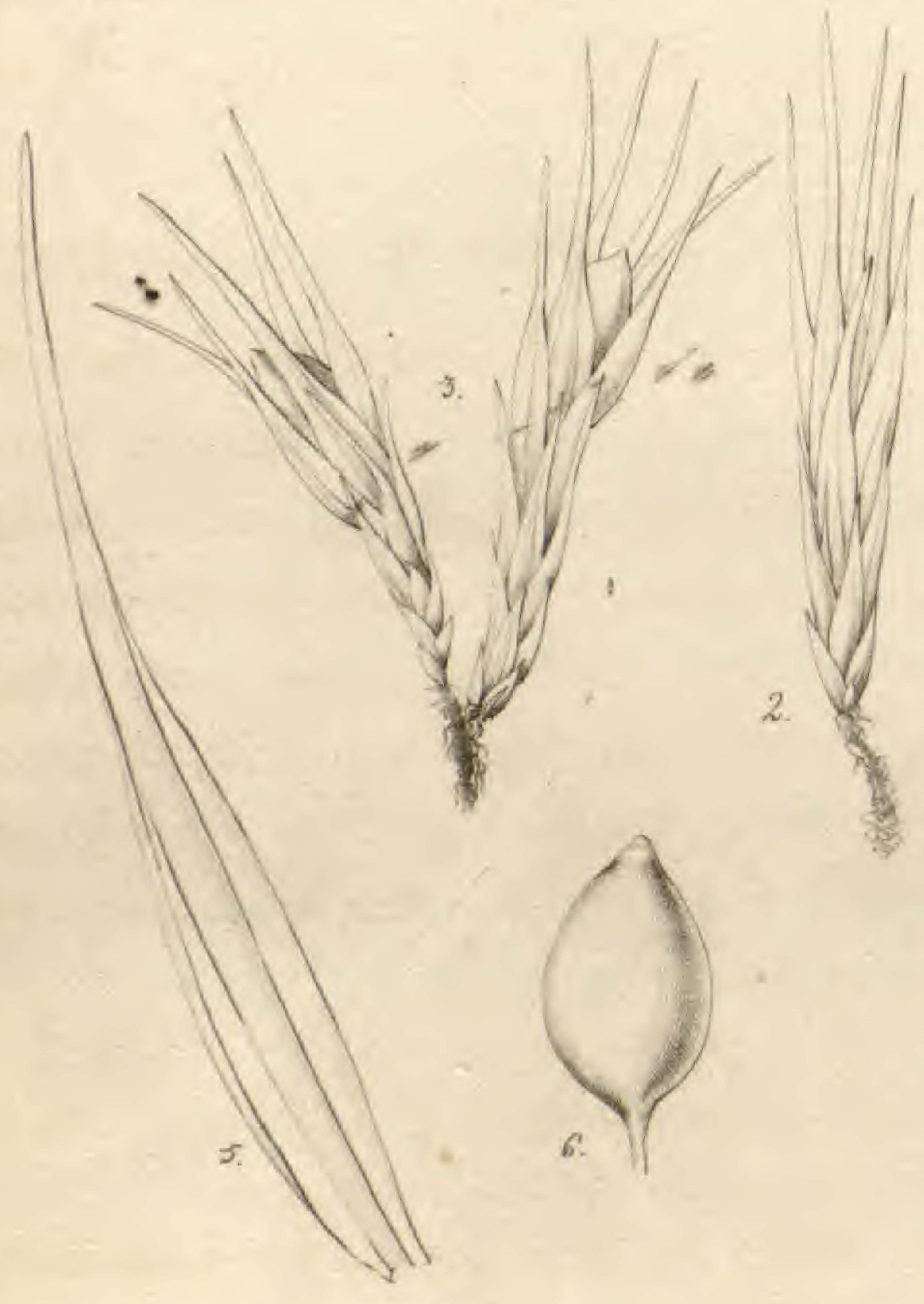

Phasam nervisum:

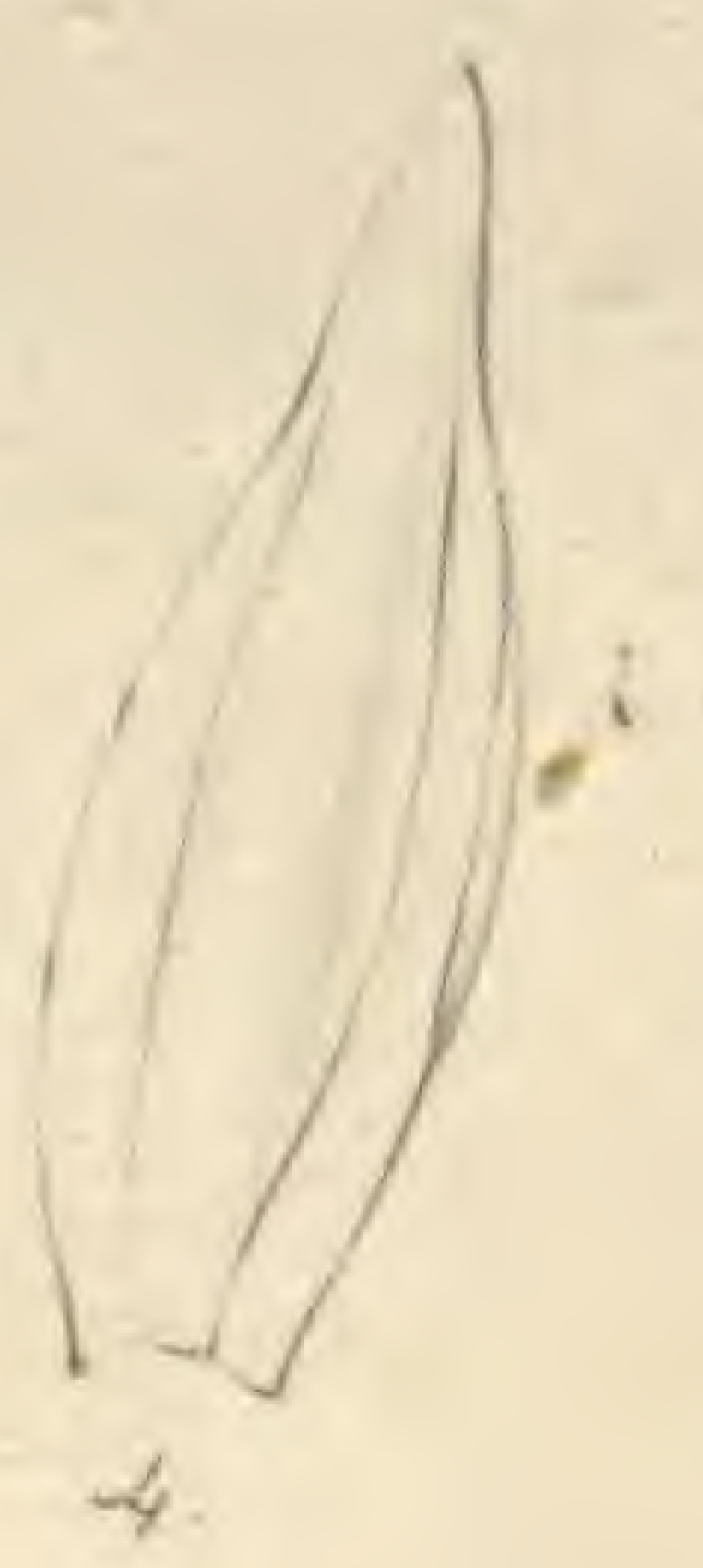

Elumande Sopt. 


\section{PHASCUM NERVOSUM.}

Phascum caule subsimplice breviusculo, foliis inferioribus ovatis subacuminatis, superioribus elliptico-lanceolatis longe acuminatis crassinervibus, seta subnulla, capsula immersa ovato-globosa acuminulata. ( $\mathrm{T}_{\mathrm{AB}}$. CV.)

$\mathrm{H}_{\mathrm{AB}}$. E promontorio Capitis Bonæ Spei. D. Menzies, 1791.

Caules cæspitosi, bi-trilineares, erecti, simplices vel ad basin dichotomi. Folia lutescente-viridia, erecta, inferiora ovata, parum concava, nervo latissimo in acumen breve desinente, superiora seu perichcetjalia sensim majora, elliptico-lanceolata, concava, nervo latissimo, ut in Dicrano flexuoso et ejus affinitatibus, fuscescente, in acumen longum angustum integerrimum extendente percursa. Foliorum sulstantia compacta. Seta vix ulla. Capsula foliis perichætialibus omnino obtecta, ovata, rufo-fusca, apice acuminulata.

Although at the first aspect this Phascum has much similarity to Ph. subulatum, yet when the leaves are more accurately ex * amined, they will be found not only to differ in shape, but remarkably also in the structure of the nerve, which in this plant is very broad. In this particular it approaches to the Ph.crassinervium of Schwaegrichen, from which it again differs in the leaves of the latter being as strongly reticulated as those of $P h$. serratum.

Fig. 1, tufts of plants, nat. size. Fig. 2, sterile plant; and Fig. 3, fertile ditto. Fig. 4, inferior leaf. Fig. 5, superior ditto. Fig. 6, capsule, $-m a g n$.

VoL. II. 


\section{ANICTANGIUM REPENS.}

Anictangium caule repente ramoso, ramis erectis clavatis, foliis ovato-rotundatis reticulatis acuminulatis enervibus, perichætialibus longe acuminatis diaphanis, seta subnulla, capsula cyathiformi, operculo conico-depresso. (ТАв. CVI.)

НАB. In plaga occidentali Novæ Hollandiæ. D. Mensies, 1791.

Caules laxe cæspitosi, repentes, flexuosi, foliis destituti, hic illic tomento ferrugineo obsiti, ramosi, ramis brevibus, erectis, clavæformibus. Folia flavo-viridia, horizontalia, concava, ovatorotundata, breviter acuminata, integerrima, omnino enervia, reticulata, areolis grandiúsculis, subquadratis. Perichetialia multo majora, magis erecta, ovato-rotundata, longe tenuiterque acuminata, enervia, flexuosa, scariosa, albida. Seta terminalis, brevissima. Capsula cyathiformis, fusca, margine subincrassata. Operculum conico-compressum. Calyptram non vidi. Semina magna, intense rufo-fusca.

This is a very remarkable moss, of which Mr. Menzies' specimens unfortunately possess no calyptra; yet I think there can be no doubt of its being an Anictangium. The texture of the foliage is, however, remarkably unlike that of any other species in the genus; the perichætial leaves differ from the cauline ones in being destitute of reticulation, and in being scarious and white; and what is still more worthy of observation in this plant, is the large size of the seeds, which far exceeds that of any moss I have yet met with.

Fig. 1, plants, nat. size. Fig. 2, single plant. Fig. 3, leaf. Fig. 4, portion of ditto, to show the reticulation. Fig.5, perichætial leaf. Fig. 6, portion of ditto, to show the reticulation. Fig. 7, capsule and perichætial leaf. Fig. 8, operculum. Fig.9, seeds,-magn. 
รab CVd.
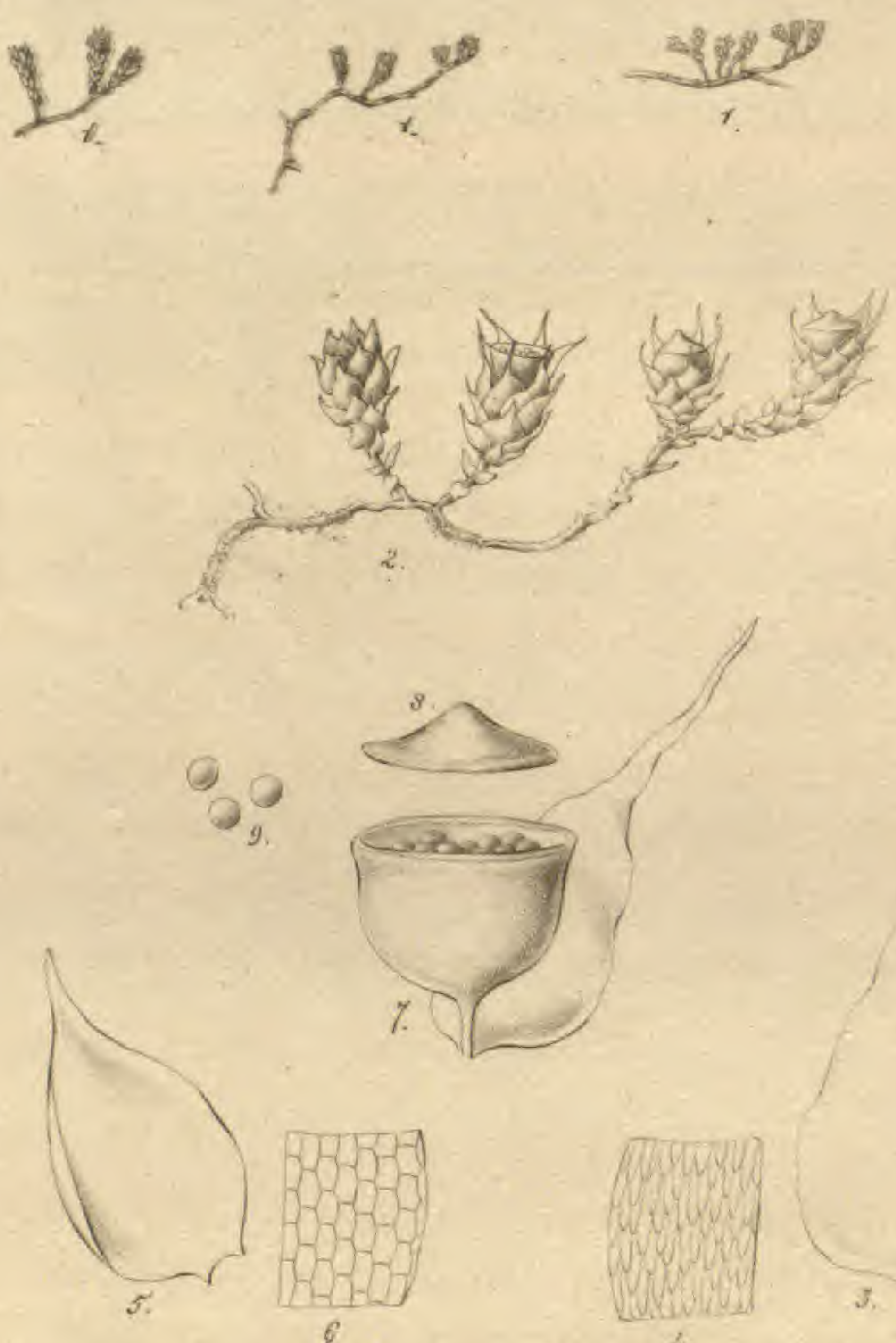

(2)
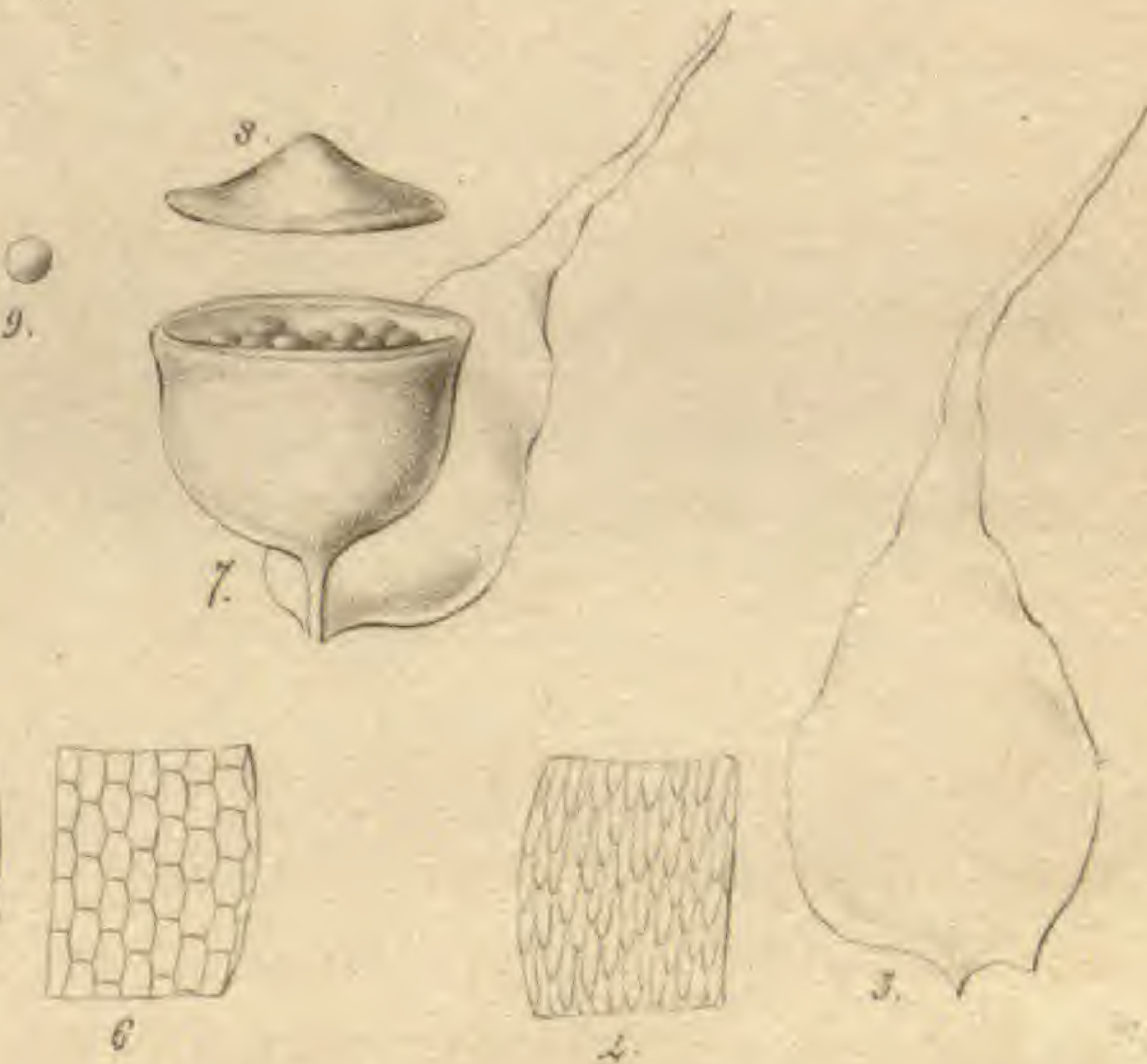

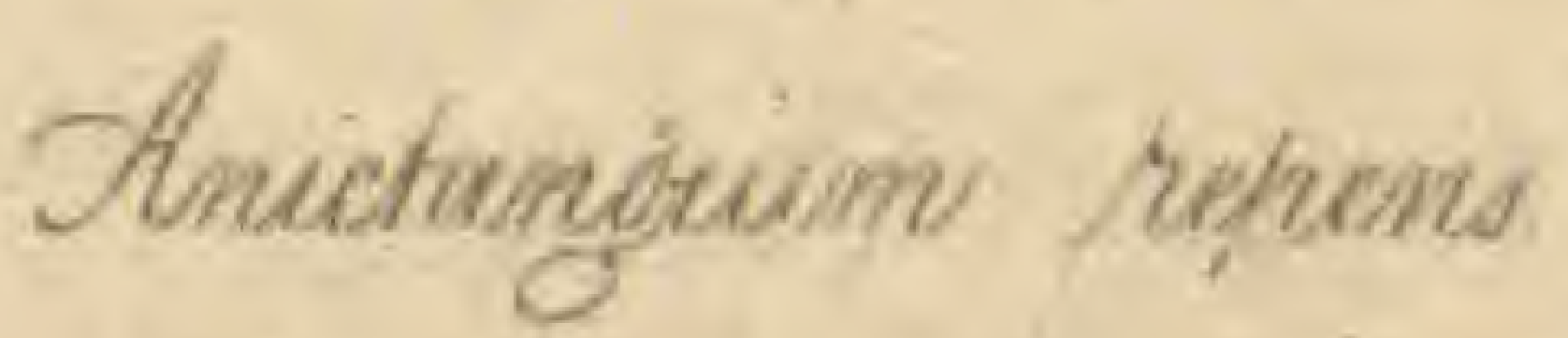

Gawnetis in:- 


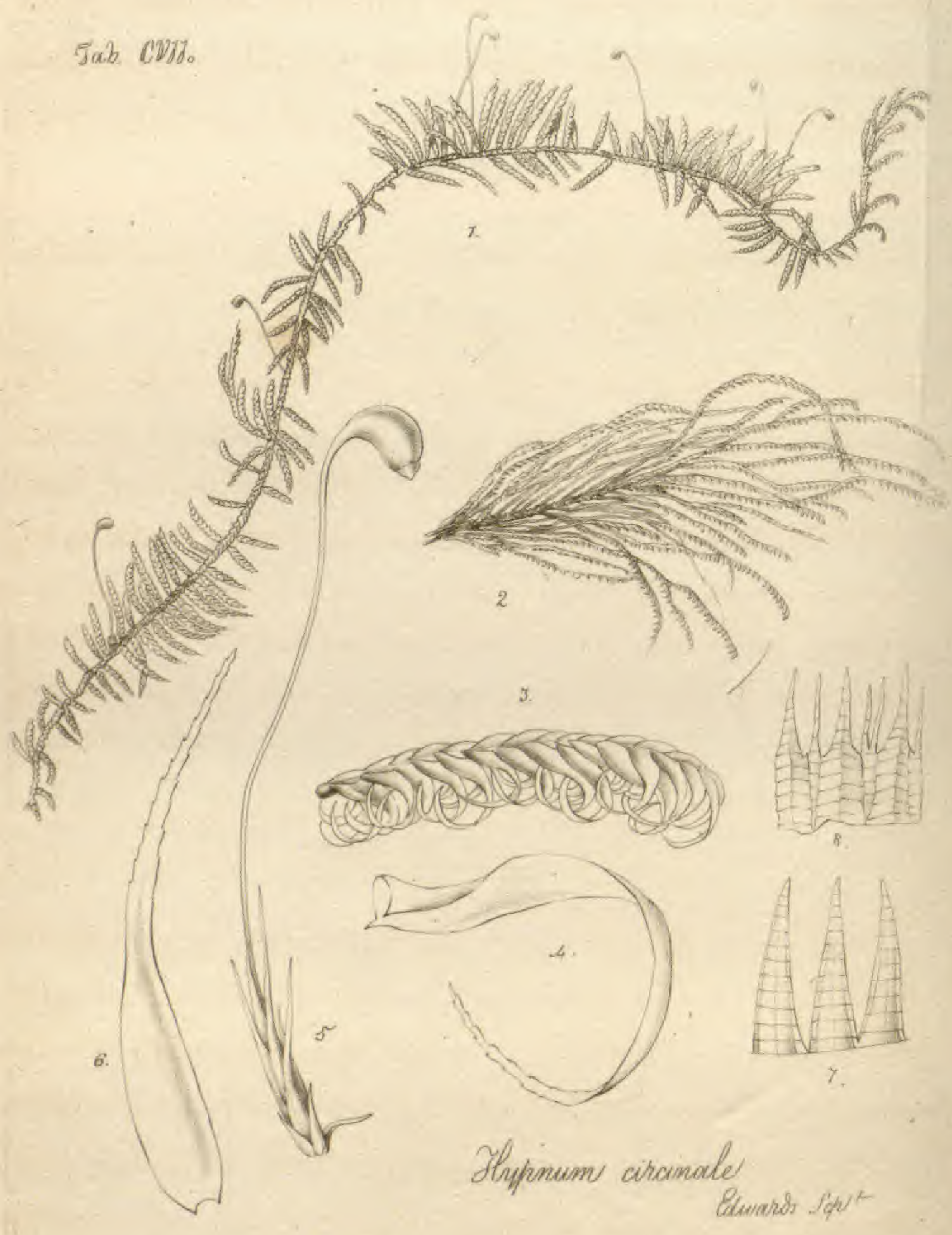




\section{HYPNUM CIRCINALE.}

Hypnum caule repente dense pinnatim ramoso, foliis lanceolato-subulatis subserratis secundis circinalibus enervibus, seta breviuscula, capsula ovata cernua, operculo conico." (TAB. CVII.)

HAB. Arboribus in plaga occidentali Americæ meridionalis. D. Menzies, 1793.

Planta valde polymorpha. Caulis repens, bi-triuncialis ad palmarem, flexuosus, ramosus, ramis numerosis alternis horizontaliter pinnatis, nunc brevibus vix semiuncialibus, nune biuncialibus, flexuosis. Folia lutescente-viridia, basi aurantia, secunda, lanceolata, longe-subulata, inferne concava, superne plana, apice subserrata, omnino enervia. Perichatialia erecta, magis serrata. Seta vix unciam longa, erecta, flexuosa, rufo-fusca. Capsula ovata, cernua, intense fusca. Peristomium flavum.

Among our British species of Hypna this approaches the nearest to H. cupressiforme; but in none of the numerous varieties of this plant are the leaves nearly so much incurved as in the present plant, nor is the capsule drooping or of the same figure. The H. imponens, judging from the figure in Hedwig's $S p$. Musc. t. 77, has much resemblance in the ramification and foliage, but then the capsule is quite erect, and the lid pointed.

Fig. 1 and 2, plants, nat. size. Fig. 3, portion of a branch. Fig.4, leaf. Fig.5, perichætium, fruitstalk, and capsule. Fig.6, perichætial leaf. Fig. 7, teeth of outer peristome. Fig. 8, portion of inner peristome,-magn. 


\section{HYPNUM ROBUSTUM.}

Hypnum caule erecto ramoso, foliis densissime imbricatis ovato-acuminatis falcato-secundis striatis transversim rugosis, apice subserrulatis basi binervibus, seta breviuscula, capsula ovato-oblonga cernua. (ТАB. CVIII.)

НАB. In plaga occidentali Americæ septentrionalis. D. Menzies, 1793.

Caulis crassus, ereetus, dichotome ramosus, ramis nunc iterum divisis. Folia aureo-flavescentia, subnitentia, densissime imbricata, ovato-acuminata, falcato-secunda, subconcava, striata, transversim undulata, apice subserrulată, basi breviter binervia, raro uninervia. Seta sesquiuncialis, rufa, glabra. Capsula ovato-oblonga, cernua, fusca.

At first I was disposed, with $\mathrm{Mr}$. Menzies, to consider this plant as merely a variety of $\mathrm{H}$. rugulosum of Weber and Mohr; but upon further investigation $\mathrm{I}$ am induced to publish it as a distinct species, upon the grounds of its much larger size, its erect mode of growth, its very robust habit, and its thickly crowded, striated, and, in almostwery instance, two-nerved leaves.

Fig. 1, sterile plant; and Fig. 2, fertile plant, nat. size. Fig. 3, portion of a branch. Fig. 4, 4, leaves.-magn. 
Fab CVIII.

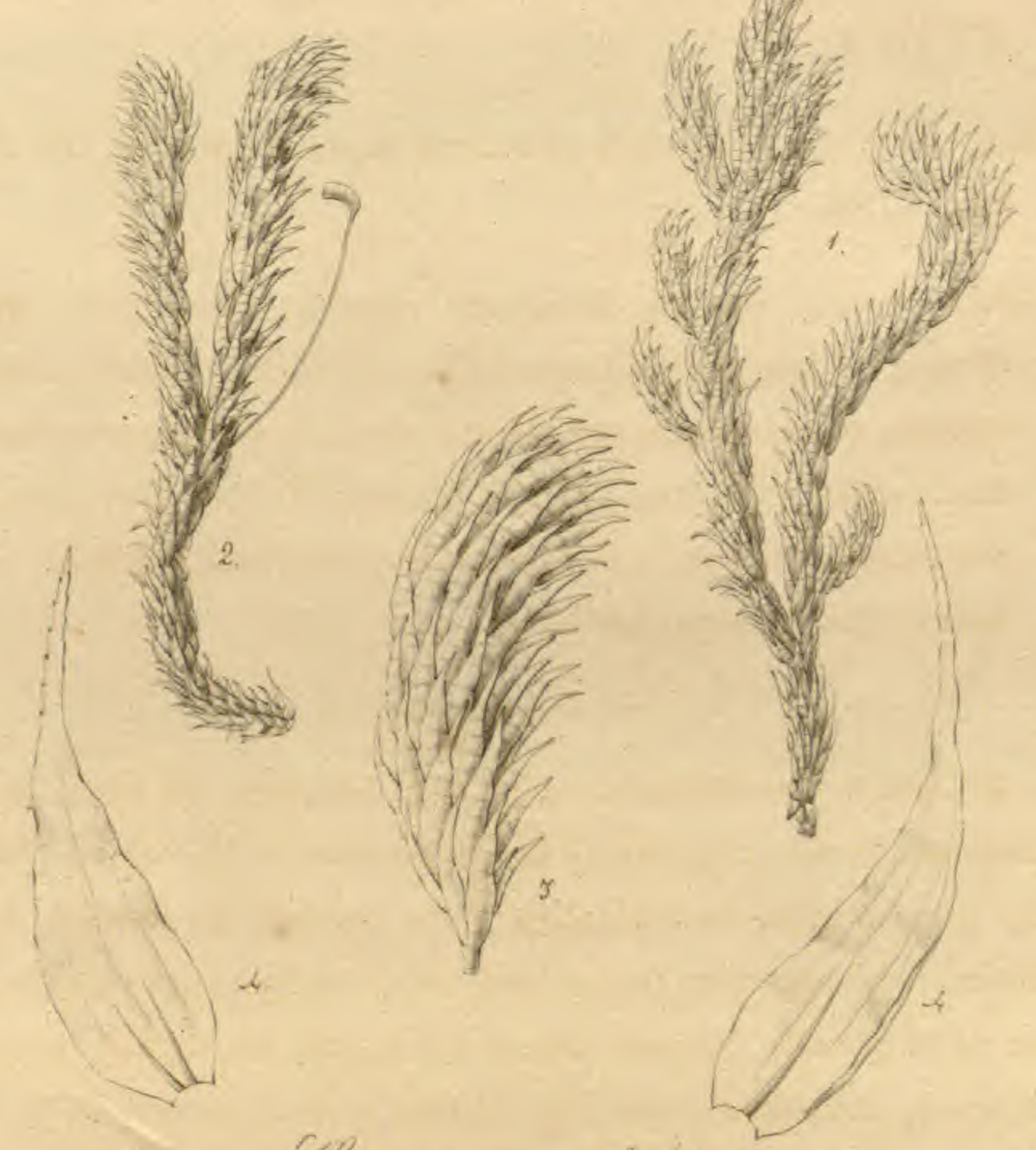

SThpruenum mibustum Gevourds dipt. 
รab c7x.

is

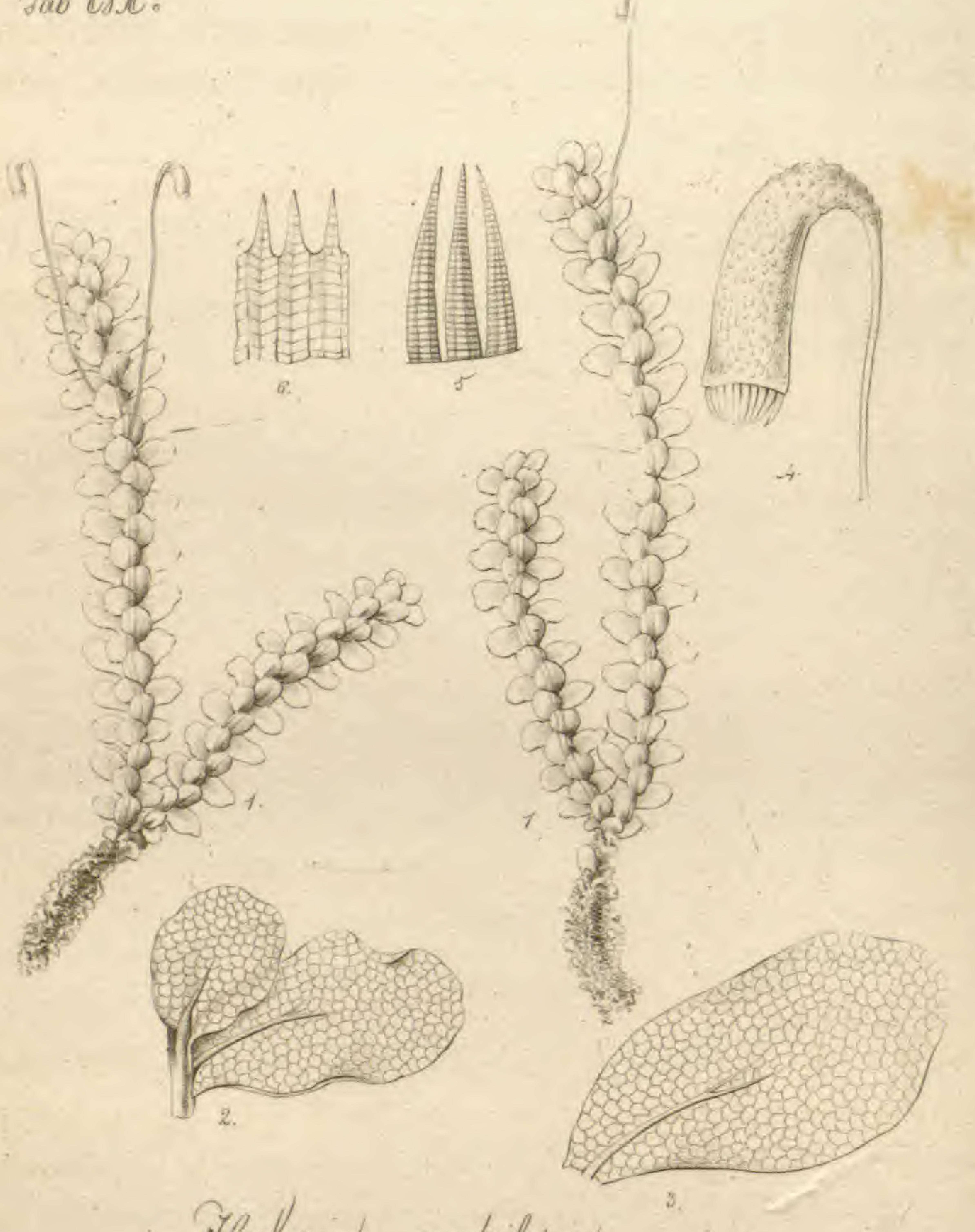

Shlostherial quadriforional

$$
\text { Eluratuds Sent }
$$




\section{HOOKERIA QUADRIFARIA.}

Hookeria caule erecto subramoso, foliis quadrifariis reticulatis medio uninervibus, lateralibus distichis horizontalibus verticalibus obovatis, intermediis subrotundatis erectis appressis, capsula subcylindracea pendula. (ТАв. CIX.)

Hookeria quadrifaria. Smith in Linn. Trans. v. 9. p. 277 . t. 23 . f. 1.

HAB. In sinu Dusky bay apud Novam Zeelandiam. D. Menzies, 1791 .

Caules digitales, erecti, flexuosi, simplices vel subramosi, basi radicibus tomentosis fuscis obsiti. Folia fusco-viridia, quadrifariam inserta, laxe imbricata ; lateralia majora, disticha, verticalia, horizontaliter patentia, obovata; intermedia utrinque adpressa, lateralibus duplo minora, erecta, obovato-rotundata; omnia integerrima, succulenta, reticulata, areolis rotundatis, uninervia, nervo rubro, medio evanescente, sæpe bifurco. Seta uncialis, rufo-fusca, lævis. Capsula cylindracea, pendula, intense fusca, scabra, basi præcipue. Perist. ext. e dentibus 16 rufo-flavis, transversim striatis, medio linea longitudinali pellucida : int. e membrana flava reticulata apice in laciniis 16 brevibus subulatis integerrimis divisa.

Few, I believe, would hesitate in pronouncing this plant to belong to the same genus as Hookeria lucens; yet I cannot but regret that, like Sir James Smith, I have never had the opportunity of examining the calyptra, and am therefore obliged to form my decision upon the habit of the species alone. It is remarkable for the quadrifarious disposition of the leaves, and for the intermediate ones being both smaller and rounder than the lateral ones to such a degree, that they might be mistaken for stipules, were it not that these appendages are, as well in Mosses as Jungermannix, confined to one side of the plant.

Fig. 1, 1, plants, nat. size. Fig. 2, lateral and intermediate leaf. Fig. 3, lateral ditto. Fig. 4, capsule. Fig. 5, teeth of ext. peristome. Fig. 6, portion of inner ditto,-magn. 


\section{HYPNUM FLEXILE.}

Hypnum caule elongato flexuoso ramoso, foliis imbricatis late-ovatis valde concavis obtusis integerrimis enervibus, capsula ovato-cylindracea erecta. (ТАB. CX.) Hypnum flexile. Swarts Fl. Ind. Occ. p. 1830. Leskea flexilis. Hedw. Sp. Musc. p. 234. t. 58. Schwaegr. Suppl. p. 168.

Hookeria flexilis. Smith in Linn. Trans, v. 9. p. 281.

$\mathrm{H}_{\mathrm{AB}}$. In montibus summis Jamaicæ australis. Swartz. In sinu Dusky bay dicto apud Novam Zeelandiam. D. Menzies, 1791.

Caules elongati, decumbentes vel e ramis arborum pendentes, flexuosi, ramosi, ramis brevibus subsimplicibus cylindraceis apice acutiusculis. Folia nitida, flavo-viridia, subarcte imbricata, erecto-patentia, subundulata, late ovata, valde concava, margine integerrima, apice obtusa, omnino enervia. Perichatialia cylindracea, acuta. Seta uncialis. Capsula erecta, ovato-cylindracea. Peristomium Hypni.

Sir James Smith considers the capsule of this moss as cernuous; and so it is in some degree from the inflexion of the fruitstalk in a dry state, but when moist it will be found to be erect. From the same learned botanist I also beg leave to differ respecting the genus of this plant. I must however confess, that I have not seen its calyptra, and that my opinion is therefore formed merely from its habit, which approaches in many points that of Leskea ericoides. (TAB. XXVIII.)

Fig. 1, plant, nat. size. Fig. 2, branch, with fructification. Fig. 3, leaf. Fig. 4 and 5, perichætial leaves. Fig. 6, teeth of outer peristome. Fig. 7, portion of inner ditto,-magn. 


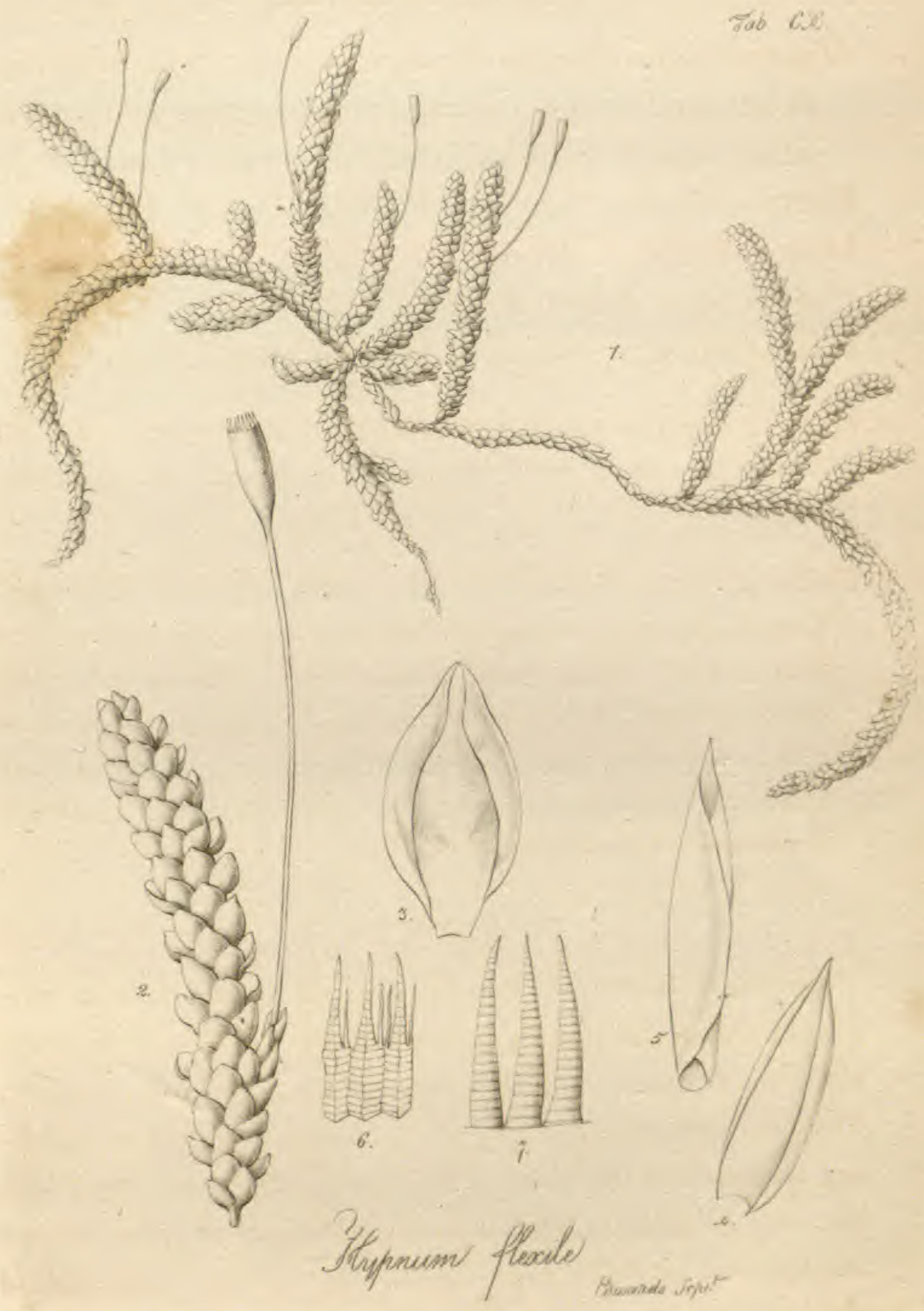


giab. Callo.

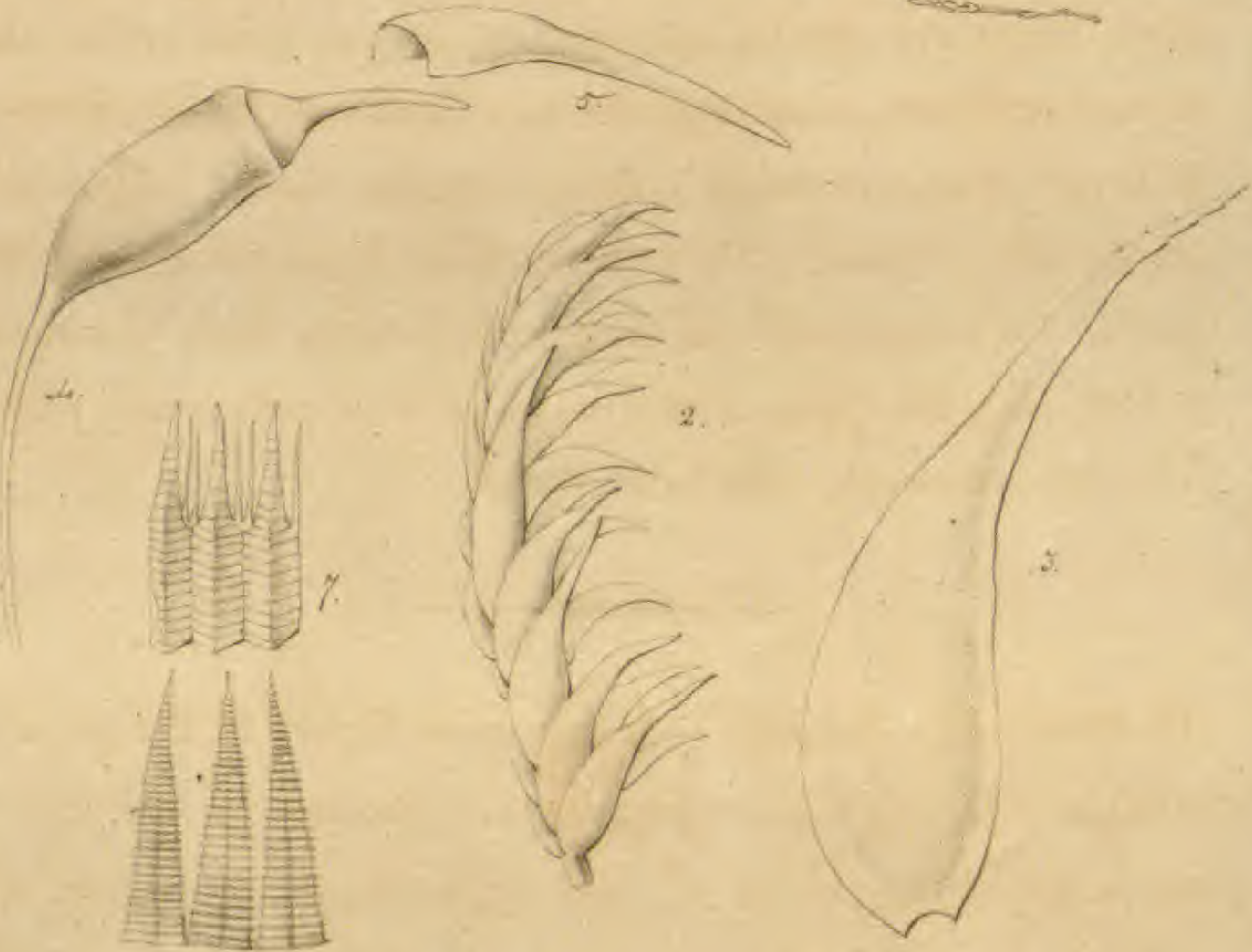

6.

Thpmum temuirostio.

Evars loget 1 


\section{Muscr Exoт г I.-Menziesiani.}

\section{HYPNUM TENUIROSTRE.}

Hypnum caule repente, ramis erectis, foliis falcato-secundis ovatis longe acuminatis subintegerrimis enervibus, capsula oblongo-ovata cernua, operculo longirostrato. (TAв. CXI.)

HAB. In sinu Dusky bay dicto apud Novam Zeelandiam. D. Menzies, 1791.

Caulis repens, flexuosus, filiformis, ramosus, foliis plerumque destitutus, ramis erectis iterum sæpissime divisis. Folia fuscoviridia, nitentia, undique inserta, falcato-secunda, ovata, concava, longe acuminata, integerrima, vel sub lente apice minutissime serrulata, omnino enervia. Seta subuncialis, flavo-rufescens. Capsula ovato-oblonga, cernua, fusca. Operculum rostro longo tenui. Calyptra pallide fusco-flavescens, dimidiata. Peristomii externi dentes 16 , intense flavi, transversim striati, margine quasi denticulati ; interni membrana plicata, 16-fida, segmentis ciliis interpositis.

H. tenuirostre belongs to a numerous family of the genus remarkable in having falcate leaves; and though the habit of this plant is very unlike that of $H$. cupressiforme, yet the leaves, when magnified, bear no inconsiderable resemblance to some of its varieties, from all which it may be at once distinguished by the length of the operculum.

Fig. 1, plants, nat. size. Fig. 2, portion of a branch. Fig. 3, leaf. Fig. 4, capsule. Fig. 5, calyptra. Fig. 6, teeth of outer peristome. Fig. 7, portion of inner ditto.-magn. 


\section{HYPNUM ARBUSCULA.}

Hypnum caule erecto bipinnatim ramoso, foliis undique imbricatis ovatis concavis integerrimis basi obsolete binervibus, seta brevi, capsula erecta ovata. (TAB. CXII.)

Hookeria Arbuscula. Smith in Linn. Trans. v. 9. p. 280 . t. 23.

HaB. In sinu Dusky bay dicto apud Novam Zeelandiam. D. Menzies, 1791.

Caulis palmaris et ultra, basi repens, tomento fusco-ferrugineo obsitus, dein erectus flexuosus rigidus, inferne simplex, foliis parvis tectus, superne pinnatus, ramis iterum divisis, inferioribus longioribus, omnibus horizontaliter patentibus. Folia tescente-viridia, undique imbricata, erecto-patentia, nitida, ovata, concava, margine omnino integerrima, basi obsoletissime binervia. Perichetialia lanceolato-acuminata, enervia, recurva. Setce 3 -lineares. Capsula erecta, rufo-fusca. Peristomium ut in Hypno, dentibus flavo-fulvis, arete transversim striatis.

Not being so fortunate as to possess the calyptra of this handsome moss, I dare not venture to follow Sir J.E. Smith in making it a Hookeria, with which genus it does not to me appear to have much natural affinity. It has a tree-like mode of growth, very similar to Neckera dendroides, N. planifolia, Leskea concinna, Hypnum neckerioides, \&c. differing, however, from all these in the foliage and fructification. In its leaves and capsules it borders upon $H$. flexile. ('ТАв. CX.)

Fig. 1, plant, nat. size. Fig. 2, portion of a branch and fructification. Fig. 3, leaf. Fig. 4, perichætial ditto. Fig. 5, teeth of outer peristome. Fig. 6, portion of inner ditto.-magn. 


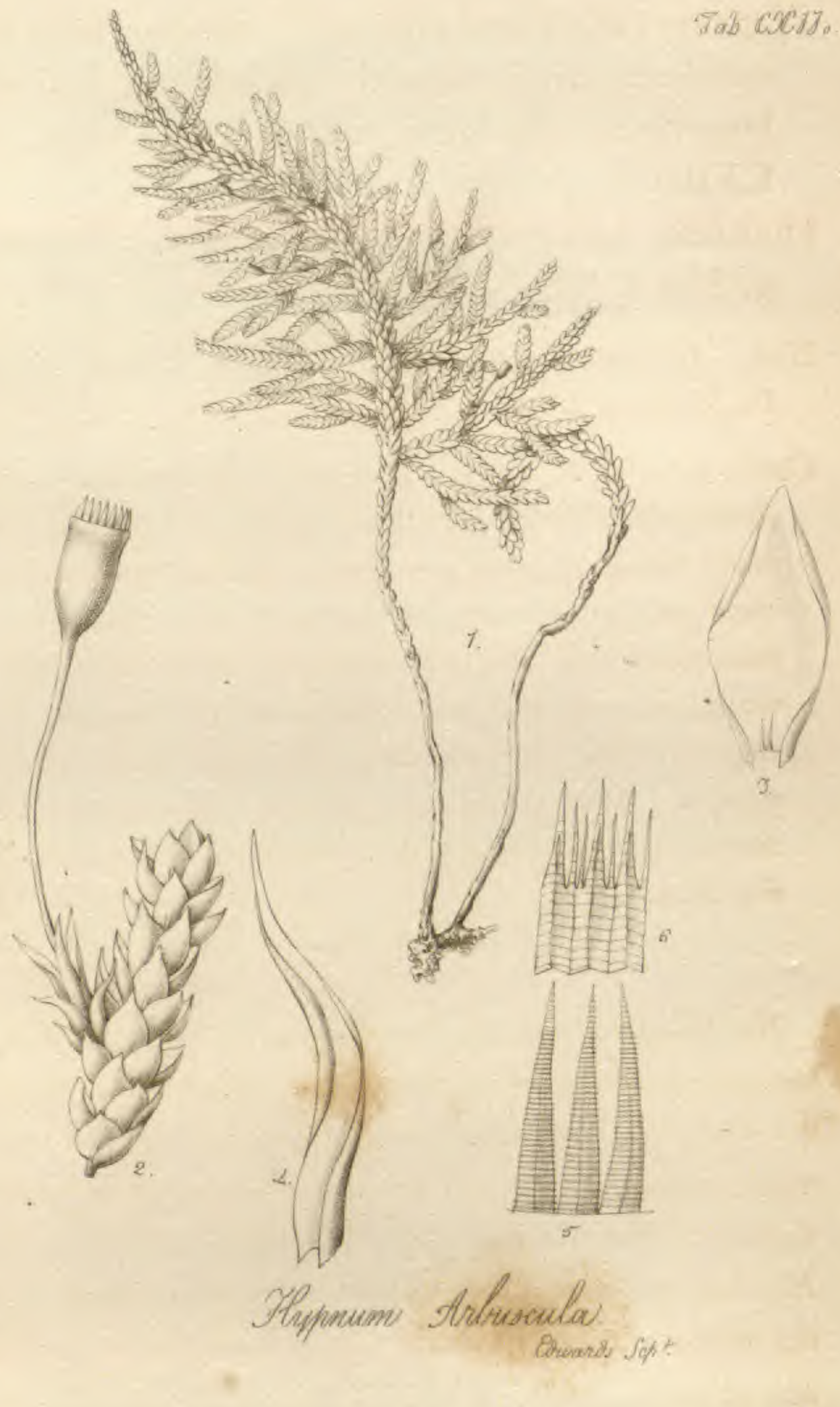




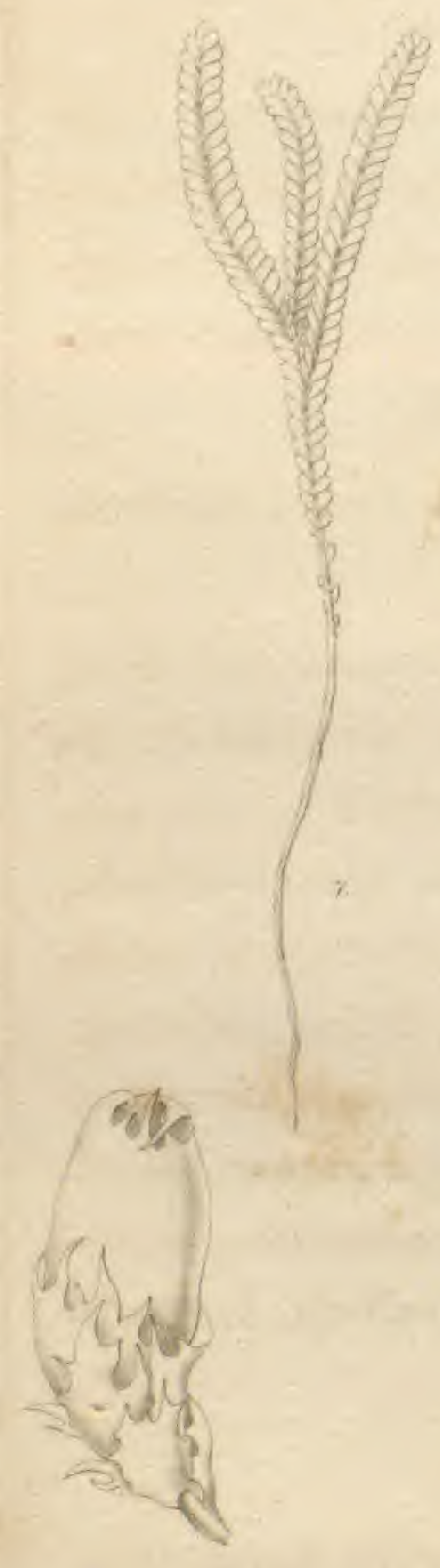

Tab. CXozd\%
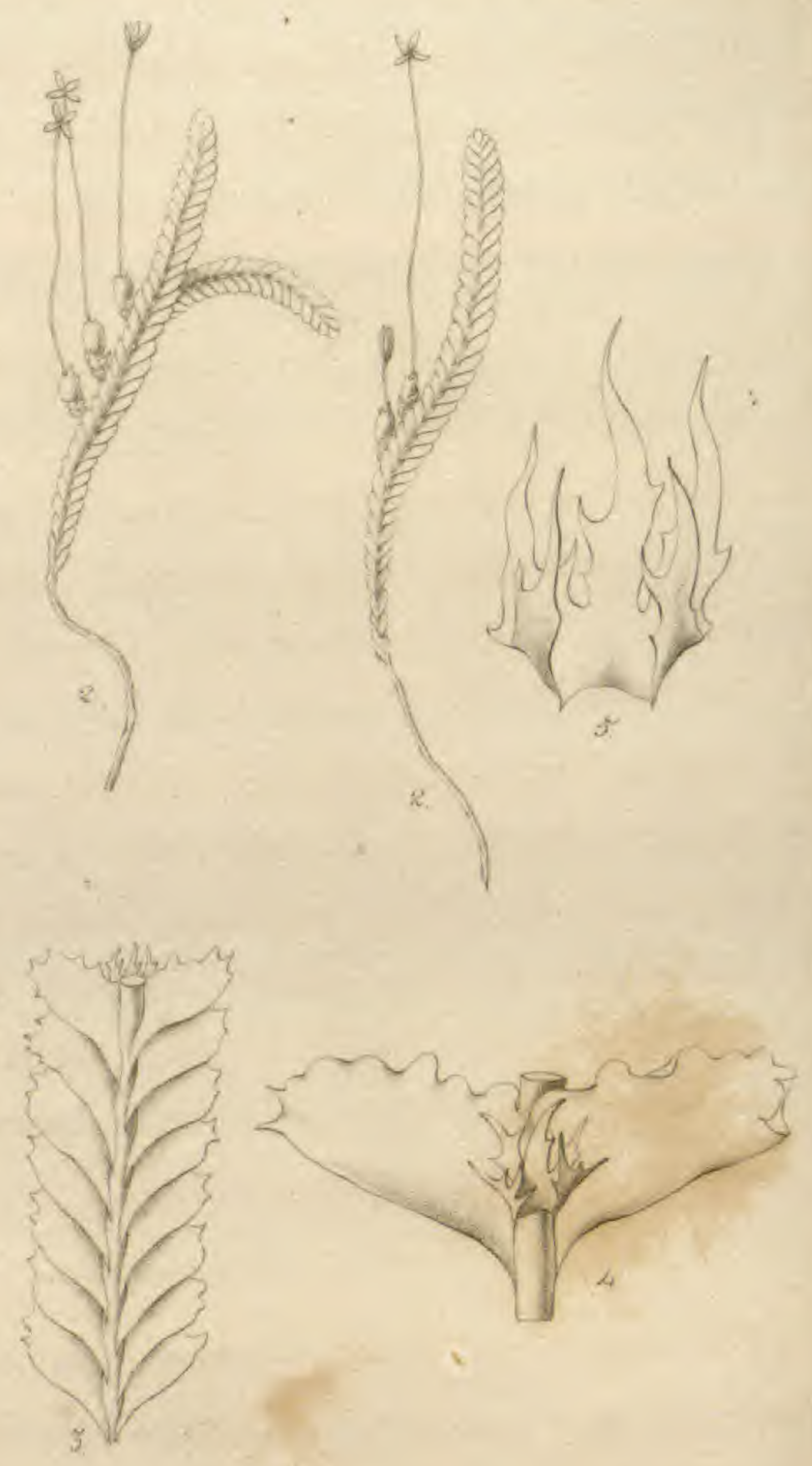

fundermanimex Anuesal Edaremonds Sopt 


\section{JUNGERMANNIA SINUOSA.}

Jungermannia caule elongato erecto subramoso, foliis distichis horizontalibus oblongis decurrentibus bidentatis margine superiore undulata, stipulis 5-fidis segmentis laciniatis, calyce laterali ex inferiore parte caulis ovato ore laciniato.

(TAB. CXIII.)

$\mathrm{H}_{\mathrm{AB}}$. In sinu Dusky bay dicto apud Novam Zeelandiam. D. Menzies, 1791.

Caules 3-4-pollicares, erecti, simplices vel per innovationes divisi, fusco-nigricantes, inferne denudati. Folia bifaria, erecta, disticha, verticalia, horizontaliter patentia, arcte imbricata, pallide fusco-viridia, oblonga, basi decurrentia, apice bidentata, margine superiore insigniter undulata et subrevoluta, areolis minutis reticulata. Perichcetialia minora, laciniato-dentata. Stipula quinquefidx, segmentis longis, attenuatis, lateralibus recurvis, marginibus laciniato-dentatis. Caly $x$ in ramulis propriis brevissimis ex parte inferiore caulis egredientibus, lateralis, ovatus, ore coarctato, laciniato, laciniis inflexis, Seta subuncialis, Capsula oblongo-ovata.

The singularly undulate superior margins of the leaves, their bidentate apices, and the form of the stipules, will readily distinguish this species from J. horizontalis, with which it has considerable natural affinity. It is remarkable for its lengthened stalk, which is bare of leaves in its lower half.

Fig. 1, sterile, and Fig. 2, 2, fertile plants, nat. size. Fig.3, portion of a stem and leaves, upper side. Fig. 4, leaves and stipules, lower side. Fig. 5, stipules. Fig. 6, calyx and perichæetium.-magn.

Vol. II. 
Musci Exотгі.-Menziesiani.

\section{JUNGERMANNIA PINNATIFOLIA.}

Jungermannia caule erecto ramoso, foliis dense bifariam imbricatis ciliatis conduplicatis apice bilobis, lobis inciso-pinnatis, calyce terminali oblongo quadrifido, segmentis inciso-pinnatis ciliatis. (TАB. CXIV.)

Hab. In sinu Dusky bay dicto apud Novam Zeelandiam. D. Menzies, 1791.

Caules 3-pollicares, erecti, flexuosi, dichotome ramosi. Foliu exacte disticha, dense bifariam imbricata, horizontalia, oblonga, per totam marginem ciliata, flavo-viridia, areolis parvis rotundatis reticulata, conduplicata, apice biloba, lobis incisopinnatis, pinnis ovatis acutis. Perichaetialia erecta. Calyx terminalis oblongus quadrifidus, segmentis oblongis, inciso-pinnatis, ciliato-dentatis. Corolla ovata, parte inferiore calyci coadunata, versus apicem corpora pistilliformia gerens. Seta calyce vix duplo longior. Capsula oblonga 4-valvis, rufo-fusca, segmentis linearibus.

This is the third Menziesian Jungermannia with inciso-pinnated extremities to the leaves; from the two already figured, the present essentially differs in the absence of the stipules as well as in the general structure of the leaves, whichmost rese mbles that of $J$. densifolia and our $J$. allicans, as indeed does the whole habit of the plant. A remarkable circumstance may be observed in the corolla, which in the lower half is united with the calyx, while the upper half is free.

Fig. 1, 1, plants, nat. size. Fig. 2, leaf. Fig. 3, the same spread open. Fig. 4, apex of ditto. Fig. 5, calyx. Fig. 6, corolla, with fruitstalk and capsule.-magn.

* The two others are J. lamellata (TAB. XLIX.) and J. appendiculata (TAB. XV.). 


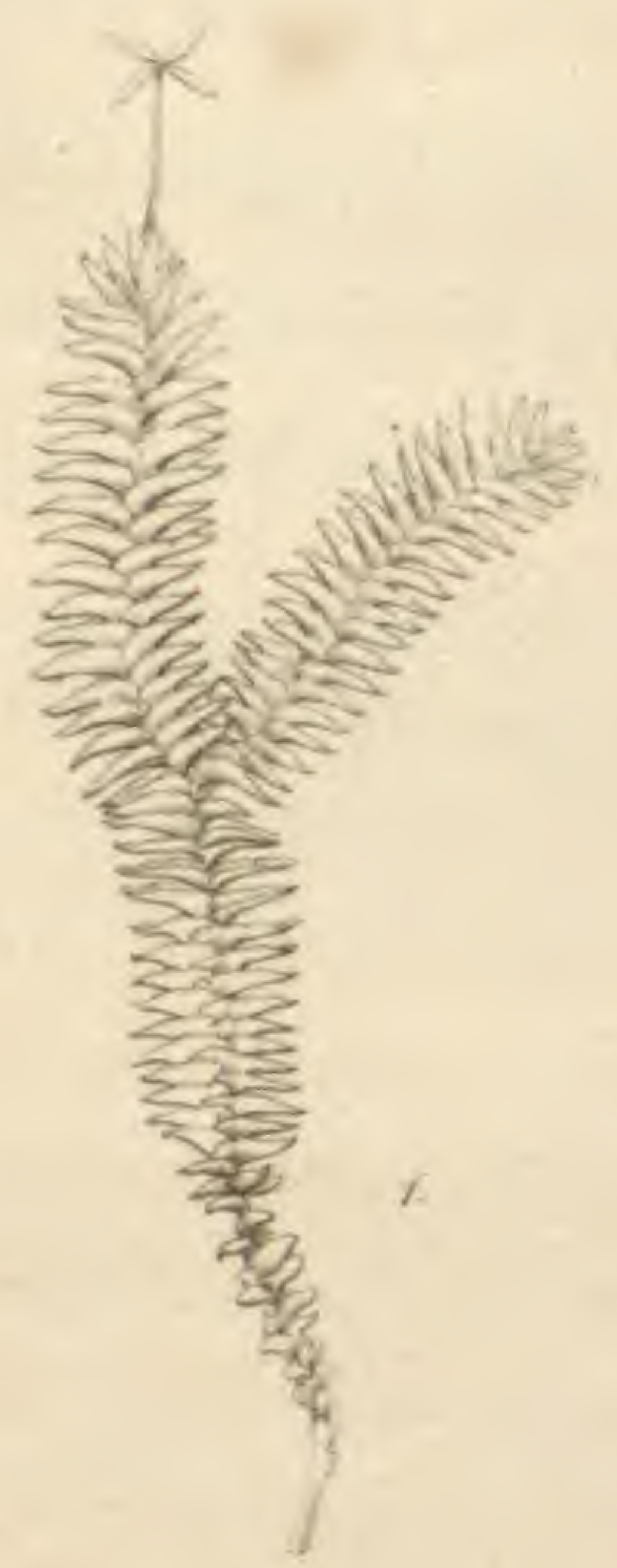

Jab. eXcros.
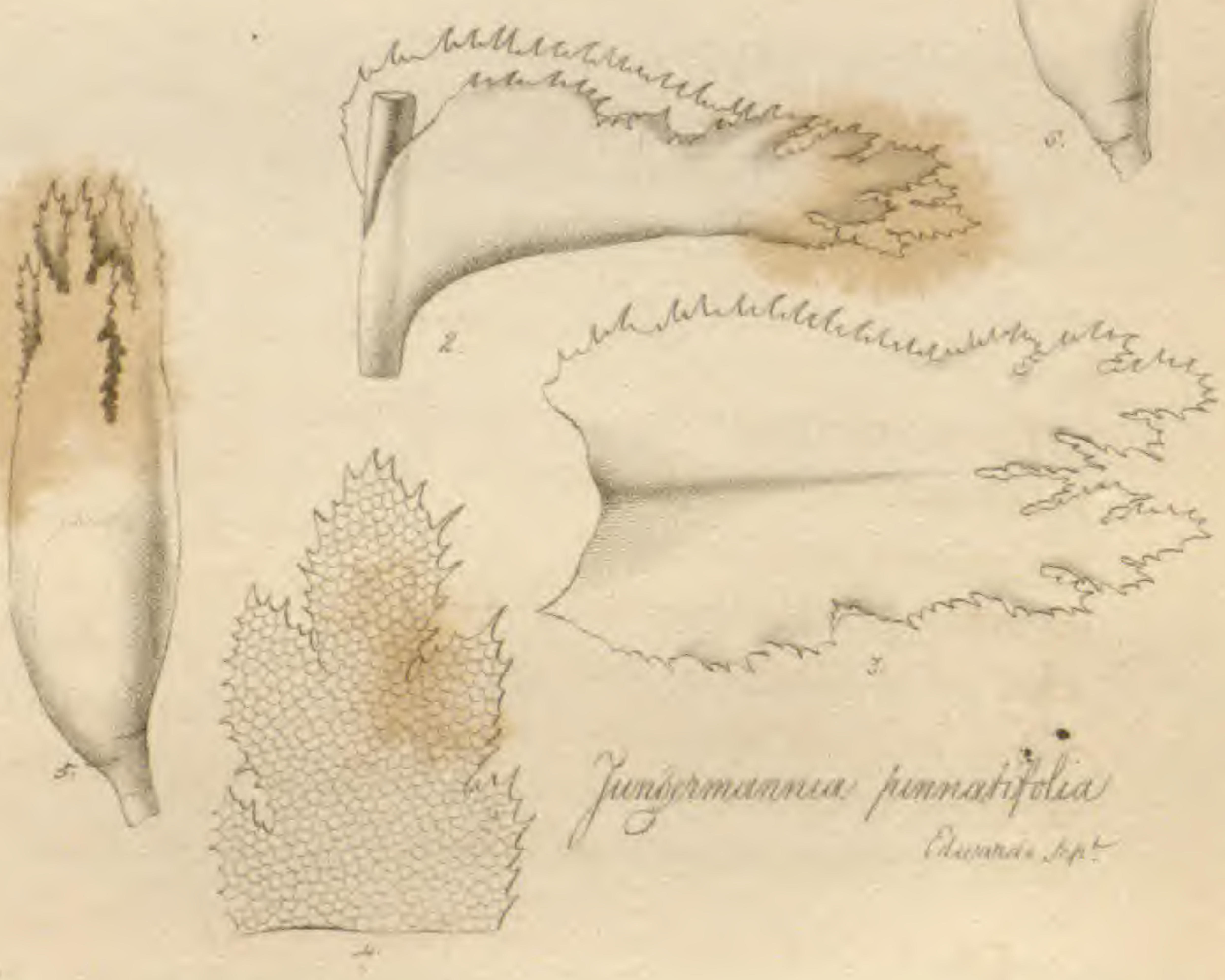


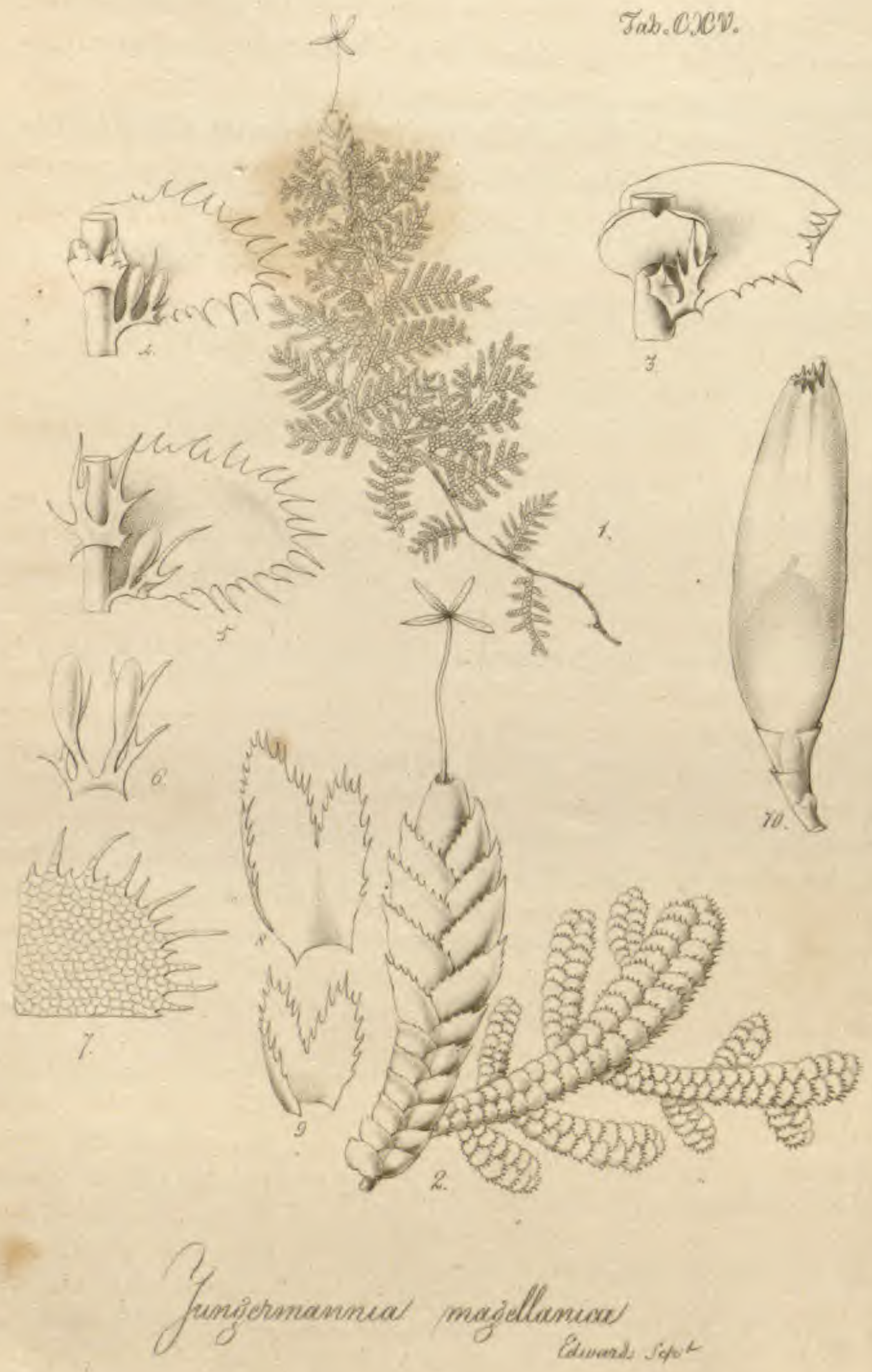


JUNGERMANNIA MAGELLANICA.

Jungermannia caule repente tripinnatim ramoso, foliis horizontalibus inæqualiter bilobis conduplicatis ciliato-spinosis, lobis ovato-rotundatis, lobulis bifidis segmentis oblongis laciniatis uno sæpissime claviformisaccato, stipulis lato-ovatis emarginatis margine recurvis (ramulorum bifidis laciniatis rarius claviformibus), calyce oblongo, ore dentato. ( $\mathrm{T}_{\mathrm{AB}} \mathrm{CXV}$.)

J. Magellanica. Lam. Encycl. Bot. v. 3. p. 28. Schwaegr. Hist. Muse. Hep. Prodr. p. 14. t. 1.

J. elegans. Rich. MSS.

$\mathrm{H}_{\mathrm{AB}}$. In Freto Magellanico. Commerson. In Staten Land prope Cape Horn. D. Menzies, 1787.

Caules 3-4-pollicares, repentes, flexuosi, tripinnatim divisi, ramulis ultimis brevibus. Folia intense purpureo-fusca, arcte imbricata, horizontalia, disticha, convexa, inæqualiter biloba, ciliato-spinosa ; lolis conduplicatis; superioribus multo majoribus, caulinis subintegerrimis; inferioribus minutis, oblongis, bifidis, segmentis caulium plerumque planis, laciniatis, ramorum uno, et sæpe duobus, claviformi-saceato, setigero. Perichalialia prægrandia, pallide fusca, calycem arcte cingentia et fere obtegentia, late ovata, subæqualiter biloba, margine tenuissime ciliata. Stipula forma maxime variabiles; caulince late ovatæ apice emarginatæ, marginibus integerrimis, superne reflexis ; ramorum ovato-quadratæ, semibifidæ, segmentis marginibus reflexis denticulatis; ramulorum bifidæ, segmentis longis acuminatis, laciniatis, raro claviformi-saceatis (fig.6.). Caly $x$ terminalis lateralisque, oblongus, ore dentato.

It is difficult, if not impossible, in a plant whose leaves and stipules vary so much in different parts of the same individual as in the present instance, to prevent the specific character from running to an apparently unreasonable length. Many of the leaves have indeed the greatest affinity to those of $J$. palpelrifolin, already figured in this work, (TAB. LXXI.) while the stipules of the two plants have no resemblance to one another, and the ramification of this is remarkably close and compact, and its fructification quite peculiar. A more beantiful object for the microscope can hardly be imagined than the present species, particularly the ultimate branches where the leaves are thickly crowded and most exquisitely fringed at the margins. The size of the perichætial leaves is worthy of observation.

Fig. 1, plant, nat. size. Fig. 2, portion of a plant with fructification. Fig. 3, stem leaf and stipule. Fig. 4, leaf from a branch with stipule. Fig. 5, leaf from an ultimate branch with stipule. Fig.6, stipule with its claviform appendages. Fig. 7, portion of a leaf. Fig. 8 and 9, perichætial leaves. Fig. 10, calyx.-magn. 


\section{JUNGERMANNIA LANATA.}

Jungermannia caule erecto compresso pinnatim ramoso, foliis bifariis horizontalibus inæqualiter bilobis, lobis conduplieatis stipulisque ciliato-multifidis, calyce oblongo, foliis perichætialibus oblongis ciliato-multifidis obtecto.

(TAв. CXVI.)

$\mathrm{H}_{\mathrm{AB}}$, In sinu Dusky bay dicto apud Novam Zeelandiam. D. Menzies, 1791 ,

Caulis erectus, compressus, pinnatim ramosus, ramis distantibus, subhorizontaliter patentibus, longiusculis, non raro ramis brevibus iterum pinnatis. Folia densissime imbricata, disticha, horizontalia, pallide glauco-viridia, inæqualiter biloba, lobis conduplicatis ciliato-multifidis, eiliis longis divaricatis articulatis; substantia tenuis, areolis oblongis magnis reticulata. Stipula subquadratæ ciliato-multifidæ. Calyx plerumque axillaris, oblongo-ovatus, subcarnosus, foliis perichætialibus vel squamulis angustis laciniatis obtectus. Seta biuncialis. Capsula ovata intense fusca, quadrivalvis.

The broad compressed stems and branches, taken in conjunct $\mathrm{n}$ with the leaves of this plant, its more crowded foliage, together with the much less degree of ramification, indicate to a casual observer a very striking difference from $J$. tomentella ; but when the leaves and stipules, and even the parts of fructification, come to be more carefully examined, a specific character can hardly be found:-in the subject of the present plate they are certainly less deeply cut into capillary or ciliary segments, but in other respects the two plants are precisely alike.

Fig. 1, sterile, and Fig. 2, fertile plant, nat. size. Fig.3, leaf. Fig. 4, stipule. Fig. 5, calyx. Fig. 6, perichætial leaf.-magn. 


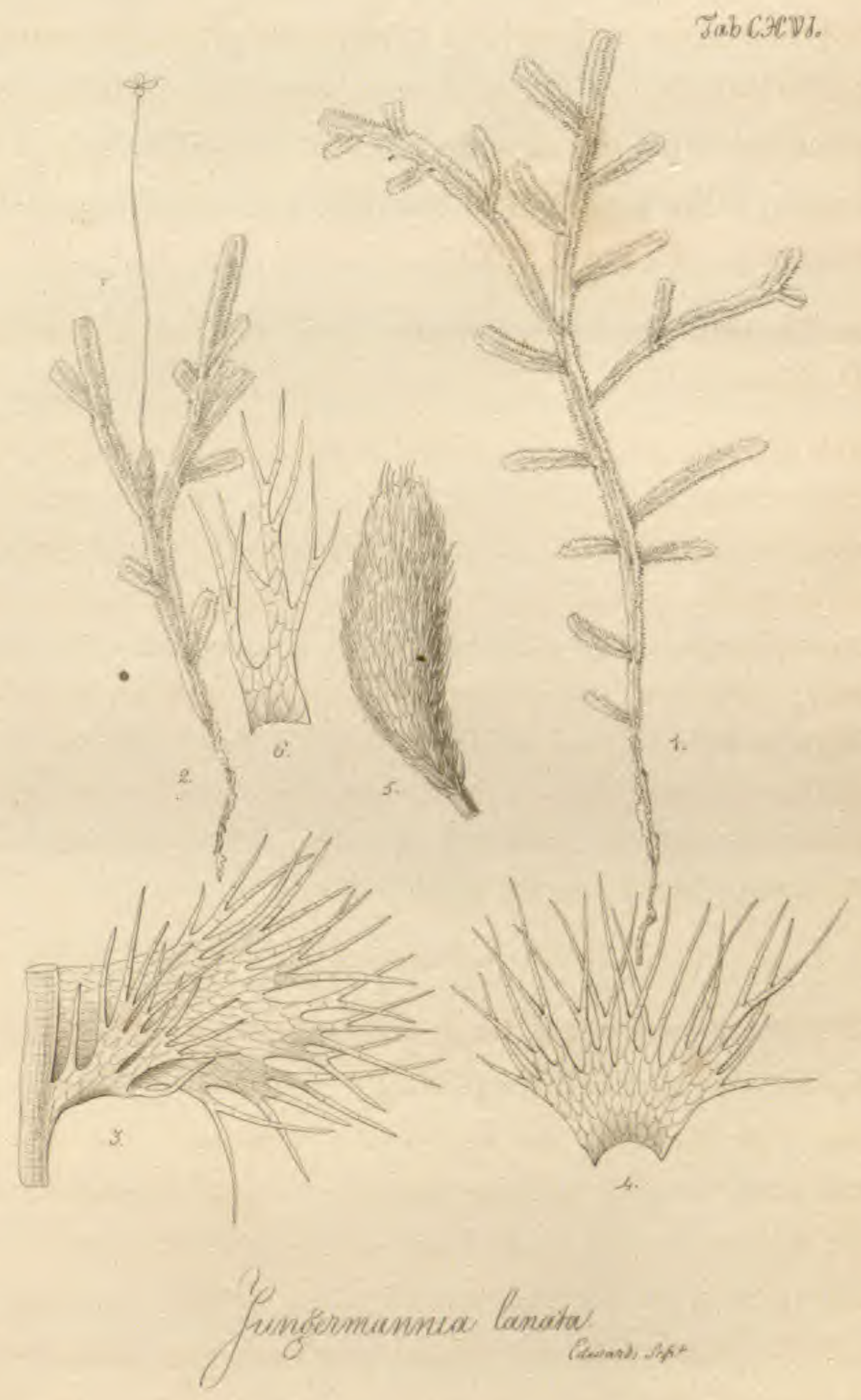


Sab cattin
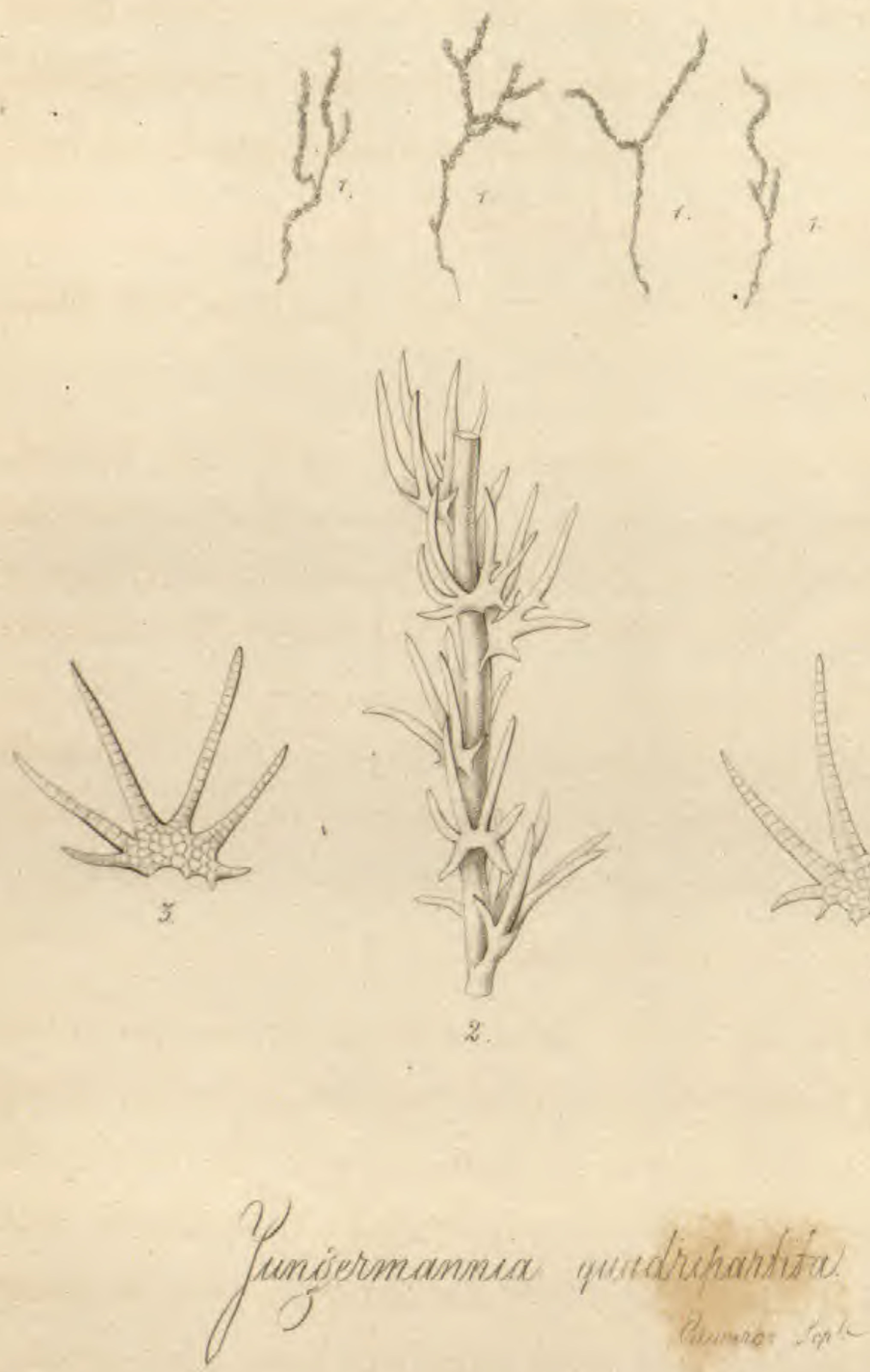


\section{Musci Ex о т с 1.-Menziesiani.}

\section{JUNGERMANNIA QUADRIPARTITA.}

Jungermannia caule erecto subdichotome ramoso flexuoso, foliis undique insertis distantibus erecto-patulis 4-partitis, segmentis capillaribus integerrimis vel basi sublaciniatis. (TАB, CXVII.)

HAB. In insula Staten Land dicta, prope Cape Horn. D. Menzies, 1787.

Caules vix unciam longi, filiformes, erecti, rigidi, nigri, flexuosi, subdichotome ramosi, ramis plerumque simplicibus flexuosis. Folia (apicibus ramorum exceptis ubi flavescentia sunt) intense nigro-viridia, undique inserta, distantia, erecta, vel erecto-patentia, ad basin fere quadripartita, segmentis divaricatis, capillaribus aut paululum attenuatis, integris vel basi solummodo laciniatis, laciniis brevibus horizontalibus recurvisque; sulstantia areolis parvis reticulata, segmentis quasi articulatis.

There are smaller leaves mixed with the larger ones in this plant, which I should be disposed to consider as stipules, if they were placed with any sort of regularity. As a species it is very remarkable, coming nearer than any other to J. setiformis, Brit. Jung. (TАB.XX.) in the quadrifid division of the leaf. Its colour is peculiarly black, except at the apices which are yellow-green.

Fig. 1, 1, 1, 1, plants, nat. size. Fig. 2, portion of a stem and leaves. Fig. 3, 3, leaves,-magn. 
Musci Exotri.--Menziesiani.

\section{JUNGERMANNIA MENZIESII.}

Jungermannia caule elongato repente dense bipinnatim ramoso ; foliis distichis horizontalibus inæqualiter bilobis conduplicatis ciliatis, lobis rotundatis, lobulis minutis oblongis, ramorum claviformi-saccatis, stipulis quadrifidis ciliatis, ramorum segmentis duobus claviformi-saccatis. (TAв. CXVIII.)

HАB. In insula Staten Land dicta, prope Cape Horn. D. Menzies, 1787.

Caulis 3-4-pollicaris, repens, subflexuosus, dense bipinnatim divisus, pinnis pinnulisque horizontalibus. Folia arcte imbricata, horizontalia, disticha, fuscescentia, nitore expertia, inæqualiter biloba, pulcherrime ciliata, ciliis longis subdistantibus, lobis conduplicatis; superiorilus seu majoribus rotundatis planiusculis; inferiorilus seu lobulis multo minoribus, caulium oblongis, acuminatis, marginibus recurvis longe ciliatis (fig. 2.), ramorum plerumque claviformi-saccatis nune setigeris (fig. 3.). Stipula magnæ, quadripartitæ, segmentis longe acuminatis, marginibus recurvis ciliatis, ramorum duobus intermediis non raro claviformi-saccatis. (fig. 5.) Fructificationem non vidi.

This species again belongs to the same curious family with J. clavigera, J. magellanica and palpelrifolia, approaching nearest to the latter in the foliage, but differing from it in the leaves being ciliated with long hair-like processes in the undivided lobule, and considerably also in the ramification, which is here closely beset with pinnæ and pinnulæ, and these so horizontally placed that they might almost be called pectinate. Their places of growth are widely distant.

Fig. 1, plant, nat.size. Fig. 2, cauline leaf. Fig. 3, cauline stipule. Fig. 4, leaf from a branch. Fig. 5, stipule from ditto. Fig. 6, portion of a leaf,-magn. 
cob aXXNIy.
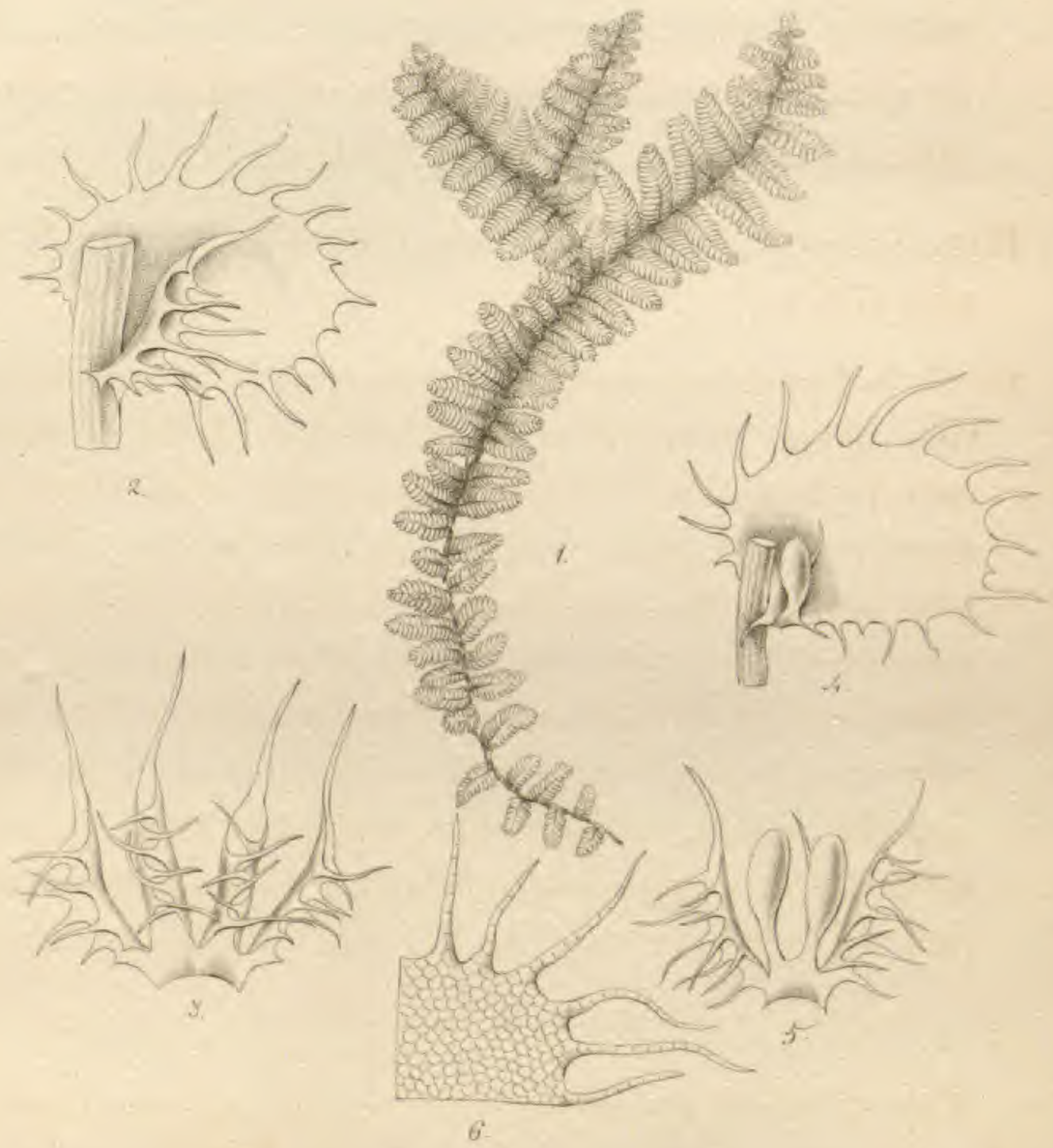

$$
\text { Aungermannear Mencuesia }
$$


Jablexix.
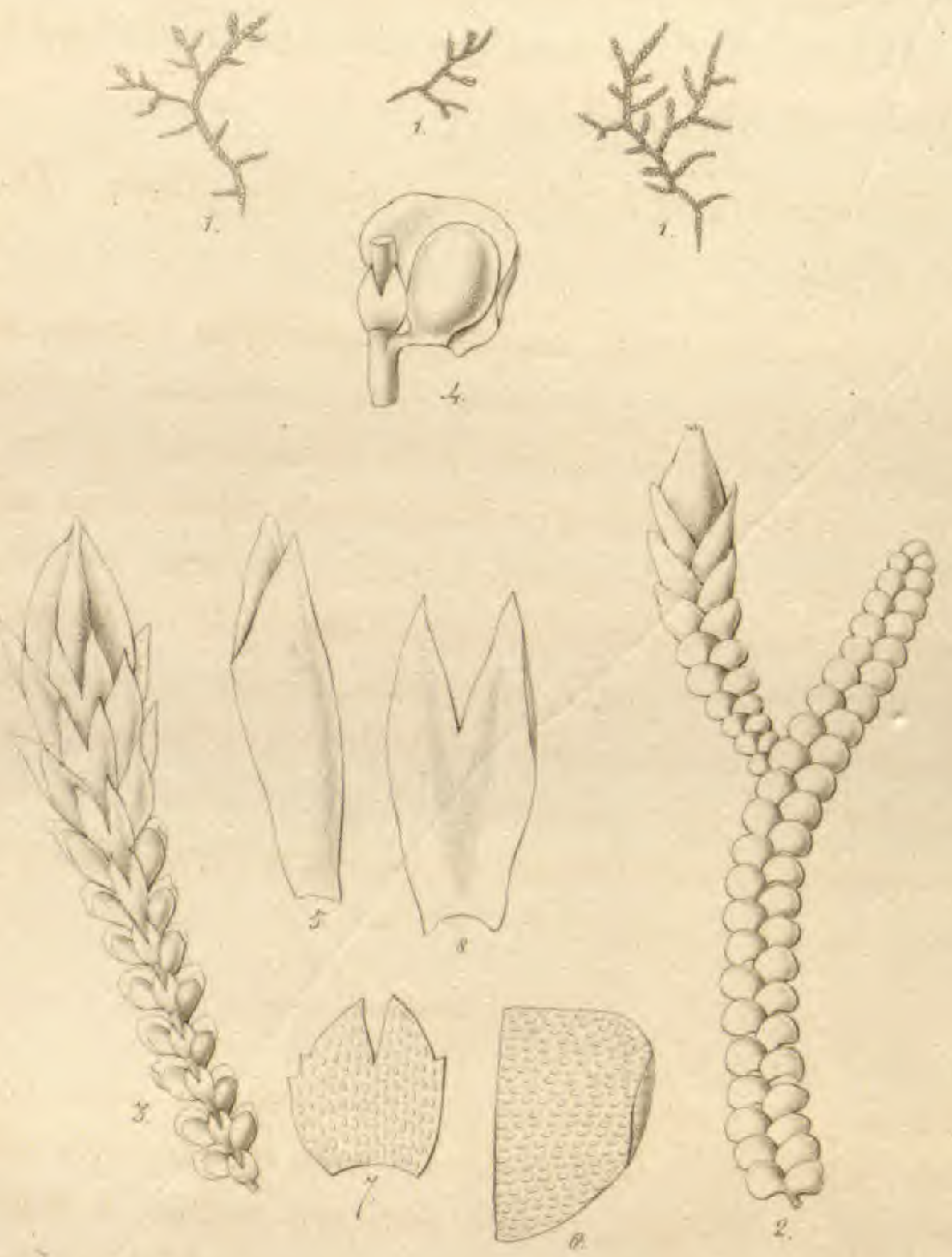

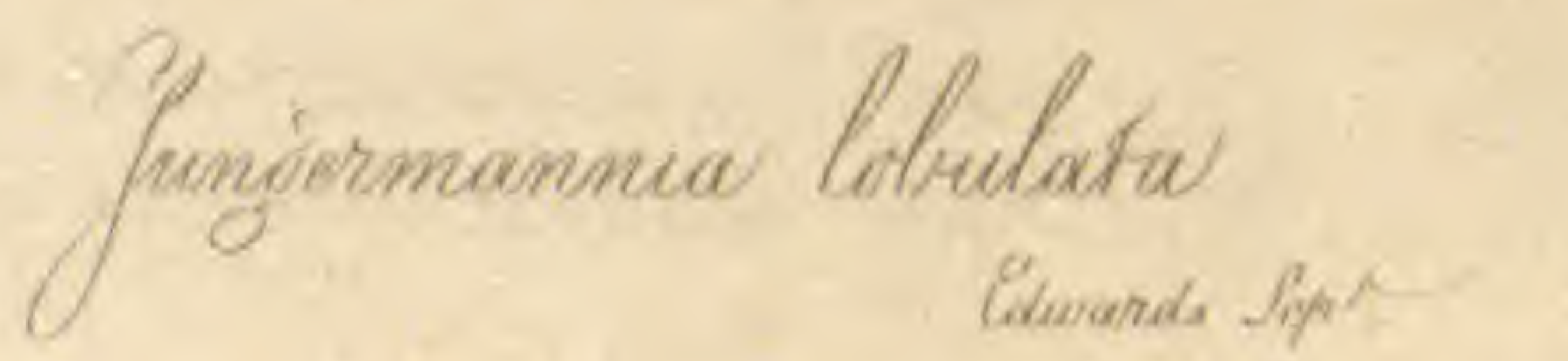


JUNGERMANNIA LOBULATA.

Jungermannia caule repente ramoso, foliis distichis horizontalibus ovato-rotundatis subæqualiter bilobis, lobis conduplicatis inferioribus saccatis, stipulis rotundatis planis emarginatis, calyce oblongo-ovato lævi triangulari. (TAB. CXIX.)

$\mathrm{H}_{\mathrm{AB}}$. In insula Staten Land dicta, prope Cape Horn. D. Menzies, 1787.

Caules vix unciam longi, flexuosi, subpinnatim ramosi, ramulis brevibus. Folia fuscescentia, laxe imbricata, horizontalia, disticha, subæqualiter biloba, lobis conduplicatis ovato-rotundatis, superioribus convexis integerrimis inferioribus saccatis ; sulstantia compacta cellulis minutis punctata. Perichetialia duplo triplove majora, oblonga, lobulis explanatis subæqualiter acutis. Stipula parvæ, rotundatæ, planæ, apice acute emarginatæ, marginibus hic illic denticulo instructis; calycinæ multo majores, oblongæ, subbifidæ. Calyx terminalis, lævis, fuscopurpureus, oblongo-ovatus, dorso plano facie inferiore angulo longitudinali prominente.

There is a peculiar slenderness and neatness about this plant, which at first sight distinguishes it from its very near affinity the European J. dilatata; and in addition to this, I may observe another point of distinction between them, which is, that in this species the smaller lobe is so much larger, as to be almost equal in size to the larger one, and that the calyx is much more attenuated, and perfectly free from tubercles.

Fig. 1, 1, 1, plants, nat. size. Fig. 2, portion of a fructified stem, upper side. Fig. 3, ditto, inferior side. Fig. 4, leaf and stipule. Fig. 5 , stipule. 


\section{Musci Exoтा I.-Menziesiani.}

\section{ORTHOTRICHUM PROREPENS.}

Orthotrichum caule repente, ramis erectis, foliis ovatoattenuatis obtusis dorso carinatis, nervo excurrente, seta longiuscula exserta, capsula exacte ovali łævi, calyptra pilosa. (TAB. CXX.)

HaB. In sinu Dusky bay dicto apud Novam Zeelandiam. D. Menzies, 1791.

Caulis repens, valde ramosus, ramis brevibus, erectis, simplicibus vel iterum divisis. Folia undique imbricata, erecta, (siccitate vix torta,) sordidé fusca, ovata, attenuata, obtusa, dorso insigniter carinato, nervo intense fusco in apiculum breve excurrente instructa. Pericheiialia latiora, oblonga, obtusa, margine parum undulata. Sela e caulis innovationibus' lateralis, 3 ad 4 lineas longa. Capsula rufo-fusca, exacte ovalis. Peristomium simplex (?) e dentibus 16, pallidis, per paria approximatis.

This plant comes nearer to O. apiculatum ( $\mathrm{T}_{\mathrm{AB}}$. XLV.) than any other species of this curious family ; the principal differences consisting in its much smaller proportions; its shorter, denser, and more erect branches; in the different shape of the leaves; and above all, in its very pilose calyptra. The operculum I have never had the opportunity of examining.

Fig. 1, plant, nat. size. Fig. 2, portion of a fructified branch. Fig, 3, leaf. Fig. 4, apex of ditto. Fig. 5, perichætial leaf. Fig. 6, young calyptra,-magn. 
rabexis.

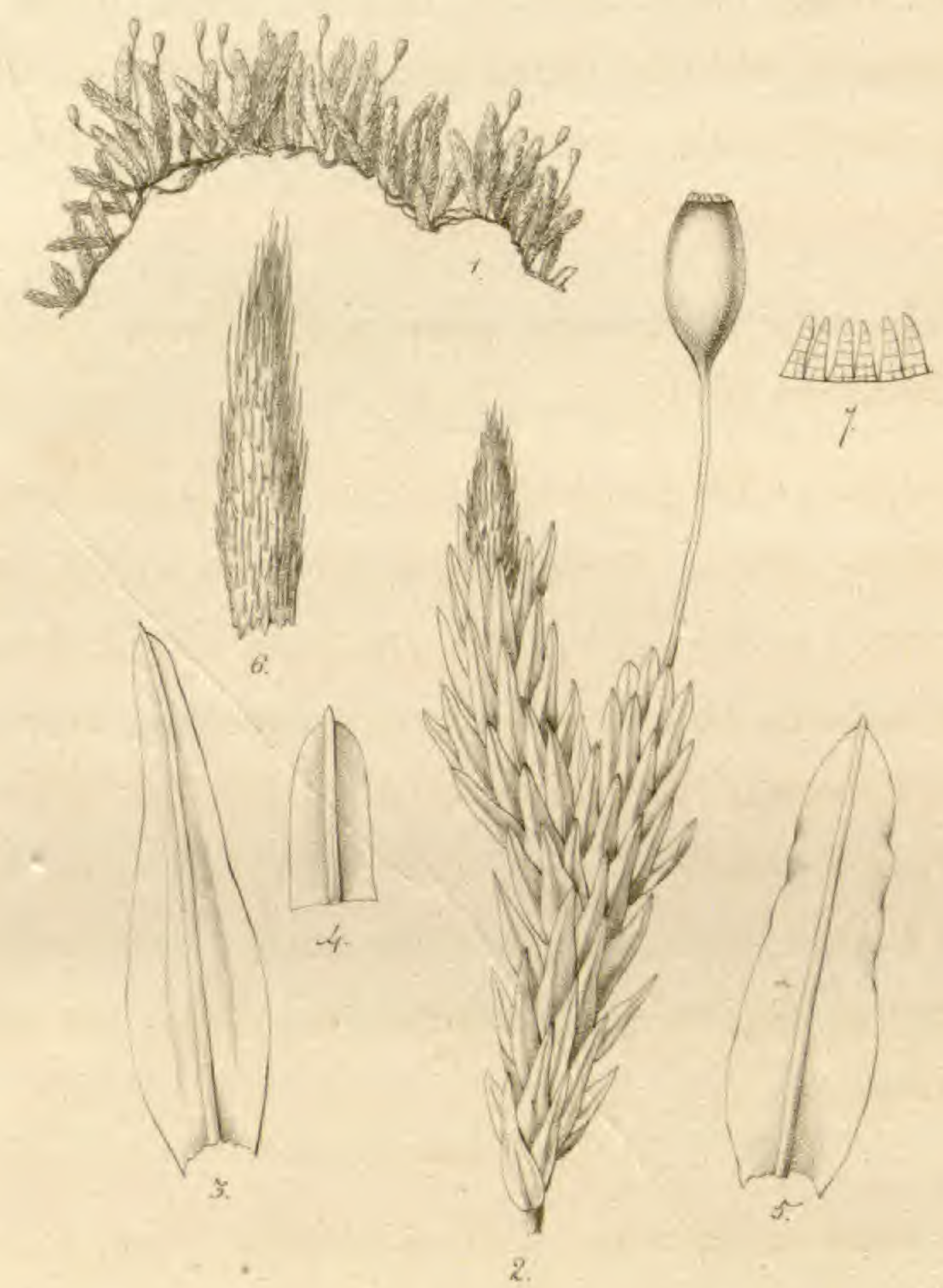

Orithotrichum provepuens.

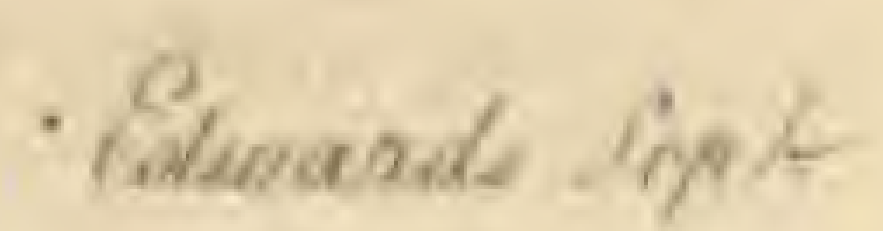




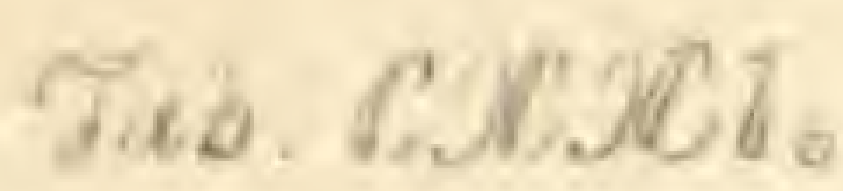

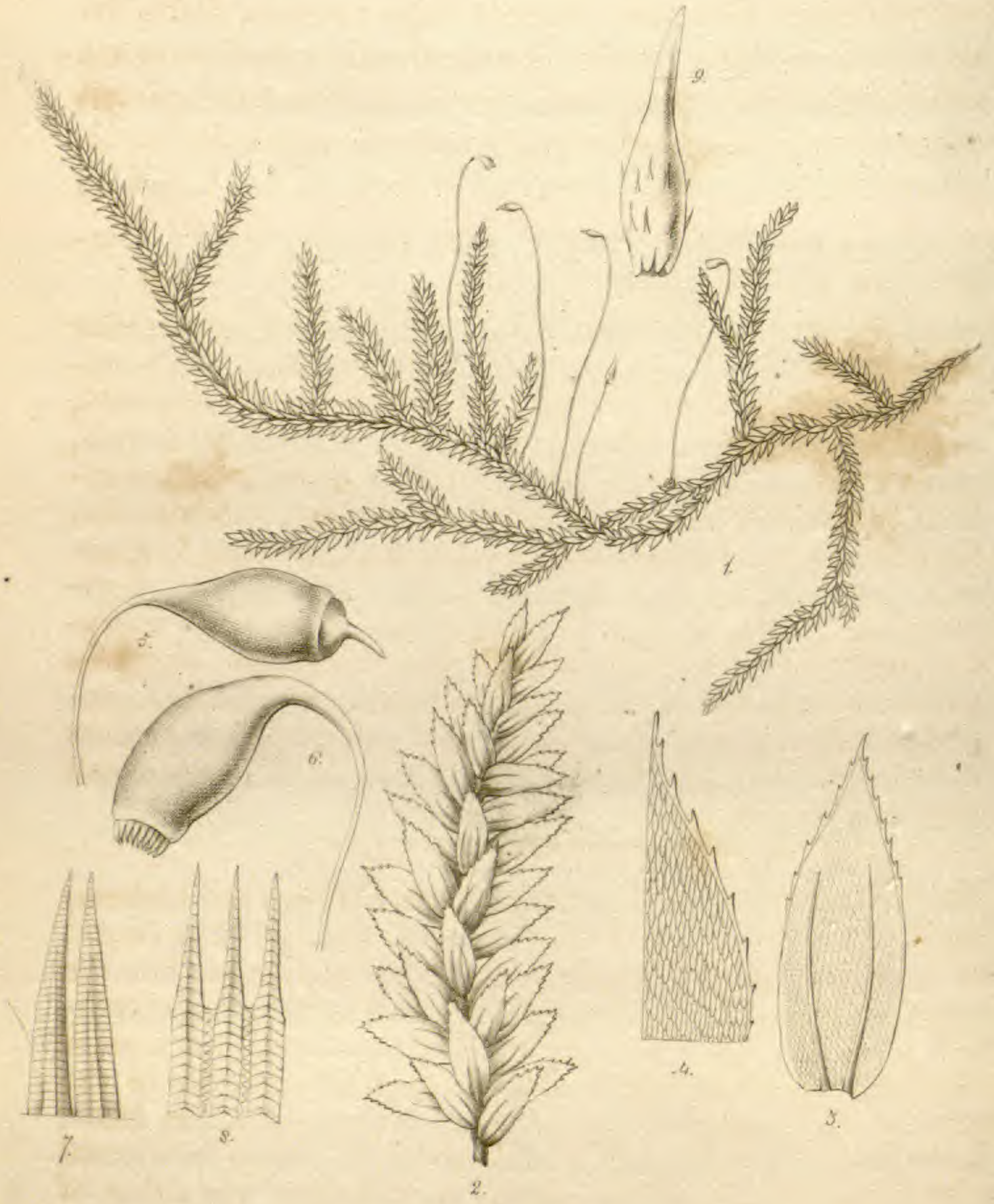

Thmoeria Langisdorffu.

Euwards Poph: 


\section{U S C I Exot I C I._-Swainsoniani.}

\section{HOOKERIA LANGSDORFFII.}

Hookeria caule elongato repente vage ramoso, foliis distichis compressis ovatis subacuminatis membranaceis submarginatis apice serratis, nervis duobus ante apicem evanescentibus, capsula ovata cernua, operculo hemisphærico rostrato, calyptra basi 6 -fida. (TAB. CXXI.)

$\mathrm{H}_{\mathrm{AB}}$. Prope Rio Janeiro Braziliæ legit $\mathrm{Cl}$. Langsdorff; communicavit D. Swainson.

Caules $4-5$-pollicares, rufescentes, repentes, vage sed subpinnatim ramosi, ramis nunc erectis, plerumque simplicibus. Folia undique inserta, sed disticha directione, sordide viridia, subnitida, ovata, subacuminata, submarginata, superne evidenter serrata, nervis duobus e basi usque distinctis, ultra medium evanescentibus, instructa ; sulstantia submembranacea, subpellucida, vix reticulata, cellulis vel areolis valde minutis. Seta longiuscula, gracilis, flexuosa. Capsula ovata, basi elongata, horizontaliter cernua, demum pendula, fusca. Operculum rostratum, basi hemisphæricum, rostro longiusculo curvato. Calyptra mitræformis, pallide fusca, lævis, basi breviter 6-vel S-fida; superficies hic illic corpora pistilliformia gerens. Peristomium Leskea, dentibus ext. intense fuscis, linea media longitudinali diaphana notatis.

For this, as well as some other interesting Mosses and Lichens, I am indebted to my friend W. Swainson, Esq. of Elm-Grove, near Liverpool, who, in a journey which he lately made into the interior of the Brazils, kindly exerted himself in procuring cryptogamic plants for me. The subject here represented has a great resemblance to Hookeria (Leskea, Hedw.) allicans, but in the texture of the leaves is totally different. It also approaches Hook. (Lesk. Hedw.) depressa, but that again has the leaves imbricated on all sides. Our plant is also very much larger than either of those, ard may be reckoned among the handsomest individuals of the genus. Hookeria late-virens may be distinguished from it by the size, and more essentially by the reticulation of the leaves, their want of a thickened margin, and their nearly entire apices; and also in the form and texture of the calyptra.

Fig. 1, plant, nat. size. Fig. 2, portion of a branch with its leaves. Fig. 3, leaf. Fig. 4, portion of ditto to show the reticulation. Fig. 5, capsule and operculum. Fig. 6, capsule without the operculum. Fig. 7, portion of the outer peristome. Fig. 8, portion of inner ditto. Fig, 9, calyptra.-magn.

VoL. II. 
Muscr Exotri.-Menziesiani.

\section{NECKERA AFFINIS.}

Necker a caule ramoso, ramis pinnatis, foliis undique imbricatis erectis lanceolato-acuminatis longe binervibus, seta perbrevi, capsula erecta cylindracea. (ТАB. CXXII.)

Neckera composita, var. ß. Schwaegr. Sp. Musc. v. 2. p. 156 ?

Hab. Ex insula Sancti Vincentii, a D. Menzies communicata.

Caules 3-4-unciales, vage ramosi. Rami erecti, eleganter pinnatim divisi, pinnis erecto-patentibus, breviusculis, simplicibus, attenuatis. Folia fusco-viridia, undique imbricata, erecta vel erecto-patentia, lanceolato-acuminata, parum concava vel carinata, margine plana, inferne præcipue, omnino integerrima, apice sæe torta, binervia, nervis validis, fuscis, folio parum brevioribus atque dorso apicibus eminentibus. Perichatialia lanceolato-subulata, squarrosa, basi solummodo binervia. Seta perbrevis, erecta vel curvula. Capsula cylindracea, erecta, intense fusca. Peristomii dent. ext. pallide rufescentes : cilia setacea, pallida.

This I received from Mr. Menzies marked as the Neckera composita of Hedwig, and I believe it to be the var. $\beta$. of that plant of Schwaegrichen. To me, however, it appears to differ specifically, not only in its larger size and less compound ramification, but also more strikingly in its leaves, which are much larger and narrower.

Fig. 1, plant, nat. size. Fig. 2, portion of the stem with fructification. Fig. 3,3, leaves. Fig. 4, perichætium and capsule. Fig. 5, leaf of the perichætium. Fig. 6, portion of the peristome,-magn. 
sab $C X X y$.

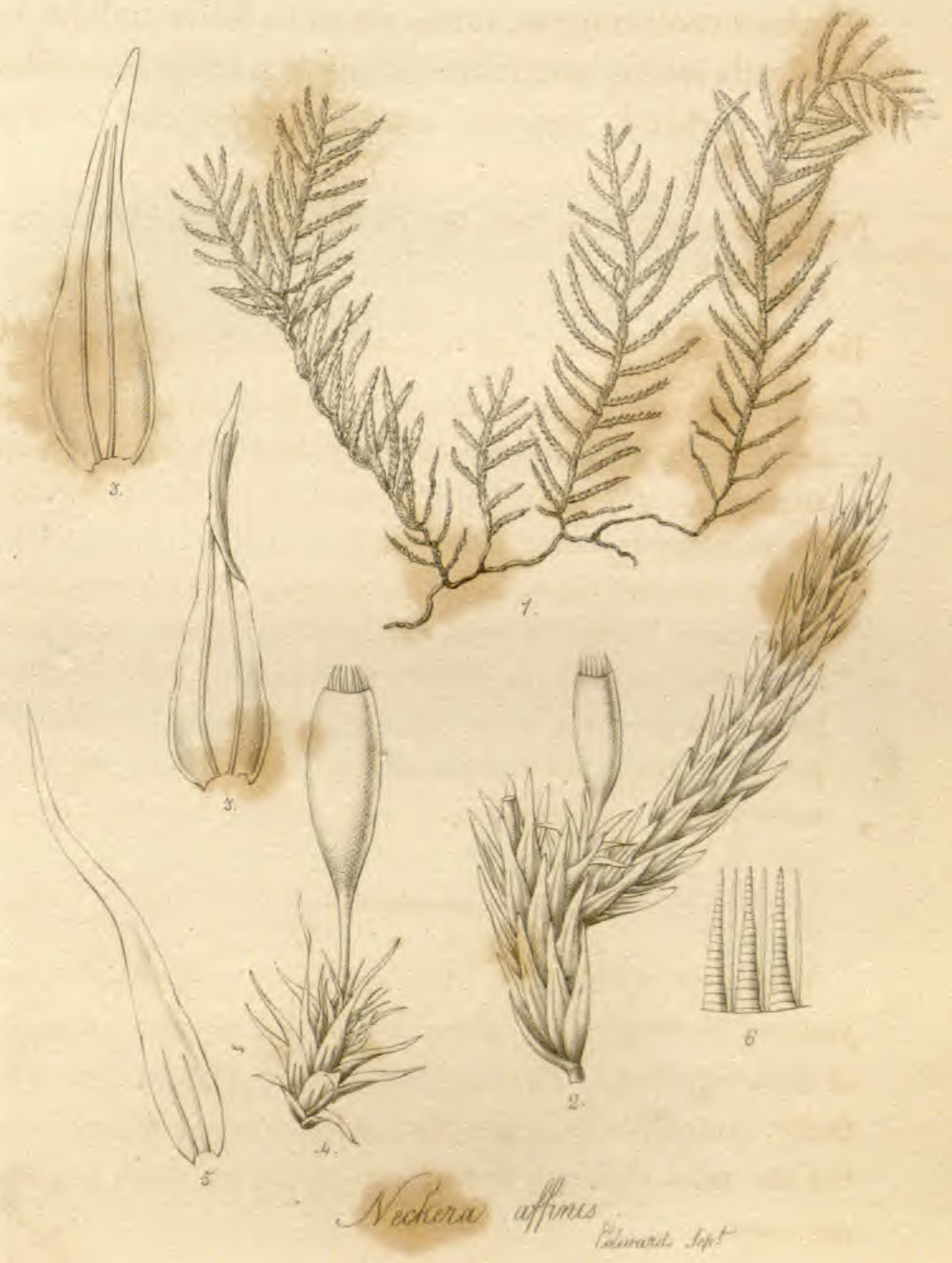


Tod QXONJ8.

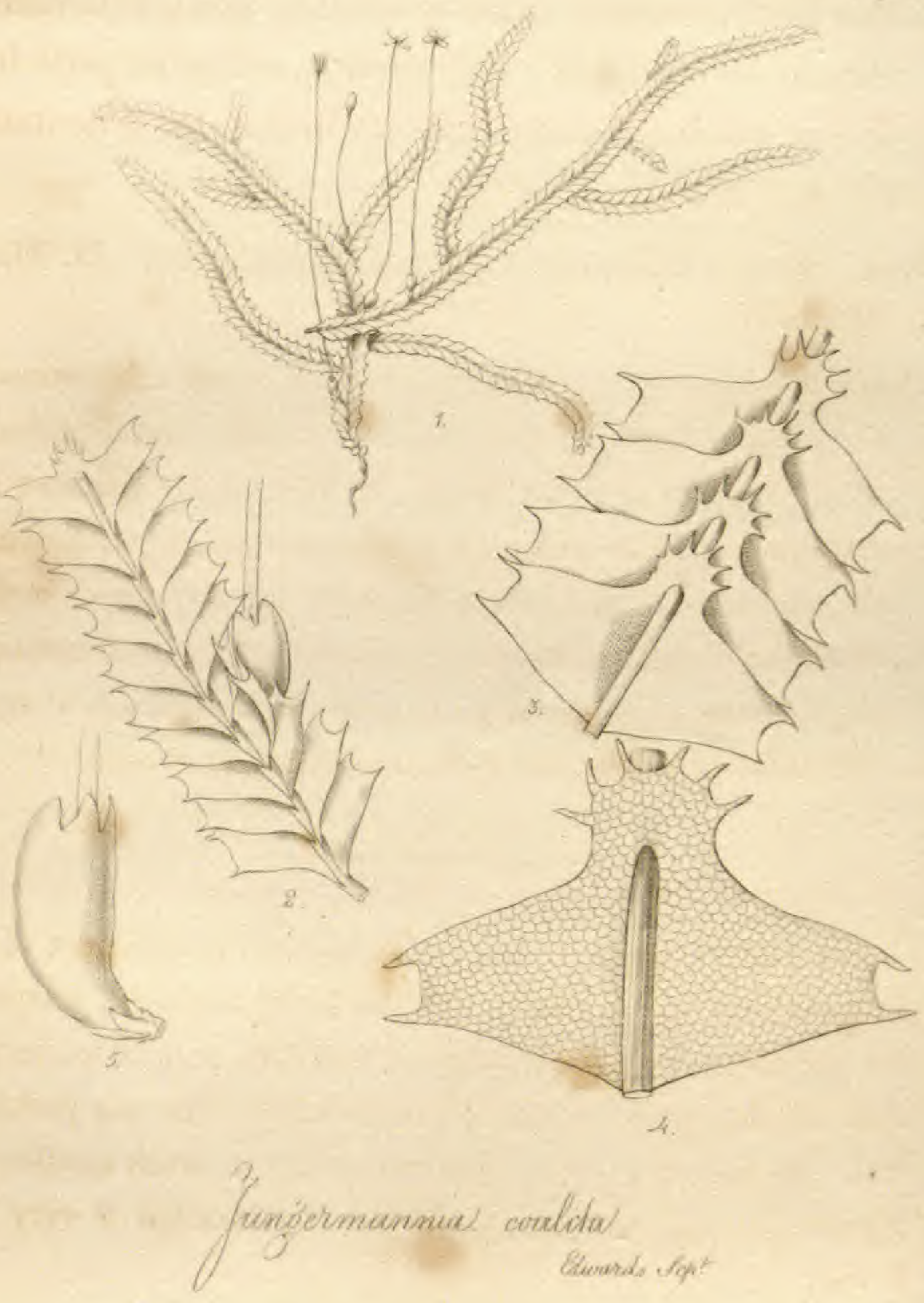




\section{Musci Exoтrс.-Menziesiani.}

\section{JUNGERMANNIA COALITA.}

Jungermannia caule repente vage ramoso, foliis distichis horizontalibus ovato-quadratis, apice bidentatis, stipulis iis coadunatis 5-6-dentatis, calyce ex parte inferiore caulis, obovata basi attenuata, ore 4-dentato. (Tав. CXXIII.)

Hab. In sinu Dusky bay dicto in Nova Zeelandia. D. Menzies, 1791 .

Caules 3-pollicares, repentes, vage ramosi, ramis subattenuatis. Folia fusca, opposita, disticha, horizontalia, ovato-quadrata, apice bidentata, dentibus longis acutis, margine inferiore decurrente, superiore cum stipulis subquadratis, 5 - vel 6-dentatis coadunato. Substantia foliorum stipularumque mollis, areolis rotundatis grandiusculis reticulata. Calyx subcarnosus, nigro-fuscus, ex inferiore parte caulis, basi attenuata et squamis parvis instructa, ore 4-dentato, dentibus obtusis.

This remarkable plant has certainly much resemblance to the $J$. connata of Swartz, which like this has the superior margin of the leaf united with the stipules, so that each pair of leaves with their stipules appear, especially from behind, like one perfoliate leaf. In Swartz's plant, however, which is much smaller, the stipules are only bidentate, and the fructification is very different.

Fig. 1, plants, nat. size. Fig. 2, portion of a fructified stem, superior side. Fig. 3, inferior side of a portion of the stem and leaves. Fig. 4, leaves and stipules. Fig. 5, calyx.-magn. 


\section{ORTHOTRICHUM URCEOLATUM.}

Orthotrichum caule repente, ramis erectis, foliis lanceolato-attenuatis dorso carinatis, nervo attingente, seta sublonge exserta, capsula urceolata lævi, calyptra nuda sulcata longe multifida.

(TAB. CXXIV.)

HAB. In Insula Sanctæ Helenæ. D. Menzies, 1795.

Caules repentes, valde ramosi, ramis numerosis, crassis, brevibus, apicibus sæpe divisis. Folia nigro-viridia, superiora fusco-viridia, omnia arcte denseque imbricata, curvato-patentia, siccitate vix torta, lanceolato-attenuata, acuta, dorso parum carinata, nervo valido ad apicem attingente instructa. Perichatialia his breviora, acuta, substriata. Seta e caulis innovationibus sæpe lateralis, semiunciam longa. Capsula urceolata, rufo-fusca, lævis, ore contracto. Opexculum subulatum, rectum. Calypira campanulata, nuda, fusco-lutea, sulcata, basi ad dimidiam partem longitudinis in segmenta 8-10 angusta fissa. Peristomium, ut videtur, simplex, e dentibus pallidis, brevibus, integris, linea longitudinali media notatis, non raro apice fissis.

At first sight it might be difficult to distinguish this plant from Orthotrichum prorepiens ( $\mathrm{T}_{\mathrm{AB}} . \mathrm{CXX}$.), were it not for its stouter branches and urceolate capsules. The leaves of the two species are also much alike, but shorter and more acute in all that I could find entire upon the present subject; for it is remarkable, that though the specimens in my possession are in other respects very good, it was difficult to discover a single leaf of which the point was not broken. The essential differences must be looked for in the calyptra, which is here naked, sulcate, and deeply cleft from the base upwards into a number of linear segments.

Fig. 1, 1, plants, nat. size. Fig. 2, portion of a stem with fructification. Fig. 3, leaf. Fig. 4, perichætial leaf. Fig. 5, capsule. Fig. 6, operculum. Fig. 7, calyptra. Fig. 8, portion of the peristome,-magn. 
Fab cxorv.

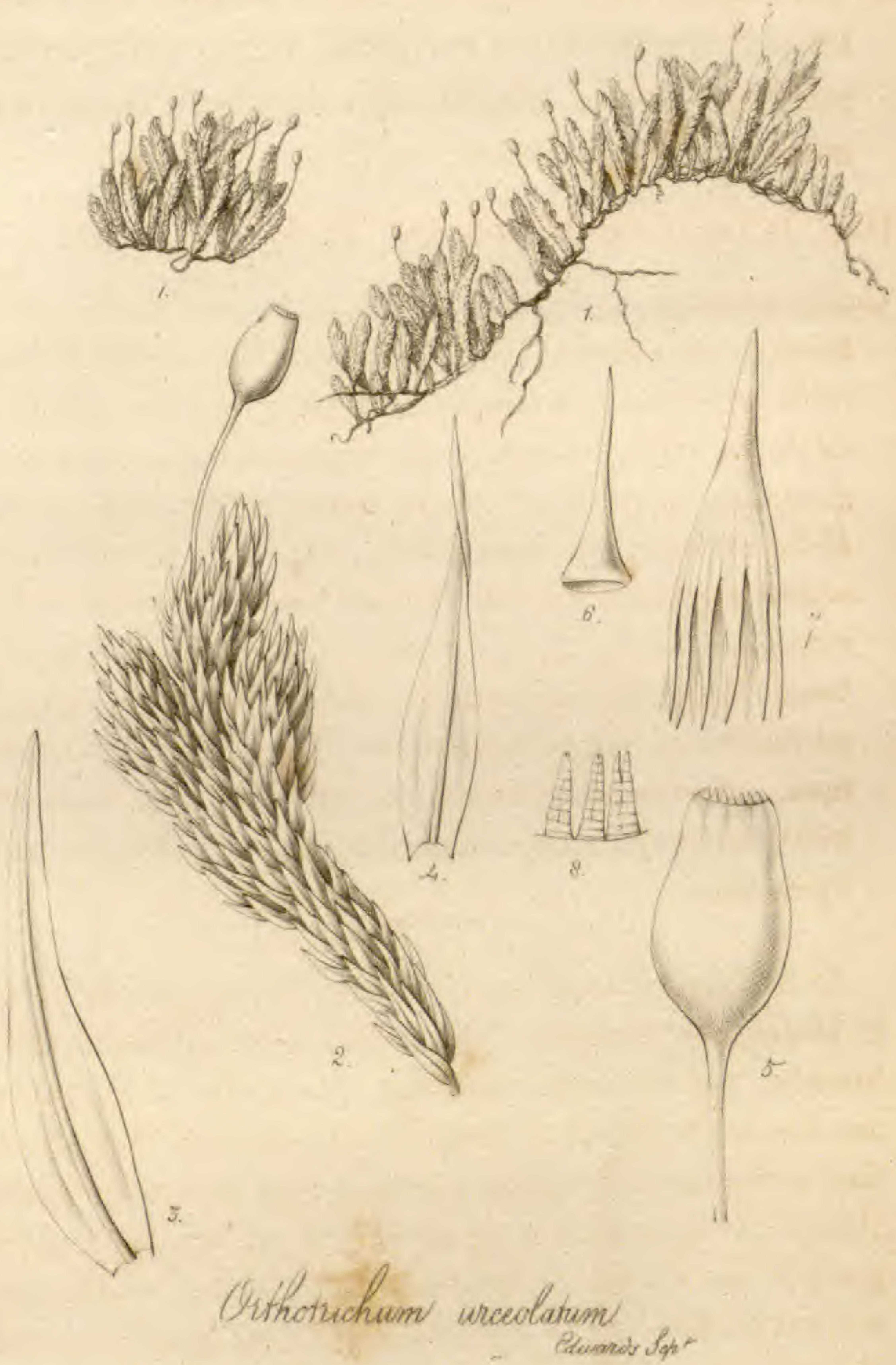


Jab. UXX:

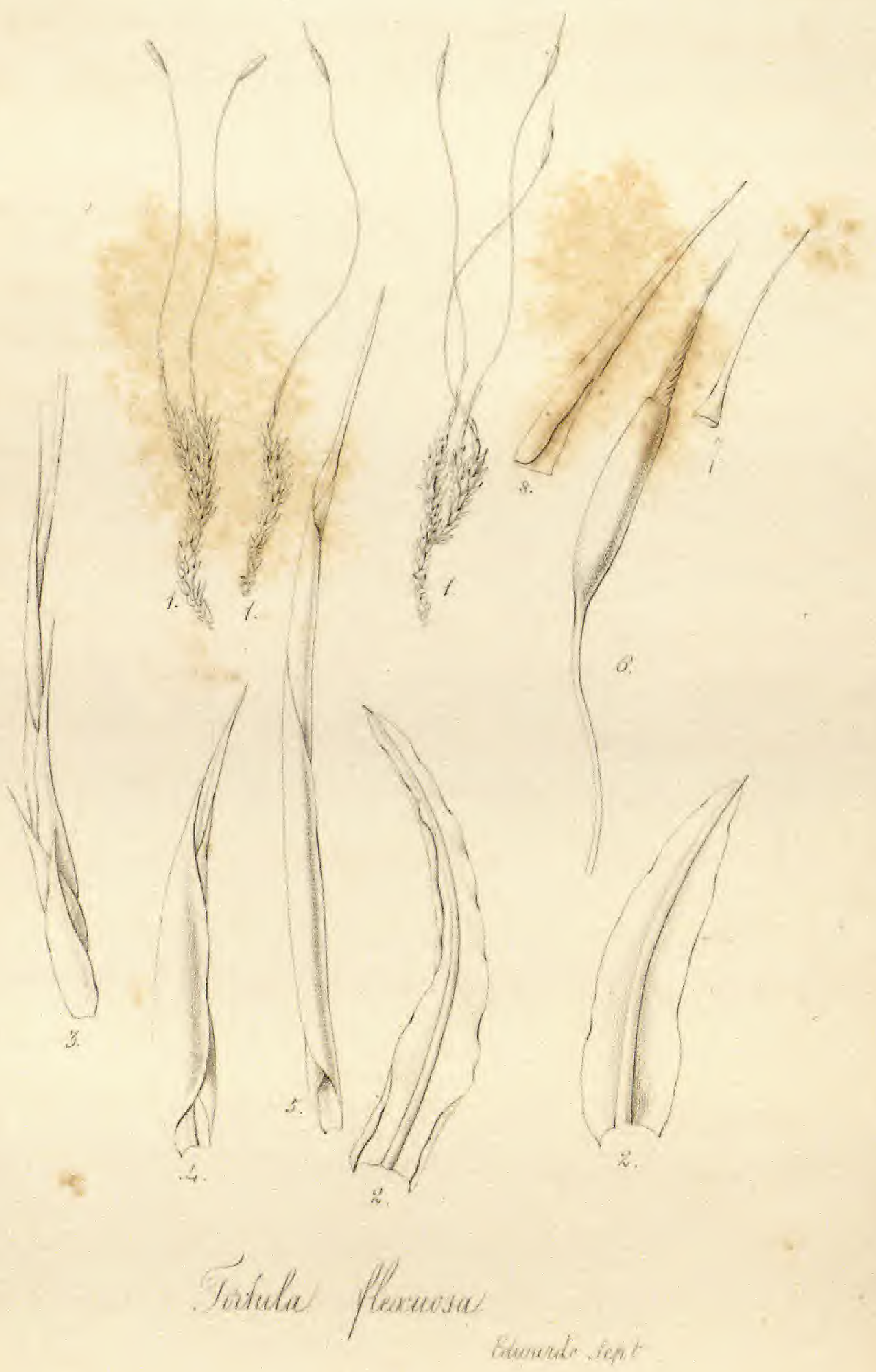




\section{TORTULA FLEXUOSA.}

Tortula caule elongato ramoso, foliis lanceolato-linearibus carinatis nervo excurrente, perichætialibus longissimis vaginantibus, capsula cylindracea, operculo longe subulato.

(TAB. CXXV.)

НАв. Ad promontorium Bonæ Spei. D. Menzies, 1791.

Caules vix unciam longi, erecti, crassiusculi, apicem versus præcipue ramosi. Folia fusco-viridia, arcte imbricata, erectopatentia, rigidiuscula, lineari-lanceolata, carinata, margine subundulata, nervo valido, intense fusco, paulo ultra apicem excurrente instructa. Perichcetialia elongata, setæ basin insigniter vaginantia atque circumvoluta, flavo-fusca, attenuata, nervo obscuro. Seta biuncialis, flexuosa, flavo-rufescens. Capsula cylindracea, intense fusca. Calyptra subulata, basi hinc fissa. Operculum subulatum, capsula subæque longum. Peristomium longum, flavo-rufescens, e dentibus vel ciliis spiraliter tortis.

This plant in the curious structure of the perichætium will rank with Tortula convoluta, revoluta, and T. pilifera of this work ( $\mathrm{T}_{\mathrm{AB}}$ XII.), differing from all in its flexuose fruitstalks, and their great length. The operculum and the peristomium too are remarkably long, as well as the perichætial leaves.

Fig. 1, 1, 1, plants, nat. size. Fig. 2, 2, leaves. Fig. 3, perichætium. Fig. 4 and 5, leaves of ditto. Fig.6, capsule and peristome. Fig. 7, operculum. Fig. 8, calyptra.-magn. 


\section{Musci Exoт г 1.-Menziesiani.}

\section{LEUCODON LAGURUS.}

Leucodon caule erecto tomentoso ramoso, foliis imbricatis ovatis concavis acuminulatis enervibus, capsula erecta cylindracea, operculo acuminato. CXXVI.)

(TAB.

Hypnum lagurum. Menzies MSS.

HAB. In insula Staten Land dicta, prope Cape Horn. D.Menzies, 1787.

Caules cæspitosi, inferne tomento ferrugineo obsiti, ramosi, ramis erectis, cylindraceis. Folia undique imbricata, erecta, flavescentia, nitida, ovata, valde concava, integerrima, enervia, apice in acumen breve piliforme desinentia. Perichatialia circa caulis basin convoluta, lanceolata, apice subrecurva. Seta lateralis, 4 ad 6 lineas longa. Capsula erecta, cylindracea, flavo-fusca. Operculum acuminatum, subobliquum. $\mathrm{Ca}$ lyptra dimidiata, flavescens. Peristomium simplex, dentibus, e membrana paulo ultra capsulæ marginem exserta, 16, filiformibus, pallide flavescentibus, longitudinaliter striatis, ad basin usque fissis, segmentis erectis.

Widely differing in shape as the leaves of this species do from those of Leucodon tomentosus, there yet is a close affinity between the two plants, and it is the more satisfactory to find how nearly their peristomes agree together. The present plant is very beautiful, of a bright shining yellow colour in the leaves, while the lower parts of the stem are covered with a ferruginous down.

Fig. 1, 1, 1, plants, nat. size. Fig. 2, single plant. Fig. 3, 3, leaves. Fig. 4, 4, perichætial leaves. Fig. 5, capsule. Fig. 6, operculum. Fig. 7, calyptra,-magn. 
Tub axabs

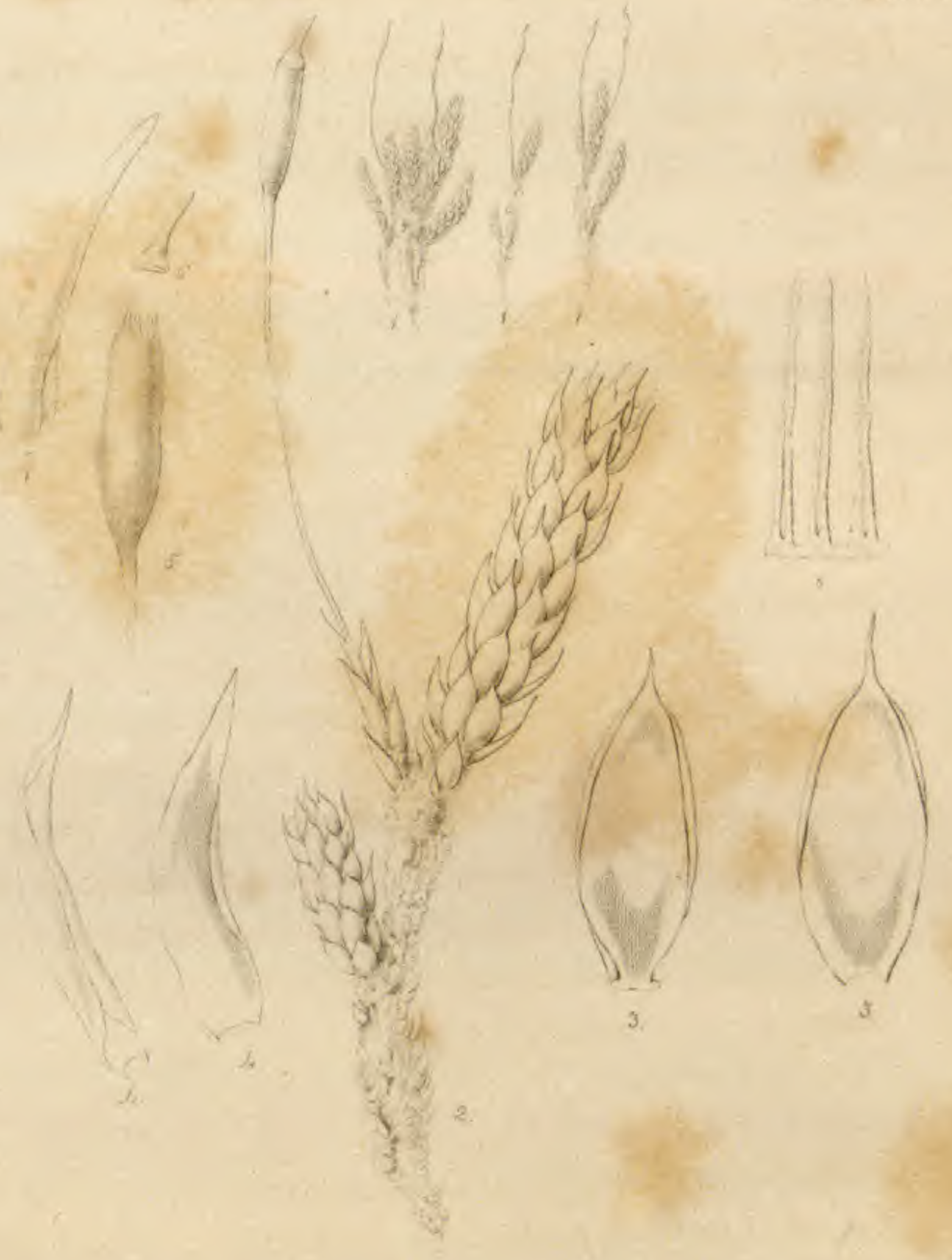

Leusontum lavores.

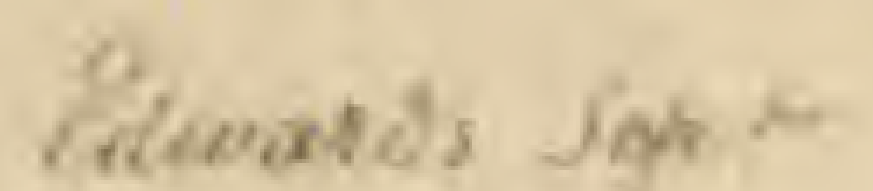


Jab. cxxyd.

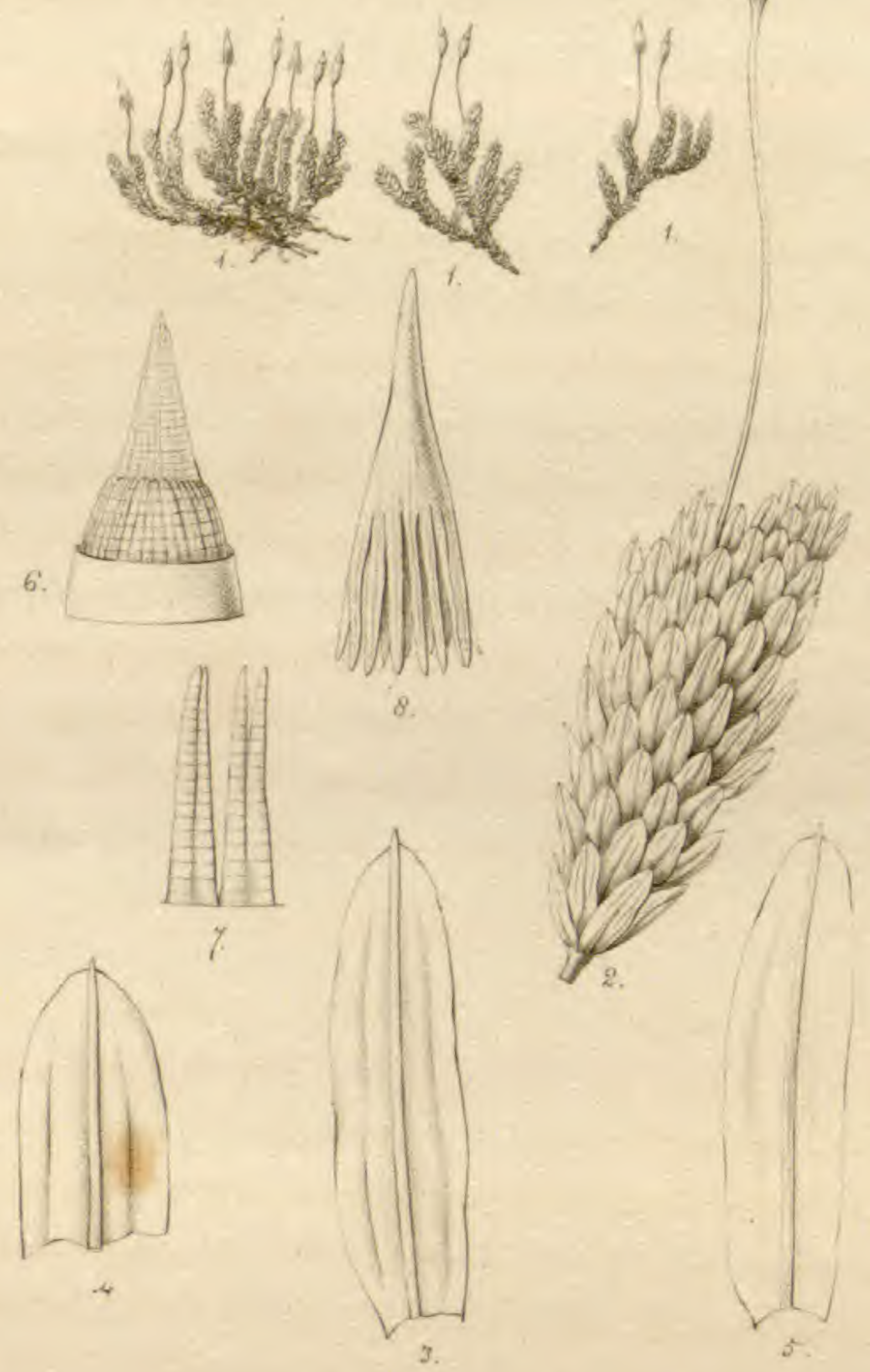

Brthotrishum Swainsomi:

Qdewarks Sht 


\section{Musci Exot r c1.-Swainsoniani.}

\section{ORTHOTRICHUM SWAINSONI.}

Orthotrichum caule repente, ramis erectis, foliis ellipticis longitudinaliter plicatis, nervo breviter excurrente, seta longiuscula, capsula ovata lævi, calyptra nuda sulcata longe multifida. (Tав. CXXVII.)

Hab. Prope Rio Janeiro Americæ meridionalis. D. Swainson.

Caules repentes, ramosi, ramis erectis iterum divisis. Folia nigro-fusca, superiora viridia, dense imbricata, erecto-patentia, siccitate torta, elliptica, plicis duabus longitudinalibus, nervo pallido ultra apicem in apiculo producto. Perichatialia minus plicata, magis membranacea. Seta semiunciam longa, flexuosa. Capsula ovata, lævis. Calyptra campanulata, nuda, fusco-lutea, sulcata, basi ad dimidiam partem longitudinis in segmenta numerosa angusta fissa. Operculum basi hemisphæricum, apice acuminatum. Columella cellulosa longe exserta. Peristomium simplex, e dentibus longiusculis, albidis, erectis, 16 , linea media longitudinali notatis, ad apicem sæpe fissis.

This and the subject of the following plate were gathered last year in the province of Bahia, in the Brazils, by W. Swainson, Esq. They are remarkable for the structure of the columella, which is so much exserted beyond the peristome as to present very much the same appearance as the capsule of Sclotheimia squarrosa, figured by Schwaegrichen; nor can I well persuade myself that what is considered by that author as a peristome, can in reality be such, or anything more than a continuation of the columella, which in a more advanced state may appear cleft.

Fig. 1, plants, nat. size. Fig. 2, portion of a stem and fructification. Fig. 3, leaf. Fig. 4, apex of ditto. Fig. 5, perichætial leaf. Fig.6, peristome and exserted columella. Fig. 7, teeth of the peristome. Fig. 8, calyptra,-magn. 


\section{Musci Exotr c I.-Swainsoniani.}

\section{ORTHOTRICHUM RUGIFOLIUM.}

Orthotrichum caule repente, ramis erectis, foliis ellipticis substriatis rugosis nervo breviter excurrente, seta longiuscula, capsula ovato-oblonga lævi, calyptra campanulata nuda glabra basi 4-dentata. (TAB. CXXVIII.)

$\mathrm{H}_{\mathrm{AB}}$. Prope Rio Janeiro Americæ meridionalis. D. Swainson.

Caules repentes, valde ramosi, ramis erectis. Folia dense imbricata, erecto-patentia, fuscescentia, superiora viridia, elliptica, substriata, apice insigniter plicato-rugosa, nervo validiusculo paulo ultra apicem excurrente instructa. Perichatialia minus rugosa, sed acuta. Seta semiunciam longa. Capsula ovato-oblonga. Calyptra campanulata, nuda, glabra, castanea, basi in dentibus 4 , brevibus, membranaceis fissa. Operculum e basi hemisphærica acuminatum. Columella atque Peristomium omnino ut in O. Swainsoni (TAB. CXXVII.)

Here again is an Orthotrichum, which at first sight is scarcely distinguishable from $O$. Swainsoni; yet, besides the remarkable rugosity of the leaves, the calyptra is of a totally different structure, very much resembling that of Encalypta ciliata. In this respect also it precisely accords with Sclotheimia squarrosa, but differs from it in its much smaller size, in the rugosity of the leaves towards their apex, and in the peristome, if that figured by Schwaegrichen be correct.

Fig. 1, 1, 1, plants, nat. size. Fig. 2, portion of a stem and fructification. Fig. 3, leaf. Fig. 4, apex of ditto. Fig. 5, perichætial leaf. Fig. 6, capsule. Fig. 7, peristome and columella. Fig. 8, calyptra. Fig. 9, teeth of peristome.-magn. 


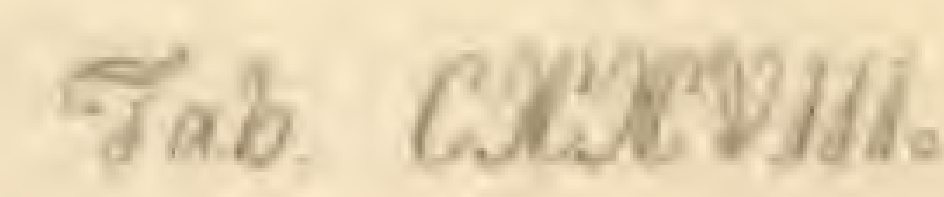

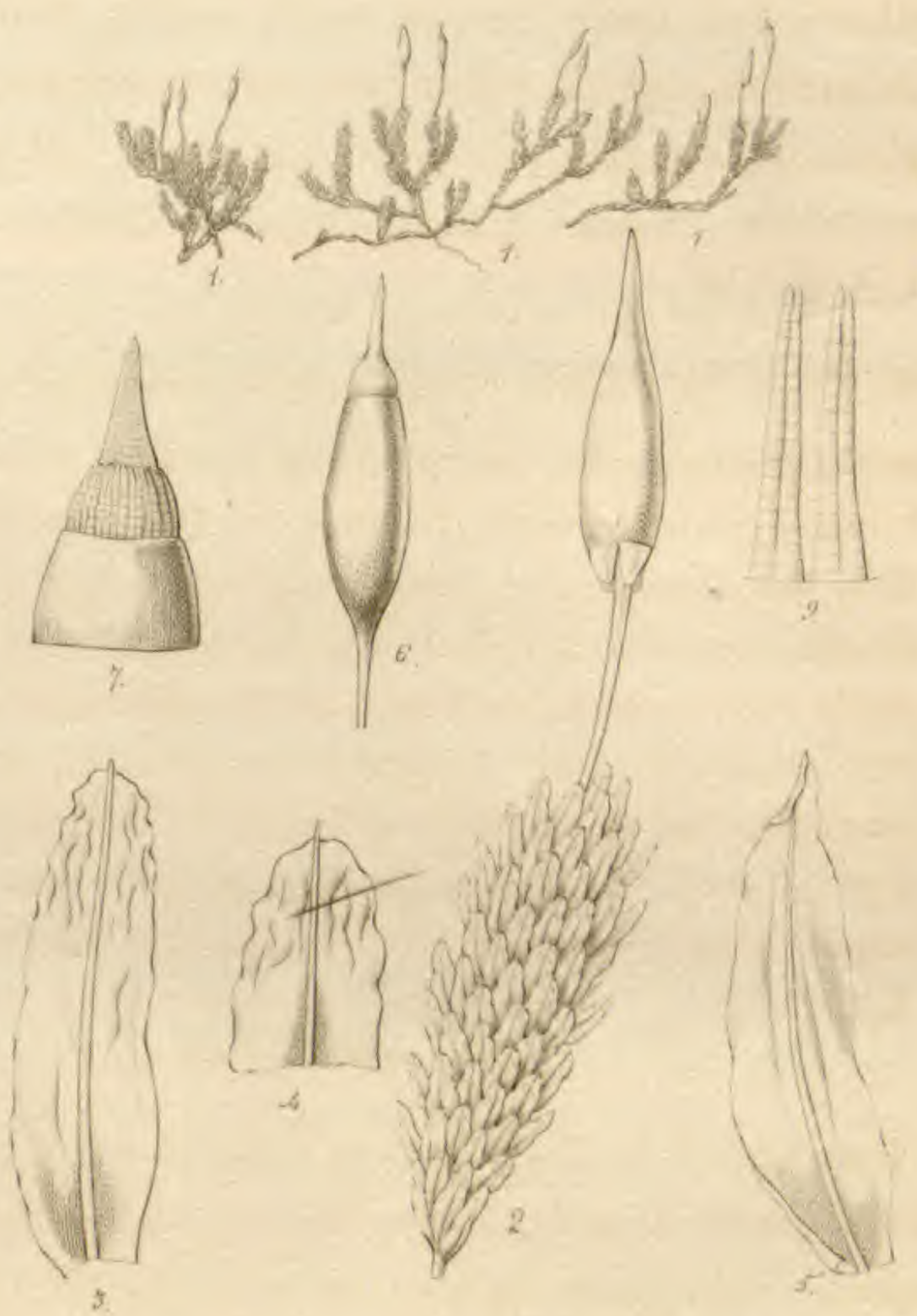

Orthotuchum zusiftuen.

Elwazds Sopt 
Jab axxyx

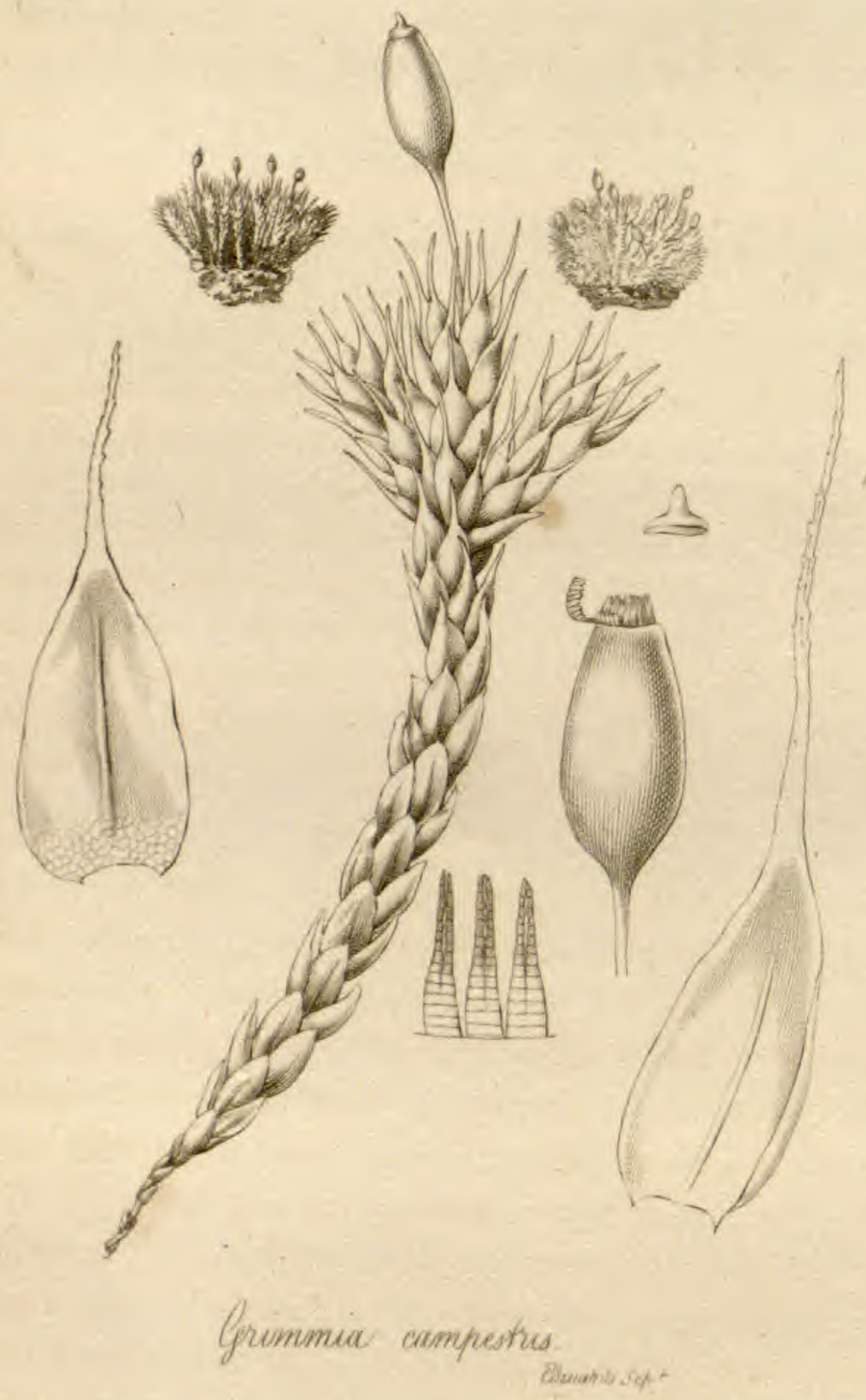




\section{GRIMMIA CAMPESTRIS.}

Grimmia caule erecto cæspitoso ramoso, foliis undique erecto-patentibus late ovatis longe acuminatis incanis, seta exserta recta, capsula ovata, operculo brevi-rostrato. (ТАв. CXXIX.)

Grimmia campestris. Burchell MSS.

$\mathrm{H}_{\mathrm{AB}}$. In territorio coloniali Capitis Bonæ Spei, in regione Roggeveld, inter Jakhals Fonteyn et Kuylenberg;-terrestris, in campis aridis, parce. D. Burchell.

Caules ut in Grimmia pulvinata, dense cæspitosii, erecti, versus apicem ramosi. Folia undique sublaxe imbricata, erecto-patentia, nigro-viridia, late ovata, concava, inferiora obtusa, superiora in pilum, folii longitudine æquale, vel in 'summitate duplo longius, incanum, serrulatum attenuata, nervo obscuro ante pili basin evanescente. Seta brevis, erecta. Capsula ovata, pallide fusca, ore annulato. Operculum brevi-rostratum, obtusum. Peristominm e dentibus 16, longiusculis, intense rufis, transversim striatis, superne sæpissime fissis.

Numerous are the species (if such they may be really called) of Grimmia, bordering upon G. ovata and pulvinaia, differing from each other in the various modifications of the leaves, the fruitstalk, the capsule and operculum. The subject of the present plate is one which, in the fructification, much resembles the former of the species just mentioned, while it is totally different from it in the leaves, therein perhaps coming nearer to G. crinita. The teeth are pretty regularly cleft for nearly half the way down from the apex; so that those botanists who do not corsult nature in the formation of genera, nor take the calyptra into account as essential for their construction, will make this plant a Dicranum.

Fig. 1, 1, tufts of plants, nat. size. Fig. 2, single plant. Fig. 3, leaf. Fig. 4, superior ditto. Fig. 5, capsule with its peristome and annulus. Fig. 6, portion of the peristome. Fig. 7, operculum.-magn.

VoL. II. 
TORTULA RECURVATA.

Tortula caule subnullo, foliis erecto-patentibus lanceolatis acutis marginibus superne recurvis, nervo crasso in mucronem brevem excurrente, seta elongata, capsula cylindracea, operculo breviusculo conico-cylindraceo. (TAB. CXXX.)

HАB. In territorio coloniali Capitis Bonæ Spei, in regione Roggeveld, inter Jakhals Fonteyn et Kuylenberg :-terrestris, in campis aridis, rara. D. Burchell.

Caules laxe cæspitosi, brevissimi, simplices. Folia pallide viridia, inferiora fuscescentia, erecto-patentia, lanceolata, perichatialia lineari-lanceolata, carinata, acuta, margine superiore recurvo, nervo crasso in mucronem brevem excurrente instructa. Seta sesquiuncialis, gracilis, flavo-rufescens. Capsula longa, cylindracea, rufo-fusca. Operculum breviusculum, conico-cylindraceum, obtusum. Peristomium pallide rufescens.

In this species the margins of the leaves are strikingly recurved, but not revolute as in T. pilifera (Musc. Exot. TaB. XII.) and in the European T.revoluta, nor are the stems elongated and branched. Some of the specimens of Barbula obtusifolia (Schwaegr.) are indeed described as having the stems nearly as short as in the present plant, and the leaves bearing the appearance of being recurved at the margins : but Schwaegrichen assures us that the margins are in reality thickened; moreover, the apices are in that species very obtuse, the fruitstalk is short, and the operculum long and subulate.

Fig. 1, plants, nat. size. Fig. 2, single plant. Fig. 3, leaf. Fig. 4, inferior ditto. Fig. 5, perichætial ditto. Fig. 6, apex of leaf seen from behind. Fig. 7, capsule and peristome. Fig. 8, operculum.-magn. 
Trib cxis.

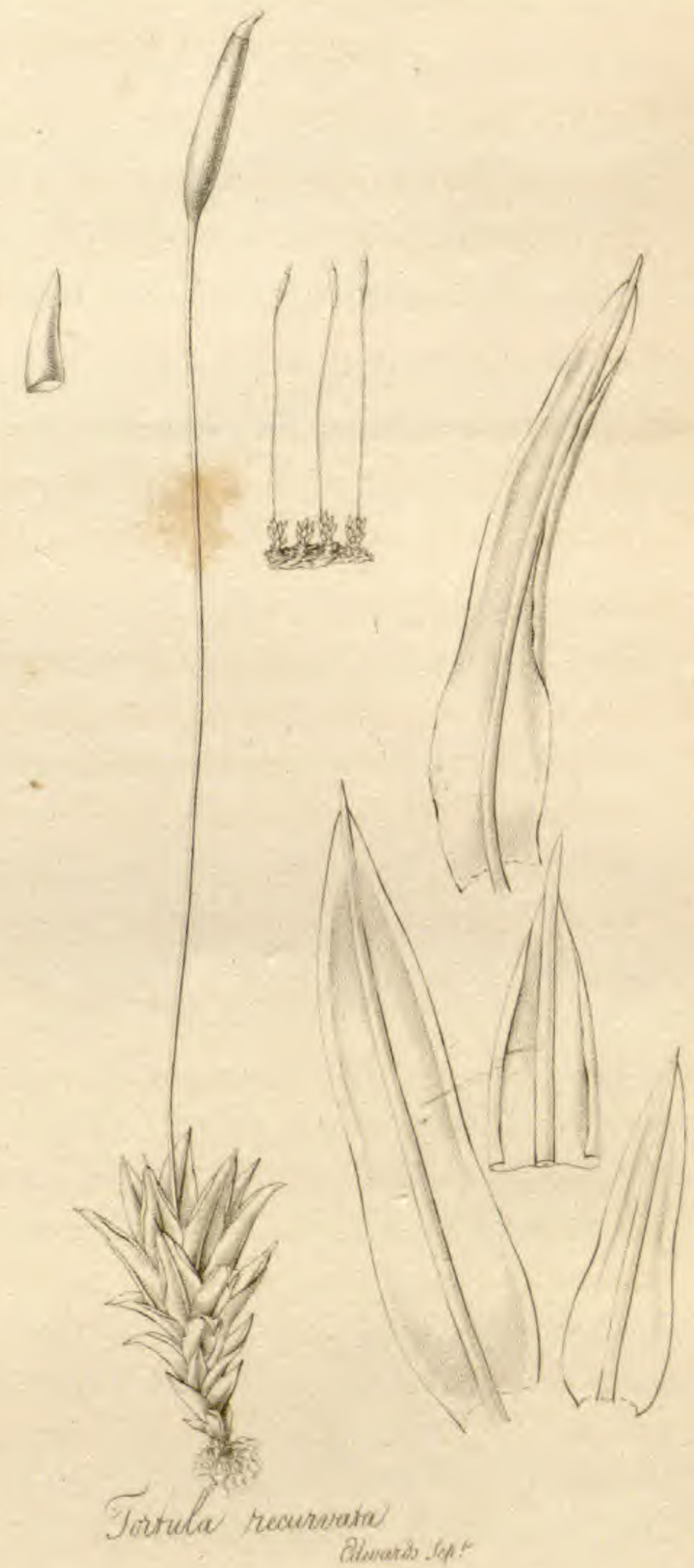


Fol. R27.2.
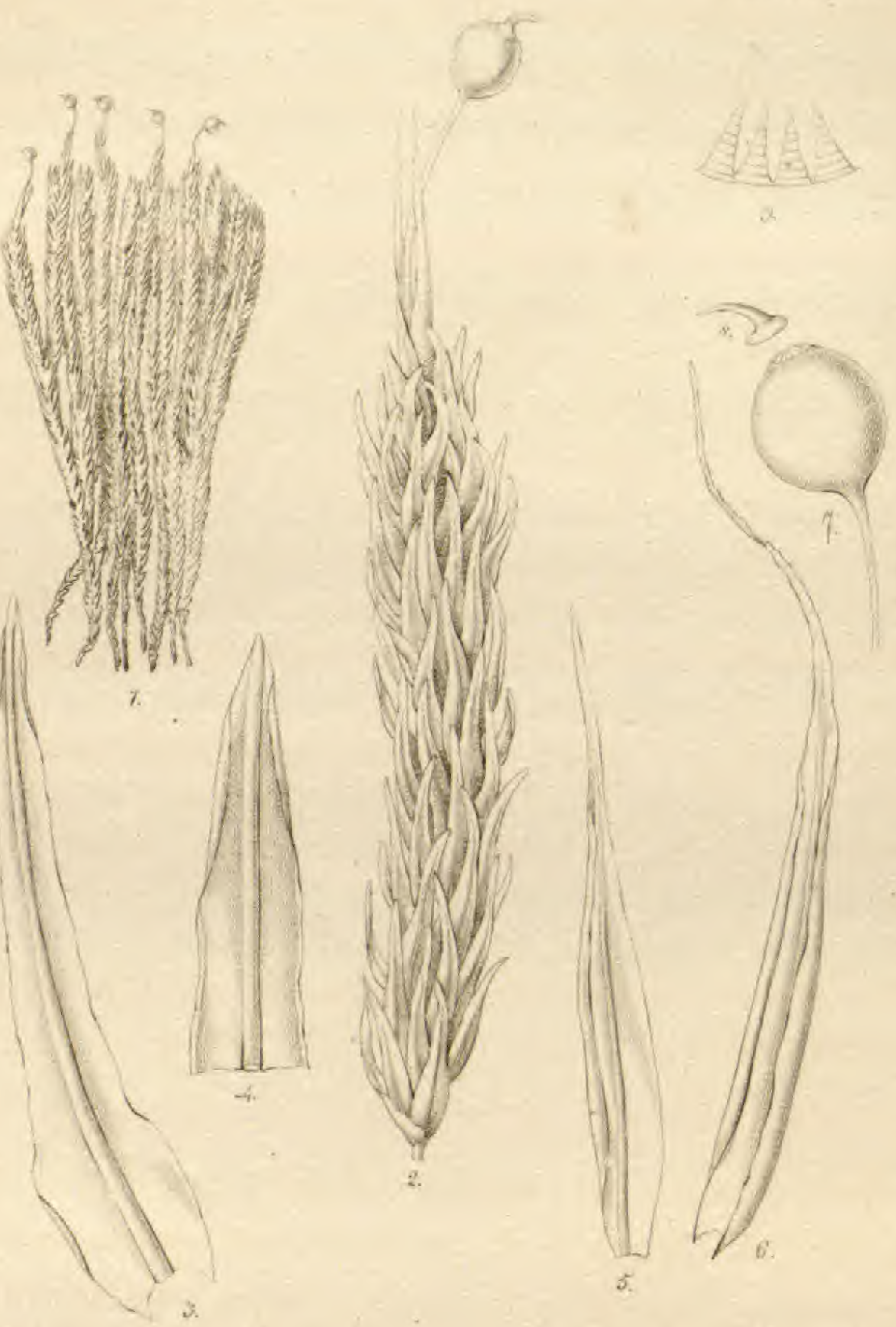

Majora pimnibonis.

carperiols Softo 


\section{WEISSIA POMIFORMIS.}

Weissia caule cæspitoso elongato subsimplice, foliis lineari-lanceolatis suberectis, perichætialibus subulatis convolutis, seta paululum exserta, capsula sphærica, operculo curvirostrato. (TAB. CXXXI.)

$\mathrm{H}_{\mathrm{AB}}$. In rupibus humidis soli et tempestati expositis, montium altissimorum ad locum Mountain Station dictum, rivulo Krombeks vicinum, et alibi in jurisdictione Zwellendam, territ. C. B. S., hic illic obvia, sed raro cum fructificatione invenienda. D. Burchell.

Caules bipollicares, cæspitosi, erecti, simplices vel ramosi. Folia flavo-viridia, dense imbricata, suberecta, planiuscula, paululum flexuosa, siccitate tortuosa, e basi latiore lineari-lanceolata, acutiuscula, integerrima, sub summa lente marginata, margine pallido, superne parum incurva, nervo valido ad apicem usque attingente : sulstantia compacta, opaca, basi solummodo teneriore. Perichatialia membranacea, longe subulata, circa setam convoluta. Seta perichætio paulo longior, erecta vel modice curvata. Capsula exacte sphærica, lævis, flavo-fusca: ore parvo rufescente. Operculum rostratum, rostro deflexo. Peristomium e dentibus 16, latiusculis, rufis, integris, transversim striatis.

This curious plant, though having so much the habit and the spherical capsule of a Bartramia, has nevertheless a simple peristome. Uuacquainted however with the calyptra, I place it with some degree of doubt amongst the Weissia. In the form of the capsule it approaches W. Martiana (TAB. CIV. of this work) and $W$. nigrita, from both of which in other respects it is widely different.

Fig. 1, tuft of plants, nat. size. Fig. 2, portion of a stem with its fructification. Fig. 3, leaf. Fig. 4, extremity of ditto. Fig. 5 and Fig. 6, perichætial leaves. Fig. 7, capsules. Fig. 8, aperculum. Fig. 9, teeth of the peristome,-magn. 


\section{Musci Exot I I.-Burchelliani.}

\section{. BARTRAMIA QUADRATA.}

Bartramia caule elongato vage ramoso, foliis patentibus subulatis flexuosis rigidis serrulatis, seta longa flexuosa, capsula quadrata sulcata. (TAB. CXXXII.)

HAB. In saxis humectatis umbrosis, ad scaturigines, in acumine montis altissimi Post-lerg dicti, prope pagum Georgii in regione Auteniqualand, C. B. S. rara. D. Burchell.

Caules laxe cæspitosi, erecti, flexuosi, rigidi, superne ramosi, inferne præcipue tomento fusco obsiti. Folia flavescentia, subdistantia, horizontaliter patentia, subsquarrosa, rigidiuscula tamen flexuosa, subulata, planiuscula, margine serrulata, nervo ad apicem attingente instructa. Seta terminalis, pollicaris, flexuosa. Capsula erecta vel inclinata, quadrata, sulcata, medio contracta. Operculum planiusculum. Peristomium non vidi; sed plantæ habitus omnino Bartramice.

Among the Bartramiae hitherto discovered, it would be difficult to say to which the present one approaches the nearest :-perhaps to B. patens of Schwaegrichen (B. squarrosa of Turner); but that species has the leaves remarkably straight, and neither that nor any other which I am acquainted with has a capsule at all like the one here figured.

Fig. 1, plants, nat. size. Fig. 2, portion of the stem and leaves. Fig. 3, leaves. Fig. 4, capsule,-magn. 
Fub cxixay

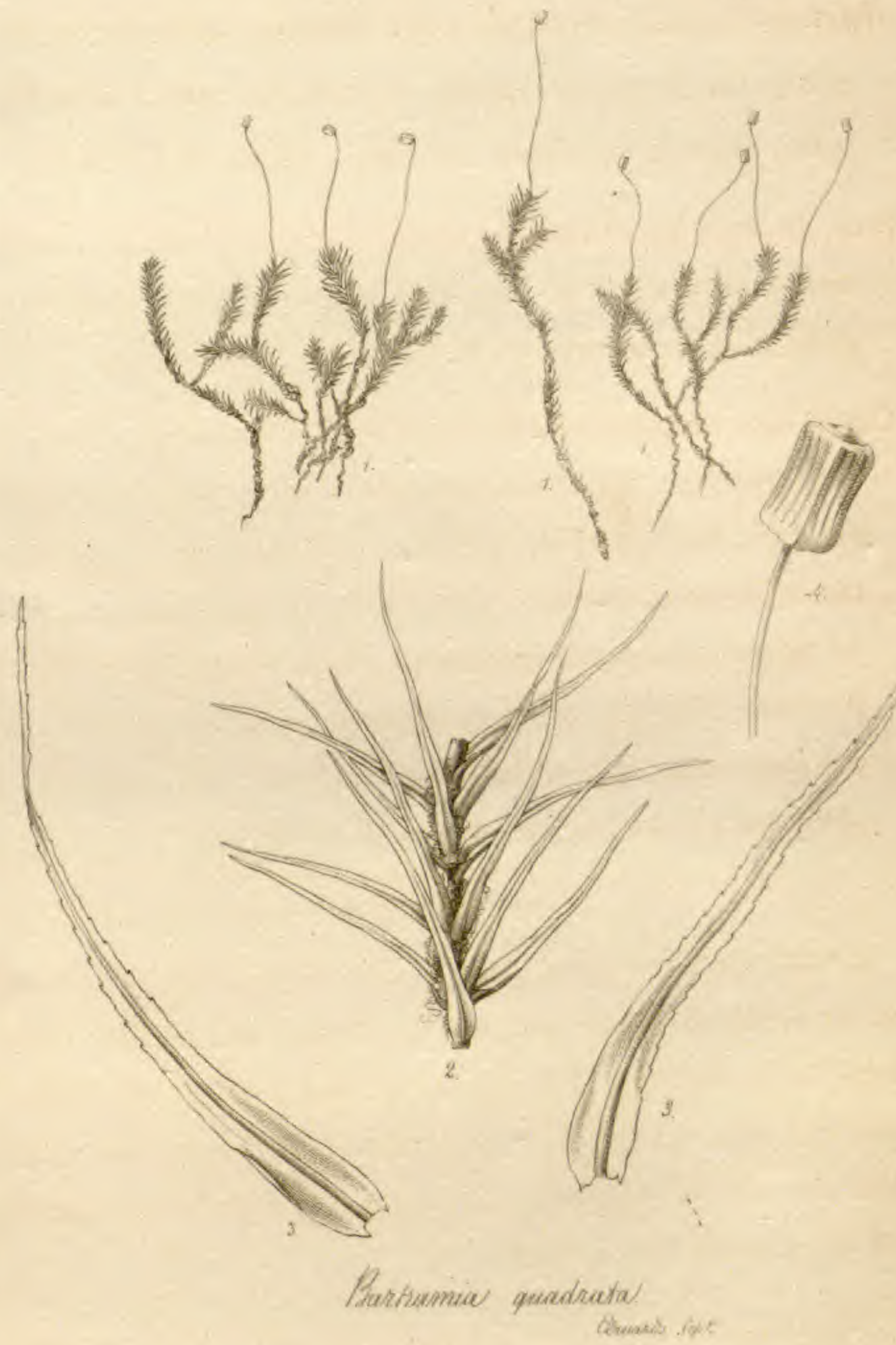


Tab coxixyz.

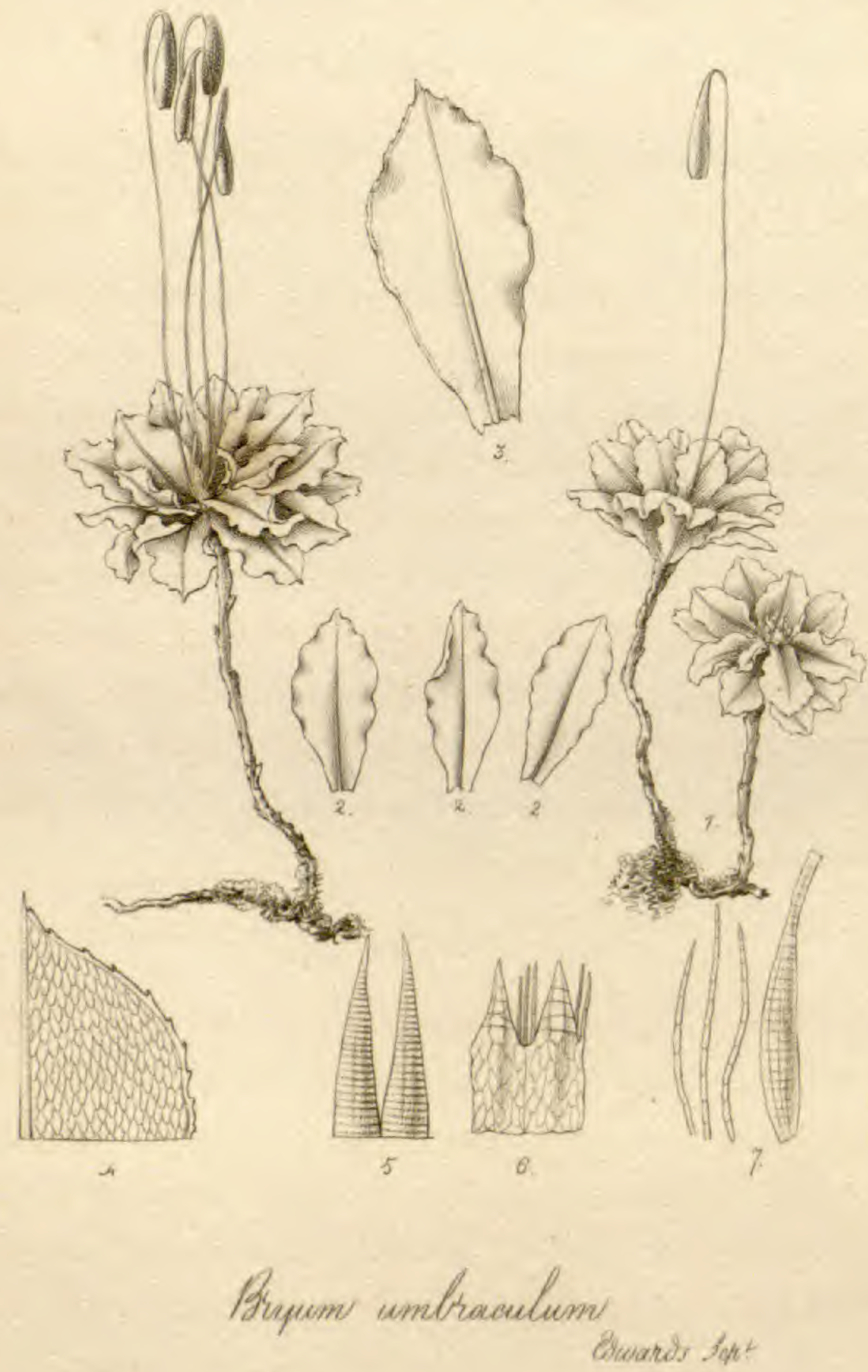




\section{BRYUM UMBRACULUM.}

Bryum caule elongato, foliis obovatis acutis marginatis undulatis serratis, nervo excurrente, capsula oblongocylindracea pendula. (ТАв. CXXXIII.)

Bryum Umbraculum. Burchell MSS.

$\mathrm{H}_{\mathrm{AB}}$. Terrestre, in umbrosis sylvarum densarum regionis Auteniqualand Africæ meridionalis; satis copiose. D. Burchell.

Caules inferne repentes, tomento fusco obsiti, ramosi, ramis erectis bipollicaribus, flexuosis, apice solummodo foliosis. Folia prægrandia, stellatim disposita, horizontaliter patentia, luridoviridia, inferne purpurascentia, obovata, acuta, undulata, marginata, minute serrata, nervo ultra apicem in apiculum brevem producto. Sulstantia satis crassa, areolis parvis oblongis reticulata. Setre solitariæ vel non raro 3 ad 5 ex eodem caule, subpollicares, rufæ. Capsula oblongo-cylindracea, pendula, intense rufo-fusca. Peristomium ext. dentibus luteo-fuscis, int. membrana reticulata, sedecim-dentata, dentibus perforatis, cum ciliis 2 vel 3 interpositis.

Were it not for the margined leaves which are but faintly serrated, and the very long almost cylindrical capsule, it would be hard to distinguish this species from Bryum roseum. These characters are however constant, and must surely be considered sufficient to constitute it a distinct plant. The leaves are perhaps the largest of any known moss. In the centre of some of the foliage I find the Hedwigian female flowers, containing, besides the pistils, jointed filaments, both of a reddish brown colour.

Fig. 1, 1, plants, and Fig. 2, 2, 2, leaves, nat. size. Fig. 3, leaves. Fig. 4, portion of a leaf. Fig. 5, ext. teeth of peristome. Fig. 6, portion of inner ditto. Fig. 7, parts of the female flower. 


\section{DICRANUM FRAGILE.}

Dicranum caule elongato ramoso, foliis subsecundis subulato-setaceis, serratis, siccitate subflexuosis, perichætialibus basi vaginatis, capsula erecta cylindracea. (TaB. CXXXIV.)

HAB. In Nepaul legit Hon. D. Gardner, et ad J. Banks Baronetum communicavit Gul. Wallich, M. D. 1791.

Caules 3-4-pollicares, cạspitosi, erecti, flexuosi, tomento fuscoferrugineo undique obsiti, ramosi. Folia luteo-viridia, subdistantia, subsecunda, patentia, curvata, siccitate flexuosa, insigniter fragilia, subulato-setacea, margine serrata, nervo ad apicem attingente instructa. Substantia mollis, laxius reticulata. Perichcetialia basi vaginata. Seta sesquiuncialis, erecta. Capsula erecta, cylindracea, flavo-fusca. Calyptra operculumque desunt. Peristomium e dentibus 16, brevibus, rubris, transversim striatis, ultra medium fissis, segmentis subinæqualibus.

This moss comes near in general appearance to some of the small varieties of Dicranum scoparium, and perhaps still more to $D$. Scottianum. It is remarkable, however, in having a downy substance on the whole length of the stalk, leaves of a much softer nature than the species just mentioned, narrower, and very strongly serrated, curved when moist, only slightly flexuose when dry, and then exceedingly brittle.

Fig. 1, tuft of plants, nat. size. Fig. 2, portion of a stem with leaves. Fig. 3, leaf. Fig. 4, perichætium. Fig. 5, leaf of perichætium. Fig. 6, capsule. Fig. 7, teeth of the peristome. 


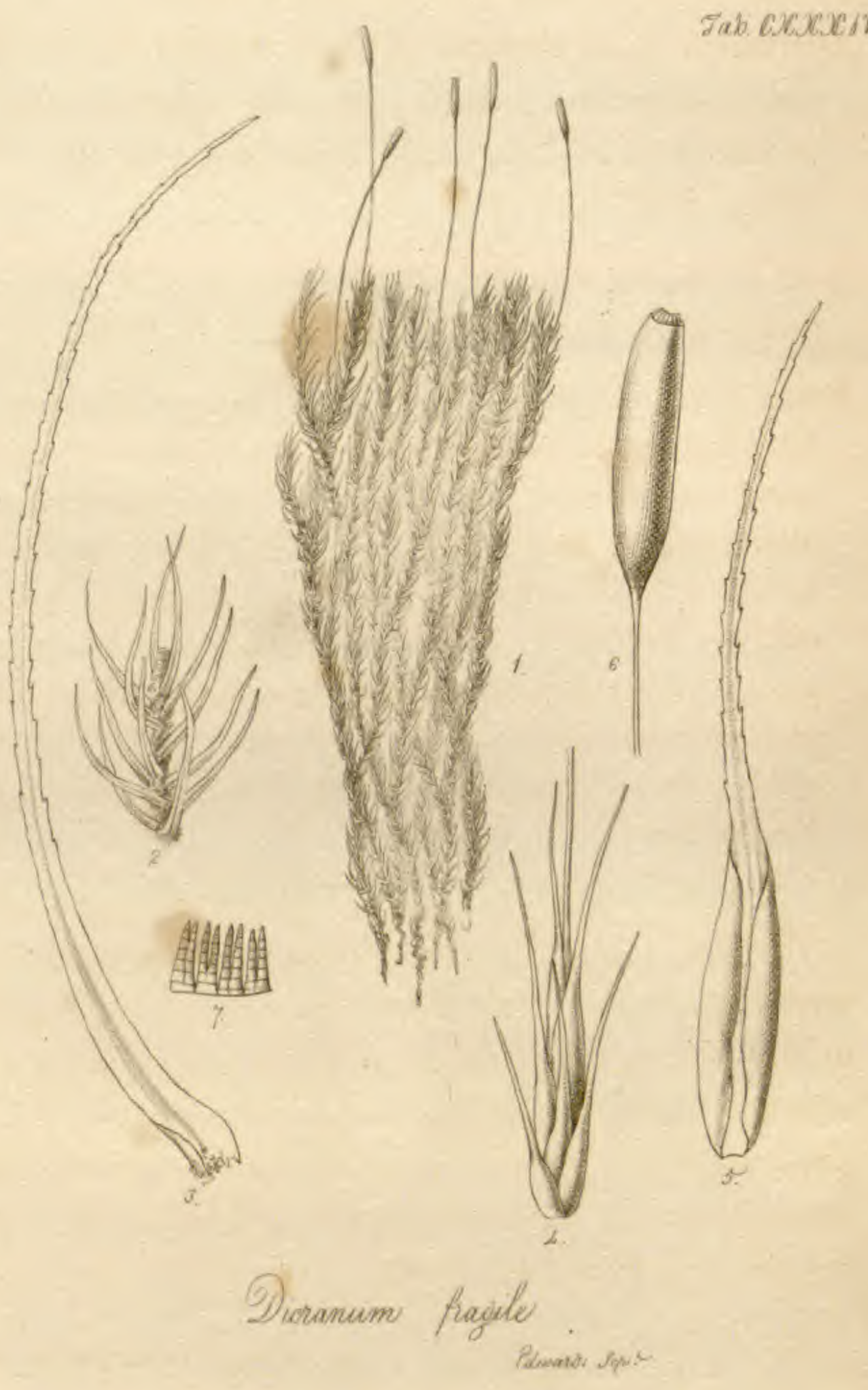




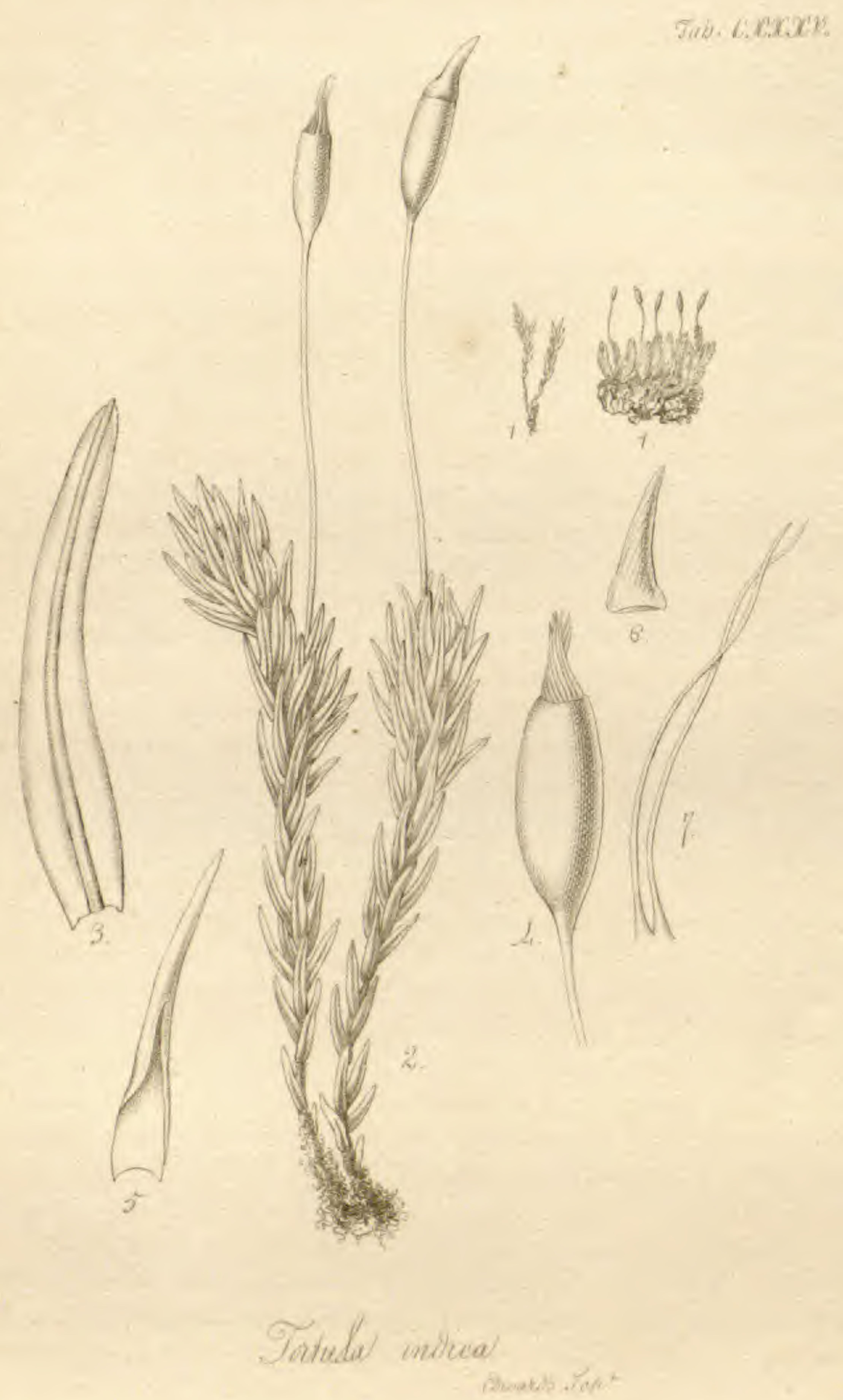




\section{TORTULA INDICA.}

Tortula caule breviusculo subramoso, foliis lineari-oblongis erectis subapiculatis siccitate crispatis, capsula oblonga, operculo acuminato. (ТАB. CXXXV.)

Trichostomum indicum. Willd. in Bot. Mag. v. 4 . p. 7.t. 1. (fide Schwaegr.) Schwaegr. Suppl. v. 1. p. 242 . t. 36 .

НАв. In India orientali. Röttler. In muris Horti Botanici Calcuttæ, Indiæ orientalis. Gul. Wallich, M.D.

Caules in cæspitibus latis, semiunciales, erecti, innovationibus præcipue ramosi, superne plerumque incrassati. Folia dense imbricata, atro-viridia, erecta, mollia, lineari-oblonga, obtusa, margine subrecurvo, nervo satis crasso concolore ultra apicem in apiculum perbrevem desinente percursa, siccitate tortilia. Perichretialia reliquis similia, sed longiora. Seta bi-trilinearis flava. Capsula oblonga flavo-fusca, ore rufo. Operculum capsula brevius, flavescens, acuminatum. Calypira pallide fusca, lateraliter fissa. Peristomium breviusculum, e ciliis longis filiformibus spiraliter tortis, intense rubris, inarticulatis, basi per paria conjunctis.

Patches of this plant, eight or ten inches in diameter, were gathered on brick walls surrounding the Botanic garden of Calcutta by my kind friend Dr. Wallich, who has the direction of that establishment, and who has not only exerted himself to collect cryptogamic plants for me, but has induced the Honourable Edward Gardner to do the same in the rich and distant province of Nepaul, where he is resident at the court of the Rajah of Kalmondu; so that through his means I am in possession of some very curious mosses from these countries, which $l$ shall hasten to lay before the public.

On taking off the operculum of the species now under consideration, I find the upper part of the peristome mostly removed with it, when the remains will naturally give the idea of a Didymodon, or according to the Hedwigian system a Trichostomum; and it is this circumstance which has probably deceived Schwaegrichen, and induced him to figure the peristome incorrectly. The erect and linear-oblong leaves distinguish this at once from all the known species of Tortula.

Fig. 1, tufts of plants, nat. size. Fig. 2, single plant. Fig. 3, leaf. Fig. 4, capsule and peristome. Fig. 5, calyptra. Fig. 6, operculum. Fig. 7, teeth of the peristome.-magn. 


\section{OCTOBLEPHARUM SERRATUM.}

Octoblepharum caule erecto ramoso, foliis erecto-patentibus ovatis serratis cuspidatis, capsula pyriformi, operculo hemisphærico apiculato, calyptra mitriformi longe pilosa. (ТАв. CXXXVI.)

Octoblepharum serratum. Bridel Musc. Suppl. v. 1 . p. 86.

Orthodon. Bory de St. Vincent. (fide Beauv.)

Bryum orthodontum. Beauv. Prodr. d'Atheog. p. 48. Splachnum squarrosum. Hook. in Linn. Trans. v. 10. p. 308 . t. 26 . f. 2.

HAB. In insula Bourbon ad terram humidam prope truncos aversos. Bory de St. Vincent. In Nepaul abunde legit D. Buchanan, M.D. et Hon. D. Gardner.

Caules unciales, crespitosi, inferne dense ferrugineo-tomentosi, erecti, subranosi. Folia lutescente-viridia, undique laxe disposita, erecto-patentia, apice sæpe tortuosa, ovata vel ovatolanceolata, paululum carinata, margine argute serrata, nervo ultra apicem in acumen longum producto instructa. Perichatialia paululum longiora. Seta unguicularis, terminalis, crocea. Capsula crocea, pyriformis, vel, si mavis, ovata, apophysi obconica capsula paululum longiore insidens. Calyptra capsula brevior, mitriformis, membranacea, pellucida, albida, basi ventricosa, quadrifida, superne attenuata, superficies pilis longis, flexuosis, articulatis, patentibus albis. Operculum hemisphæricum, apice in acumen angustum attenuatum. Peristominm. e dentibus 8 , lanceolatis, humectate incurvis, siccitate erectis, subcoriaceis luteis, transversim striatis, atque linea media longitudinali obscure notatis.

Having fallen into an error in the Linnæan Trans?ctions, where I have described the teeth of this moss as 16 per paria approximatis, whereas they are decidedly but 8 with a middle longitudinal line, and having become possessed of noble specimens with every part of the fructification in the most complete state, I willingly publish another description and figure of it. The eight teeth and the terminal fruitstalk constitute this plant an Octoblepharum. I an donbtful, however, whether O. allidum has a mitriform calyptra ; and if it have, I should propose that the present subject be separated from it on that account, preserving to it Bory de St. Vincent's name of Orlhodon. The calyptra is a very striking object, and rendered more so by the long hairs spread'ng every way. The whole plant inclines remarkably to yellow.

Fig. 1, plants, nat.size. Fig. 2, single plant. Fig.3,3, leaves. Fig. 4, capsule. Fig. 5, operculum. Fig.6, calyptra. Fig. 7, hair of calyptra. Fig. 8, peristome, as seen when dry.-magn. 
sab.cxacevy.

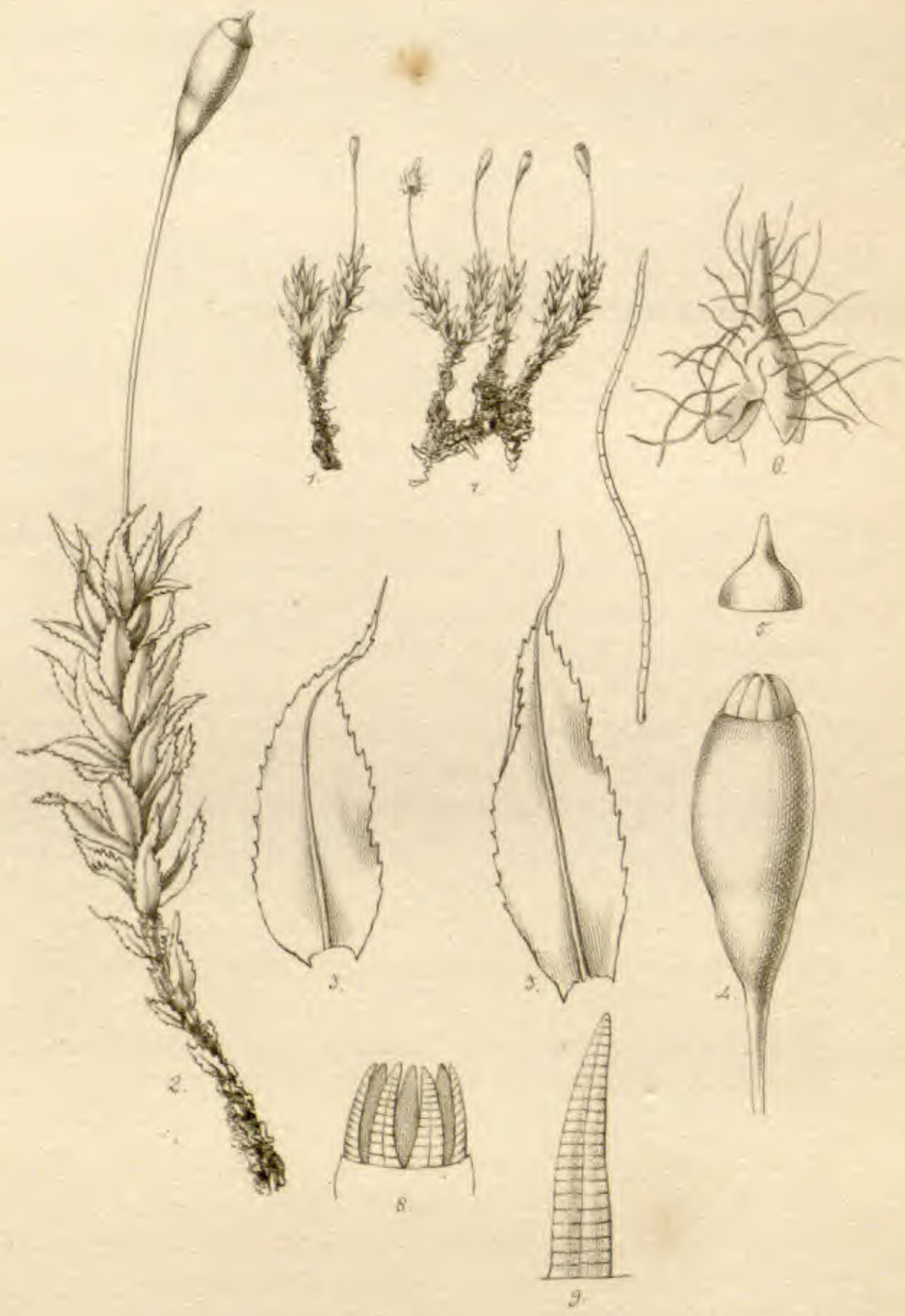

Qefolepharum sonatum

Druath sipe: 
Tab. cxxrvII

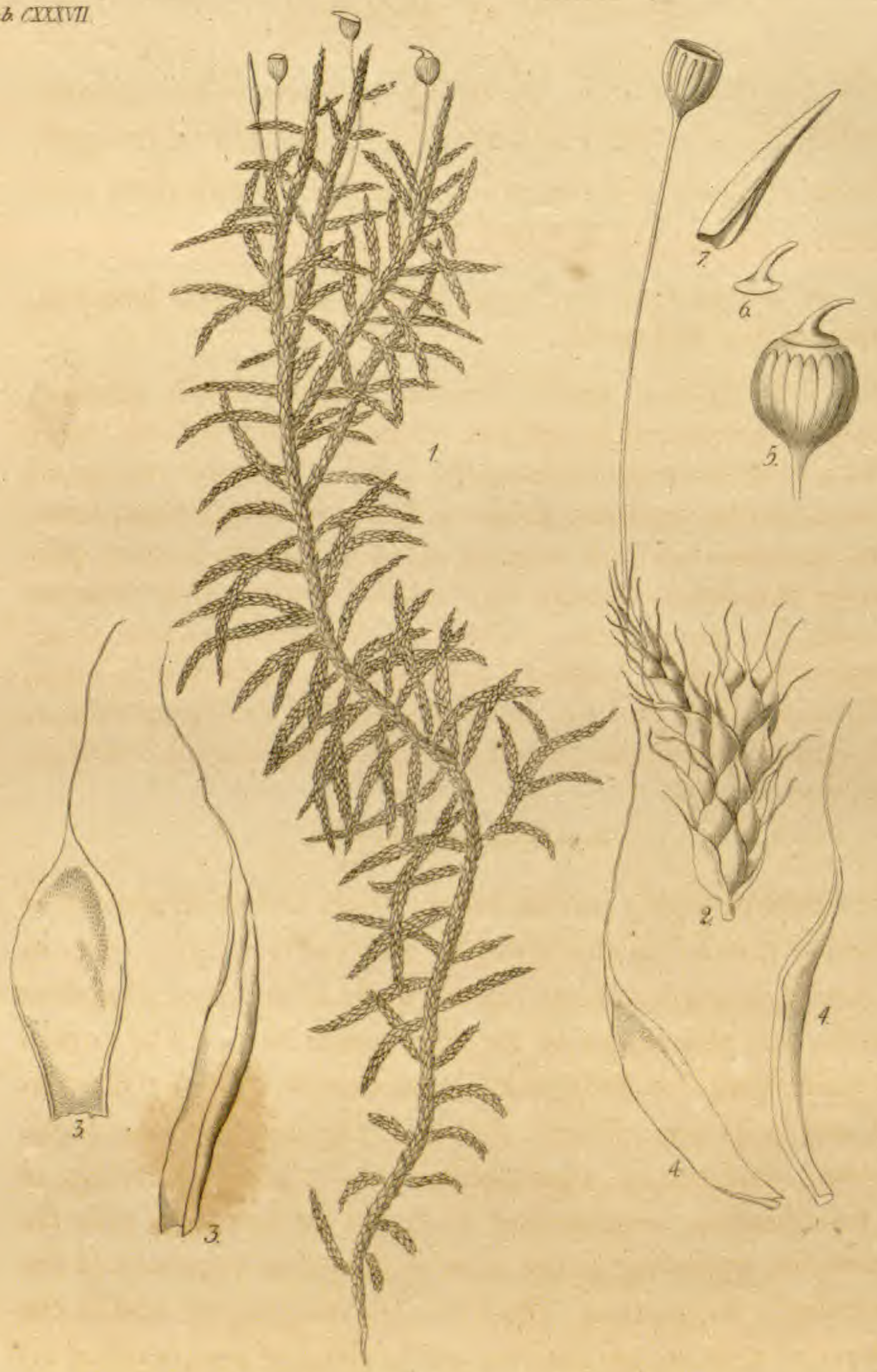

Hedurigia thumbldtiv 


\section{HEDWIGIA HUMBOLDTII.}

Hedwigia caule erecto, pinnatim ramoso, foliis undique imbricatis obovatis concavis enervibus piliferis integerrimis, capsula globosa sulcata, operculo subulato curvato. (TAB. CXXXVII.)

$\mathrm{H}_{\mathrm{AB}}$. In monte Quindiu, locis frigidis, altit. 1580 hexapod. Humbnldt et Bonpland.

Caules 3-6-unciales, erecti, flexuosi, ramosi, ramis pinnatis, pinnis approximatis patentibus vel decurvis, uncialibus, teretibus, basi apiceque attenuatis. Folia undique imbricata, densa, erecta, appressa, concavi, obovata, integerrima, enervia, margine inferiore recurvo, apice in acumen longum piliforme flexuosum, fuscum, rigidum desinentia. Color obscure viridis, basi aurantiacus. Perichatialia fere omnino ut in reliquis sed magis aurantiaca. Seta lateralis, uncialis, rufo-fusca. Capsula erecta, globosa, rufo-fusca, sulcata siccitate præcipue. Calyptra dimidiata. Operculum rostro capsula sub-breviore, oblique curvato.

The present highly curious Moss, which, no less on account of its beauty than of its characters so different from every other in the family, is worthy of bearing the name of the most illustrious traveller and philosopher of the age, has in its mode of growth the appearance of a Sphagnum, in its capsule that of a Bartramia, and in its general habit that of a Hypnum. The capsule, however, destitute of a peristome, and the lateral situation of the fructification, require that it should be arranged with the Hedwigia, according to the ideas of the genus expressed in the Muscologia Britannica. The leaves, in their texture and in the absence of a nerve, are not very unlike those of Anictangium ciliatum and imberbe.

Fig. 1, plant, nat. size. Fig. 2, portion of the stem and fructification. Fig. 3, leaves. Fig. 4, perichætial leaves. Fig. 5, capsule. Fig. 6, operculum. Fig. 7, calyptra.-magn.

VoL. II. 


\section{DICRANUM CONCOLOR.}

Dicranum caule elongato ramoso, foliis undique vergentibus e basi anguste lanceolata longissime subulato-setaceis subintegerrimis, nervo latissimo, seta flexuosa, capsula ovata striata strumosa, calyptra fimbriata. (TAB. CXXXVIII.)

$\mathrm{H}_{\mathrm{AB}}$. In alto de Aranda, locis frigidis, prope Pasto, (regnum Novum Granatense) altit. 1560 hexapod. Humboldt et Bompland.

Caules bi-triunciales, erecti, flexuosi, hic illic dichotome divisi. Folia undique vergentia, planiuscula, siccitate etiam e basi anguste lanceolata, longissime subulato-setacea, flexuosa, pallide viridia, apicem versus subserrulata, nervo latissimo paginæ fere totam partem occupante. Perichretialia reliquis similia, sed lateribus involutis, Setæe aggregatæ, flexuosæ vel curvatæ. Capsula flavo-fusea, inclinata, oblongo-ovata, sulcata, basi strumosa. Operculum conico-subulatum rufo-fuscum. Calyptra dimidiata, basi elegantissime ciliata. Peristomium dentibus 16 , incurvis, rufis, fissis.

The species here described belongs to a curious family of Dicramum, along with $D$. flexuosum, D. cygneum, and D. introflexum, all agreeing in general habit, in the broad nerve of the leaf, and in the ciliated border of the calyptra. From the former of these it differs in the much longer and twisted nature of the leaves; from the two latter, in the striated and strumose calyptra; and still further from the last-mentioned species, in having the tips of the leaves of one uniform colour with the leaves themselves, and not at all diaphanous.

Fig. 1, 1, plants, nat. size. Fig. 2, leaf. Fig. 3, leaf of perichætium. Fig. 4, portion of ditto magnified to show the nerve. Fig. 5, capsule. Fig.6, annulus. Fig. 7, operculum. Fig. 8, calyptra.-magn. 
$T a b, c \times x \times$ NyI.

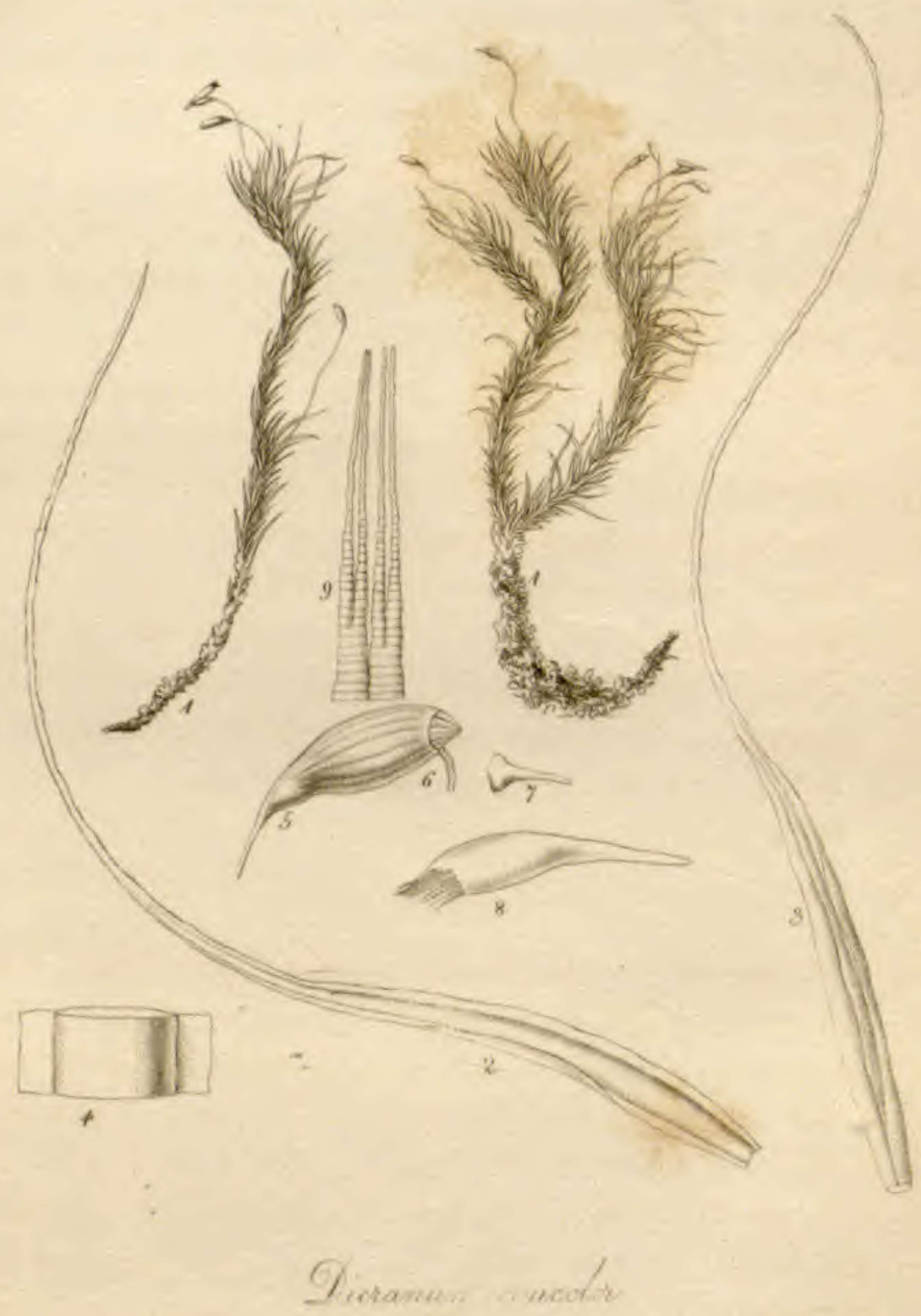


Tab. cxocky.

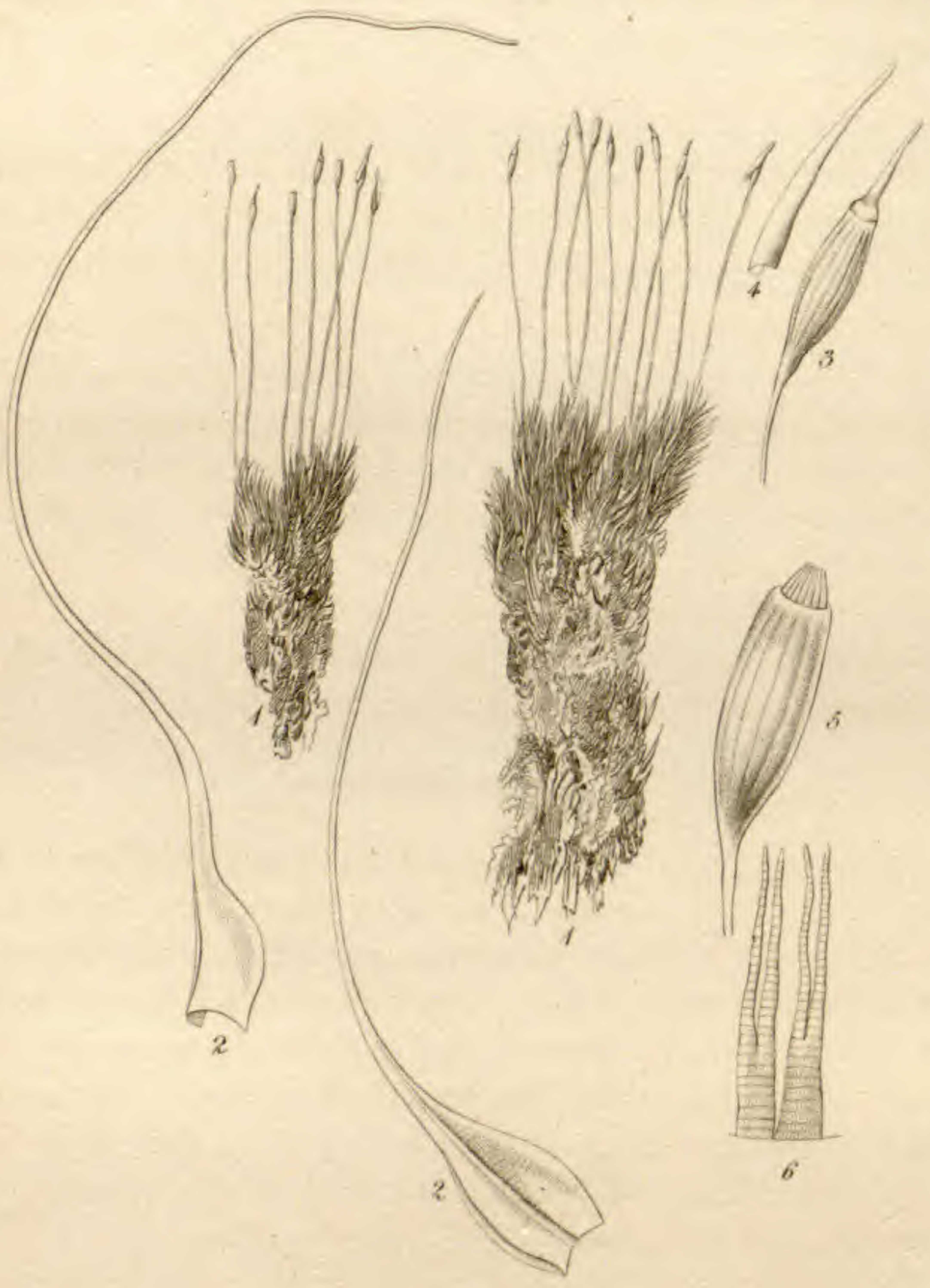

Diranum congivetum 


\section{DICRANUM LONGISETUM.}

Dicranum caule subelongato simpliciusculo, foliis falcato-secundis e basi late ovata longe tenuiterque subulato-setaceis, seta longa, capsula erecta oblonga striata, struma nulla, operculo longe subulato. (ТАB. CXXXIX.)

$\mathrm{H}_{\mathrm{AB}}$. In temperatis regni Novi Granatensis, in sylvis prope $\mathrm{Fu}$ sagasaga, alt. 1030 hexap., atque in apricis frigidis montis Chimborazo, altit. 2430 hexapod. Humboldt et Bonpland.

Caules cæspitosi, subelongati, inferne fibris tomentosis obsiti. Folia flavo-viridia, bi- trilinearia, undique inserta, falcato-secunda, e basi late ovata, longe tenuiterque subulata, setacea, subflexuosa, vix apice serrulata, nervo satis angusto. Perichaetialia basi lanceolata vaginata. Seta stricta. Capsula erecta, ovato-oblonga, flavo-fusea, striata, struma nulla. Operculum subulatum, rectum, capsulam longitudine æquans. Calypira dimidiata, pallide fusea. Peristomium e dentibus 16 , infra apicem fissis, rufo-fuscis, transversim striatis.

There are few genera whose species are so difficult to be distinguished from one another as those of Dicranum. The present instance happily affords an exception. The capsule has no stru$\mathrm{ma}$; and this circumstance, together with the general figure of the leaves and their direction, indicates some affinity with $D$. heteromallum; but in this the capsule is erect, or very nearly so; and when attentively examined, the leaves, in their great length and shape, will furnish sufficient marks of discrimination both from that and every other species of the genus.

The habit of the plant is not much unlike some species of $C y$ nontodium, and the leaves approach those of C. longirestre, though the stems and the fruitstalks are widely different, and our species has truly the teeth of a Dicranum.

Fig. 1, 1, plants, nat. size. Fig. 2, leaves. Fig. 3, capsule with operculum. Fig. 4, calyptra. Fig. 5, capsule with the peristome. Fig. 6, portion of the peristome.-magn. 


\section{DICRANUM DENSUM.}

Dicranum caule simpliciusculo, foliis lanceolato-subulatis integerrimis, nervo tenui, capsula ovata inclinata lævi absque struma, operculo longe rostrato curvato. (ТАB. CXL.)

$H_{A B}$. In crepidinibus montis Quindiu, regione temperata. Humboldt et Bonpland.

Caules densissime cæspitosi, semiunciales, erecti, subsimplices, inferne tomento fusco obsiti. Folia pallide viridia, undique imbricata, e basi late lanceolata, subulata, planiuscula, integerrima, nervo satis tenui et ad apicem attingente instructa. Sulstantia tenera, reticulata. Seta solitaria, semiuncialis. Capsula ovata erecta vel lenissime inclinata fusca, absque struma sed ad basin paululum contracta, lævis. Operculum subulatum, curvatum, capsula concolor, ejusdem longitudine. Annulus simplex. Calyptra dimidiata. Peristomii dentes 16, rufi, satis magni, transversim striati, ad dimidium et ultra longitudinem fissi.

Notwithstanding that the peristome of this moss prove it to be a true Dicranum, the natural habit of the plant has a great similarity to Weissia acuta of Hedwig; insomuch that without having recourse to a microscope-when the leaves will be found to differ both in form and texture-they will not readily be distinguished. In the genus to which it belongs, I know of no species with which it is likely to be confounded except D. cerviculatum, which, however, has an evident struma, much more subulate leaves, and a remárkably broad rierve.

Fig. 1, tufts of plants, nat. size. Fig. 2, single plant. Fig. 3, leaves. Fig. 4, capsule with its annulus and peristome. Fig.5, operculum. Fig. 6, teeth of the peristome.-magn. 
Tab. exs.

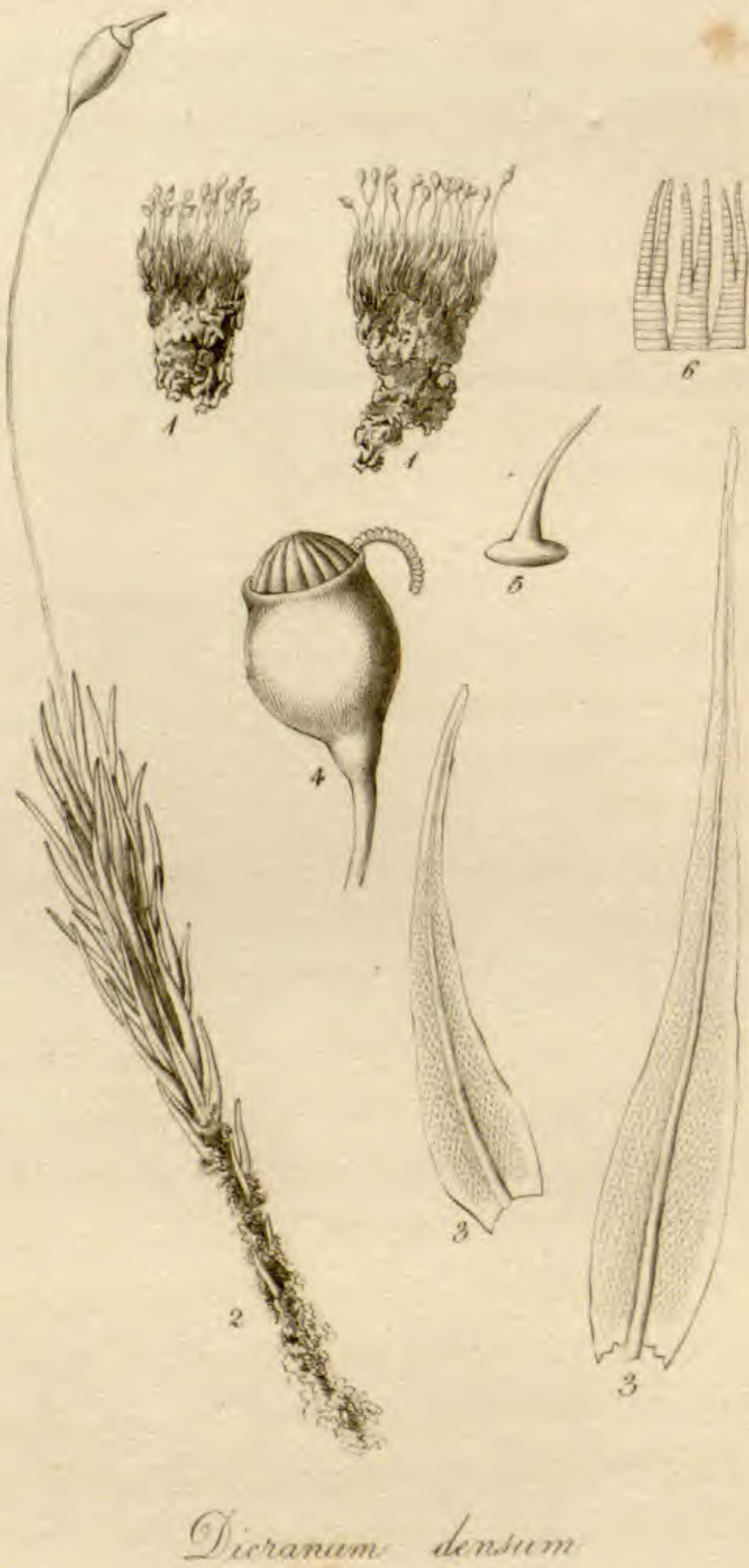





\section{DICRANUM VAGINATUM.}

Dicranum caule elongato ramoso, foliis laxis a basi longe vaginante subulatis vix apice serratis, nervo excurrente, capsula inclinata ovata absque struma, operculo longe subulato. (TAB. CXLI.)

HAB. In convallibus Andium Granatensium inter Almaguar et Pasto, altit. 1200-1500 hexapod. Humboldt ct Bonpland.

Caules laxe cæspitosi, fusco-tomentosi, bi-tri- ad 4-unciales, erecti, filiformes, flexuosi, bis terve dichotomi. Folia lurido-viridia, laxe imbricata, e basi lanceolata, undulata vaginante, subulata apice parum recurva, vix serrulata, nervo angusto in acumen longum producto. Seta terminalis, uncialis. Capsula erecta vel paululum inclinata, rufo-fusca, struma nulla. Operculum longe rostratum, curvatum. Calyptra dimidiata, pallide fusca. Peristomium rubrum, e dentibus 16, infra basin fissis, marginibus hispidis.

I know of no species of the genus with the leaves so remarkably sheathing in their lower half, and so subulate in the upper, as is the case with the present.

Fig. 1, 1, plants, nat. size. Fig. 2, portion of a plant with young fructification. Fig 3 and 4, leaves. Fig. 5, capsule. Fig.6, operculum. Fig. 7, calyptra. Fig. 8, teeth of the peristome. 


\section{Musci Exоті C1.-Humboldtiani.}

\section{JUNGERMANNIA FILICINA.}

Jungermannia caule erecto, pinnatim ramoso, foliis inæqualiter bilobis, lobis superioribus majoribus ovatis acutiusculis apice serratis; inferioribus minutis, subrotundatis, " conduplicatis ; stipulis obovato-quadratis, serratis, calycibus lateralibus oblongo-obcordatis, apiculatis.

(TAв. CXLII.)

Jungermannia filicina. Swarts. Prodr. Fl. Ind. Occ. p. 145. Fl. Ind. Occ. p. 1866. Schwaegr. Hist. Musc. Hepat. Prodr. p. 18.

НАв. In frigidis scopulosis montis Saraguru, prope Alto de Pulla, Loxam inter et Oñam, altitud. 1564 hexapodarum. Humboldt et Bonpland.

Planta cæspitosa, et (Swartzio teste) inter maximas species sui generis referenda. Radix repens, filiformis. Caules 4 - ad 6unciales, erecti, rigidi, pinnatim ramosi ; rami subunciales, horizontales, attenuati, simplices, vel hic illic iterum pinnati, ramulis brevibus. Folia superne imbricata, horizontalia, bifariam disposita, disticha, siccitate involuta, inæqualiter biloba; lobis supericribus multo majoribus, ovatis, acu tiusculis, subplanis, apice serratis; lobulis valde minutis, ovatorotundatis, conduplicatis, appressis, omnino integerrimis; stipulis obovato-subquadratis, apice serratis, marginibus lateralibus sæpe revolutis. Color saturate viridis. Folia perichætialia lobis lobulisque acuminatis, serratis. Stipule perichætiales bifidæ, segmentis acutis, serratis. Seta lateralis. Calyx oblongo-cordatus, trigonus, lævis, viridis ; ore apiculum tubulosum formante. Germen pyriforme; stylo longo terminatum.

Jungermannia filicina was first found by Dr. Swartz " in montibus altissimis Jamaica," and described by him in his Flora Indice Occidentalis; but no figure of it having ever appeared, I have thought right to subjoin one here; and I have done so the more willingly, since I have been so fortunate as to possess specimens with the fructification, which Swartz never saw. Its ramification is like that of Sertularia abietina; and when the plant is dry, the leaves are not very unlike the teeth of that zoophyte. Not only the mode of branching, but the shape of the leaves remove it from the rest of the species of the genus. Its nearest affinity among the described ones is perhaps $J$.dilatata and J. Tamarisii.

Fig. 1, plant, nat. size. Fig. 2, portion of a branch with fructification, upper side. Fig. 3, leaves and stipules, under side. Fig. 4, portion of a leaf. Fig. 5, fructification,-magn. 
Tab. cxest.
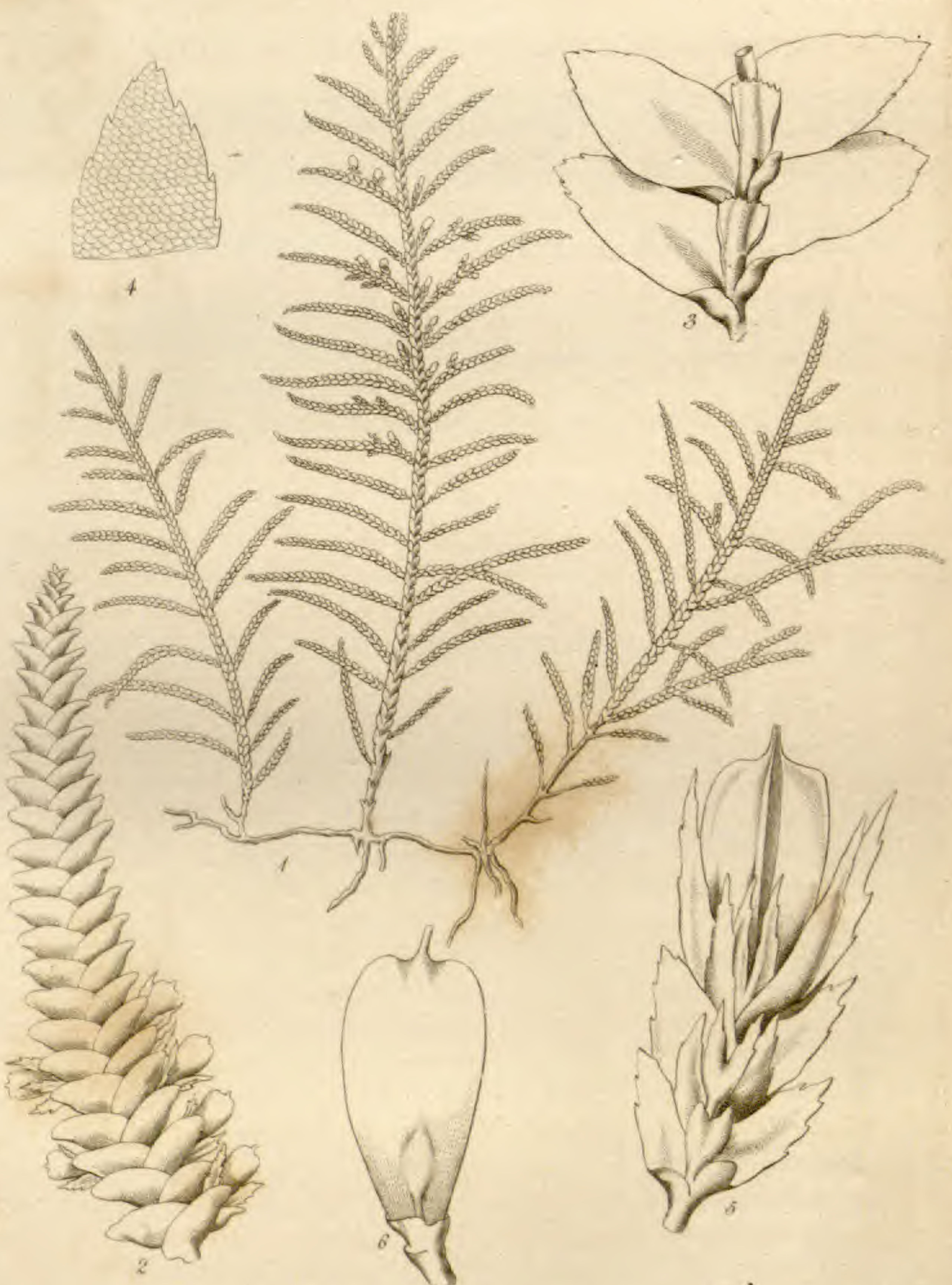

ressssaso है:

-

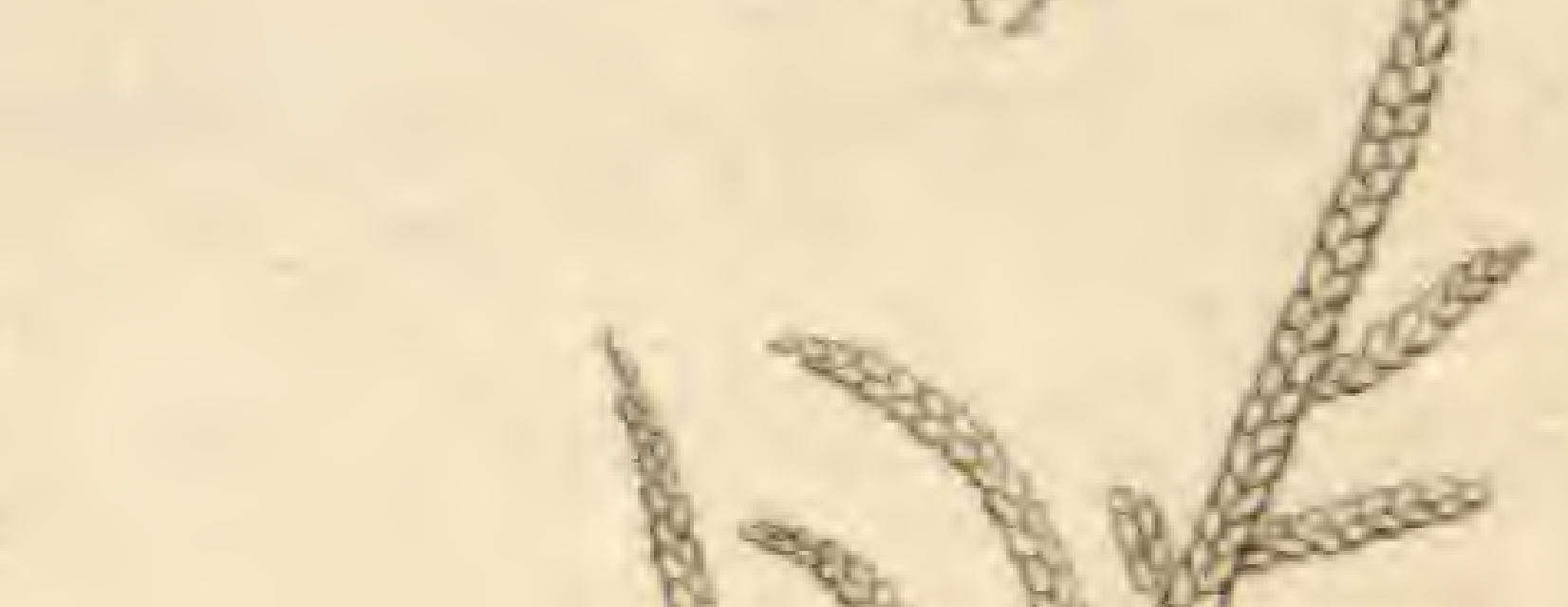

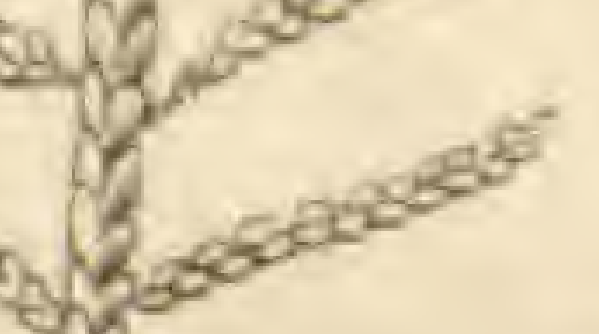
of

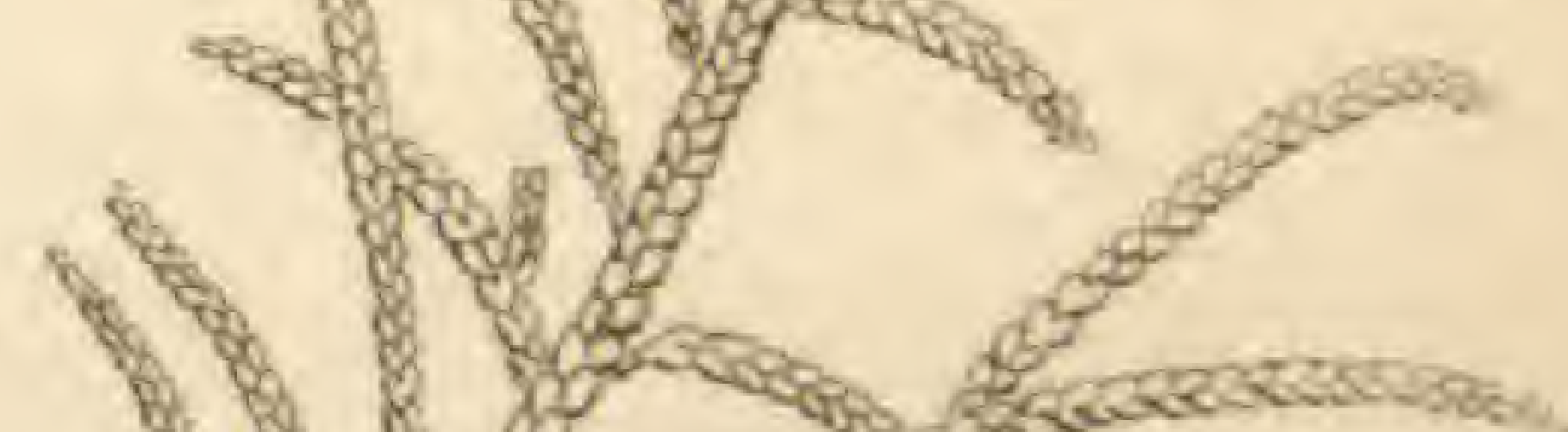

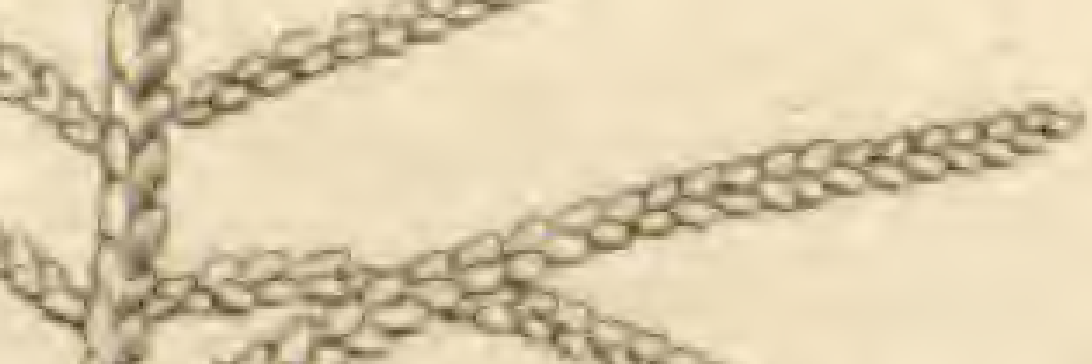
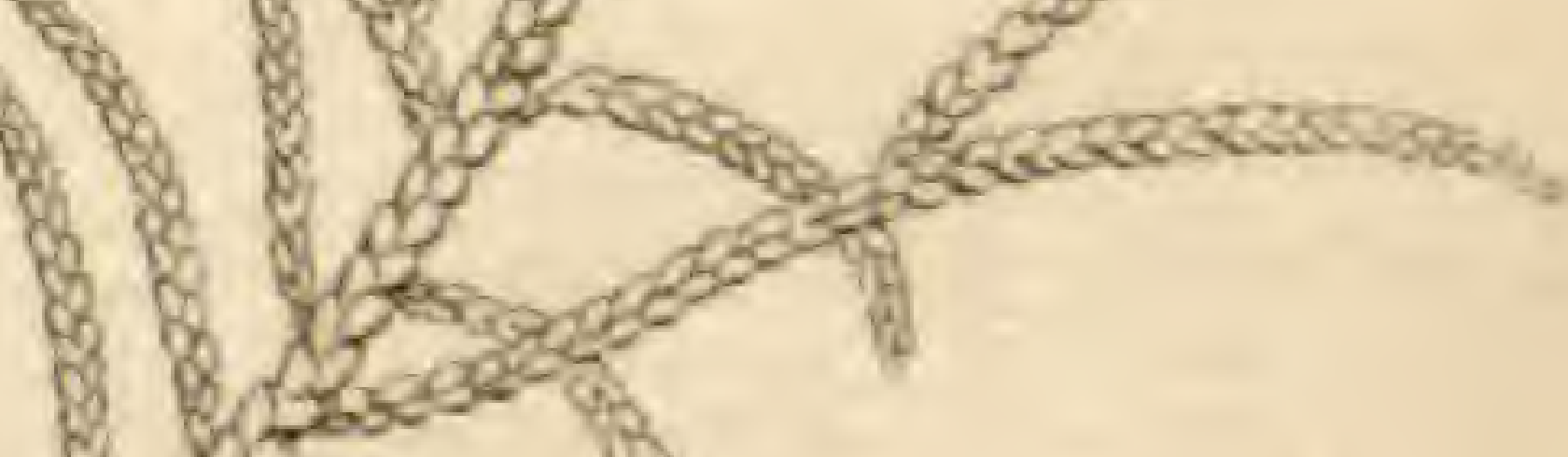
sab. cxsil.
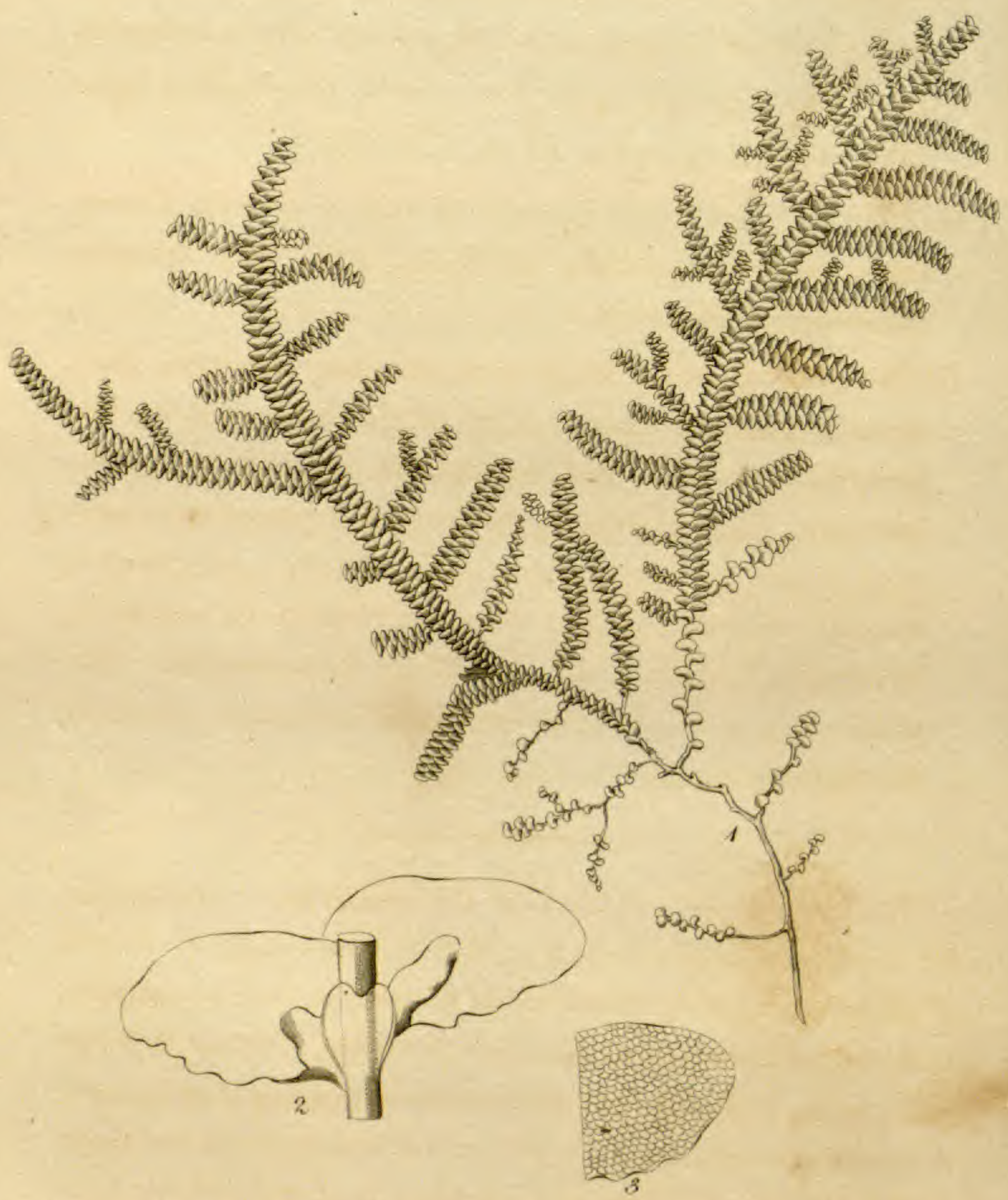

Tungermannia crispata 


\section{Musc e Exoті с1.-Humboldtiani.}

\section{JUNGERMANNIA CRISPATA.}

Jungermannia caule procumbente pinnatim ramoso, foliis bifariis integerrimis inæqualiter lobatis crispatis, lobis superioribus majoribus ovatis, inferioribus ligulatis, stipulis cordatis. (ТАв. CXLIII.)

$\mathrm{H}_{\mathrm{AB}}$. In umbrosis montis Quindiu ad radices Quercus Granatensis juxta la Guebrada de Torha, altit. 1050 hexapod. Humboldt et Bonpland.

Caules 3 ad 4 uncias longi, procumbentes, filiformes, fusci, flexuosi, pinnatim ramosi, primis alterne patentibus, hic illic pinnati iterum. Folia basi laxe disposita, reliqua dense, superne imbricata, bifaria, disticha, horizontaliter patentia, integerrima, biloba; lobis superioribus ovatis, obtusis, convexiusculis, margine inferiore præcipue insigniter crispatis vel undulatis ; inferioribus ligulatis, undulatis. Color flavo-virescens. Stipulce cordatæ, planiusculæ, marginibus lateralibus revolutis. Fructificatio ignota.

The curiously crisped leaves of this species have a very beautiful appearance, and will serve at first sight to distinguish it from $J$. platyphylla, with which it has so many points in common, that, even if possessed of this character alone, constant as it appears to be, I should not venture upon describing it as distinct. A more important mark of difference is observable in the shape of the stipules, which are here cordate; in J. platyphylla ligulate. It is more like the var. $\beta$. of $J$. platyphylla than the common appearance of it.

Fig. 1, plant, nat. size. Fig. 2, leaves and stipules. Fig. 3, portion of a leaf,-magn. 


\section{MUSCI Exot I I.-Menziesiani.}

\section{DICRANUM FLEXIFOLIUM.}

Dicranum caule subnullo, foliis longissime subulatis flexuosis, perichætialibus longe vaginantibus, seta mediocri, capsula oblonga erecta lævi absque struma, operculo conico-acuminato. (TAB. CXLIV.)

Hab. In Capite Bonæ Spei. D. Menzies, 1791.

Radix parva, fibrosa. Caulis subnullus. Folia e lata basi concava, longissime subulata, flexuosa, integerrima, nervo angusto, marginibus inflexis, inferiora breviora. Perichcetialia longe vaginata, ad basin caulis circumvoluta, apice subulata, integerrima, nervo obscuro. Seta vix unciam longa, flavescens. Capsula oblonga erecta intense fusca, lævis. Operculum conicoacuminatum, fuscum. Peristomium et Calyptram nondum vidi.

This comes perhaps nearest in general appearance to $D$. crispum ; but from that and all the other species which have little or no stem it differs in the perichætial leaves, which are remarkably sheathing like $D$. scoparium and its affinities. It is from habit alone I judge it to belong to this genus; for I have seen no peristome, and the operculum is singularly short and obtuse, in this respect approaching that of Didymodon purpureum and some others.

Fig. 1, 1, 1, plants, nat. size. Fig. 2, plant without the capsule. Fig. 3, exterior leaf. Fig. 4, superior ditto. Fig. 5, perichætial leaf. Fig.6, capsule. Fig. 7, operculum.-magn. 


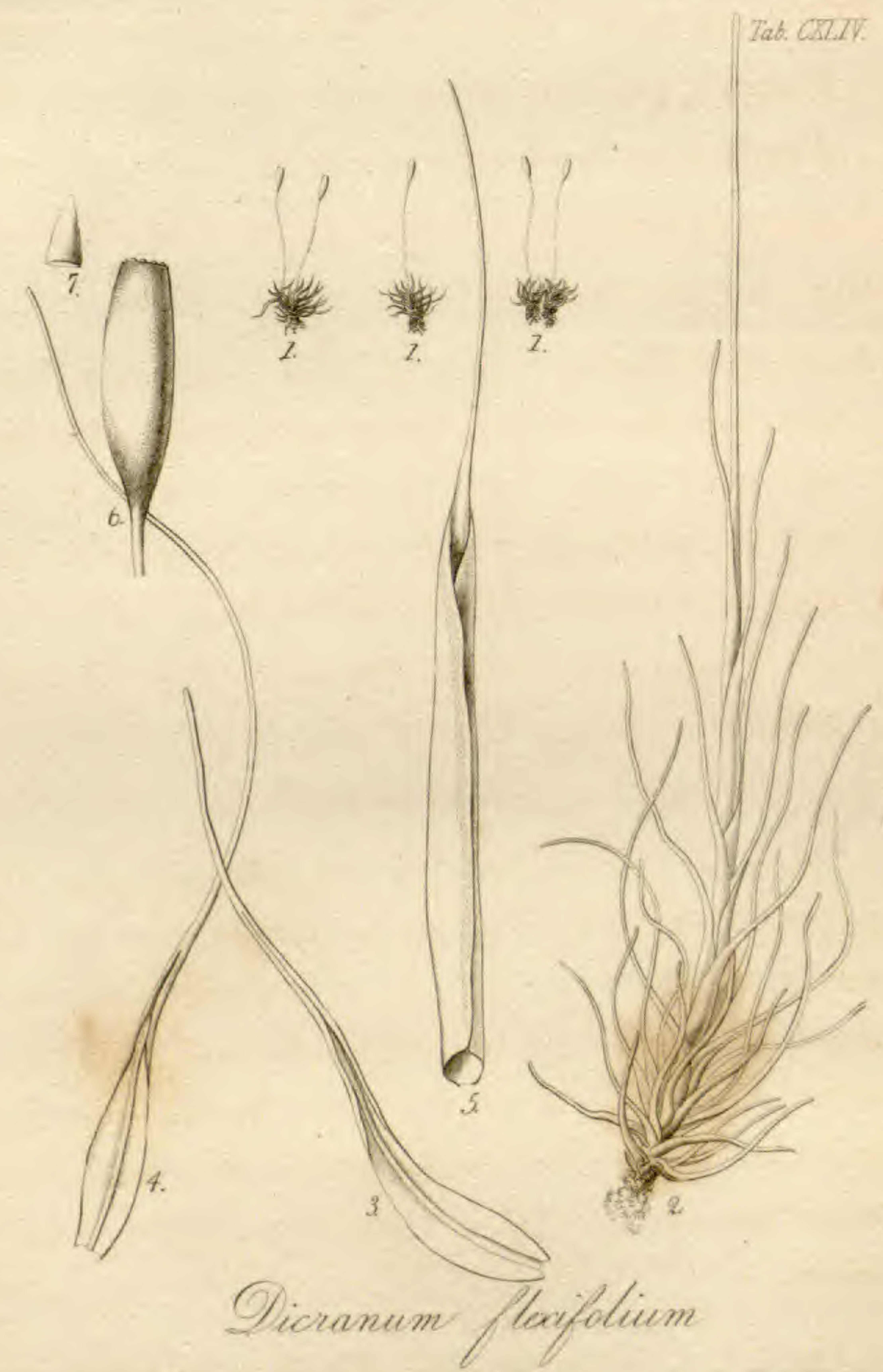



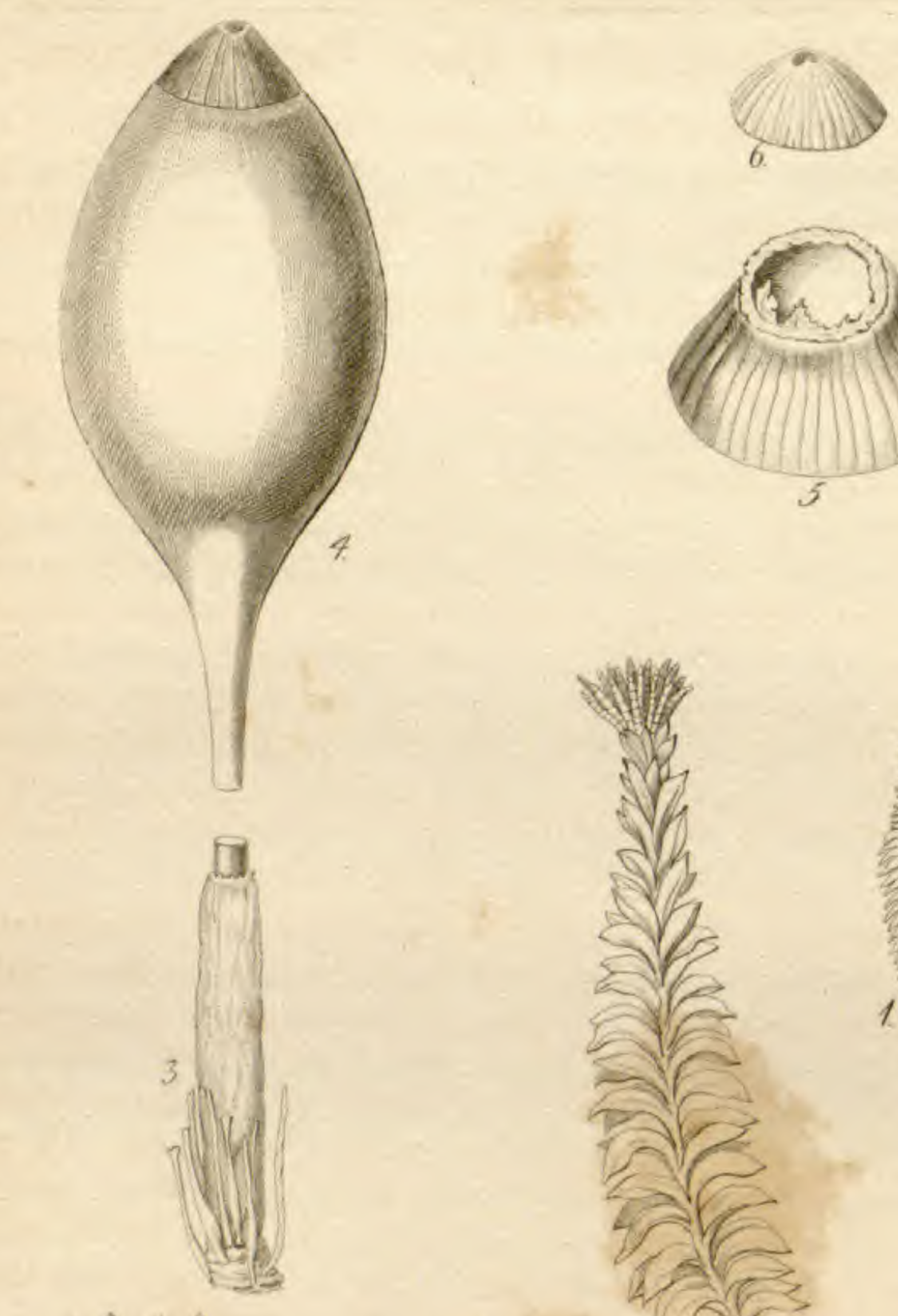

Tab CXLV
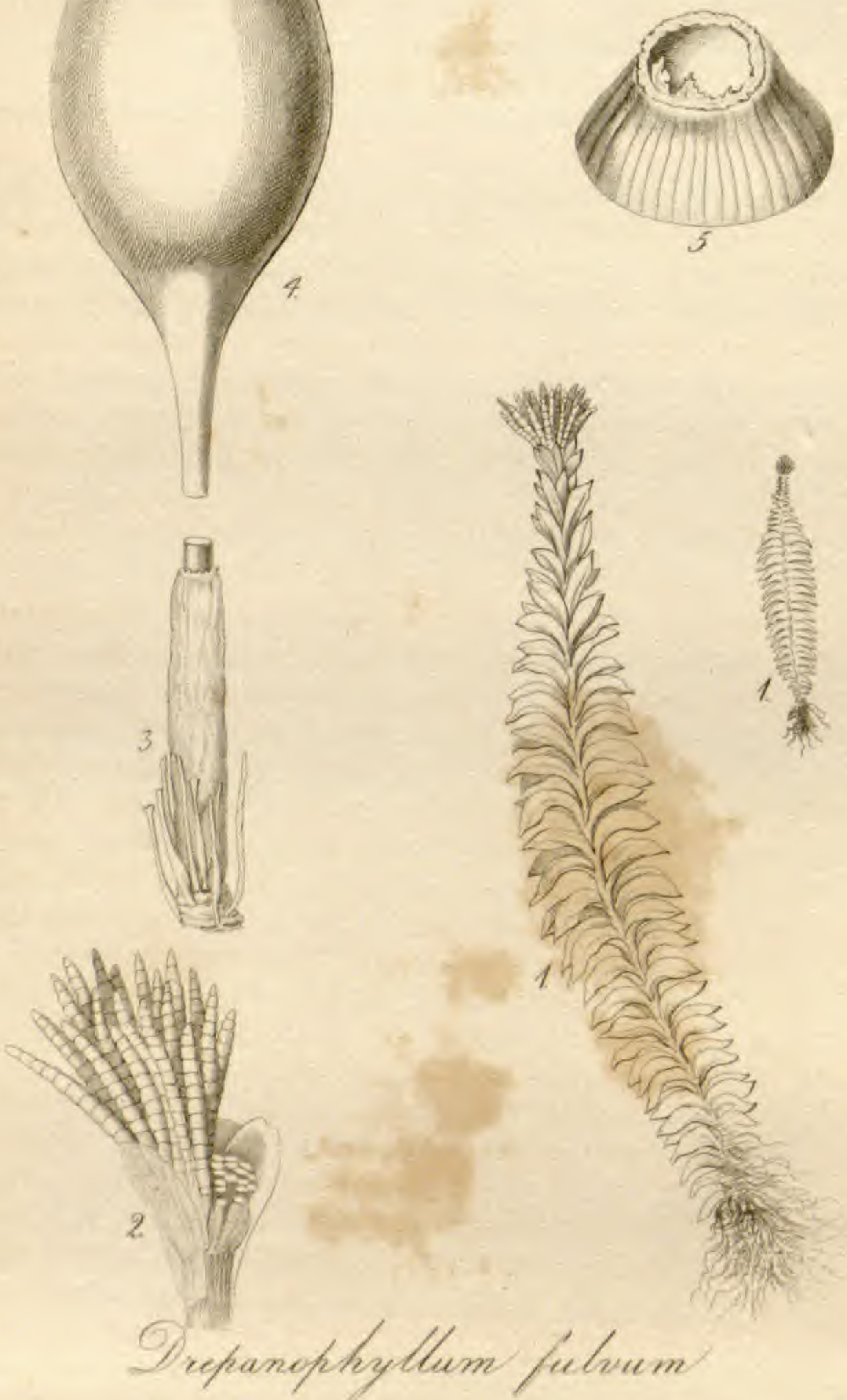


\section{DREPANOPHYLLUM FULVUM.}

('ав. CXLV.)

\section{Dicranum? falcifolium. Hook. Musc. Exot. t. Lxxxir.}

НАB. In sylvis Guyannæ Gallicæ. D. Prof. Richard.

Hujus pulchelli musci sunt individua dimorpha, in iisdem quidem arborum truncis habitantia, diversis vero sedibus : alia (ad nutum Hedwigii) foemellina, alia masculina.

1. Femmllina, vid. TAB. LXXXII, et adde

Capsula matura ovata. Operculum demisse subconoideo-convexum, apice tantisper depressum. Peristomium nudum. Interdum quidem interior aperturæ margo nonnullas contextûs interni, operculo suppositi et ab eo decidente rupti, aliquandiu retinet laciniolas; sed certe desunt et dentes et membranula. 2. Masculina per summitates, propter folia gradatim brevicra minusque recurva sursùm angustatas, mox dignoscuntur. Illa autem superiora folia insertione magis ac magis inter se distant fiuntque obtusiora; et ita ut suprema, erecto-appressa nec in rosulam concinnata, apicem rotundatum habeant et muticum. Ex is solito duo intima, multo breviora, subrotunda, enervia, ex ipso capituli filamentosi ambitu oriuntur basibusque filamentorum apprimuntur tota; et etiam nonnullorum summorum foliorum nervus desideratur.

Absque manifesto caulis summi tumore, hujus apex numerosa protrudit corpuscula filamentiformia, densissime capitata s. fasciculata, supra ambientia folia promisse exerta ; quorum congeries, penicillum amoene purpureum æmulans, oculos Bryophili mox allicit recreatque. Illorum unumquodque est filamentum tenuiter subclavato-fusiforme, rectum, crebro articulatum; articulis 12-16, cylindricis ; summo minimo, subrotundo-convexo ; infimo cæteris multo longiore. Post elapsa illa, omnium persistunt bases, solito in solo articulo infimo consistentes; et tenaciter perennant densatæ in capitulum subconvexum, stipantibus foliis demissius.

Intersita supradictis filamentis (filis succulentis, et paraphysibus Hedwigii) corpuscula, ab eodem pro antheris habita, etiam in vivis plantis, frustra inquisivi. Richard in litt.

Fig. 1, 1, planta rnasculina, nat. magn. et auct. Fig. 2, ejusdem capitulum, filamentorum; quorum dimidia pars censetur exempta, ut, quales persistunt, conspiciantur bases elapsorum. Fig. 3, vaginula; stipantibus nonnullis adductoribus capillisque. Fig. 4, capsula matura, operculo adhuc clausa. Fig.5, cıpsulæ apertæ summa pars. Fig. 6, operculum.

To this accurate description, which, as well as the drawing, were made by Professor Richard from fresh specimens of the plant in its native country, $I$ shall only add an observation made by the learned Professor in his letter; - "la marche actuelle de la Muscologie vous conduira peutêtre à la réunion de cette plante aux espèces de Gymnostomum. Mais je pense qu'elle retiendra le nom générique que je lui ai donné, si on arrive un jour à une meilleure combinaison des signes propres à caractériser les genres de cette famille."

VOL. II. 


\section{CALYMPERES GARDNERI.}

Calymperes caule breviusculo, foliis linearibus marginibus incurvis serratis, calyptra lævi. (ТAв. CXLVI.) НАв. In Nepal, arboribus. Hon. D. Gardner. Radix fibrosa. Caules cæspitosi, breviusculi, plerumque simplices. Folia undique inserta, erecta, vel erecto-patentia, flexuosa, siccitate torta, inferiora breviter, superiora longe linearia, obtusa, canaliculata, margine incurva, læviter incrassata, serrata, obscure viridia, minutissime areolata, basi amplexantia, alba, distincte reticulata, nervo tenui paulo ultra apicem producto instructa. Seta terminalis, foliis superioribus paulo longior, erecta, rufa. Capsula erecta, oblonga, intense rufo-fusca, nitidissima, siccitate vix sulcata. Operculum capsula subæque longa, e basi lata, planiuscula exacte subulata. Calyptra magna, mitræformis, lævis, non torta, capsulam omnino tegens, demum lateraliter fissa, dimidiata. Peristomium membrana flavo-fusca, horizontalis, spongiosa, totum os tegens, medio radiato-striato, atque maturitate in dentibus 16, brevibus, rufis, transversim striatis, basi semper membrana supradicta spongiosa unitis, fisso.

Among the rich cryptogamic collections made by the Hon. Col. Gardner in the interior of Nepal, which have been communicated to me by my most liberal friend Dr. Wallich, no one plant has gratified me so much as the subject of the present plate, not only because it adds a third species to one of the rarest and most curious genera known, but because numerous specimens in various stages of fructification enable me to amend the generic character * as defined by Swartz, its founder, and by Weber and Sehwaegrichen, who all had only observed the peristome in the state of a membrane. Of the two species described and figured by Schwaegrichen, $-C$. lonchophyllum and C. Palisoli, natives of the West Indies and of Africa, and both of which I possess,- the former is most nearly allied to the one at present under consideration, but differs from them both in the very much shorter and broader leaves, whose margins are incurved, in the great length of the operculum, and especially in the smooth, never striated nor twisted calyptra.

Fig. 1, tuft of plants, nat. size. Fig. 2, single plant. Fig. 3, 3, leaves. Fig. 4, portion of ditto. Fig. 5, young female fruit. Fig. 6, young calyptra. Fig. 7, ditto more advanced. Fig. 8, ditto fallen from the capsule. Fig. 9, capsule showing the young peristome. Fig. 10, peristome more advanced. Fig. 11, portion of ditto-magn.

* It may be thus defined.-Perist. simplex, e membrana spongiosa horizontali totum os tegens, demum medio in dent. 16, brevibus fissa. Calyptra magna, mitræformis, capsulam involvens, demum lateraliter fissa. Seta terminalis.-Wbat Schwaegrichen has figured as the probable male flower on his Calymperes Palisoti, is a parasitic Conferva, very similar to what Mr. Lyell finds abnndantly on our British Orthotrichum Lyellii, and to what I also find on C. Gardneri. The real male flowers which I possess on my specimen of $\boldsymbol{C}$. Palisoti are in axillary and terminal buds, and consist of anthers mixed with succulent flaments, 


\section{Tab. CXLVI.}
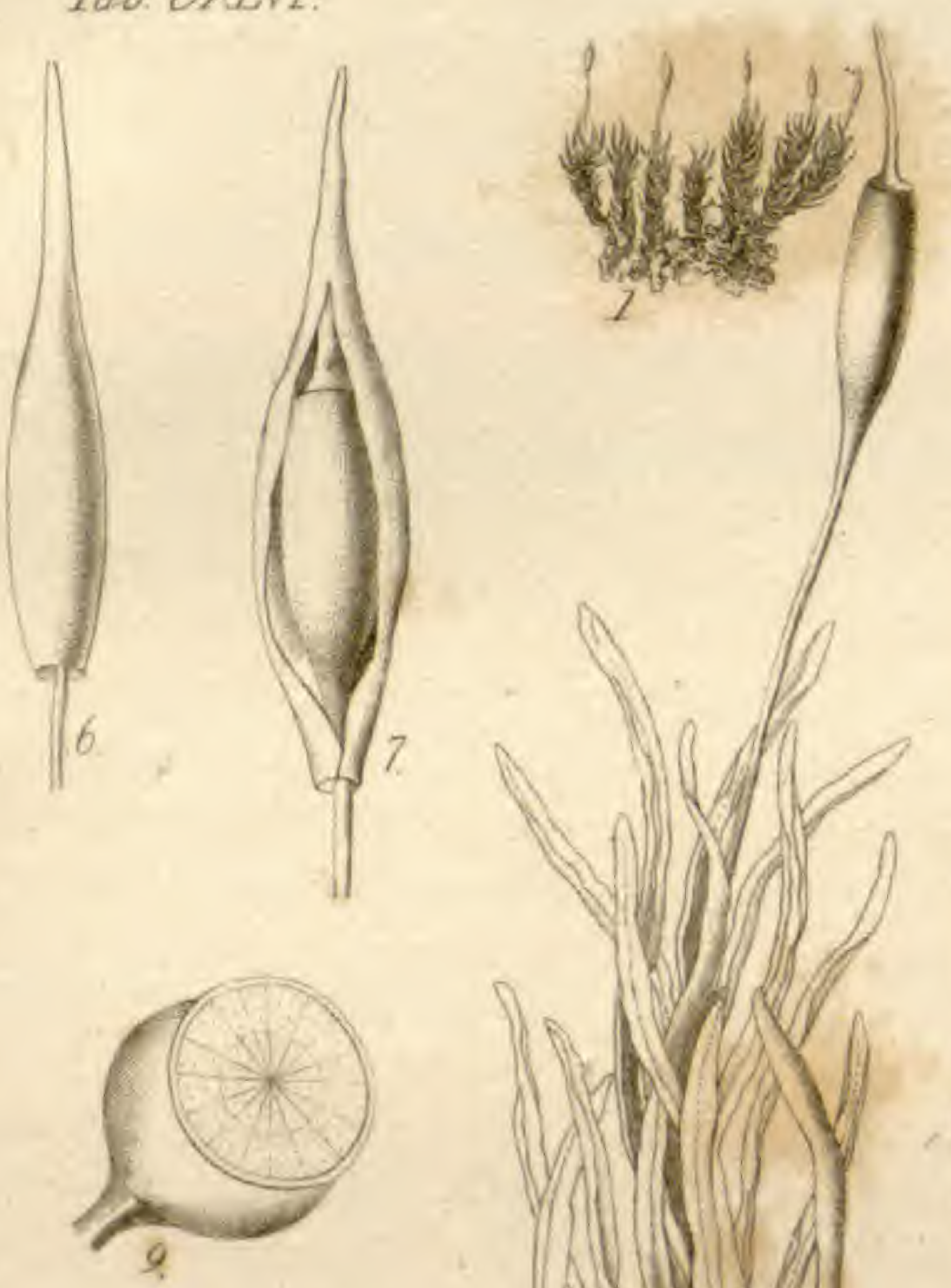

\footnotetext{
(n)
} 
Tab. CXLWI

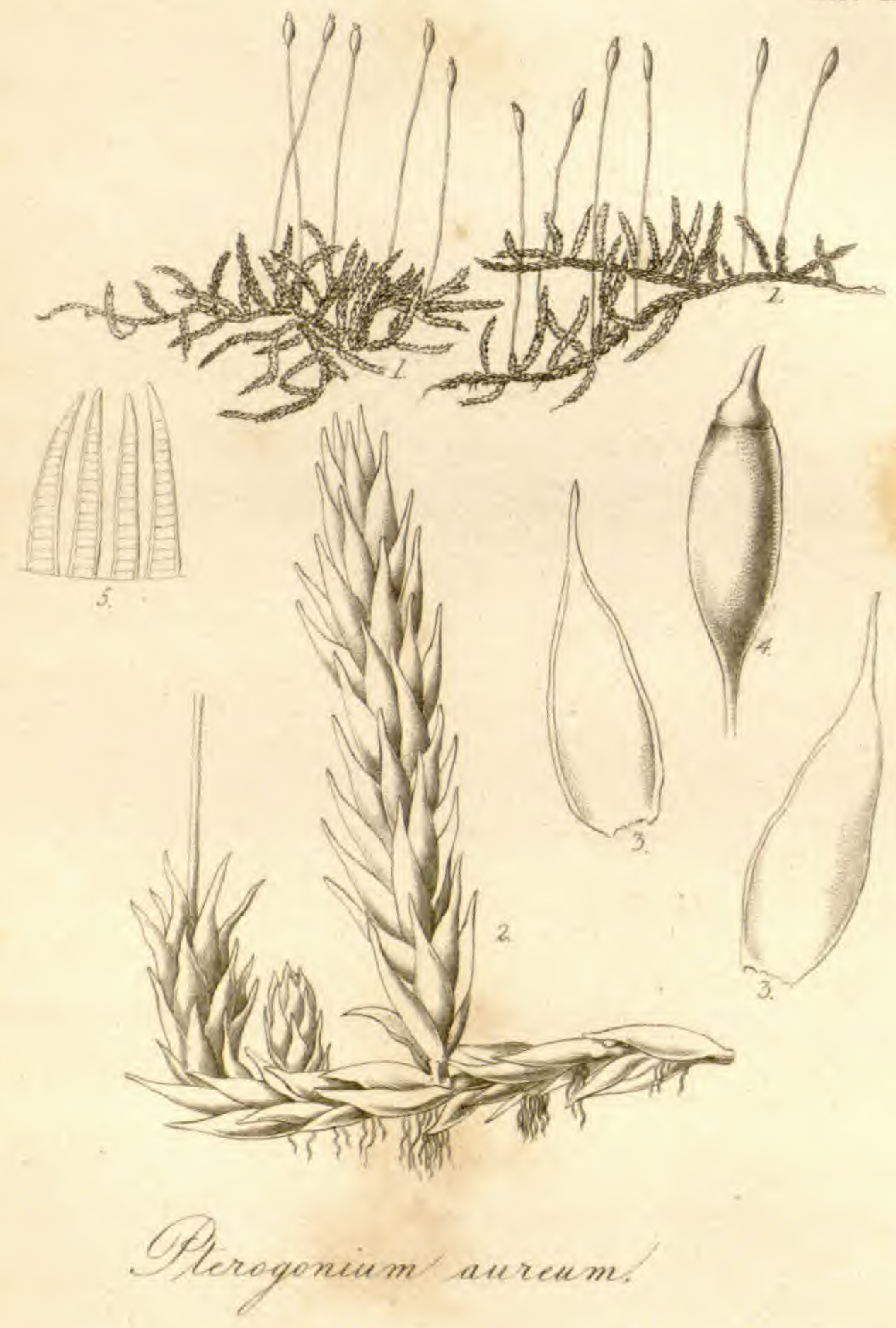




\section{PTEROGONIUM AUREUM.}

Pterogonium caule repente, ramis erectis, foliis undique imbricatis erecto-patentibus ovato-acuminatis concavis, margine recurvis, enervibus, seta longa, capsula oblonga erecta, operculum conico-rostratum.

(TAB.

\section{CXLVII.)}

HAB. In Nepal, arboribus legit Hon. D. Gardner.

Caules repentes, elongati, filiformes, radicantes, ramosi, ramis - erectis, brevibus. Folia undique inserta, aurea, nitida, erectopatentia, ovata, acuminata, concava, margine recurvo, omnino enervia. Seta unciam longa, flava. Capsula rufo-fusca, erecta, oblonga. Operculum fuscum, conico-acuminatum vel rostratum, subobliquum. Peristomium e dentibus 16 , longiusculis rufo-flavis, marginatis, transversim striatis.

This has much affinity in the structure of its parts with $P t$. intricatum ; but the first aspect of the two plants is strikingly different. The present species is much the larger, and remarkable for its almost orange-coloured glossy hue; the leaves too are somewhat different in shape, and always have the margins recurved, which is never the case with Pt. intricatum.

Fig. 1, plants, nat. size. Fig. 2, portion of a plant. Fig. 3,3, leaves. Fig. 4, capsule and operculum. Fig. 5, teeth of the peristome.-magn. 


\section{PTEROGONIUM MYURUM.}

Pterogonium caule (fructifero) suberecto pinnatim ramoso, foliis undique imbricatis erectis ovatis valde con= cavis enervibus integerrimis, seta elongata, capsula oblonga erecta, operculo acuminato. (TAB. CXLVIII.) HAв. In Nepal. Hon. D. Gardner.

Caules steriles, repentes, radicantes, fructiferi erecti vel decumbentes pinnatim ramosi, ramis distantibus patentibus subclavatis, Folia undique inserta, erecta, arcte imbricata, pallide viridia, exacte ovata, valde concava, obtusa cum mucrone minutissimo, integerrima, enervia vel basi solummodo obsoletissime binervibus, Seta longa. Capsula oblonga, rufo-fusca, ore annulato. Operculum conico-acuminatum. Peristomii dentes 16 , rufi, marginati, transversion striati.

This plant has so much the habit of a Hypnum, or rather perhaps that of a Leskea, that it was only after an examination of various capsules that I was able to satisfy myself that it had but a single peristome. The teeth, too, are singularly rigid. Among the Pierogonia I know of none with which it is at all liable to be confounded.

Fig. 1, fertile, and Fig. 2, sterile plants, nat. size. Fig. 3, portion of a fertile plant. Fig. 4, leaf. Fig. 5, capsule.$\operatorname{magn}$. 
Iab. CXLIIII

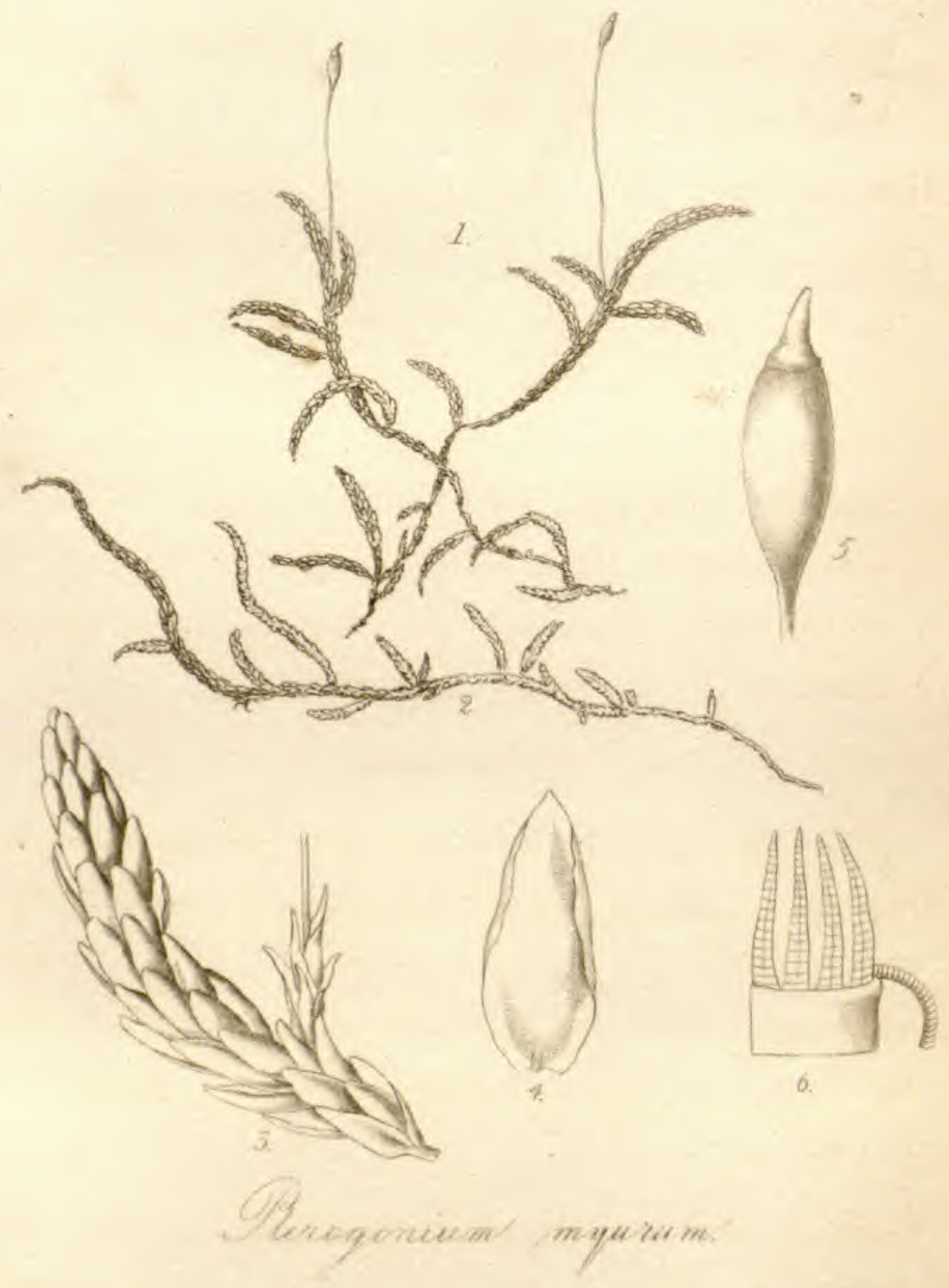




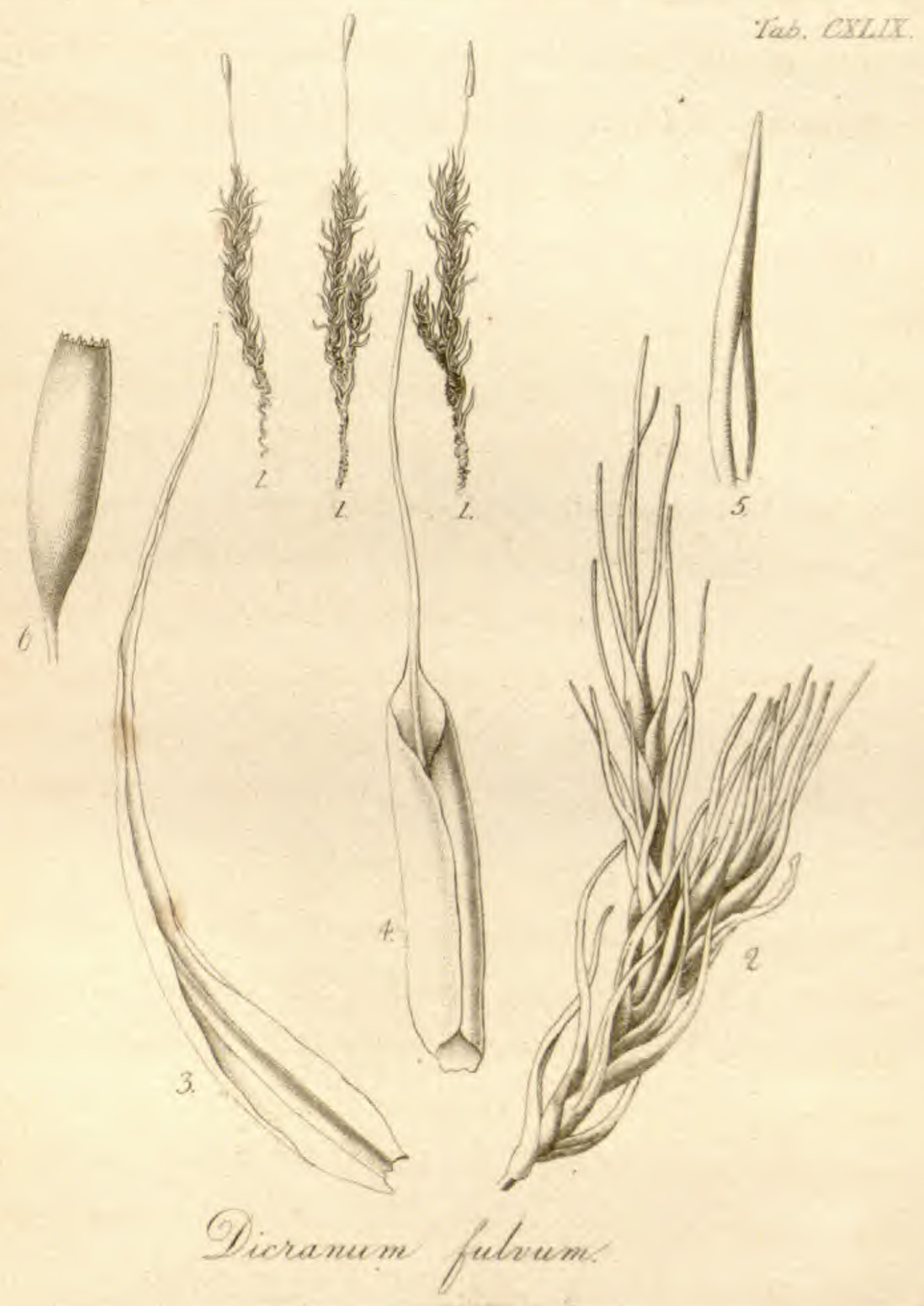




\section{DICRANUM FULVUM.}

Dicranum caule elongato erecto ramoso, foliis undique insertis lanceolato-subulatis integerrimis concavis flexuosis siccitate crispatis, nervo crasso, perichætialibus vaginantibus aristatis, seta breviuscula, capsula oblonga cylindracea erecta. (TAB. CXLIX.)

HaB. In Nova Scotia. D. Menzies, 1785 .

Caules sesquiunciales, erecti, subramosi. Folia flavo-fulva, undique inserta, erecto-patentia flexuosa, siccitate valde crispata, e lata basi lanceolata longe subulata, concava, integerrima, nervo crasso concolore instructa. Perichatialia longe vaginata, nervo in acumen vel potius aristam longam flexuosam excurrente. Sela ob innovationes caulis sæpe infra apicem, breviuscula, erecta, Capsula oblongo-cylindracea, fusca. Calypira dimidiata, Peristomium operculumque desunt.

My specimens of this moss are not so perfect as I could wish. - That it is a Dicranum, however, will scarcely admit of a doubt; and that it is of the same family as D.scoparium, to which species perhaps it approaches nearer than to any other. It is, nevertheless, much smaller, of a remarkably fulvous colour, with leaves very much crisped when dry, and with a strong nerve, which at once distinguishes it from all its affinities.

Fig. 1, plants, nat. size. Fig. 2, portion of a plant with the perichætium. Fig. 3, leaf. Fig.4, leaf of the perichætium. Fig. 5, calyptra. Fig.6, capsule.-magn. 


\section{DIDYMODON SQUARROSUM.}

Didymodon caule elongato flexuoso, ramoso, foliis undique patentibus squarrosis longe lanceolatis flexuosis carinatis serratis, seta elongata, capsula cylindracea, operculo longe subulato. (ТАв. CL.)

HAB. In Nepal. Hon. D. Gardner.

Caules digitales et ultra, cæspites magnos densos efformantes, erecti, flexuosi, dichotome ramosi. Folia undique inserta, patentia vel etiam recurva, et ita squarrosa, flavo-viridia, longe lanceolata, carinata, flexuosa, submarginata, inferne præcipue, superne serrata, nervo ad apicem attingente percursa; substantia tenera, compacta tamen, areolis minutissimis. Perichretialia reliquis similia sed magis elongata et setæ basin amplexantia, erecta. Seta terminalis, uncialis et ultra, flava. Capsula cylindracea flavo-fusca. Calyptra dimidiata. Operculum longe rostratum flavum, basi rufum. Peristomium e dentibus 32 , setaceis, per paria arcte approximatis pallide rufis.

This fine moss has the greatest resemblance in its leaves and fructification to a very rare and minute one of our own country, Didymodon flexifolium. It has a similar perichætium, and the leaves are in like manner flexuose; but then these latter are in our present plant of a long lanceolate figure, gradually tapering to a point, whilst those of D. Alexifolium are ovate and obtuse.

D. squarrosum has certainly more the character of a Trichostomum than of a Didymodon; but to this last genus it assuredly belongs, having a truly dimidiate calyptra.

Fig. 1, plants, nat. size. Fig. 2, portion of a stem with the perichætium. Fig. 3, leaf. Fig. 4, apex of ditto. Fig. 5. calyptra. Fig. 6, capsule. Fig. 7, peristome. Fig. 8, portion of ditto.-magn. 


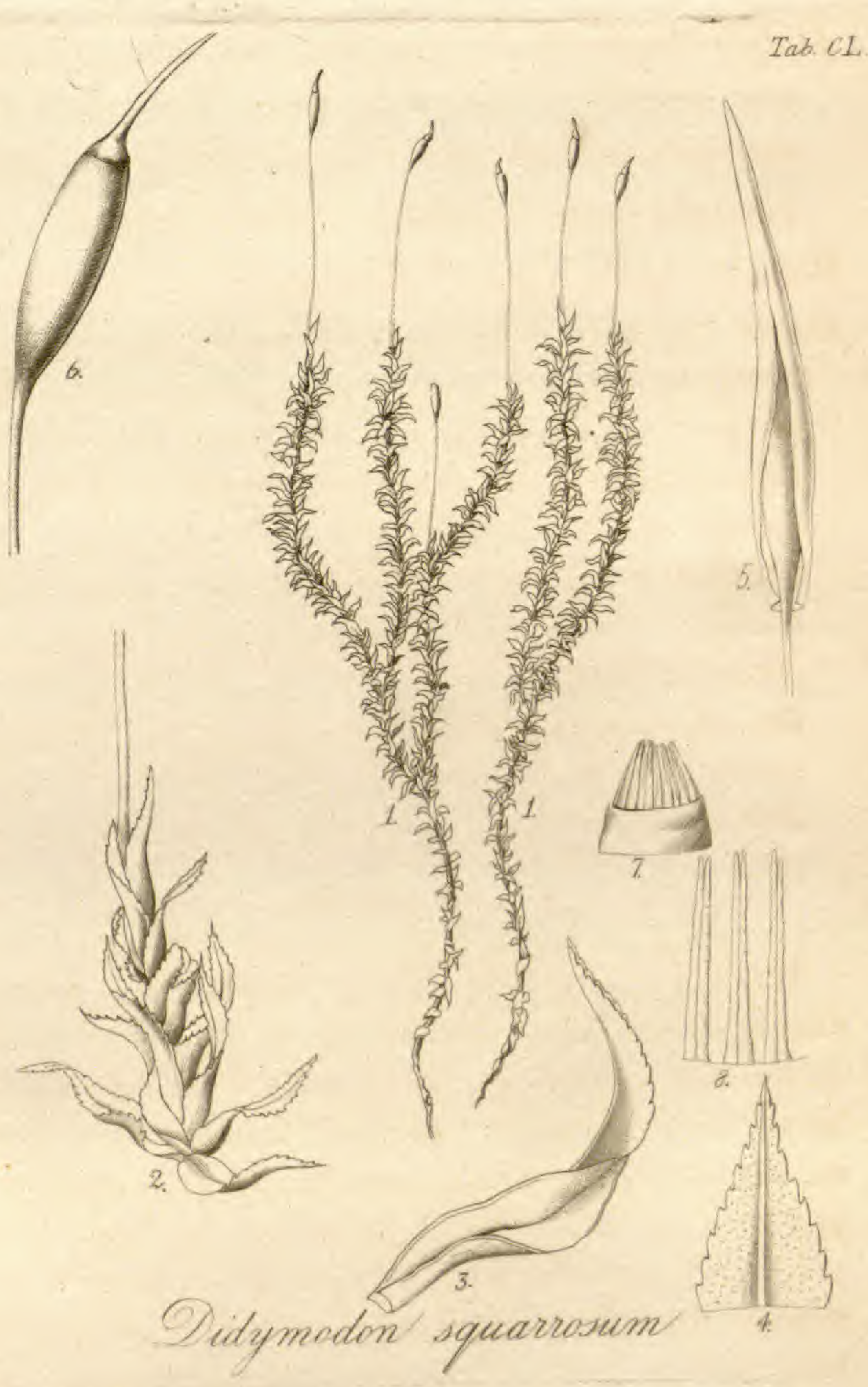




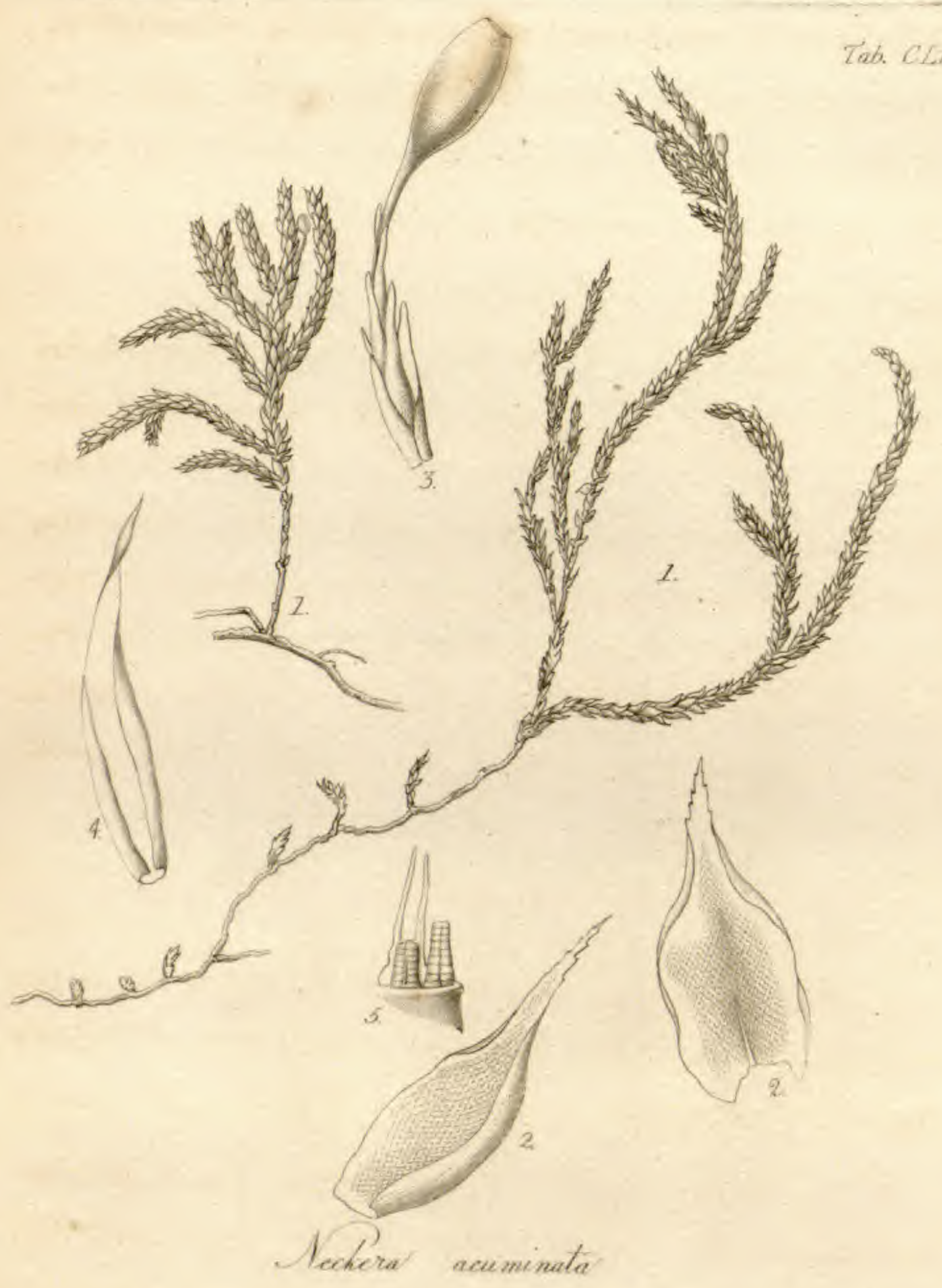




\section{NECKERA ACUMINATA.}

Neckera caule erectiusculo ramoso inferne subsimplice, foliis undique imbricatis erectis late ovatis valde concavis acuminatis subintegerrimis nervo brevi, seta brevi, capsula ovato-oblonga. (TAB. CLI.)

Haв. In Nepal. Hon. D. Gardner.

Radix lignosus, repens. Caules erecti vel decumbentes, rufi, inferne subsimplices, superne vage pinnatim ramosi, ramis crassiusculis. Folia pallide viridia, basi aurantiaca, undique imbricata, erectiuscula, late ovata, valde concava, acuminata, acumine subserrulata, nervo circa medium evanescente instructa; sulstantia tenera, pulcherrime sed tenere reticulata. $P e-$ richœetialia seta dimidio brevia, lanceolata, vaginata, enervia. Seta brevis, curvata. Capsula ovato-oblonga, intense fusca. Peristomium imperfectum, sed videtur ut in Neckera.

I know of no species of Neckera at all resembling this in the form of the leaves, which are not much unlike those of Swartz's Hypnum diaphanum.

Fig. 1, plants, nat. size. Fig. 2, leaves. Fig. 3, perichætium and capsule. Fig. 4, perichætial leaf, Fig. 5, imperfect portion of the peristome.--magn. 
NECKERA CRISPATULA.

Neckera caule longissimo procumbente ramoso, ramis pinnatis, foliis falcato-secundis lanceolatis serratis crispatulis substriatis, nervo ante apicem evanescente, seta brevi, capsula ovata, operculo rostro curvato. (TAB. CLII.)

Hypnum crispatulum. Hooker in Linn. Trans. v. 9. p. 321 . t. 28.

НАв. In Nepal. D. Buchanan et Hon. D. Gardner.

Caules laxe cæspitosi, procumbentes, palmares et ultra, vage ramosi, ramis pinnatis, pinnis plerumque simplicibus. Folia aureo-fusca, undique inserta, falcato-secunda, lanceolata, acuminata, serrata, substriata, superne transversim undulata, siccitate crispatula ; nervo tenui ante apicem evanescente instructa. Perichatialia magis acuminata, nervo obscuro. Seta brevis, curvata. Capsula late ovata, fusca, ore parvo. Operculum rostratum, curvatum. Peristomii dentes ext. 16, valde attenuati flavo-ruf, transversim striati, int. his alternantes, filiformes albi articulati, articulis sæpissime perforatis.

From specimens, very indifferent and without fructification, 1 had originally described this moss in the 9th volume of the Linnean Transactions; but as I now am in possession of very noble ones, I am able by means of them clearly to ascertain the genus to be that of Neckera, although the habit of the plant much resembles that of those Hypna which have falcato-secund leaves. No Neckera having been hitherto known to have leaves of this sort, that circumstance alone would distinguish this species from all others, did not their shape, nerve and serratures also furnish abundant characters.

Fig. 1, plants, nat. size. Fig. 2, leaf. Fig. 3, perichætium and capsule. Fig. 4, leaf of perichætium. Fig. 5, peristome. Fig. 6, portion of ditto. Fig. 7, outer and inner tooth of ditto.magn. 


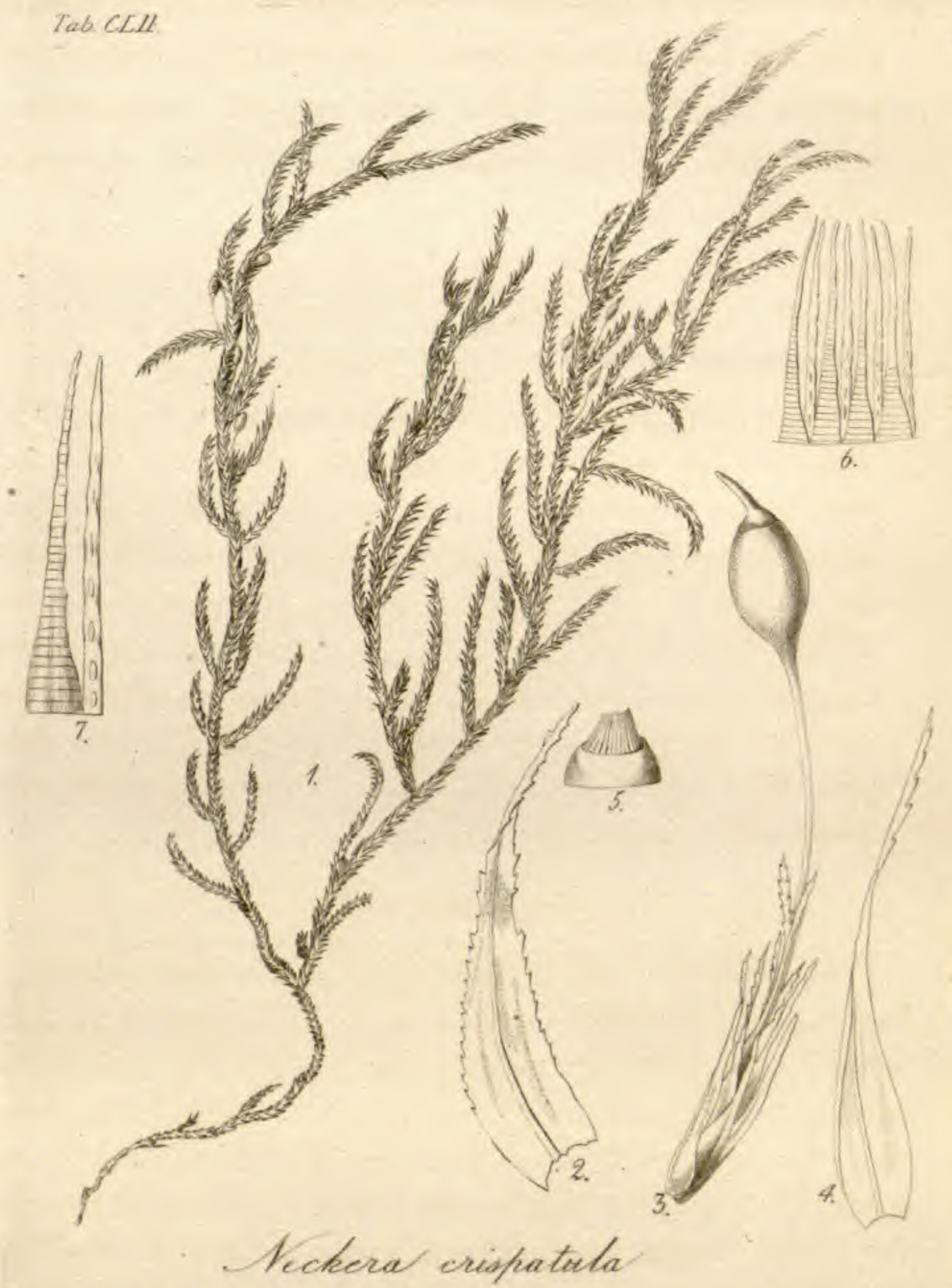


Tad dofi.

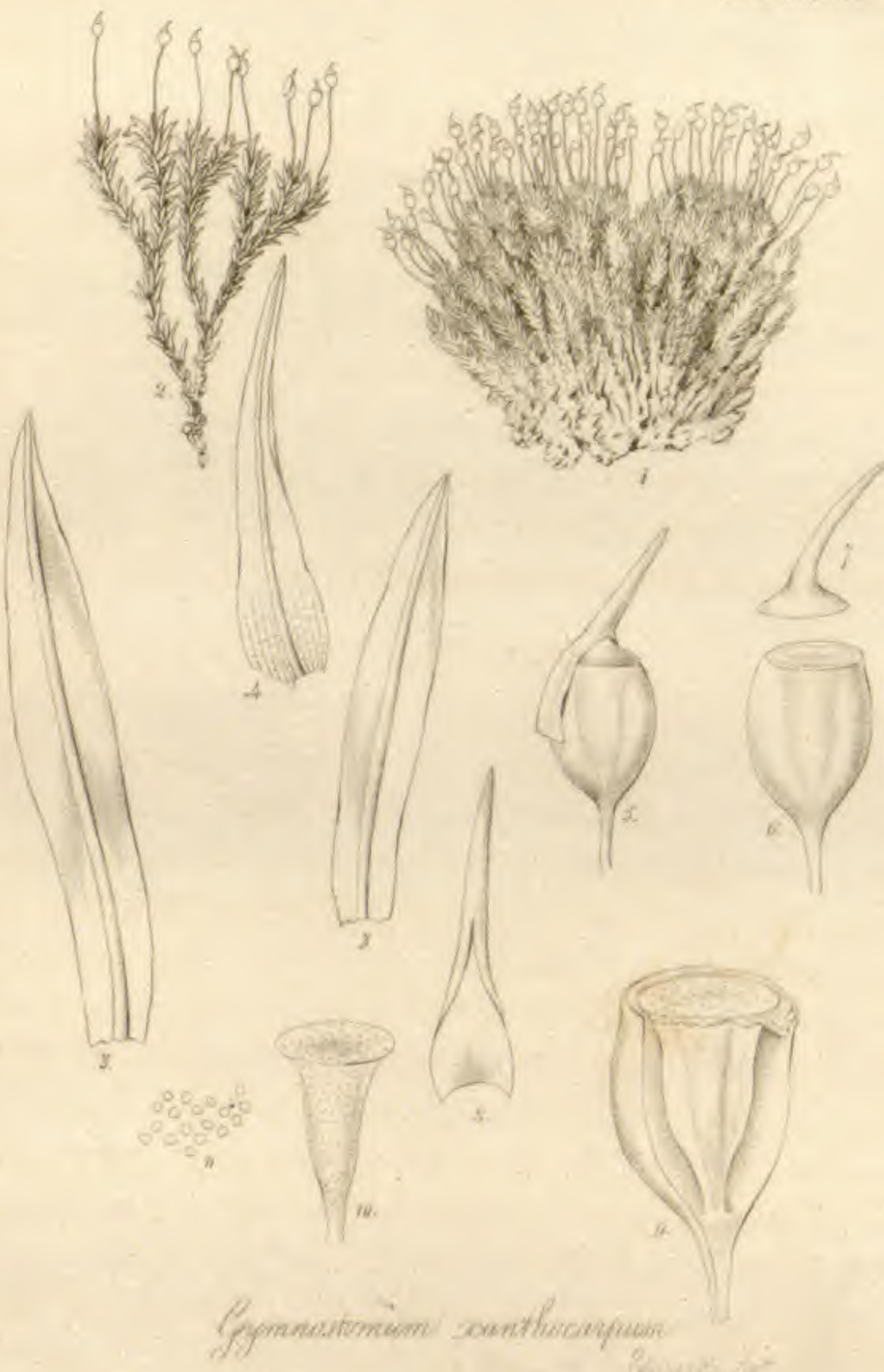




\section{Musci Exotici.-Gardneriani.}

\section{GYMNOSTOMUM XANTHOCARPUM.}

Gymnostomum caule densissime cæspitoso fastigiatim ramoso, foliis patentibus lineari-lanceolatis, seta longiuscula, capsula ovato-sphærica, operculo longirostro curvato. (TAB. CLIII.)

НАв. In Nepal. Hon. D. Gardner.

Caules cæspites densos efformantes, sesquiunciales, erecti, ramosi, ramis fastigiatis. Folia lurido-viridia, patentia, lineari-lanceolata, planiuscula, mollia, integerrima, nervo ad apicem attingente percursa. Perichatialia subulato-lanceolata. Seta semiunciam longa, erecta, flava. Capsula pulcherrime flava, lævis, ovato-sphærica, ore truncato, membrana horizontali columellæ affixa, clausa. Calyptra subulata, dimidiata. Operculum e basi plano-convexa, subulatum, capsula subæque longum, rostro curvato. Semina minutissima, hyalina.

It has been already remarked in the Musc. Brit. (p. 9.) that some species of Gymnostomum are furnished with a horizontal membrane, and that in one species, G. Griffithianum, it is not unfrequently entire. Such too is remarkably the case in the present plant, where it is most clearly the flattened and dilated summit of the columella. (Vid.f. 10.) Another peculiarity in this moss is the smallness of the seminal bag, which does not occupy one half of the cavity of the capsule. It is united above to the lower edge of the horizontal or dilated summit of the columella, and there bursts, when the seeds are discharged. So delicate is the structure of the capsule, that the seminal bag may be clearly seen through it when held between the eye and the light.

As a species, the G. xanthocarpum will rank near to G.curvirostrum, differing, besides the circumstances above noticed, in the form of the leaves.

Fig. 1, tuft of plants; and Fig. 2, single plant, nat. size. Fig. 3, 3, leaves. Fig. 4, perichætial leaf. Fig.5, capsule with its operculum and calyptra. Fig. 6, capsule. Fig. 7, operculum. Fig. 8, calyptra. Fig. 9, capsule cut open to show the seminal bag and the columella terminating in a horizontal membrane. Fig. 10, columella. Fig. 11, seeds.-magn.

VOL. II. 


\section{GYMNOSTOMUM INVOLUTUM.}

Gymnostomum caule elongato subramoso, foliis ovatolanceolatis margine insigniter involutis, nervo ad api* cem attingente, seta elongata, capsula anguste cylindracea, ore annulato, operculo subulato. (TAB.CLIV.) НАв. In Nepal. Hon. D. Gardner.

Caules laxe cæspitosi, vix unciam longi, simplices vel dichotome divisi. Folia intense-viridia, sublaxe undique disposita, erectopatentia, siccitate crispa, ovato-lanceolata, subcarinata, margine insigniter involuta, integerrima, nervo valido concolore ad apicem attingente sed non excurrente instructa. Perichoetialia reliquis similia. Seta caule paulo longior, erecta, fiava. Capsula elongato-cylindracea, erecta. Os annulo elastico horizontali, demum erecto et dissiliente, præditum. Calypira dimidiata, anguste subulata. Operculum subulatum, capsula triplo brevius.

This has much the habit of a Tortula ; but the capsule is altogether destitute of a peristome, though furnished with an annulus exactly as in Gymnosiomum julaceum of this work. (ТАв. XLII.)* On removing the operculum, a portion of the columella, as it appears to be, always adheres to the inside of it, as may be seen at fig. 9 .

Fig. 1, plants, nat. size. Fig. 2, single plant. Fig. 3, leaf in its natural state. Fig. 4, leaf with the margin spread open to show its figure. Fig. 5, capsule with its calyptra. Fig.6, capsule destitute of a calyptra. Fig. 7, calyptra. Fig. 8, operculum. Fig. 9, section of the base of the operculum. Fig. 10, mouth of the capsule, with the annulus as it appears as soon as the operculum is removed. Fig. 11, mouth of the capsule with the annulus erect and breaking away by its elastic power.magn.

"Where, in the specific character, instead of "folite convolutis" read "perichatialibus convolutis." 


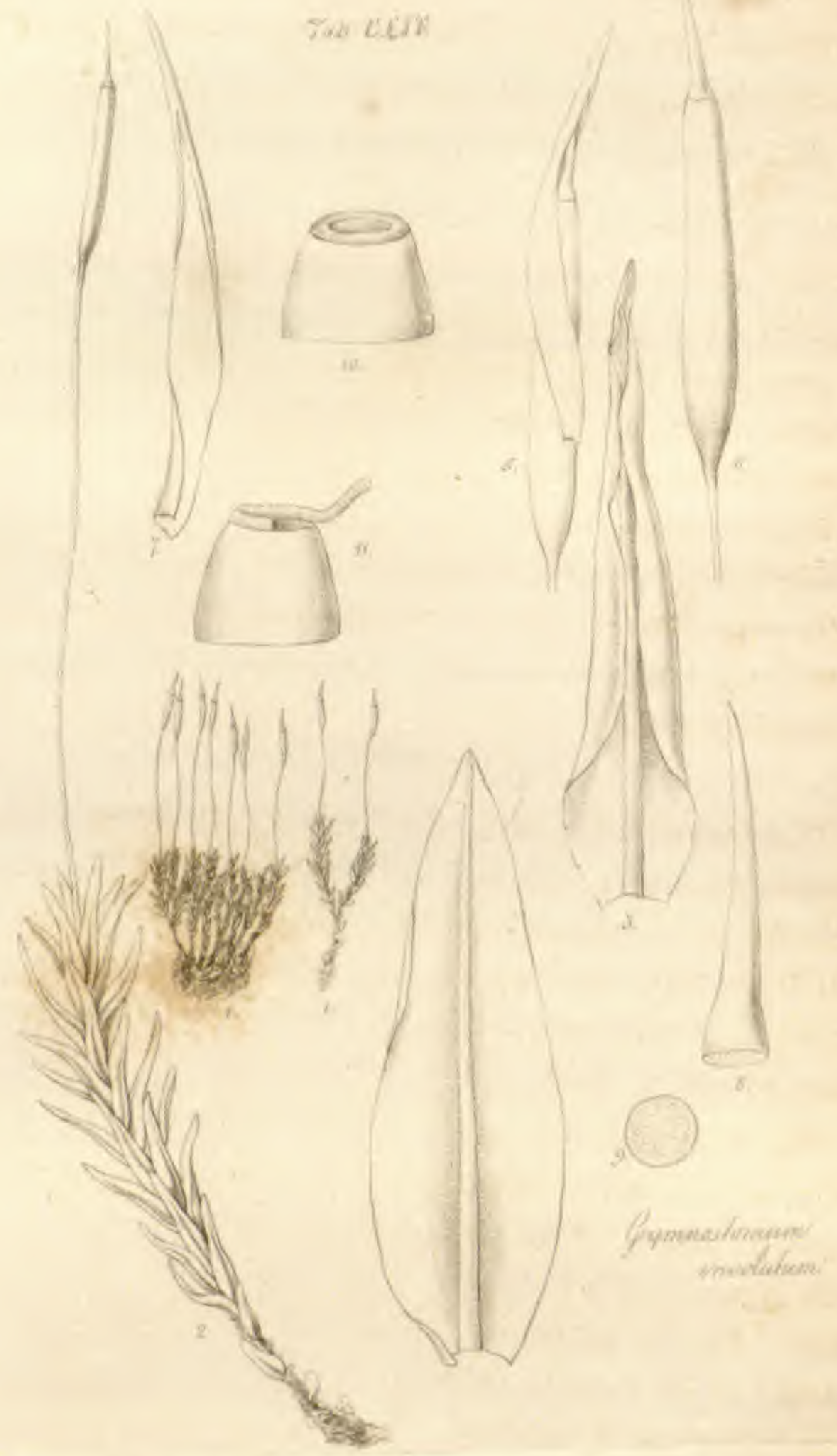


Tab CEV.

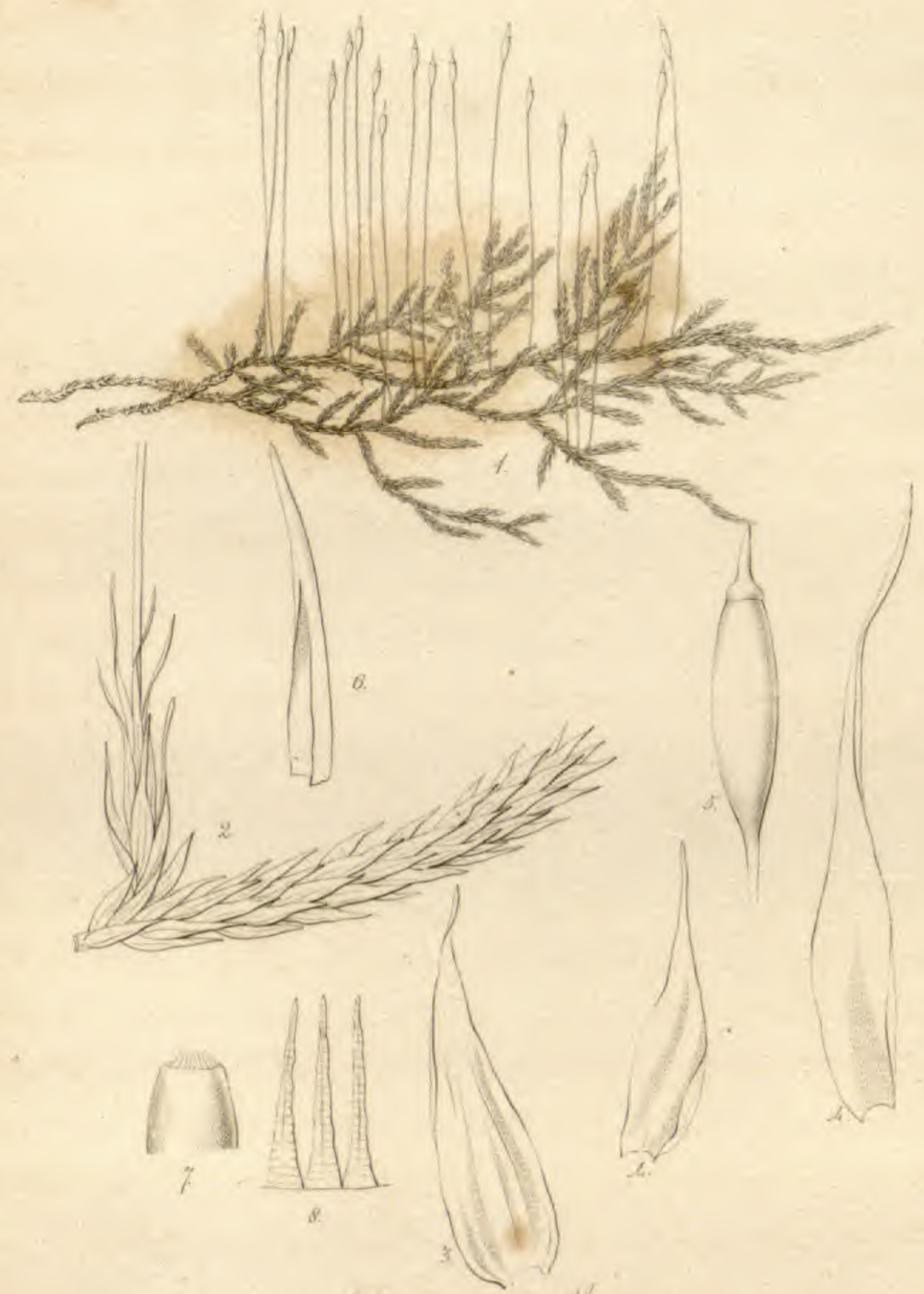

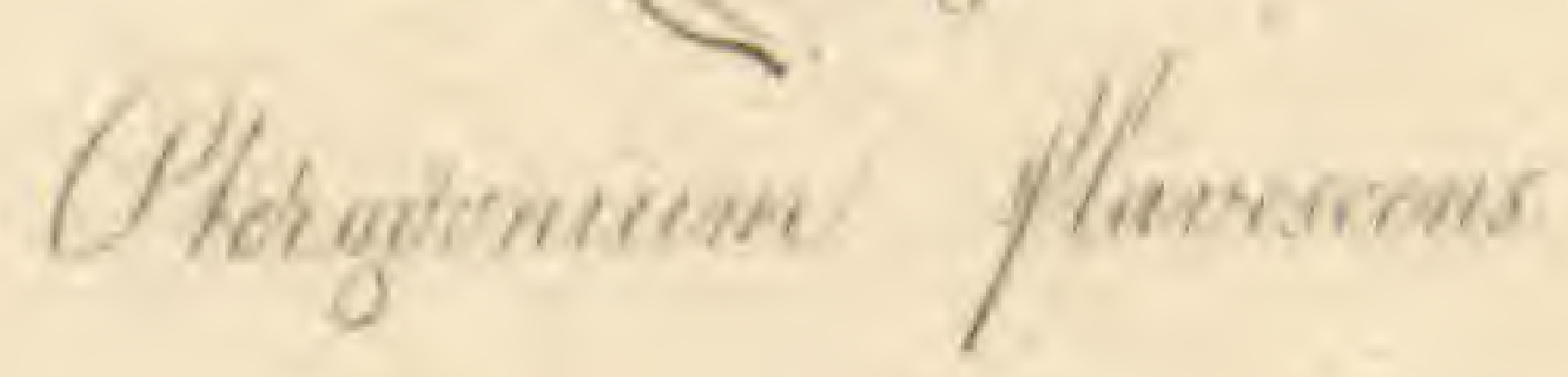




\section{PTEROGONIUM FLAVESCENS.}

Pterogonium caule repente, ramis pinnatis compressis, foliis undique imbricatis erectis lanceolato-acuminatis planiusculis striatis enervibus, seta longa, capsula cylindracea, operculo rostrato. (TAB. CLV.)

Haв. In Nepal. Hon. D. Gardner.

Caules repentes, vage ramosi, ramis pinnatis compressis. Folia flavo-viridia, mollia, erecta vel paululum patentia, lanceolata, acuminata, planiuscula, striata, integerrima, omnino enervia. Perichetialia magis attenuata, striis nullis. Seta subbiuncialis, erecta, flava. Capsula cylindracea, pallide fusca. Operculum e basi convexa, rostratum, rectum. Calyptra dimidiata. Peristomium minutum, e dentibus 16 , subulatis, transversim striatis, sordide rufis, linea media longitudinali notatis.

At first sight this certainly comes very near to Pt. aureum, figured at Tав. CXLVII, of this work. Here, however, independent of the very different colour and want of gloss, the shape and texture of the leaves will be found to be unlike; the branches are here compressed, there cylindrical. The capsules in $\mathrm{Pl}$. $\mathrm{fa}$ vescens are cylindrical, in Pt. aureum oblong. The peristome is different also, and the present is much the larger plant.

Fig. 1, plants, nat. size. Fig. 2, portion of a stem with the perichætium. Fig. 3, leaf. Fig. 4, perichætial leaves. Fig. 5, capsule. Fig. 6, calyptra. Fig. 7, mouth of the capsule with its peristome. Fig. 8, teeth of peristome.-magn. 


\section{SCLO'THEIMIA SULCATA.}

Sclotheimia caule repente, ramis erectis brevibus, foliis lineari-lanceolatis acuminatis undulatis (siccitate crispis), seta longa, capsula ovata profunde sulcata. (TAB. CLVI.)

\section{Hab. In Nepal. Hon. D. Gardner.}

Caules repentes, ramosi, ramis numerosis, erectis, crassis, brevibus, subsimplicibus. Folia fusco-viridia, superiora flavescentia, undique imbricata, patentia, lineari-lanceolata, acuminata, carinata, undulata, siccitate crispa, nervo ad apicem attingente percursa. Perichatialia reliquis similia. Seta semiunciam longa, terminalis, flavescens. Capsula ovata, erecta, intense fusca, profunde sulcata. Operculum hemisphæricum, longe rostratum, rectum, basi intus substantia pulposa columellæ portione farctum. Calyptra campanulata, glabra, fusco-lutea, sulcata, basi ad dimidiam partem longitudinis in segmenta numerosa, apice bidentata, fissa. Perislomium duplex; ext. e dentibus 16 linearibus, geminatis, rufo-fuscis, transversim arcte striatis, erectis, demum revolutis; int. membrana reticulata, flava, erecta, margine hic illic irregulariter fissa.

What Mr. Turner has observed of the Europæan Orthotricha, "Nulli musci, quoad characteres genericos, tam abnormiter ludunt, et tam ægre definiuntur*," may with equal propriety be said of their affinities from the tropics. Hitherto I had in vain searched among those which bore the greatest natural affinity with the genus Sclotheimia of Bridel and Schwaegrichen, for a peristome of that structure. In the present instance I have met with it, and such as accords in every essential particular with the figure in the Supplement to Hedwig's Spec. Musc. Yet the plant itself bears such a resemblance to Ortholrichum longifolium, already figured in this work ( $\mathrm{T}_{\mathrm{AB}}$. XLIV.), that I know of scarcely any other character but the peristome, by which it can be essentially distinguished.

Fig. 1, plant, nat. size. Fig. 2, capsule with the operculum and calyptra removed. Fig. 3, mouth of ditto. Fig. 4, capsule with the operculum. Fig. 5 and 6 , leaves. Fig. 7 , calyptra. Fig. 8, upper portion of the columella removed from the operculum. Fig. 9, operculum. Fig. 10, extremity of a leaf.-magn.

* Musc. Hib. Spec. p. 93. 


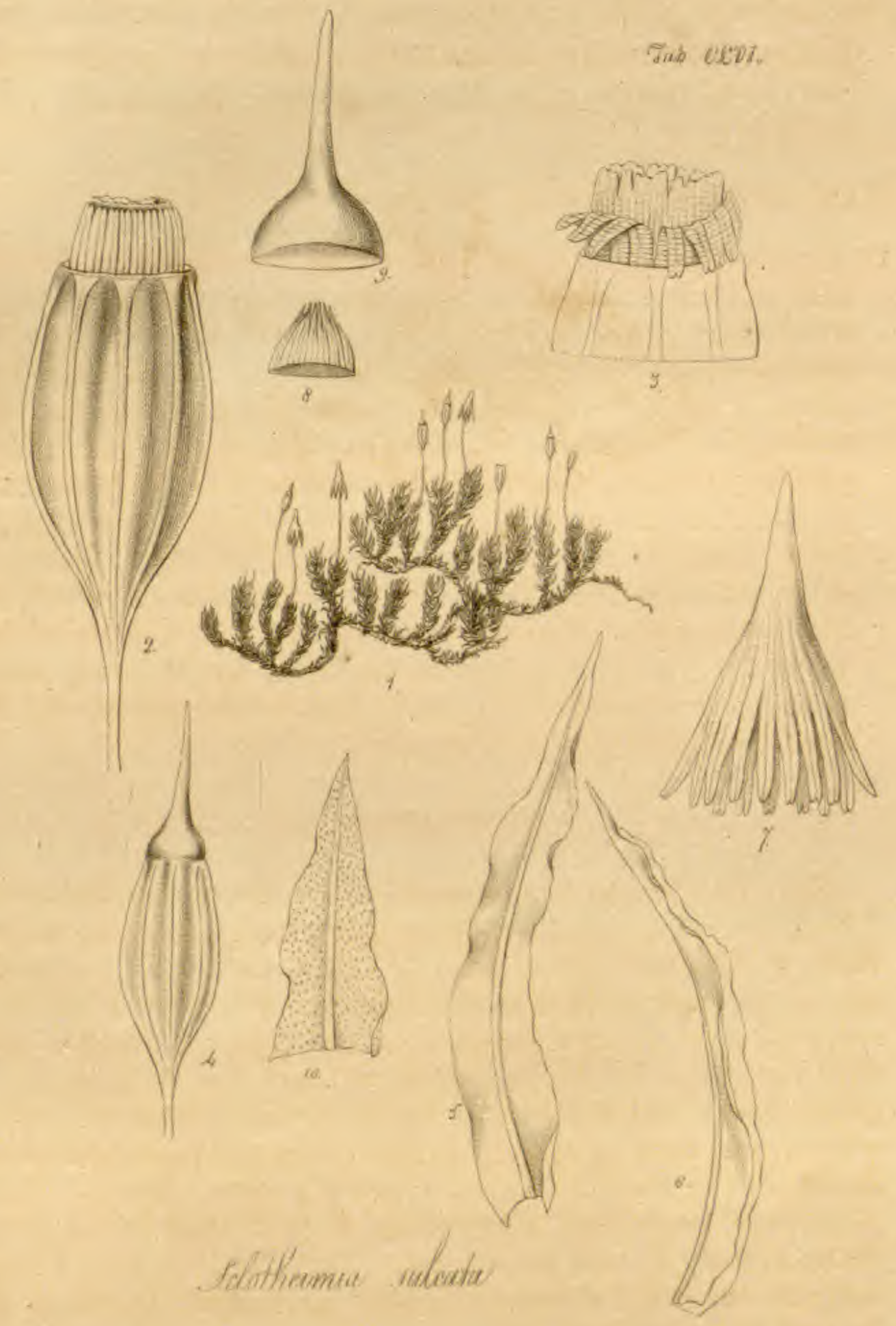




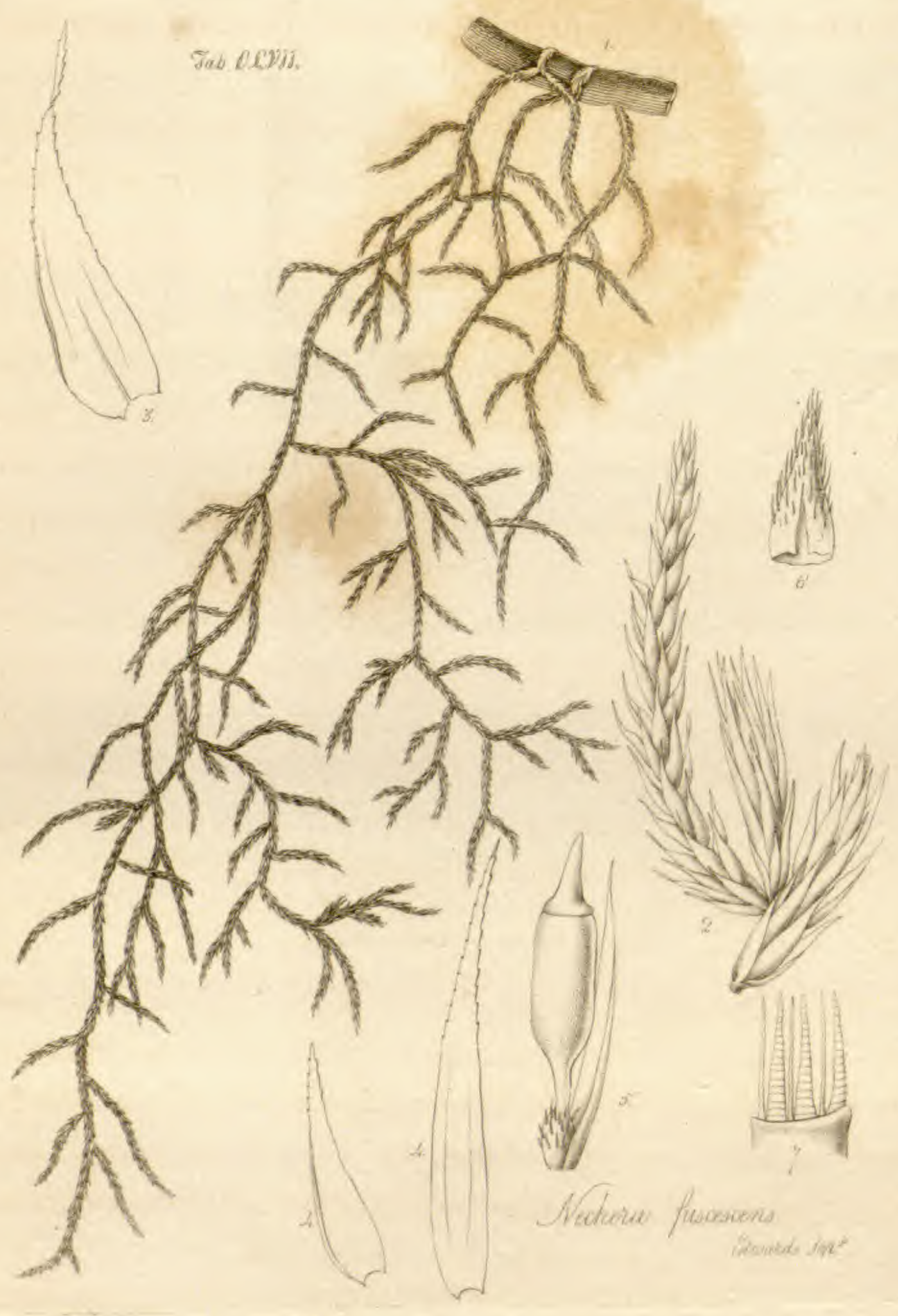




\section{NECKERA FUSCESCENS.}

Neckera caule longissimo filiformi pendulo pinnatim ramoso, foliis lanceolatis acuminatis serrulatis substriatis, nervo ante medium evanescente, seta brevissima, capsula oblonga perichætio immersa, calyptra pilosa. (TAB. CLVII.)

\section{Hав. In Nepal, arboribus. Hon. D. Gardner.}

Caules e ramis arborum pendentes, longissimi, filiformes, flexuosi, molles, pinnatim ramosi, ramis iterumque pinnatis, pinnulis brevibus plerumque simplicibus. Folia fusco-viridia, undique imbricata, erecta, vel erecto-patentia, lanceolata, acuminata, vix concava, substriata, margine ad apicem serrata, nervo brevi ante medium evanescente instructa. Perichcetialin longiora, magis angusta, flavescentia, enervia. Seta perbrevis, recta. Capsula oblonga, fusca. Calyptra brevis, conico-acuminata, pallide fusca, pilosa, hinc longitudinaliter fissa. Operculum conico-subulatum. Peristomii dentes ext. 16, ciliis flavescentibus setaceis his alternantibus.

This plant came intermixed with Neckera filamentosa, and like that grows pendent from the branches and trunks of trees. It ranks naturally with $N$. heteromalla and filiformis of Hedwig, and I should have expected that, like them, it would have had a mitriform calyptra, and thus have come into the genus Dalionia. Such, however, does not appear to be the case.

Fig. 1, plant, nat. size. Fig. 2, portion of a branch with fructification. Fig. 3, leaf. Fig. 4, perichæetial leaves. Fig. 5, capsule. Fig. 6, calyptra. Fig. 7, teeth of peristome.-magn. 


\section{NECKERA FILAMENTOSA.}

Neckera caule longissimo pendulo pinnatim ramoso, foliis squarrosis ovatis concavis undulatis acuminatis, pilo longo flexuoso terminatis, nervo paulo ultra medium evanescente, seta mediocri, capsula cylindracea, calyptra mitriformi (?) pilosa. (TAB. CLVIII.)

HAB. In Nepal, arboribus, legit Hon. D. Gardner.

Caules e ramis longe pendentes, flexuosi, pinnatim divisi, ramis non raro iterum pinnatis, crassis. Folia fuscescentia, juniora flavo-viridia, patentia, squarrosa, ovata, concava, margine integerrima, undulata, apice acuminata, atque pilo valde longo insigniter flexuoso terminata, nervo ultra medium evanescente instructa. Perichatialia reliquis multo minora, ovata, concava, obtusa, emarginata, atque pilo longo subflexuoso terminata, nervo obscuro; intra hæc folia paraphyses numerosæ. Capsula suberecta, oblongo-cylindracea, pallide fusca. Calyptra junior mitriformis, alba, pilis longis obsita. Operculum conico-rostratum, parum obliquum. Peristomii dentes flavescentes, ext. 16 ; int. ciliis totidem his alternantibus.

This fine Moss is very distinct in habit from any with which I am acquainted, except indeed some sterile plants given to Dr. Taylor and myself by Mr. Dickson, without a habitat, which are called by him N. tumida, and which, as far as can be discovered in so imperfect a state, differ only in having the leayes obtuse instead of the cirrhose extremities observable on our present plant.

Fig. 1, plant, nat. size. Fig. 2, leaf. Fig. 3, perichætium. Fig. 4, leaf of ditto. Fig. 5, capsule. Fig.6, calyptra. Fig. 7, teeth of the peristome, - magn. 


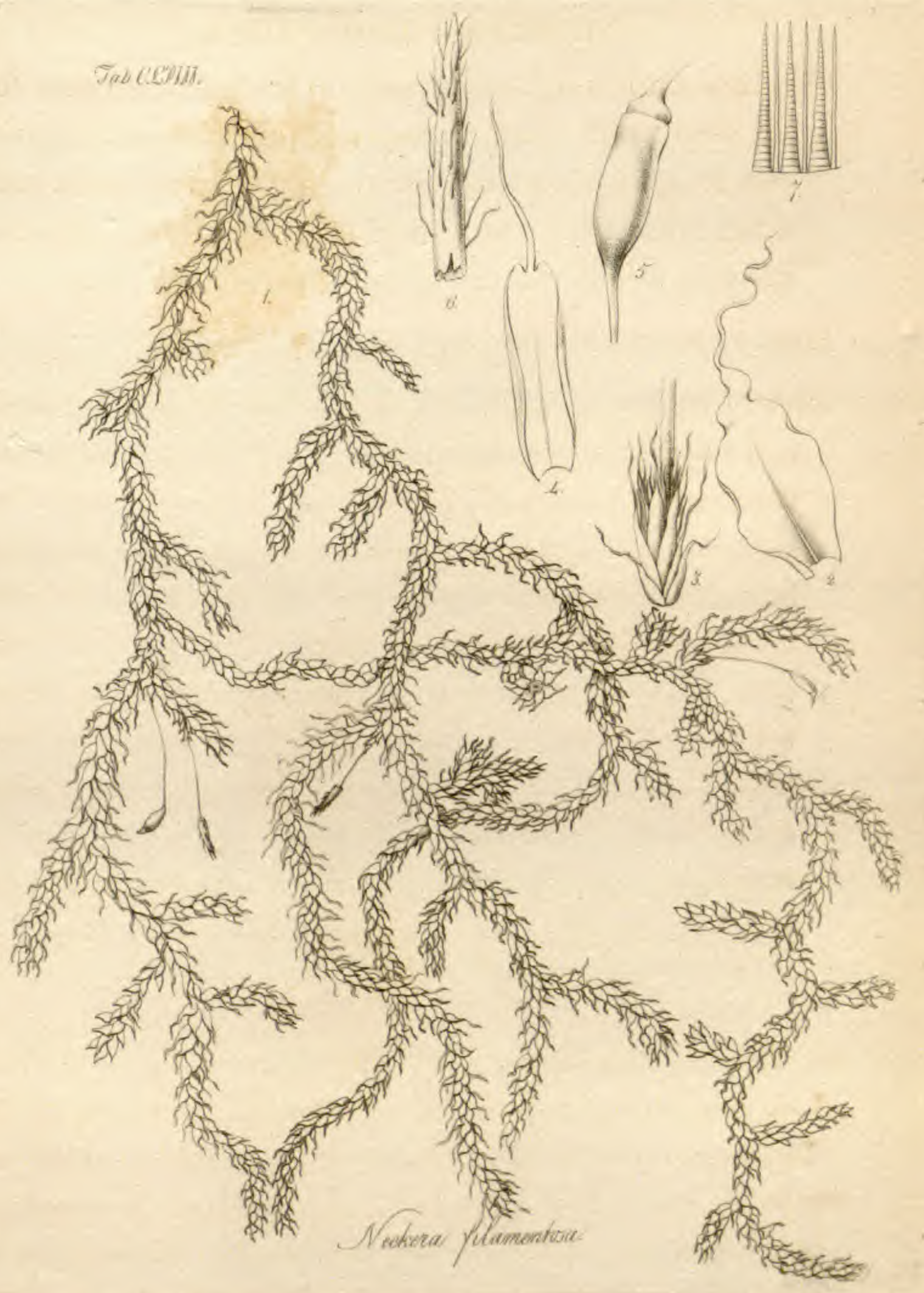




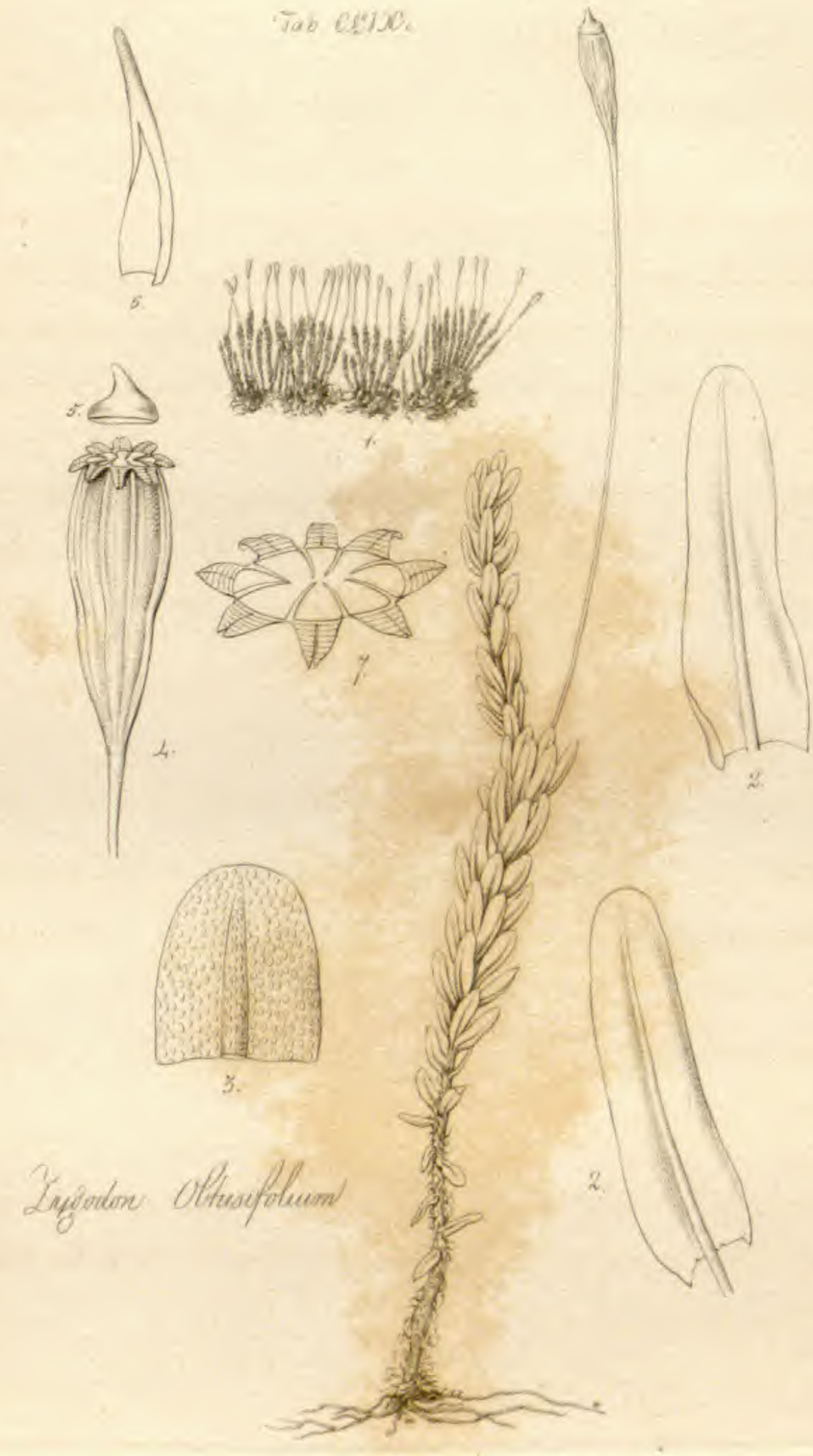




\section{ZYGODON OBTUSIFOLIUM.}

\section{Zygodon foliis obtusis. (TAB. CLIX.)}

НАв. In Nepal. Hon. D. Gardner.

Caules dense cæspitosi, erecti, simplices vel ad apicem innovationibus divisi. Folia sublaxe imbricata, erecto-patentia, rufofuscescentia, lingulata, obtusissima, minute punctata, margine omnino integerrima, nervo satis valido, fusco, paulo infra apicem evanescente, instructa. Perichcetialia reliquorum similia, Seta elongata, gracilis, flavescens. Capsula elongato-pyriformis, intense fusco-rufescens, profunde sulcata. Calyptra dimidiata, glabra. Operculum conicum, subacuminatum, vertice obliquo. Peristomium duplex, pallidum; ext. dentibus 16 per paria approximatis, transversim striatis; int. ciliis 8 horizontalibus setaceis, his alternantibus.

If I may judge from the number of specimens of this interesting plant sent me by my liberal correspondent, it is of not uncommon occurrence in Nepal. The colour is a vinous red approaching to brown, in which it differs from our $Z$. conoideum, though not so essentially as in the very obtuse leaves and longer and narrower capsules.

Fig. 1, tuft of plants, nat. size. Fig. 2, leaves. Fig. 3, apex of leaf. Fig. 4, capsule. Fig. 5, operculum. Fig. 6, calyptra. Fig. 7, peristome.-magn. 


\section{FABRONIA AUSTRALIS.}

Fabronia caule repente ramoso, foliis erectis lanceolatis longe acuminatis reticulatis subserratis, nervo brevi, capsula elliptica, operculo planiusculo. (ТАв. CLX.) Fabroniæ spec. Menz. MSS.

HAB. In sinu King George dicto, in Nova Hollandia. D. Menzies, 1791.

Planta minutissima oculo nudo confervæ simulans. Caules cæspitosi, repentes, vage ramosi. Folia luteo-viridia, erecta, appressa, lanceolata, longe acuminata, parum concava, areolis oblongis angustis reticulata, margine subserrata, nervo obscuro ante medium evanescente instructa. Perichcetialia breviora, magis concava. Selae vix duas lineas longæ, erectæ, curvatæ, pallide fuscescentes, incrassatæ. Capsula erecta, exacte elliptica, fusca, senectute hyalina, ore paululum contracto. Calyptra dimidiata. Operculum planum, centro umbonatum. $P_{e}$ ristomium 8-dentatum, dentibus obtusis, transversim striatis, horizontalibus, incurvatis, rufo-fuscis, singulo linea media longitudinali notato.

So nearly does the present species approach to the $F$. polycarpa ( $\mathrm{T}_{\mathrm{AB}} . \mathrm{III}$.), that I for some time hesitated whether or not it should be considered as a variety of it. Their size is nearly the same, and they may be numbered among the minutest of the mosses. In the $F$.australis, however, the leaves are erect and appressed, not in the least patent, as in the $F$. polycarpa, of a narrower figure, much more acuminated, and subserrated, with narrower reticulations. The capsule is elliptical, not at all turbinate, and the operculum is almost flat.

Mr. Menzies judged very rightly in calling this a Fabronia in his Herlarium ; it having precisely the habit of those Europæan ones figured by Schwaegrichen. Neither in this nor in F. polycarpa have we seen the 8 teeth split down the middle; but there is a strong line, which thus makes in reality 16 teeth united in pairs, or 8 double ones. Each of them again has a fainter line down the centre.

Fig. 1, tuft of plants, nat. size. Fig. 2, single plants. Fig.3, leaf. Fig. 4, perichætial leaf. Fig. 5, capsule. Fig. 6, operculum. Fig. 7, calyptra. Fig. 8, peristome, Fig. 9, teeth of ditto.magn. 


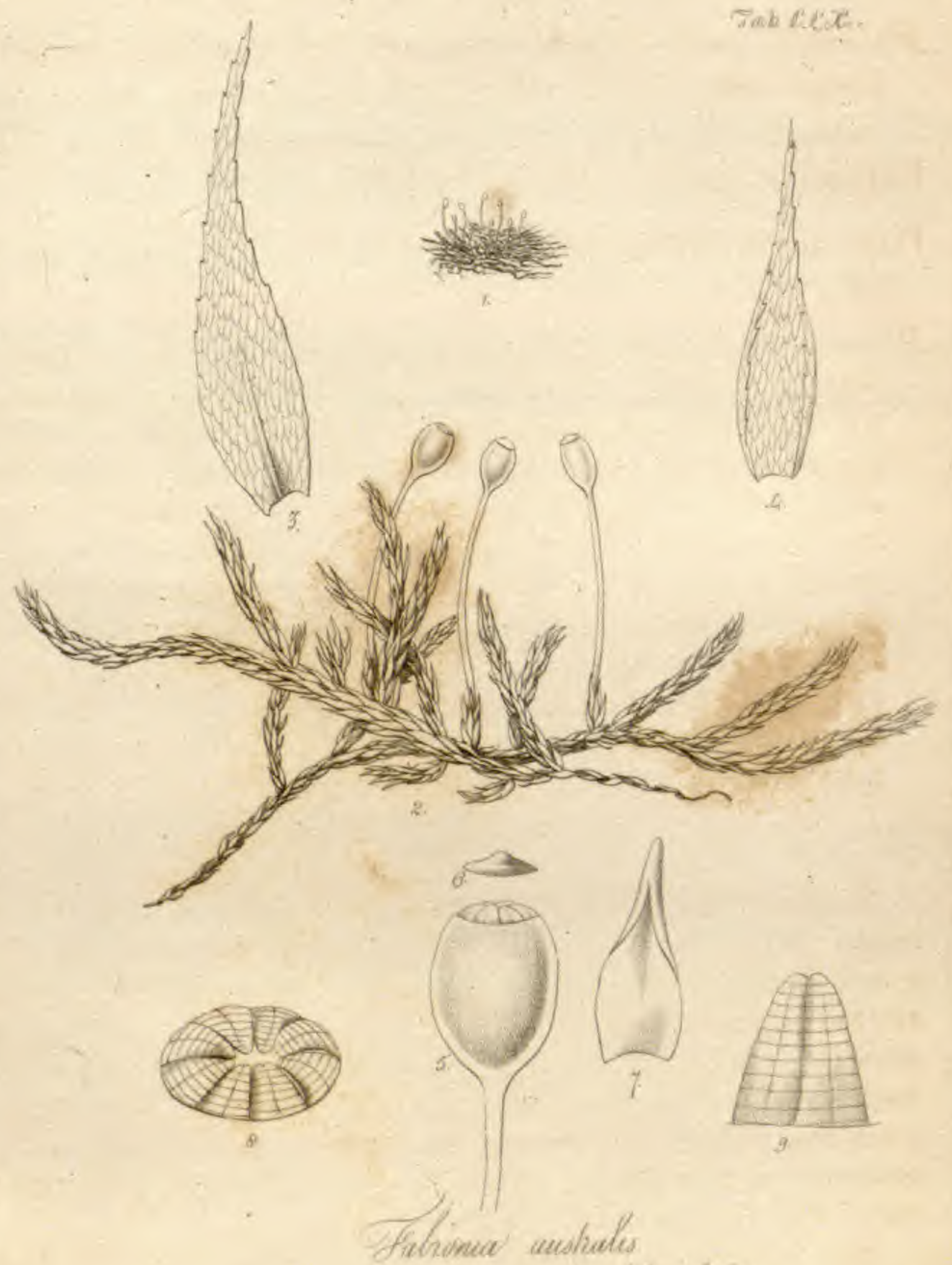

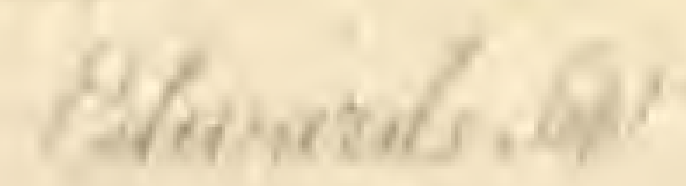




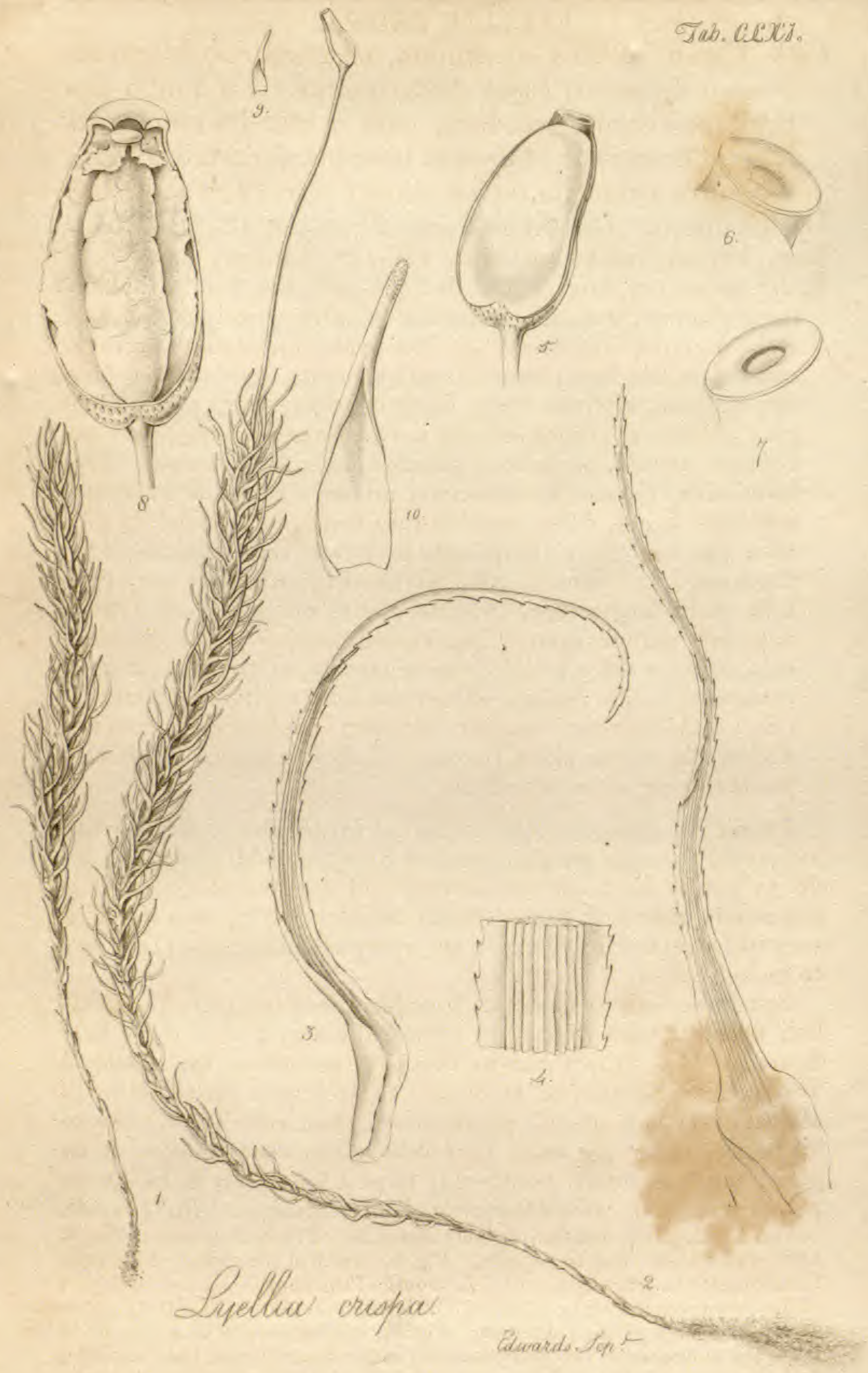




\section{LYELLIA CRISPA.}

Gen. Char. Stoma edentulum, clausum epiphragmate (crasso depresso) cujus discus circularis a limbo (latiori) persistente secedens, cum columella remanenti inclusa cohæret. Capsula hinc plana, inde convexa. Calyptra cucullata (apice pilosa). $B r$. (TAB. CLXI.) Lyellia crispa. Brown in Linn. Trans. v. 12.p.562. HAB. Nepaul, Indiæ Orientalis. Hon. D. Gardner. Radix tomentosa, fusca. Caulis 3-4-pollicaris fere ad palmarem, simplex, erectus, flexuosus, superne præcipue foliosus. Folia undique vergentia e basi late ovata, membranacea, vaginantia, pallide fusea, longe lineari-subulata, rigida, fusco-viridia, flexuosa, siccitate torta, dorso convexa, supra plana, margine pallidiore, argute serrata, nervo, totam fere paginam occupante, striato, oculo bene armato lamellato, percursa. Seta terminalis, biuncialis, rufescens, nitens, Capsula paululum reclinata, ovata, dorso convexo rufo-fusco, basi paululum gibbosa, punctis oblongis majusculis perforata; facie superna plana, flavo-fusca, marginata, collo perbrevi cylindraceo; ore, capsula multo angustiore, omnino clauso epiphragmate crasso, depresso, pallide fusco, " ipso centro circulari plano, crassiusculo, fusco, a disco pallido mox separante, arcte cum columella cohærenti, eaque demum abbreviata intra cavitatem retracto." (Br.) Membrana interior exteriori applicata, corrugata. Columella crassa plicis rugosa. Calyptra parva, dimidiata, pallide fusca, apice hispidula.

I willingly change, at the request of $\mathrm{Mr}$. Brown, a desire I had expressed to name another moss in honour of Mr. Lyell, in order to confer upon our excellent friend a genus of which it is impossible that any doubt should be entertained, and which is sure to be retained so long as the study of nature shall continue to be cultivated.

Specimens of this fine moss have been received from Dr. Wallich by Sir Joseph Banks, to whose liberality I owe those here figured. Mr. Brown has in the 12 th volume of the' Linnean Transactions written so much and so well upon the structure of almost every part of this plant, that I shall refer my readers to his paper, observing only, that although in the formation of its peristome it is totally unlike any moss I know, yet it has many points in common with Dawsonia, Polytrichum, and Buxbaumia.

Fig. $1 \& 2$, sterile and fertile plants, nat. size. Fig.3, 3, leaves. Fig. 4, section of a leaf. Fig. 5, capsule. Fig. 6, mouth of the capsule before the shrinking of the columella. Fig. 7, mouth of the capsule, the central part of the peristome having been drawn a little way into the cavity of the capsule by the shrinking of the columella. Fig. 8 , vertical section of a capsule to show the substance of the peristome, the internal membrane, the columella, and the centre of the epiphragma, which is withdrawn into the capsule. Fig. 9, calyptra, nat. size. Fig. 10, the same magnified,-all but fig. 1,2 and 9 , more or less magn.

VOL. II. 


\section{DAWSONIA POLYTRICHOIDES.}

Gen. Ghar. Perist. penicillatum, ciliis numerosissimis capillaribus rectis æqualibus e capsulæ parietibus columellæque ortis. Caps. hinc plana, inde convexa. Calypt. ext. e villis implexis, int. apice scabra. $B r$.

D. polytrichoides. Brown in Linn. Trans.v. 10.p.316. tab.3.f.1. (TAB. CLXII.)

$H_{A B}$. Ripæ subumbrosæ rivulorum, ad radices montium, in vicinitate Portưs Jackson, Novæ Hollandiæ. D. Brown.

Radix tomentosa. Caules $3-4$-unciales, simplices, erecti, flexuosi, basi nudiusculi, superne foliosi. Folia e basi dilatata, membranacea, fusca, lineari-subulata, supra plana, subtus convexa, patentia, siccitate erecto-appressa, fusco-viridia, margine dorsoque spinoso-denticulatis, nervo obsoleto, vix striato. Seta terminalis, vix unciam longa, rubra. Capsula madore horizontaliter reclinata, siccitate erecta vel paululum inclinata, rufo-fusca, supra plana vel basin versus etiam concava, subtus convexa, ore paululum contracto marginato. Calypira duplex; exi. e villis intertextis rufo-fuscis; int. triplo minor, membranacea, pallide fusca, supra longitudinaliter fissa, apice scabriuscula. Operculum eonico-eylindraceum, basi incrass3tum, apice lateris superioris mucrone subrecurvo. Peristominm penicillatum, densum, album, e margine capsulæ apiceque columella ortum ; ciliis numerosissimis, capillaribus, paululum flexuosis, inarticulatis. Columella angusta, corrugata.

I am happy to be able to figure this moss in the same number with the Lyellia, they having many points in common, especially the form of their capsules, although in the curious structure of the peristome and the shape of the operculum I know of nothing which resembles the Dawsonia. The male fiowers I have never seen ; but Mr. Brown has figured them, and given a most elaborate plate and description of the whole plant in the tenth volume of the Linncean Transactions.

Fig. 1, 1, plants, nat. size. Fig. 2, leaf. Fig. 3, capsule when dry. Fig. 4, ditto in a moist state. Fig. 5, operculum. Fig. 6, inner calyptra. Fig. 7, capsule cut open to show the columella and the insertion of the peristome. Fig. 8, eilia of the peristome.-magn. 
Tale cexys
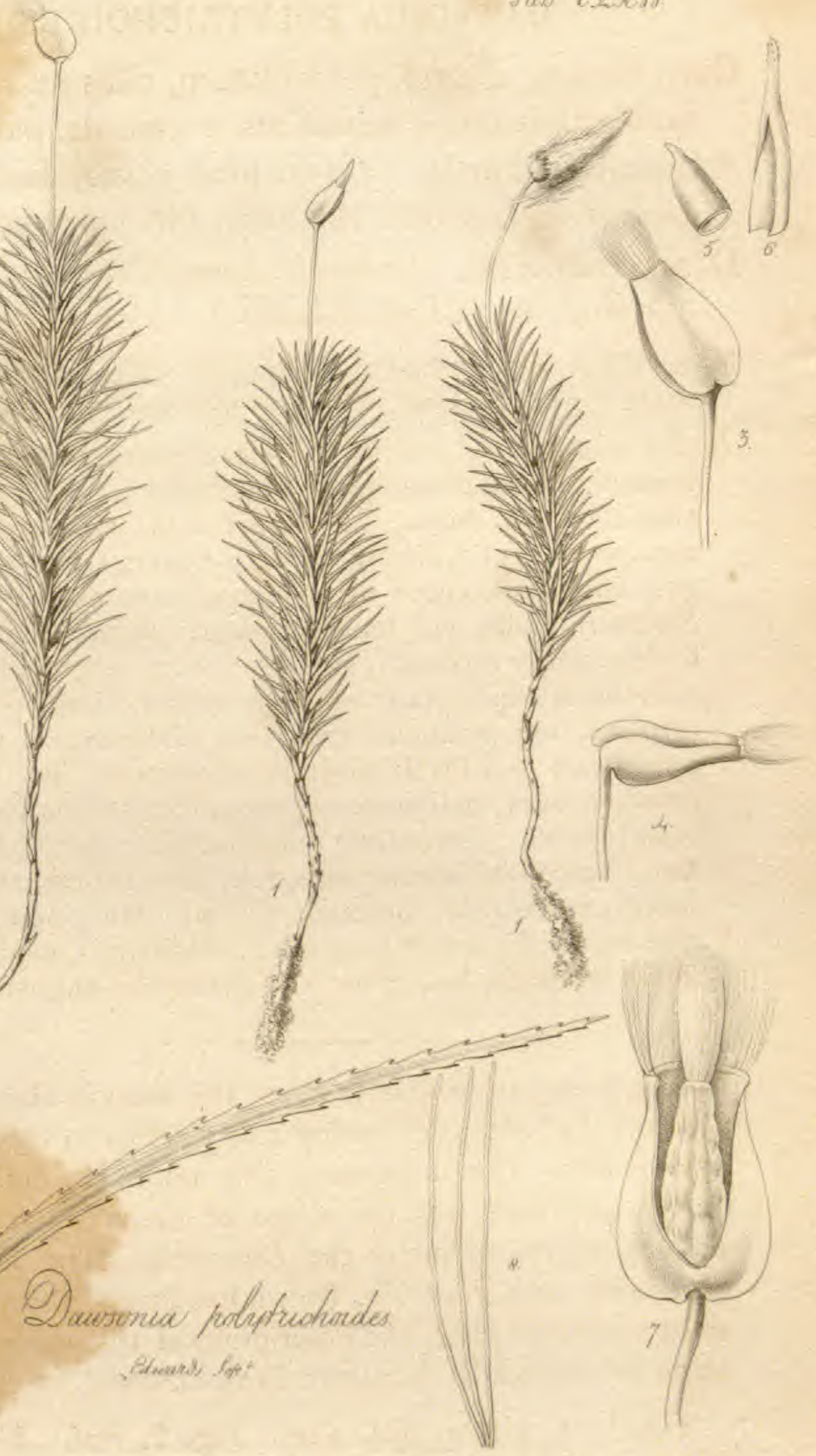


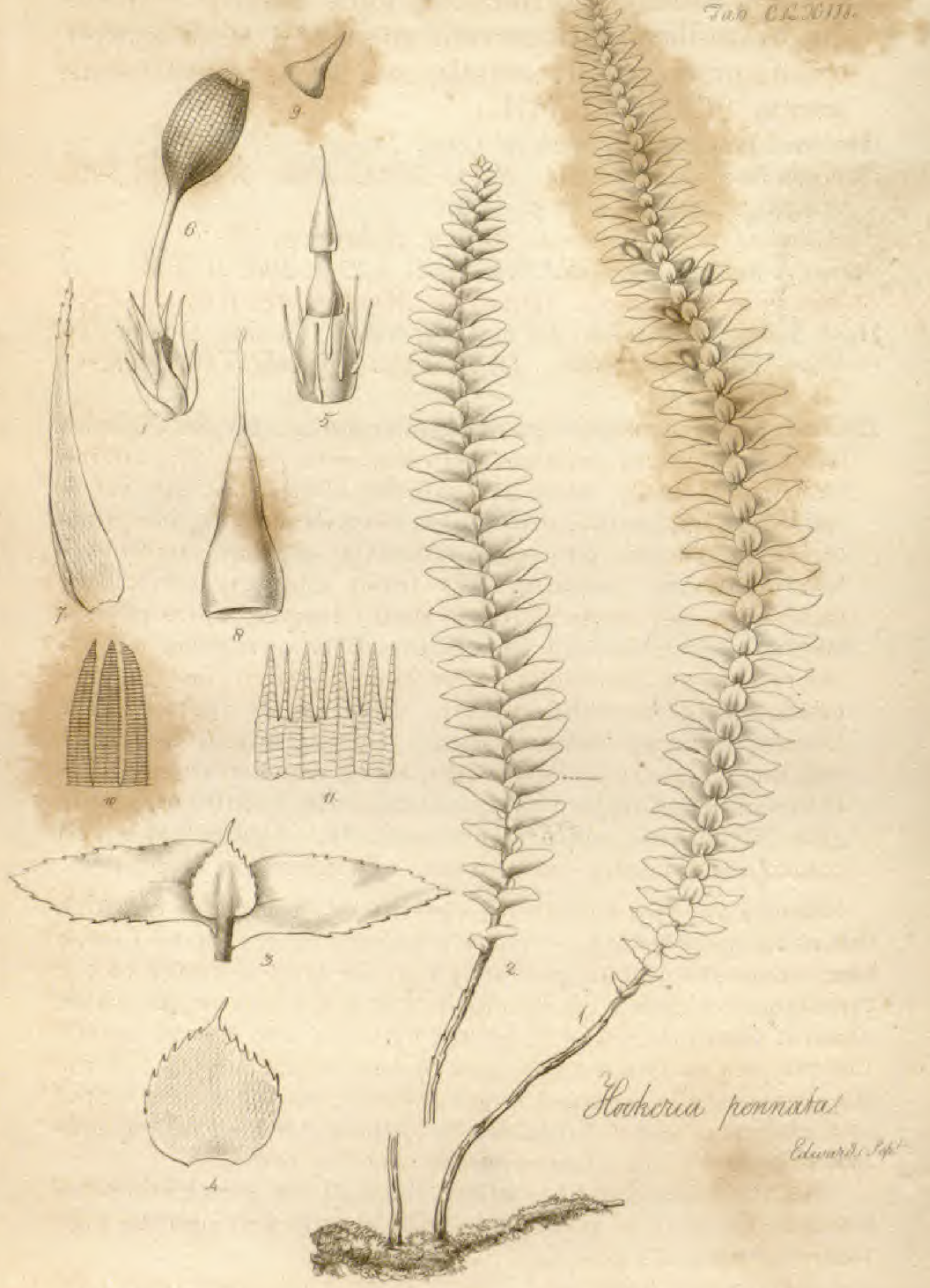




\section{Musci Exoтr cr.-Menziesiani.}

HOOKERIA PENNATA.

Hoolveria caule erecto simplice, foliis bifariis verticalibus ovato-lanceolatis serratis enervibus, stipulis orbiculatis mucronulatis serratis, seta brevi, capsula ovata erecta. (TAB. CLXIII.)

Hookeria pennata. Smith in Linn. Trans, v. 9. p. 277.

Pterigophorum pennatum. Brid. Meth. Nov. Musc. p. 149. Schwaegr. Suppl.v. 2. p. 160.

Cyathophorum pteridioides. Beauv. Elheog.p. 52.

Leskea pennata. Labill. Nov. Holl. v. 2. p. 206.t. 253. Anictangium bulbosum. Hedw. Sp. Musc. p. 43, t.6.f.1-5.

HaB. Nova Hollandia. D. Lalillardiere. In sinu Dusky Bay dicto, Nova Zeelandia. D. Menzies. Insula Van Diemen. D. Broun.

Radix repens, tomento fusco densissime obsita. Caules digitales fere ad palmarem, simplices (vel rarius divisi, Labill.), inferne nudi, nigri, nitidi. Folia flavo-viridia, bifaria, disticha, verticalia, laxe imbricata, horizontalia, ovato-lanceolata, inæquilatera, subpellucida, tenuissime reticulata, serrulata, basi obsolete uninervia. Stipula foliis triplo minores, orbiculatæ, cauli appressæ, denticulato-serrulatæ, enerves, apice mucronulatæ. Perichaelialia lanceolato-subulati, enervia, Perichretium in axillis stipularum, magnum, ovatum, fuscum, corporibus pistilliformibus obsitum. Seta stipula duplo triplove longior, curvata, basi incrassata. Capsula ovata, fusco-ferruginea, minute reticulata, erecta, vel ob setæ curvaturam paulo inclinata. Calyptra campanulata, inferne ventricosa, margine integerrima, apice stylo terminata. Operculum e basi conico acuminatum, acutissimum. Peristomium Hypni.

Scarcely any two authors are agreed as to the genus to which this noble moss belongs. Those who have referred it to Leskea have done so without understanding the true structure of the peristome, which is most decidedly that of a Hypnum, in which genus it would therefore be plazed by those who do not regard the calyptra as forming an essential generic character. To me it appears rightly arranged with Hookeria, having all the marks of that genus; and so Bridel seems to think, for his Pterigophyllum is precisely our Houkeria under another name.

After the fruitstalks have fallen, the bulbous perichætium remains in the axil of the stipule, and may at first sight be mistaken for the male flowers.

Fig. 1, plant, front, and Fig. 2, ditto, back, view, nat. size. Fig. 3, leaves and stipule. Fig. 4, stipule. Fig. 5, young capsule with its perichætium and calyptra. Fig. 6, capsule and perichætium. Fig. 7, perichætial leaf. Fig. 8, calyptra. Fig. 9, operculum. - magn. 


\section{Musci Exотісі-Browniani.}

\section{LESKEA SULCATA.}

Leskea caule erecto superne ramoso, ramis pinnatis, foliis undique imbricatis erectis appressis ovato-cordatis acutis striatis, nervo attingente, seta breviuscula, capsula cylindracea sulcata, operculo rostrato. (TAB. CLXIV.)

HaB. Portus Jackson, in Nova Hollandia. D. Brown.

Radix repens, densissime tomentosa, nigro-fusca. Caules digitales et ultra, erecti, inferne simplices, nudi, nigri, nitidi, superne ramosi, ramis elongatis pinnatis. Folia intense viridia, undique arcte imbricata, appressa, ovato-cordata, concava, acuta, minutissime serrulata, longitudinaliter substriata, nervo ad apicem attingente vel paululum excurrente instructa. Perichcetialia lævia, nervo obscuro ; exteriora ovata subacuminata, interiora longe acuminata vix serrulata, basi vaginantia. Seta breviuscula, flavo-rufa. Capsula magna, speciosa, flavofusca, cylindracea, profunde sulcata. Operculum conico-rostratum. Calyptra lateraliter fissa. Peristomium in meis speciminibus vix perfectum, sed Leskece videtur.

This very handsome moss comes in general habit nearer to our Hypnum dendroides than to any other that I know; yet it is very different even from that. In nothing, however, is it so remarkable as in the large cylindrical deeply sulcate capsule, and the long perichætial leaves compared with the shortness of the fruitstalk.

Fig. 1, plants, nat. size. Fig. 2, leaf. Fig. 3, 3, perichætial leaves. Fig. 4, fruitstalk and capsule. Fig. 5, calyptra. Fig. 6, outer, and Fig. 7, inner, teeth of the peristome.-magn. 
Tab cexiv.

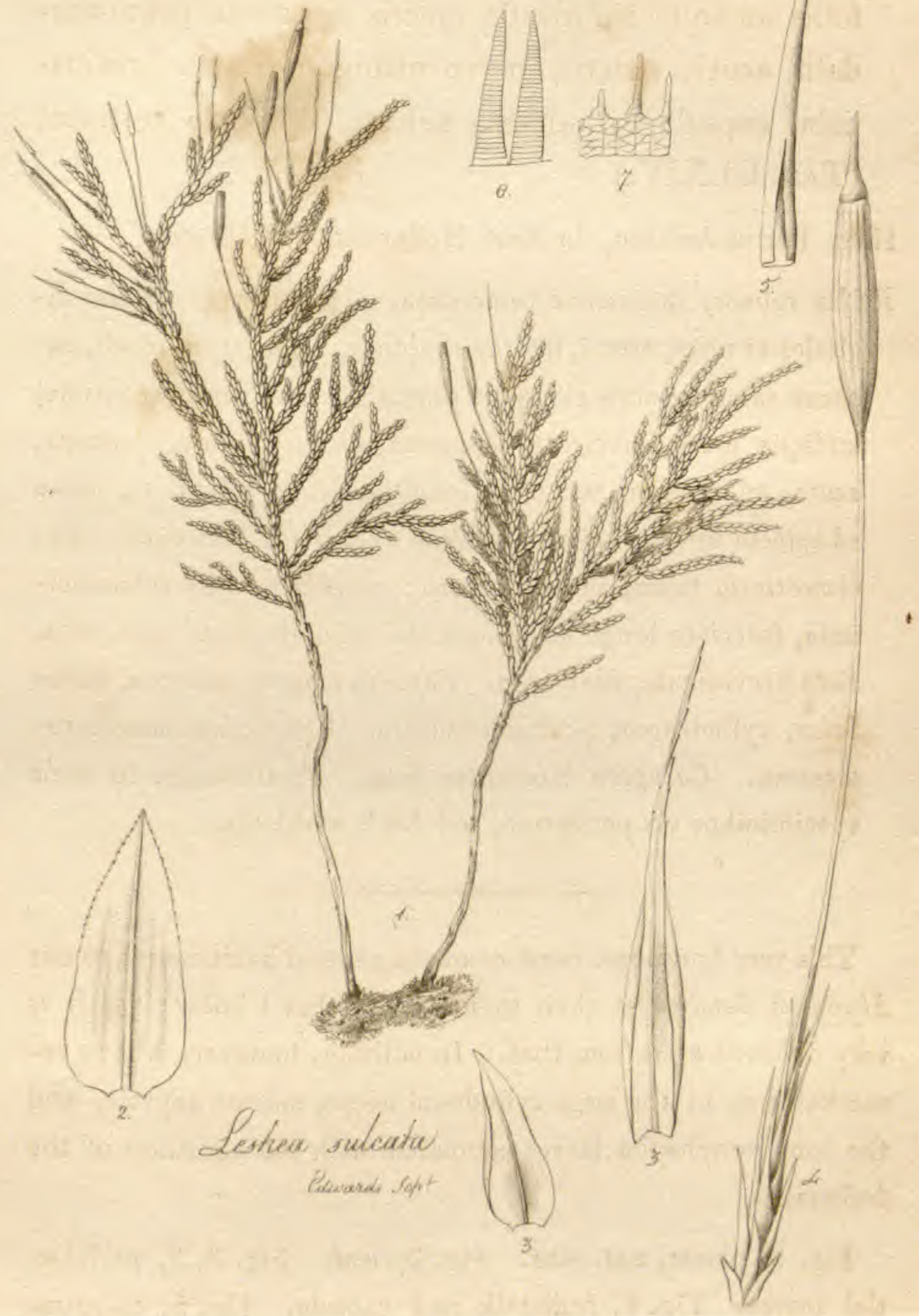




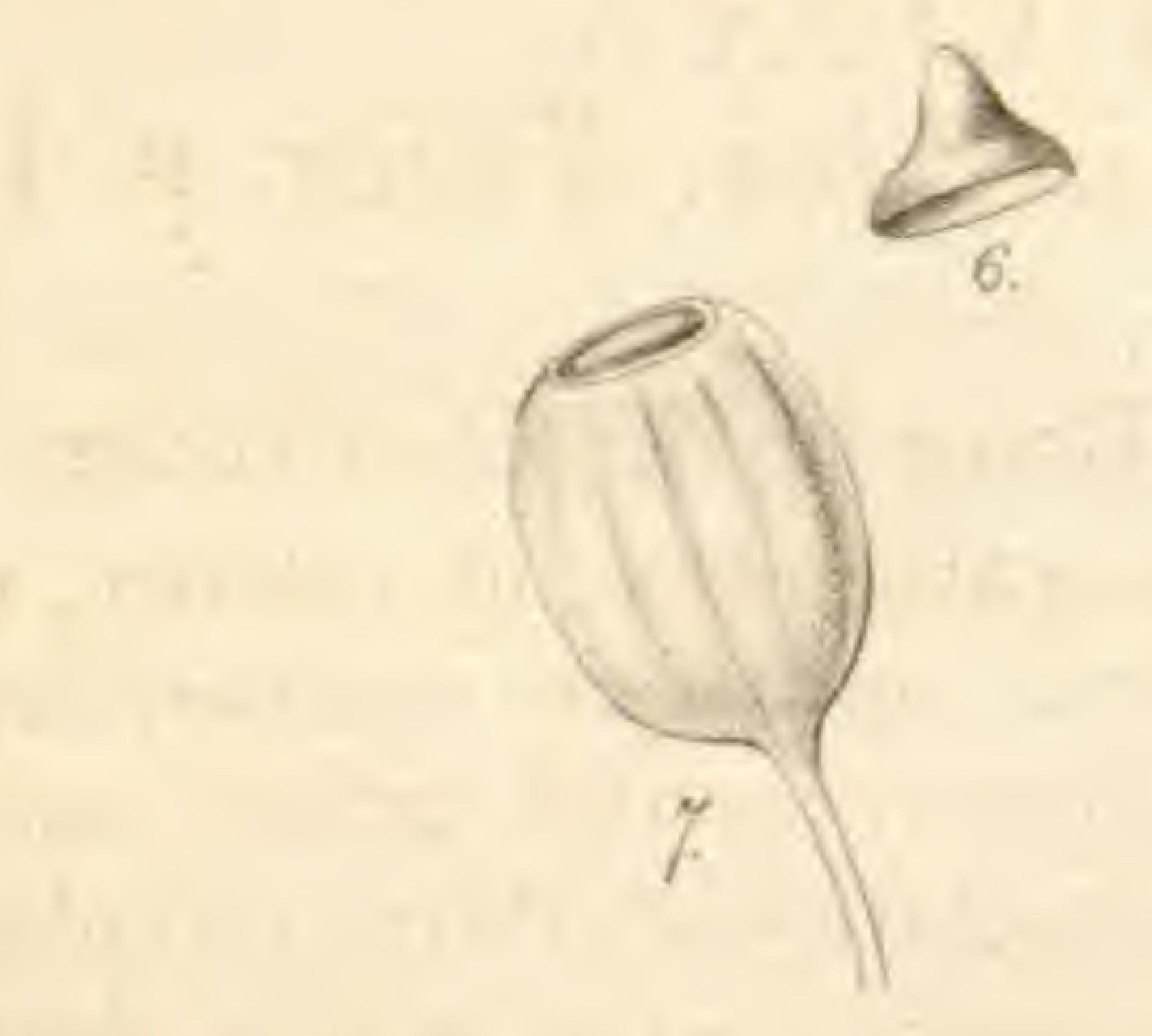

Juth acters
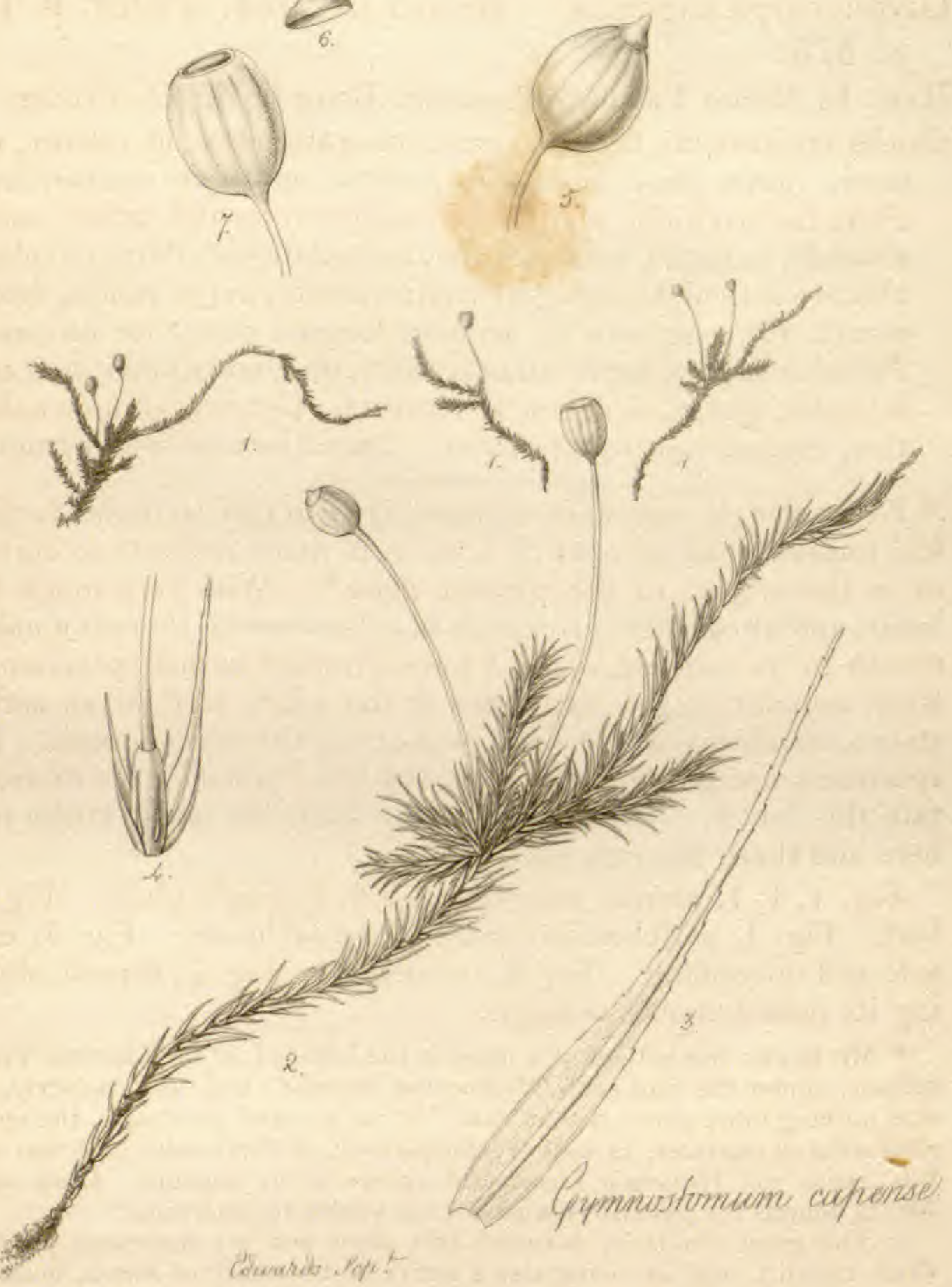
GYMNOSTOMUM CAPENSE.

Gymnostomum caule ramoso stolonifero, foliis undique vergentibus secundisque lanceolatis longe acuminatis subserratis, seta elongata, capsula sphærica striata, operculo conico acuto. (TAB. CLXV.)

Glyphocarpa capensis. Brown in Linn. Trans. v. 12. p. 575 .

Hab. In Monte Tabulari, Promont. Bonæ Spei. D. Brown.

Caules erectiusculi, flexuosi, vage, innovationibus, út vicletur, ramosi, ramis sæpe elongatis, inferue apiceque radicantibus. Folia fusco-viridia, plerumque undique vergentia, nunc, ramis, secunda, patentia, subsquarrosa, lanceolato-subulata, serrulata, obscure reticulata, margine subincrassata, nervo valido, fuscescente, ultra apicem in acumen longum desinente instructa. Perichatialia reliquis minora. Seta, ob imnovationes, non raro lateralis, erecta, flexuosa, vel curvata. Capsula omnino sphærica, erecta, sulcata, ore nudo. Operculum conico-acutum.

I exceedingly regret the being obliged to give so unsatisfactory and imperfect an account of a moss in many respects so curious as is the subject of the present plate*. With very much the habit, and altogether the capsule of a Bartramia, there is a naked mouth to the capsule, or, as I have observed in one specimen, a white annular jagged membrane at the edge, as if in an earlier state a membrane might have gone across the whole mouth. My specimens are too few, however, and too ivjured for me to ascertain this fact $\uparrow$. The long creeping branches which strike root here and there are very curious.

Fig. 1, 1, 1, plants, nat. size. Fig. 2, single plant. Fig. 3, leaf. Fig. 4, perichætium and perichætial leaves. Fig. 5, capsule and operculum. Fig. 6, operculum. Fig. 7, capsule showing its naked mouth.-magn.

* Mr. Brown has noticed this moss in the 12th vol. of the Linnæan Trans. actions, under the name of Glyphocarpa capensis; but, unfortunately, has said nothing more about it than that "it has a naked peristome, the sphærical striated capsules, as well as inflorescence, of Bartramia;" and that with this genus my Hedwigia Humboldtii agrees in its capsule. Upon what $\mathrm{Mr}$. B. founds his generic character I am unable to determine.

$\uparrow$ The great similarity between this plant and my Bartramia quadrata (Tab. exxxii.), and its being also a native of the south of Africa, made me feel curious to know if the structure of the mouth of the capsule might not be the same in that. I accordingly sacrificed almost the only remaining one in $\mathrm{Mr}$. Burchell's collection, and was not a little gratified at finding that it was entirely destitute of teeth; having, however, a very eviden horizontal membrane, closing the entire mouth. That plant must therefore be removed from Burtramia, and placed with this for the present; from which it differs in its much larger size, narrower leaves, and constantly quadrate capsule. 


\section{LESKEA MARITIMA.}

Leskea caule erecto subsimplice, foliis undique imbricatis arcte appressis late ovatis acuminulatis concavis enervibus integerrimis, seta elongata, capsula cylindracea erectiuscula.

(TAB. CLXVI.)

\section{Leskea maritima. Burchell's MSS.}

$\mathrm{H}_{\mathrm{AB}}$. Terrestris, in fruticetis arenosis in littore Sinus Plettenbergii in territ. colon. C. Bonæ Spei, copiose. D. Burchell.

Caules dense cæspitosi, erecti, paululum flexuosi, simplices vel subdichotome divisi. Folia nitentia, flavo-viridia, undique imbricata, erecta, appressa, valde concava, late ovata, acuminulata, margine omnino integerrima, enervia. 'Perichailialia minuta. Perichcetium hirsutum. Seta lateralis, elongata, gracilis, flexuosa, pallide flavo-rufescens. Capsula gracilis, cylindracea, paululum inclinata. Peristomium flavum; ext. dentibus 16, lanceolatis, linea media longitudinali notatis; int. membrana 16-dentatum.

The very erect and thickly-tufted mode of growth of this moss is very remarkable. In the disposition of the leaves it resembles Hypnum moniliforme, H. trifarium, H. Alexile, and Leskea ericoides; and near the latter it will naturally enough rank. The whole plant is very brittle, but particularly the fruitstalk.

Fig. 1, plants, nat. size. Fig. 2, single plant. Fig. 3, leaves. Fig.4, perichætium. Fig. 5, leaf of ditto. Fig. 6, eapsule. Fig. 7, outer, and Fig. 8, inner, teeth of peristome.$\operatorname{magn}$. 
Fak CSCDX.

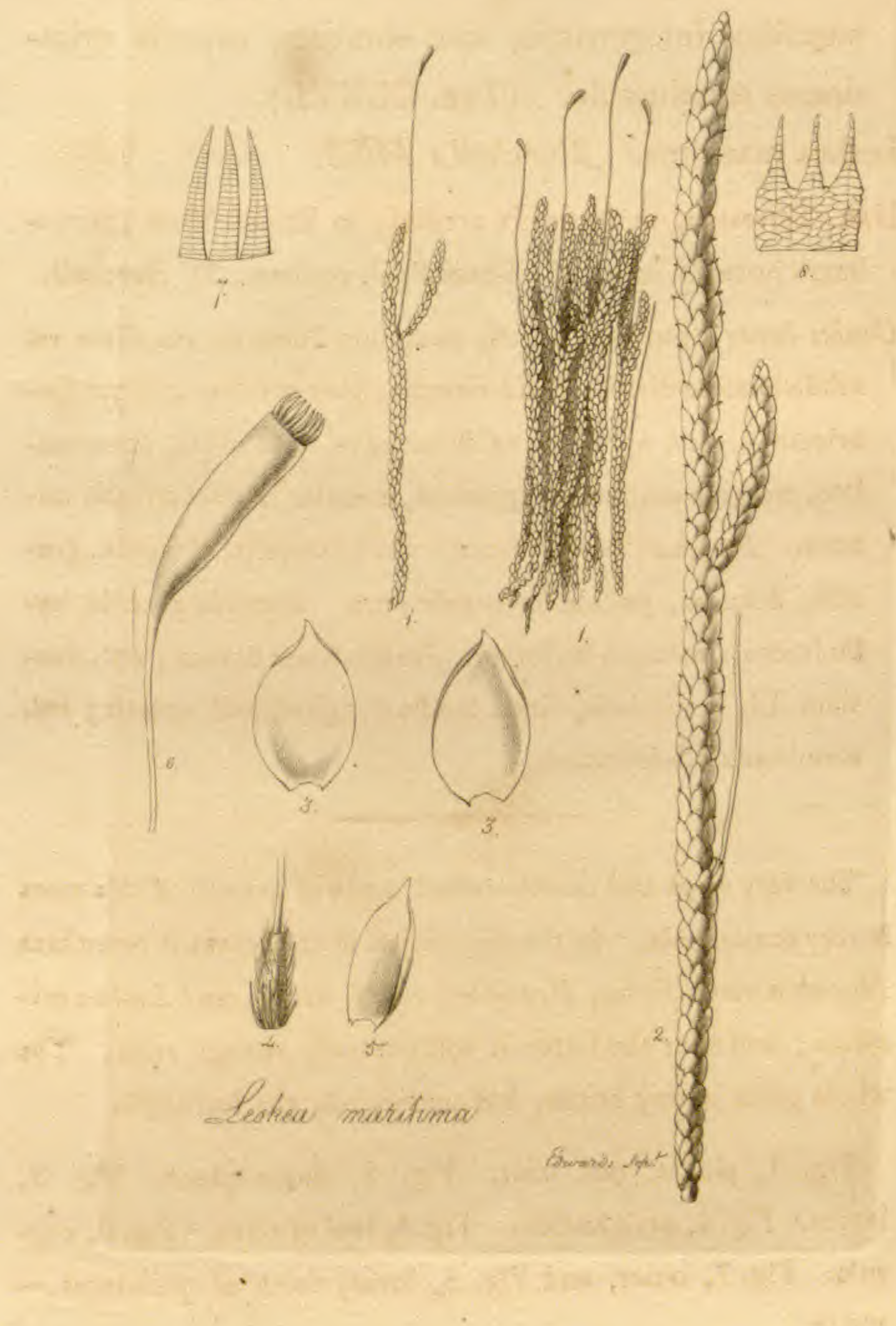


Fob CECVH.

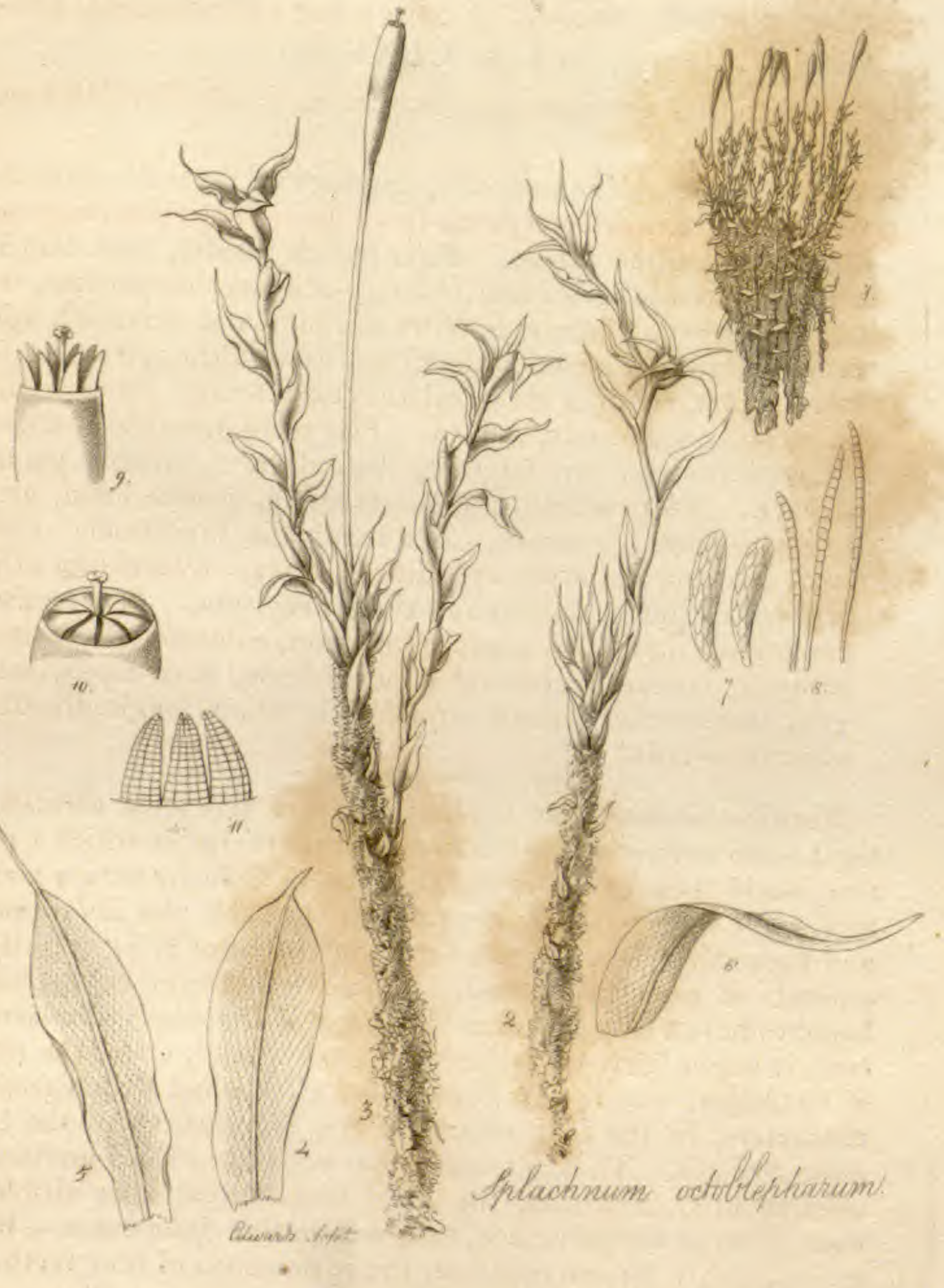




\section{SPLACHNUM OCTOBLEPHARUM.}

Splachnum foliis oblongo-obovatis integerrimis superioribus piliferis, capsula apophysique cylindraceis, dentibus 8 integris. (TAB. CLXVII.)

HAB. In truncis arborum emortuarum in Insula Van Diemen. D. Broun.

Caules subunciales, laxe cæspitosi, simplices vel innovationibus divisi, inferne tomento purpureo-fusco densissime obsiti, superne innovationibusque foliosi. Folia pallide viridia, laxe imbricata, patentiuscula, flexuosa, oblongo-obovata, integerrima, reticu!ata, inferiora latiora, breviter acuminulata, nervo sub apicem evanescente, superiora longiora, nervo ultra apicem in pilum longum, rigidum vix serrulatum excurrente. Perigonialia lanceolata, acuminata, refiexa. Flos masc. terminalis, sed ob innovationes non raro lateralis, discoideus. Antherce parvæ, clavatæ. Fila succulenta numerosissima, pallide fusca, articulata, sursum incrassata. Seta terminalis, breviuscula. Capsula, una cum apophysi, cylindracea, fusca. Operculum calyptraque desunt. Columella exserta, capitata. Peristomium paulo intra marginem capsula insertum, e dentibus 8 siccitate incurvis, madore erectis vel etiam reflexis, flavo-fuscis, integris, transversim striatis atque lineis tribus longitudinalibus obscure notatis.

Notwithstanding that the peristome of this moss consists of eight teeth only, - at least in the perfect specimens which I possess, - and these as entire as the teeth of Octollepharum serratum,-yet the plant has so completely the habit of a Splachnum, and especially of S. angustatum, that I cannot bring myself to separate it from that genus. Should it however be hereafter found to have a calyptra resembling that of Octoblepharum serratum, it might fairly be ranked with that species, under the name of Orthodon, which Mr. Brown has established with excellent characters, in the 12th volume of the Transactions of the Linnæan Society. That gentlenan has noticed, what I omitted to observe in $O$. serratum, the three longitudinal lines visible in each tooth of the peristome, as is seen in this Splachnum, -indicating, as Mr. Brown observes, the coalescence of four teeth.

Fig. 1, plants male and female, nat. size. Fig. 2, male plant, and Fig. 3, female ditto. Fig. 4, lower, and Fig. 5, upper, stem leaves. Fig. 6, perigonial leaf. Fig. 7, anthers. Fig. 8, succulent filaments. Fig. 9, capsule, with the teeth erect. Fig. 10, eapsule, with the teeth arched over the mouth, as seen when inoist. Fig. 11, teeth of the peristome,-magn. 


\section{GYMNOSTOMUM INCLINANS.}

Gymnostomum caule cæspitoso subsimplici, foliis ovatooblongis obtusis integerrimis nervosis piliferis, capsula ovato-oblonga horizontaliter inclinata. (TAB. CLXVIII.)

Leptostomum inclinans. Brown in Linn. Trans. v. 10. p. 320 .

НАв. Rupes et saxa ad latus orientale prope summitatem Montis Tabularis, Lat. Austr. $43^{\circ}$, elevatione supra mare 3000 ad 3,500 ped. Insula Van Diemen. D. Brown.

Caules densissime crespitosi, subsimplices, inferne tomento denso fusco ferrugineo obsiti, superne foliosi. Folia arcte imbricata, erecta, flavo-viridia, sub lente punctulata, ovato-oblonga, valde obtusa, marginibus integerrimis non raro revolutis, nervo valido in pilum satis longum flexuosum ultra apicem producto instructa. Perichcetialia angustiora, marginibus magis reflexis, pilo longiore terminata. Seta pollicaris, flexuosa, flavofusca. Capsula ovato-oblonga, basi attenuata, rufo-fusca, horizontaliter inclinata, ore subcoarctato, intus membrana annulari, suberecta, alba, margine subdentata instructo. Operculum conico-hemisphæricum.

This borders very closely upon Gymnoslomum gracile (Leptostomum $\mathrm{Br}$.) already figured in this work. It is however a much more robust plant, having larger stems, which for nearly their whole length are covered with thick, deep-brown, ferruginous downy radicles, having at their summit a short thick tuft of leaves, and exhibiting in various parts of their length the terminal tufts of former years; so that the plant increases in length by its annotinous shoots, like many of the Bartramia. The fruitstalk too is shorter than in G. gracile, the capsule larger and more ovate, and the leaves are more obtuse, with shorter hairs.

The membrane which constitutes Mr. Brown's character of Leptostomum is here rather erect than horizontal, and the edge jagged; there is too a faint appearance of longitudinal lines like the cohesion of short obtuse and irregularly-formed teeth; but as I had only one specimen to examine, I cannot speak with that certainty of its structure that I could wish.

Fig. 1, tuft of plants, nat. size. Fig. 2, single plant. Fig. 3, 3, leaves. Fig. 4, perichætium. Fig. 5, leaf of ditto. Fig. 6, portion of a leaf, to show the minute cellules. Fig. 7, capsule. Fig. 8, operculum. Fig. 9, mouth of the capsule showing the annular membrane.-magn. 
Jab cexway.

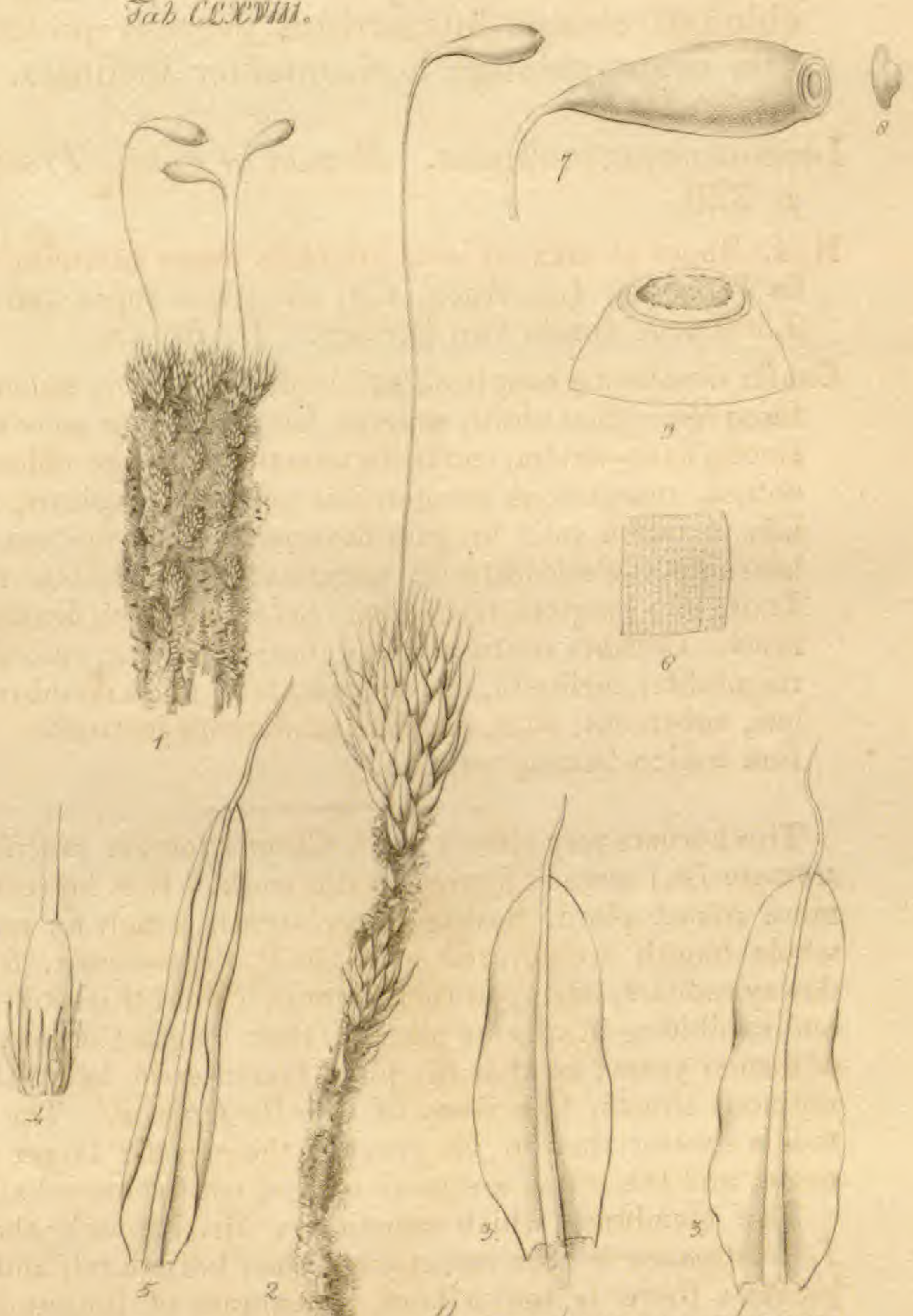

Prymongy 
sad ascin
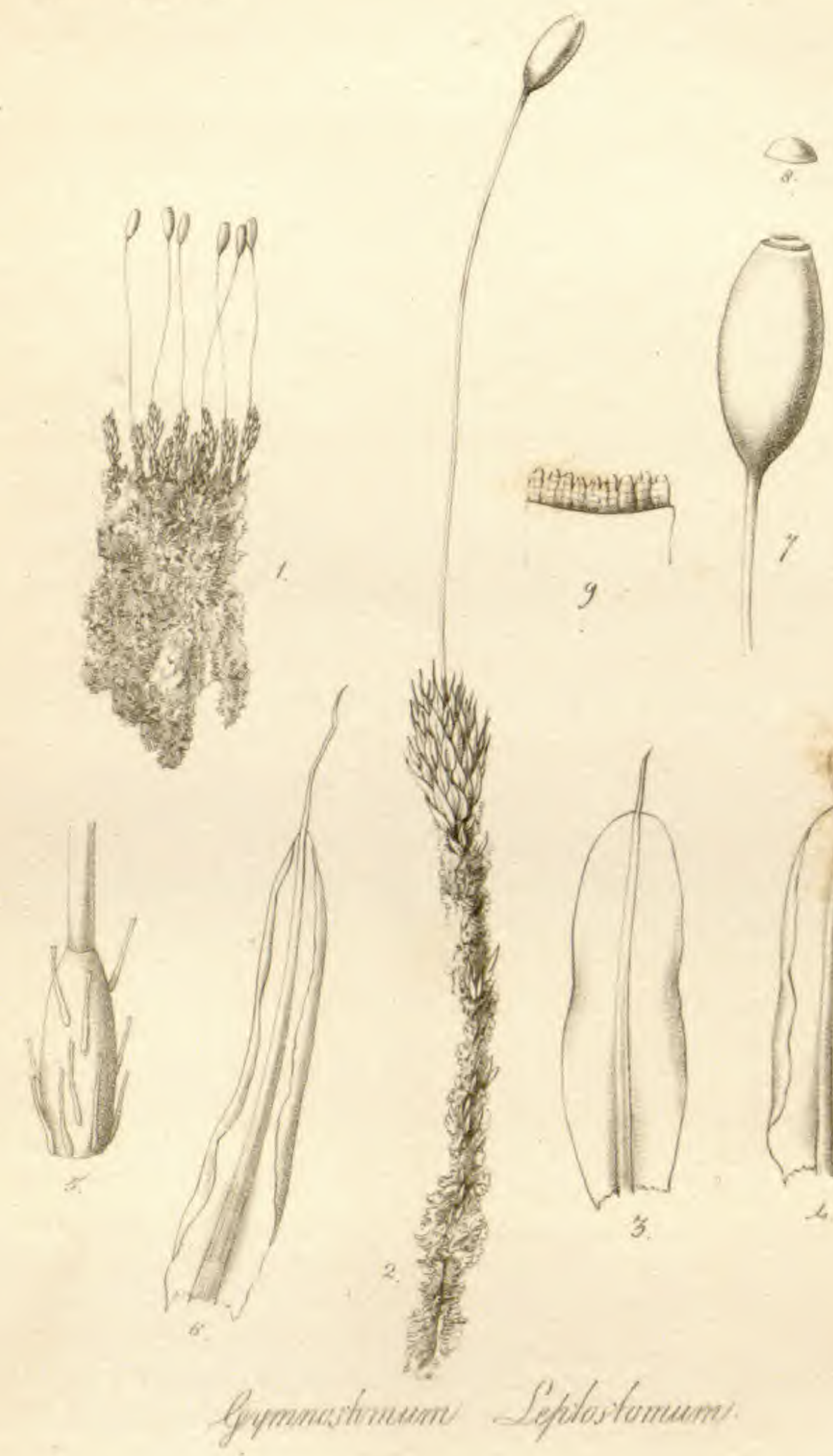


\section{Musci Exотісі.-Browniani.}

\section{GYMNOSTOMUM LEPTOSTOMUM.}

Gymnostomum caule crespitoso subsimplice, foliis oblongis obtusissimis integerrimis nervosis pilo simplice terminatis, capsula ovata erecta. (TAB. CLXIX.) Leptostomum erectum. Brown in Linn. Trans.v. 10. p. 320 .

НАв. Novæ Hollandiæ ora orientalis, extra tropicum, in rupes prope fluviorum ripas in regione montana, ad fluvios Hawkesbury et Grose. D. R. Brown.

Caules densissime caspitosi, inferne tomento ferrugineo obsiti, superne foliosi. Folia parva, læte viridia, sub lente punctulata, dense imbricata, erecta, siccitate tortilia, oblonga, obtusissima, vix concava, marginibus integerrimis recurvis, nervo valido ultra apicem in pilum breviusculum flexuosum producto instructa. Perichatialia angustiora, longiora, marginibus magis recurvis. Seta unciam longa, flavescens. Capsula erecta, ovata, fusca, ore paululum contracto, intus membrana suberecta pallide flavescens, margine dentata, longitudinaliter lineata, lineis subæquidistantibus, intra has lineis transversalibus. Operculum parvum, hemisphæricum.

Being possessed of better specimens of this than of the other species of Leptostomum of Mr. Brown, I was enabled the more satisfactorily to examine its peristome; and I am clear, in this species at least, that it is divided by longitudinal and nearly equidistant lines; an indication of teeth; and indeed the membranous substance between them at the extremity is produced more or less in every instance, and is for its whole length transversely striated. This structure is the more important, because it precisely agrees with a sketch which I made some years ago of the peristome of Hedwig's Bryum macrocarpum in Mr. Turner's herbarium; and it has not escaped the observation of $\mathrm{Mr}$. Brown, that that plant is very closely allied to his Leptostomum, and that Hedwig's figure of the peristome is probably very incorrect.

To the present species in particular, Bryum macrocarpum is certainly in other respects very closely allied, particularly in the upright capsules and the great revolution of the margins of the leaves. There is, indeed, a very peculiar habit in all the Leptostoma of Mr. Brown.

Fig. 1, tuft of plants, nat. size. Fig. 2, plant. Fig. 3, upper side of a leaf. Fig. 4, under side of ditto. Fig. 5, perichætium. Fig. 6, leaf of ditto. Fig. 7, capsule. Fig. 8, operculum. Fig. 9, portion of the peristome.magn.

VOL. II. 


\section{HEDWIGIA SCHMIDTII.}

Hedwigia caule procumbente ramoso, foliis undique imbricatis erectis ovato-acuminatis striatis integerrimis enervibus, capsula globosa, operculo subulato. (ТАB. CLXX.)

HAB. In sylvis umbrosis prope Laguna truncos et ramos arbustorum vestiens. Teneriffæ. D. Prof. Schmidt, 1815.

Caules digitales et ultra, procumbentes, flexuosi, vage ramosi, ramis attenuatis. Folia undique imbricata intense atro-viridia, superiora pallidiora, omnia dense imbricata, erecta, ovatoacuminata, integerrima, enervia, longitudinaliter striata, marginibus reflexis. Perichæetialia insigniter convoluta, exteriora minora, late ovata, subacuminata ; interiora prælonga, magis acuminata. Seta lateralis, sesquiunciam longa, flexuosa, rufofusca. Capsula exacte sphærica, erecta, ore contracto, intus membrana annulari alba. Operculum longirostrum, curvatum.

The annular membrane within the mouth of the capsule of this moss was noticed by its lamented discoverer Dr.Christian Schmidt, and it is very obvious in all the specimens which 1 possess. "Inter 1000 specimina (he further remarks) unicum modo calyptratum et operculatum detegere potui ;" but that calyptra, represented on the left hand specimen, is in too young a state to allow of my determining the exact figure of it. In habit this moss accords very satisfactorily both with Hedwigia Humboldtii and H. secunda, though it is still nearer perhaps to Leucodon sciuroides.

Fig. 1, 1, plants, nat. size. Fig. 2, 2, leaves. Fig. 3, perichætium. Fig. 4, outer leaf of perichætium. Fig. 5, inner ditto. Fig. 6, operculum. Fig. 7, capsule.-magn. 


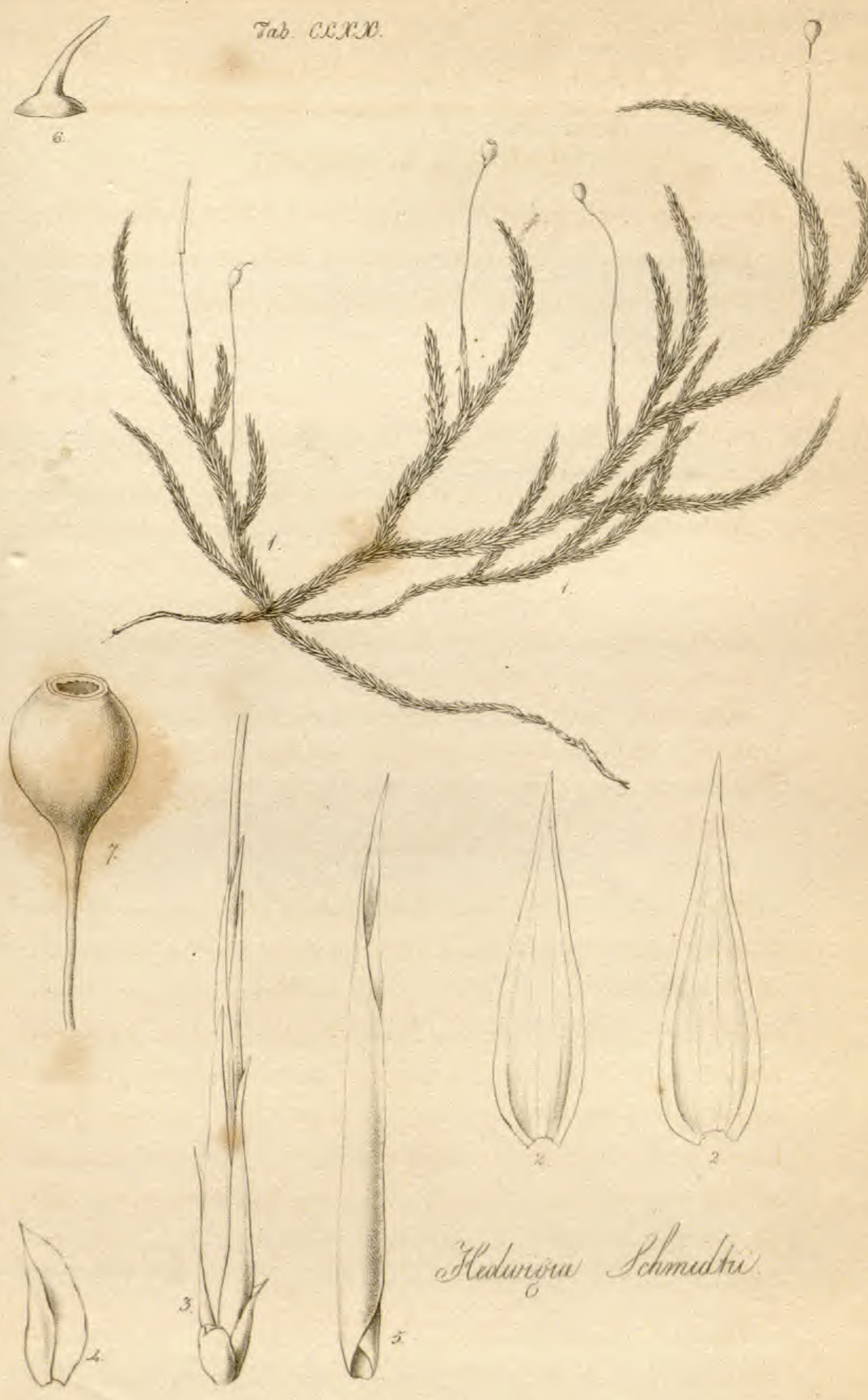



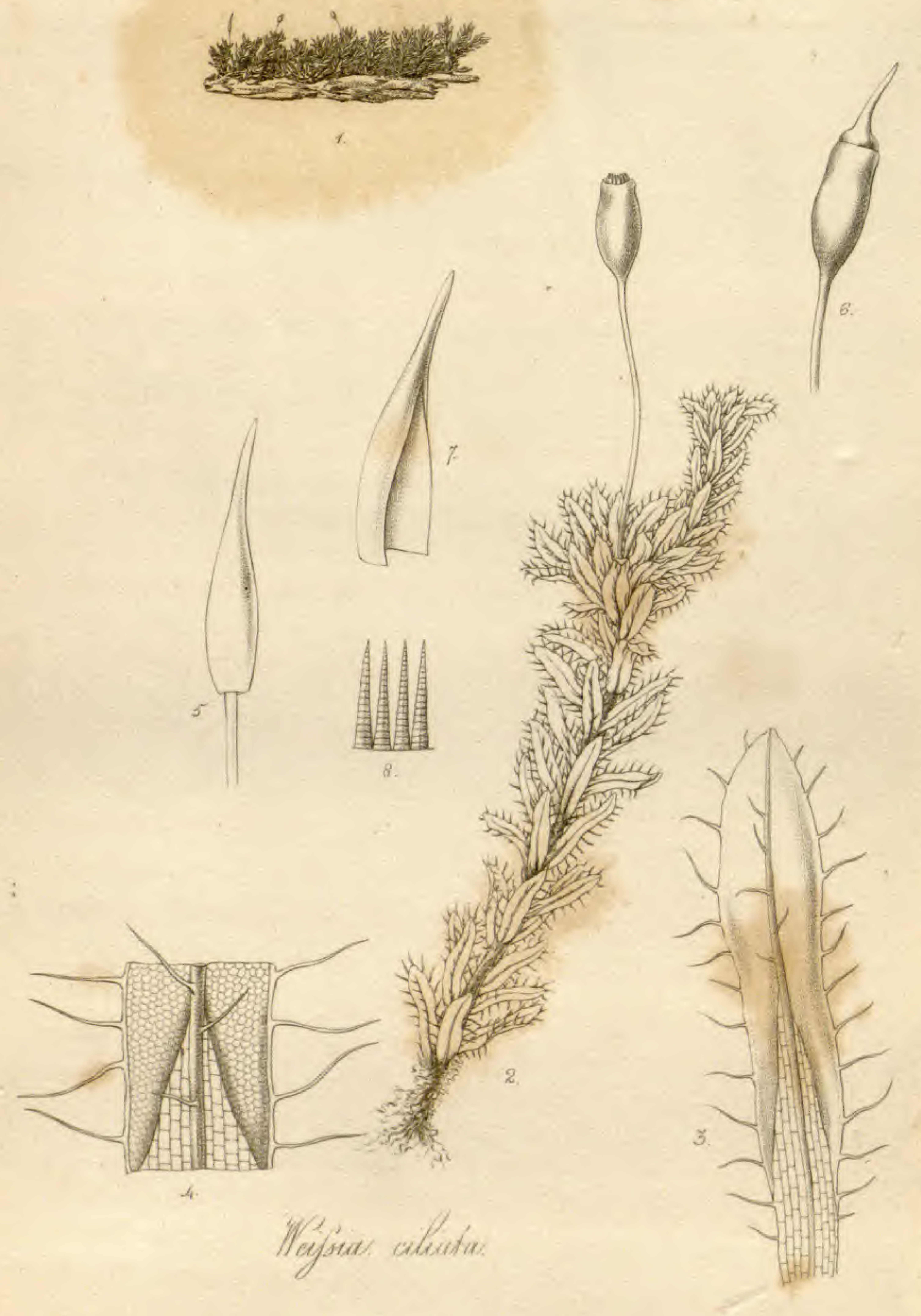


\section{WEISSIA CILIATA.}

\section{Weissia foliis lingulatis longissime ciliatis. (TAB. CLXXI.)}

HAB. Ex insula Ternatæ accepit D. Dicksonus.

Caules densissime cæspitosi, vix semiunciam longi, simplices vel innovationibus (ut videtur) ramosi, ferrugineo-tomentosi. Folia pallide viridia, laxe sed undique disposita, subflexuosa, lingulata, planiuscula, marginibus subinerassatis, undique nervoque superne, ciliis longissimis distantibus albis instructa. Substantia mollis, reticulata, areolis parvis, rotundatis, inferne membranacea, pellucida, pulcherrime reticulata, areolis magnis oblongo-quadratis. Seta terminalis, breviuscula. Capsula ovata, erecta. Operculum conico-rostratum, rostro capsula paulo breviore. Calyptra junior, integra, demum lateraliter fissa, dimidiata. Peristomium e dentibus 16 longiusculis.

A more singular or beautiful object for the microscope in the whole order of Musci does not exist than the subject of the annexed plate. There is a peculiar delicacy and transparency about the foliage, the lower part of which is singularly loosely cellular, and the margins and nerve above are beset with distantly placed hairs, in a manner totally unlike any other moss that I am acquainted with. The fructification seems to be rare. Among several specimens which I possess, I was able to find only one which had perfect fruit. It grows on half-decayed wood.

Fig. 1, tuft of plants, nat. size. Fig. 2, single plant. Fig. 3, leaf. Fig. 4, portion of ditto. Fig. 5, young calyptra. Fig. 6, capsuie and operculum. Fig. 7, fully formed calyptra. Fig. 8, teeth of the peristome,-magn. 


\section{LEUCODON PALLIDUS.}

Leucodon caule procumbente ramoso, foliis ovatis longe acuminatis concavis integerrimis, nervo pellucido attingente, seta longa flexuosa, capsula inclinata, operculo longe rostrato. (ТАв. CLXXII.)

\section{Hab. In Nova Hollandia.}

Caules procumbentes, ramosi, ramis erectis non raro subpinnatim ramosis. Folia pallide viridia undique imbricata, sæpe secunda, ovata, longe acuminata, obtusiuscula, integerrima, valde concava, nervo pellucido fere ad apicem attingente instructar Pericheetialia circumvoluta, exteriora caulinis subsimilia; interiora latissima, obtusa, fere enervia, pilo longo terminata. Seta subbiuncialis, flexuosa. Capsula subhorizontaliter inclinata, paululum curvata, ovato-cylindracea. Operculum rostratum, rostro capsula subæque longo, decurvo. $\mathrm{Pe}$. ristomium e dentibus 16 longis, infra medium fissis.

I had several times received specimens of this moss from my liberal friend Mr. Dickson, but without any precise habitat; I was therefore particularly glad to be supplied with it again from Mr. Hobson of Manchester, along with some other cryptogamie plants sent to him from the vicinity of Paramatta, New South Wales. It accords well with the character of Leucodon, (except indeed in the colour of the teeth, which only proves the badness of the name,) and will arrange naturally with $L$. calycimus and L. rugosus.

Fig. 1, 1, 1, plants, nat. size. Fig. 2, 2, leaves. Fig. 3, perichætium. Fig. 4, outer perichætial leaf. Fig. 5, inner ditto, Fig. 6, capsule. Fig. 7, teeth of the peristome, -magn, 


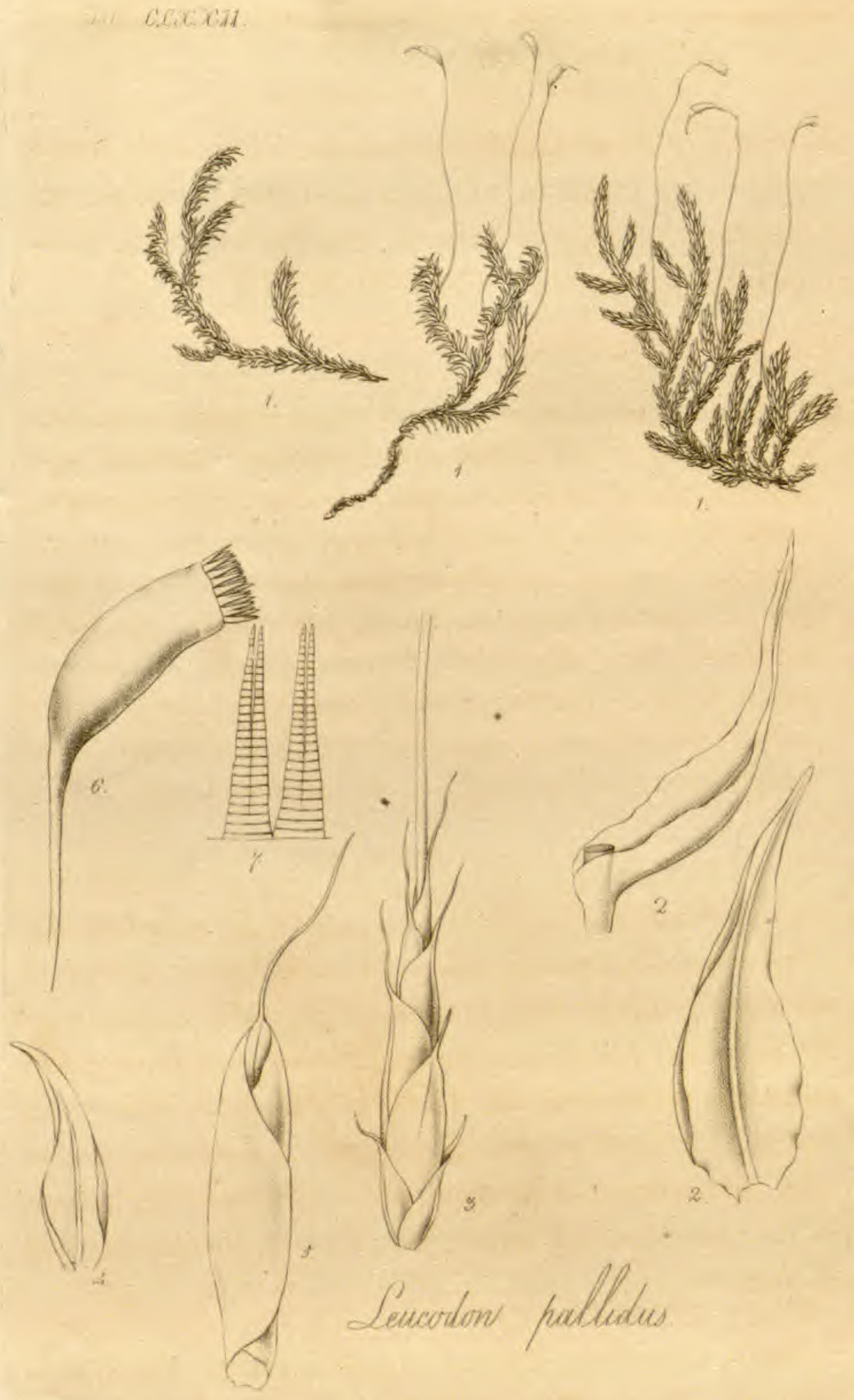




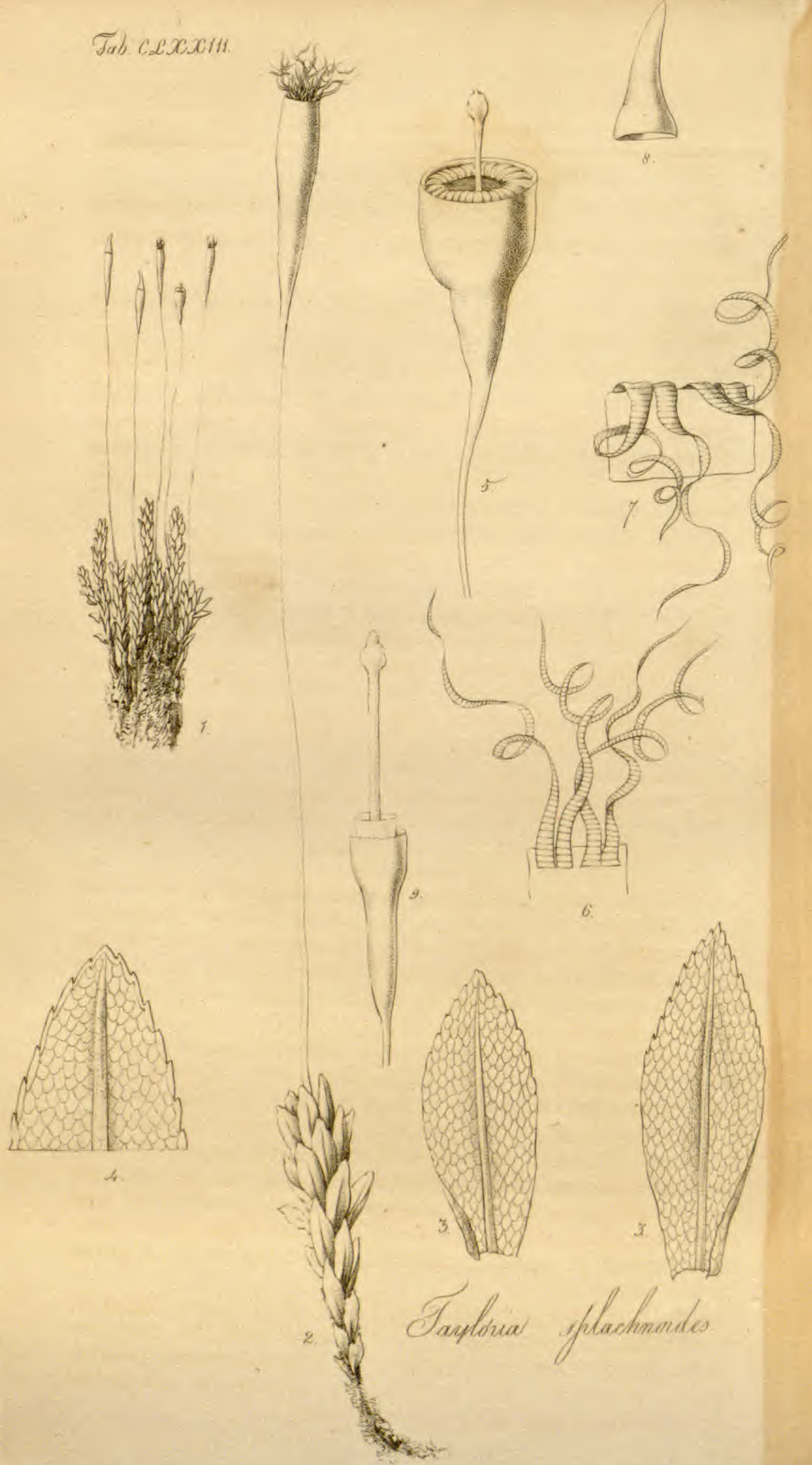


TAYLORIA SPLACHNOIDES.

Gen. Char. Perist. simplex, e dentibus 32 longissimis tortuosis per paria approximatis. Capsula apophysata. Tayloria splachnoides. (TAв. CLXXIII.)

Tayloria splachnoides. Hook. in Journ. of Science and the Arts, No. 3. p. 144.

Hookeria splachnoides. Schwaegr.Suppl.v.2.p.340.t.C.

Нав. Prope Rollvag, Tind, Tellemarkiæ, in Norvegia. D. Prof. Schmidt. Rupibus madidis in monte Grimsel dicto et prope Glacier du Rhóne Helvetiæ, altit. 5000 ped. 1814 . Helvetia. Schleicher, Seringe. In Tyroli australi. D. Lehmann. In summis alpibus Carinthianis. D. Prof. Hornschuch.

Caules plerumque cæspitosi, unciales, subsimplices, inferne ferrugineo-tomentosi. Folia imbricata, erecto-patula, ovatolanceolata, apice magis minusve obtusa atque serrata, laxe reticulata, luteo-viridia, nervo infra apicem evanescente instructa. Sela biuncialis, aur antiaca, nitida. Capsula oblongocylindracea, primum viridis, demum flavescens, apophysi capsula longiore sed angustiore basi attenuata insidens. Operculum conico-acuminatum, longitudine fere capsulæ. Columella capsulæ longitudinem excedens, filiformis, apice capitata. Peristomium simplex, e dentibus 32 infra marginem affixis, per paria approximatis, longissime attenuatis, tortuosis, rubris, transversim striatis, madore arcte involutis, demum valde mobilibus, vermicularibus, siccitate reflexis.

In the year 1816 I dedicated this new genus of mosses to my friend Dr. Taylor in the third number of Brande's Journal of Science and the Arts, and there gave a complete history of the plant. In the same year it was published, under the already occupied name of Hookeria, in Schwaegrichen's Supplement to Hedwig's Species Muscorum. That of Tayloria will, therefore, I trust, remain; and it is very much with the view of giving it greater publicity that I again represent it here. Nothing can be more curious than to see the teeth of this moss writhing about on the application of warmth to a specimen already saturated with moisture. They are admirably described by Schwaegrichen, when he says, "Dentes madore contorti, et thecæ margine appressi, siccitate diffusi, halitu observantis tacti singuli spirnliter sed laxe se contorquentes et rursus evolventes, semina dispergentes, continuo tremuli et mobiles, simili quodam motu ut fila Equiseti germen cingentia."

Fig. 1, tuft of plants, nat, size. Fig. 2, single plant. Fig. 3, 3, leaves. Fig. 4, apex of do. Fig. 5, capsule with the teeth involute as seen when moist. Fig. 6 and 7 , teeth variously twisted. Fig. 8, operculum. Fig. 9, columella; the capsule and part of the inner membrane being removed.-magn. 


\section{MONOCLEA FORSTERI.}

Gen. Char. Receptaculum fruetus commune nullum. Capsula pedunculo calyce longiori insidens, univalvis, hinc longitudinaliter dehiscens. Columella nulla. Monoclea Forsteri. (TAB. CLXXIV.) Anthoceros univalvis. Forster's MSS.

HAB. Insulæ australes. D. G. Forster (in Herb. Lambert.).

Frondes procumbentes, imbricatæ, subcongestæ, coriaceo-foliaceæ, crassiusculæ, succulentæ, planæ, suborbiculares, inæqualiter lobatæ, lobis late ovatis, obtusissimis, margine undulatis, sinuatis, crispis, enerves, atro-virides, superne glabræ, vix reticulatæ, subtus hirsutæ, medium versus radicibus longis fibrosis numerosis præditæ. Fructificatio e cavitate versus apicem frondium. Calyx nullus. Corolla intra frondem inclusa, tubulosa, apice bifida. Setæe sesquiunciales, carnoso-succulentæ, sordide flavæ, solitariæ, vel tres ex eadem cavitate.Capsula oblongo-cylindracea, fusca, striata, inclinata, dorso longitudinaliter dehiscens, demum post seminum emissionem in valvam oblongam coriaceam expansa. Semina et fila spiralia numerosa (ut in Jungermannia).

I know of no specimens of this highly curious plant, but those which exist in Mr. Lambert's herbarium, where they bear the MS. name of Anthoceros univalvis. There are no details, however, in that drawing; and I should have been ignorant of the true structure of the capsule, had it not been for some young fructification upon the specimens here figured. There were three capsules nearly risen above the surface of the frond, and it was here easy to see that the capsule is at first cylindrical, of one valve, and bursting at the underside by a longitudinal opening, whence the seeds and spiral filaments make their escape. After this, the valve is spread out, and becomes of an obovate figure. The three capsules which have scarcely risen above the surface of the frond, though burst, have probably done so from the effect of pressure and drying.

I have derived the name of this genus from povos one, and

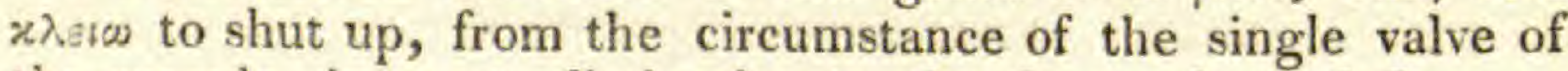
the capsule, in contradistinction to the four valves of Jungermannia, and the two of Targionia and Anthoceros, from which last genus it also differs in the want of a columella to which the seeds are attached.

Fig. 1, plant, nat. size. Fig. 2, capsule bursting. Fig. 3, capsule more advanced. Fig. 4, capsule empty, seen from the under or inner side. Fig. 5, ditto empty, seen from the upper or exterior side. - magn. 


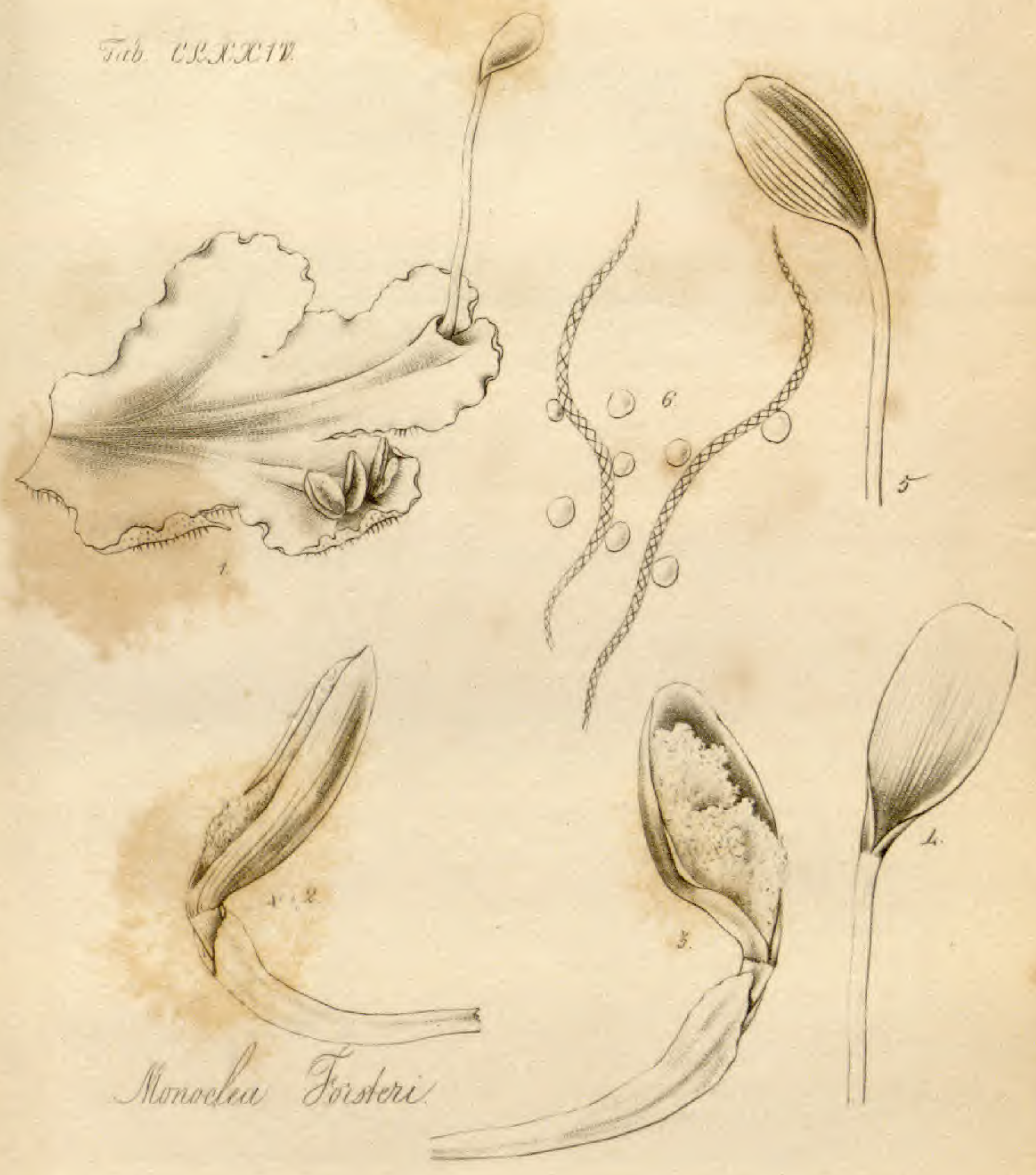



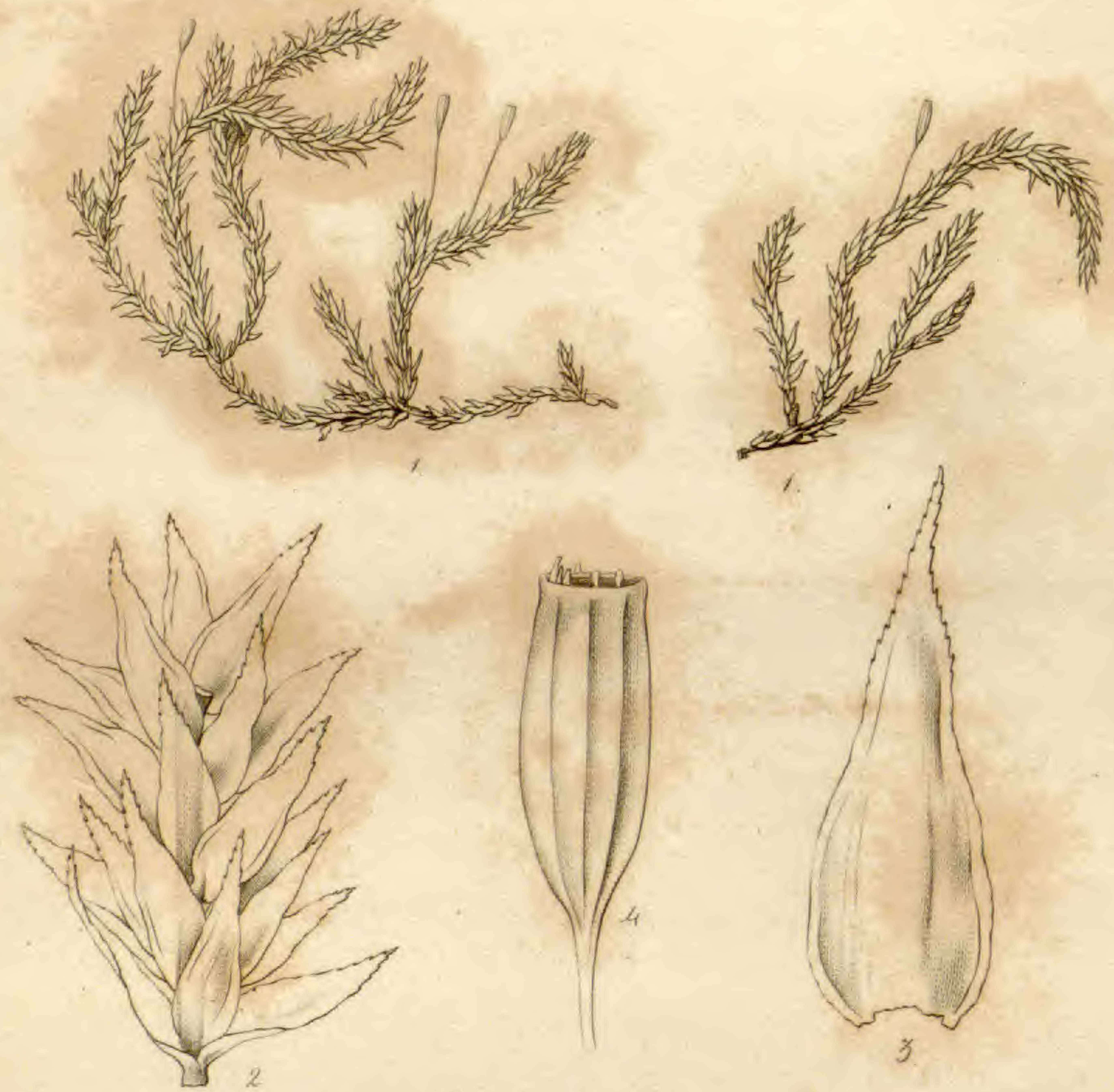

Sestuen scumorides. 


\section{LESKEA SCIUROIDES.}

Leskea caule decumbente, ramis compressis curvatis, foliis undique insertis patulis ovato-acuminatis serrulatis substriatis enervibus, seta breviuscula, capsula oblonga erecta sulcata, (TAB. CLXXV.)

HAB. In Insula Van Diemen. D. R. Brown.

Caules tri-quadriunciales, inferne procumbentes, apicibus ramisque insigniter curvatis, compressis. Folia undique inserta, flavo-viridia, nitida, patula, ovato-acuminata, paululum flexuosa, mollia, submembranacea, margine apicem versus præcipue serrata, enervia sed paululum striata. Seta brevis, vix unciam longa, erecta. Capsula erecta, oblonga, pallide fusca, longitudinaliter sulcata. Peristomium imperfectum. Calyplra operculumque desunt.

This moss, without having any one particularly striking feature, is not likely, that I know of, to be confounded with any other. The fruit is small for the size of the plant, and the capsule is, like that of Leskea sulcata, strongly furrowed. The teeth are very much injured, so that it is by habit alone that I guess at its genus.

Fig. 1, plant, nat. size. Fig. 2, portion of a stem with leaves, Fig. 3, single leaf. Fig. 4, capsule, - magn. 


\section{BARTRAMIA AFFINIS.}

Bartramia caule elongato ramoso, foliis erecto-patentibus ovatis anguste attenuatis subintegerrimis strictis, setis longiusculis, capsulis sphæricis arcuato-cernuis. ( $\mathrm{T}_{\mathbf{A B}}$. CLXXVI.)

Hab. In Insula Van Diemen. D. R. Brown.

Caules 3-4-unciales, graciles, erecti, flexuosi, ramosi, ramis dichotomis, inferne ferrugineo-tomentosi. Folia fusco-lutea, undique imbricata, erecto-patentia, ovata, anguste tenuiter acuminata, vix sub summo lente serrata, margine incrassata, nervo ultra apicem excurrente, instructa. Perigonialia late ovata, acuta, enervia, inferne gibbosa, aurantiaca. Seta breviuscula, flexuosa. Capsula sphærica, sulcata, arcuato-cernua.

The first aspect of this Bartramia is very similar indeed to that of B. Menziesii. The leaves, however, are shorter, much broader and more patent, but far less serrated, if they be serrated at all; and, if I have not mistaken a curvature of the fruit-stalk in consequence of drying, for a true inflexion, causing a nodding capsule, here is an abundantly distinguishing mark, were any other needful. In those setæ which I have immersed in water for a considerable length of time, the curvature was even more decided than when in a dry state.

Fig. 1, male plant, and fig. 2, 2, female plants, nat. size. Fig. 3, branch of a male plant. Fig. 4, perigonial leaf. Fig. 5, anthers and filaments. Fig. 6, leaf. Fig. 7, apex of ditto.magn. 


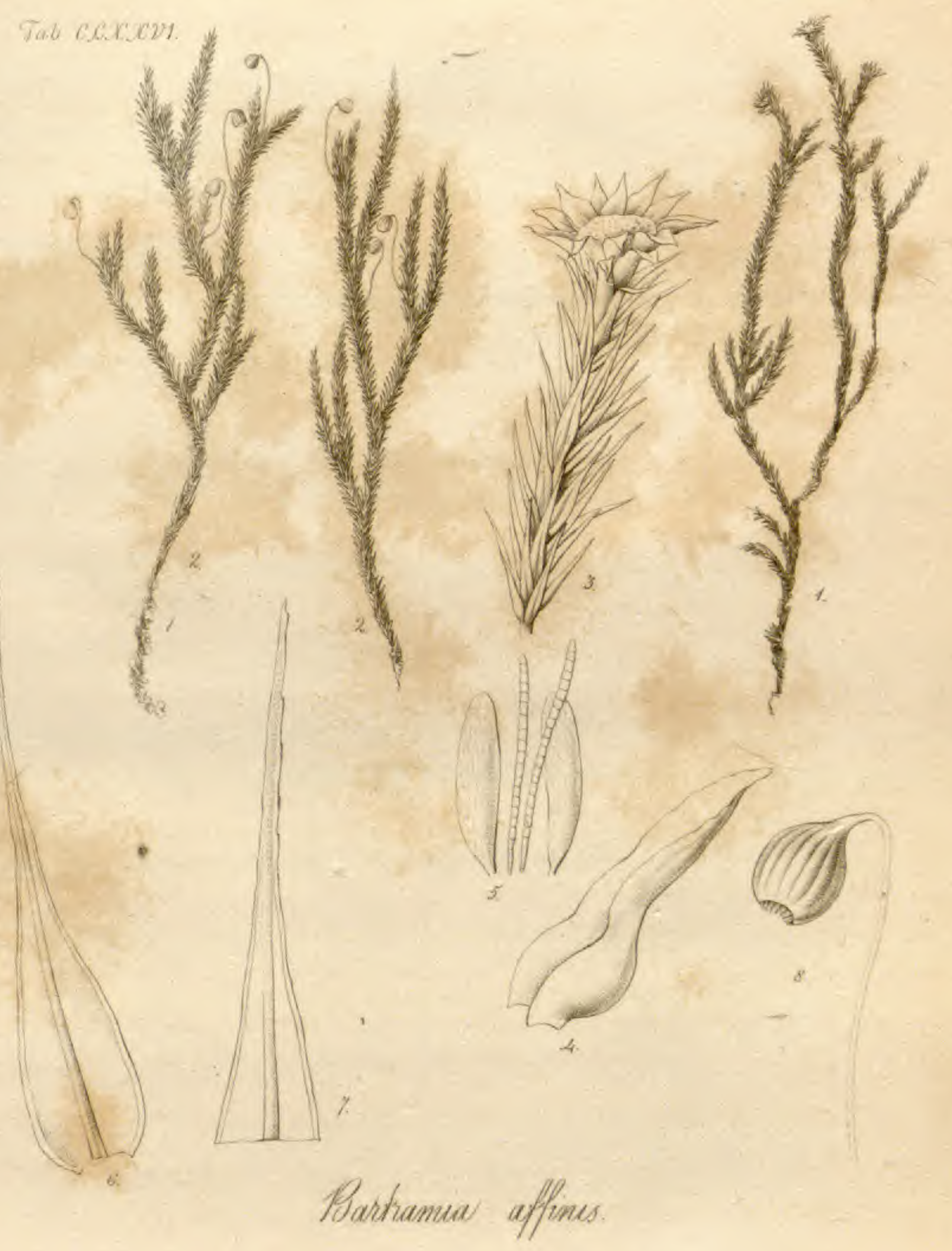




\section{A P P E N D I X}

Containing Specific Characters of the Mosses described in this Work, systematically arranged, with Corrections and additional Remarks.

\section{MUSCI CALYPTRATI.}

\section{Div. I. Stomate edentulo.}

\section{Gen. I. PHASCUM.}

Seta terminalis. Operculum adnatum. Calyptra dimidiata (brevis, fugax).

1. P. nervosum; caule subsimplice breviusculo, foliis elliptico-lanceolatis crassinervibus, superioribus longe acuminatis, seta subnulla, capsula immersa ovato-globosa acuminulata. (ТАв. CV.)

HAB. Promontorio Capitis Bonæ Spei. D. Menzies, 1791.

\section{Gen. II. VOITIA.}

Seta terminalis. Operculum adratum. Capsula cum pedunculo (seta) decidua. (Calyptra magna, persistens.) Hornsch.

1. $V$. nivalis. (ТАB. CXCVII.)

Voitia nivalis. Hornsch. in Comment, de Voit. et Systyl, p. 5. t. 1. Id. in Bot. Zeitung, no. vi. p. 83.

$\mathrm{H}_{\triangle B}$. In summis montibus Carinthiæ, ad limites extremos nivis æternæ, ubi in societate Splachni urceolati placentas stercoris vaccini vetustas siccas cæspitibus læte virentibus obtegit. D. Prof. Hornschuch.

\section{Gen. III. GYMNOSTOMUM.}

Seta terminalis. Capsula ore nudo. Calyptra dimidiata.

* Capsula ore extus annulo elastico cincta.

1. G. julaceum; caule erecto filiformi subsimplice, foliis arcte imbricatis appressis ovatis serrulatis convolutis, nervo crasso, perichætialibus majoribus oblongis acuminatis, seta longa, capsula oblonga ovata, operculo subulato. (TAB. XLII.)

$\mathrm{H}_{\mathrm{AB}}$. In crepidinibus montis ignivomi Rucu-Pichinca prope Tablahuma, regione frigida, super basaltam altitudine 2340 hexapod. (Regni Quitensi.) Humboldt et Bonpland. 
2. G. involutum; caule elongato subramoso, foliis ovato-lanceolatis margine insigniter involutis, nervo ad apicem attingente, seta elongata, capsula anguste cylindracea, operculo subulato. (TAB. CLIV.) HaB. In Nepal. Hon. D. Gardner.

$$
\text { * Capsula ore membrana horizontali clausa. }
$$

3. G. xanthocarpum; caule densissime cæspitoso fastigiatim ramoso, foliis patentibus lineari-lanceolatis, seta longiuscula, capsula ovatosphærica, operculo longirostro curvato. (T'AB. CLIII.)

HАв. In Nepal. Hon. D. Gardner.

4. G. quadratum; caule elongato vage ramoso, foliis patentibus subu latis flexuosis rigidis serrulatis, seta longa flexuosa, capsula quadrata sulcata. (ТАB. CXXXII. sub nom. Bartramice quadrate.)

$\mathrm{H}_{\mathrm{AB}}$. In saxis humectatis umbrosis, ad scaturigines, in acumine montis altissimi Post-berg dicti, prope pagum Georgii in regione Anteniqualand, C. B. S.-rara. D. Burchell.

For remarles on this speeies see G. capense, t. 165 .

5. G. capense; caule ramoso stolonifero, foliis undique vergentibus secundisque lanceolatis longe acuminatis subserratis, seta elongata, capsula sphærica striata, operculo conico-acuto. (TAB, CLXV.)

HАв. In Monte Tabulari, Promont. Bonæ Spei. D. Brown.

*** Capsula ore, intus, membrana annulari plana instructo. товтомим $\mathrm{Br}$.)

6. G. Menziesii; caule subsimplice, foliis oblongo-ovatis apice denticulatis nervosis piliferis, capsula oblongo-clavata subrecurva horizontaliter inclinata, operculo conico, rostro brevi obliquo. (TAв.VI.)

Leptostomum Menziesii. Brown in Linn. Trans. v. x. p. 321.

Haв. Staten Land, prope Cape Horn. D. Menzies, 1787.

7. G. inclinans; caule cæespitoso subrimplice, foliis ovato-oblongis obtusis integerrimis nervosis piliferis, capsula ovato-oblonga horizontaliter inclinata. (TAB. CLXVIII.)

Leptostomum inclinans. Brown in Linn. Trans, v, x, p. 320.

$H_{\mathrm{AB}}$. Rupes et saxa ad latus orientale prope summitatem Montis Tabularis, lat. austr. $43^{\circ}$, elevatione supra mare $3000 \mathrm{ad} 3,500$ ped. Insula Van Diemen. D. Brown.

8. G. gracile; caule cæspitoso subramoso, foliis ovato-lanceolatis integerrimis nervosis longe piliferis, capsula oblongo-cylindracea pendula, operculo hemisphærico mutico. (T $\mathrm{T}_{\mathrm{AB}}$. XXII.)

Leptostomum gracile. Brown in Linn. Trans. v. x. p. 321.

HAB. In sinu Dusky Bay dicto, in Nova Zeelandia. D. Menzies, 1791.

9. G. Leptostomum; caule cæspitoso subsimplice, foliis oblongis obtusissimis integerrimis nervosis pilo simplice terminatis, capsula ovata erecta. (TAB. CLXIX.)

Leptostomum erectum. Brown in Linn. Trans. v. x. p. 320.

HAB. Novæ Hollandiæ ora orientalis, extra tropicum, in rupes prope fluviorum ripas in regione montana, ad fluvios Hawkesbury et Grose. D. R. Brown. 


\section{Gen. IV. DREPANOPHYLLUM.}

(For the very imperfect character of this Genus, see Description to TAB. CXLV.)

1. D. fulvum. (T $\mathrm{T}_{\mathrm{AB}}$ LXXXII. sub nom. Dicrani falcifolii et $\mathrm{T}_{\mathrm{AB}}$. CXLV.) Fissidens falcifolius. Schwaegr. Suppl. v. ii. p. 9 .

$\mathrm{H}_{\mathrm{AB}}$. In sylvis Guyannæ Gallicæ. D. Prof. Richard.

The stations for this curious plant, copied from Schwaegrichen, under Dicranum falcifolium t. 82, are probably not correct.

\section{Gen. V. ANICTANGIUM.}

Seta terminalis. Capsula ore nudo. Calyptra mitriformis.

1. A. repens; caule repente ramoso, ramis erectis clavatis, foliis ovatorotundatis reticulatis acuminulatis enervibus, perichætialibus longe acuminatis diaphanis, seta subnulla, capsula cyathiformi, operculo conico depresso. (TАв. CVI.)

НАв. In plaga occidentali Novæ Hollandiæ. D. Menzies, 1791.

2. A. torquatum; caule repente subtus tomentoso stipulatoque, foliis distichis ligulatis nervosis apice involutis, perichætialibus stipulisque lanceolatis strictis, capsula immersa. (TAB. XLI.)

$H_{A B}$. Ad ripam fluminis Amazonum in umbrosis calidis provinciæ Jaen de Bracamoros, prope Tomependam. Humboldt et Bonpland.

\section{Gen. VI. HEDWIGIA.}

Seta lateralis. Capsula ore nudo. Calyptra dimidiata.

1. H. Humboldtii; caule erecto pinnatim ramoso, foliis undique imbricatis obovatis concavis enervibus piliferis integerrimis, capsula globosa sulcata, operculo subulato curvato. ( $\mathrm{T}_{\mathrm{AB}}$. CXXXVII.)

HAB. In monte Quindiu, locis frigidis, altit, 1580 hexapod. Humboldt et Bonpland. Insulis australibus. D. G. Forster, in Herb. Lambert.

2. H. Hornschuchiana; caule cæspitoso elongato subramoso, foliis longe subulatis flexuosis patentibus carinatis integerrimis, nervo lato, seta brevi, capsula globosa, operculo oblique rostrato. (TAB. CIII.)

Anictangium Hornschuchianum. Funck. Hornsch. in Bot. Zeitung. no. vi. p. 83 .

$\mathrm{H}_{\mathrm{AB}}$. Ad rupes madidas prope Heiligenblul in alpibus Carinthiacis superioribus. D. Prof. Hornschuch.

3. H. Schmidtii; caule procumbente ramoso, foliis undique imbricatis erectis ovato-acuminatis striatis integerrimis enervibus, capsula globosa, operculo subulato. ( $\mathrm{T}_{\mathrm{AB}}, \mathrm{CLXX}$.)

HAB. In sylvis umbrosis prope Laguna, truncos et ramos arbustorum vestiens; Teneriffæ. D. Prof. Schmidt, 1815.

4. H. secunda; caule erecto ramoso, ramis subpinnatis, foliis secundis late ovatis acuminulatis marginatis striatis enervibus apice serrulatis, capsula ovato-cylindracea, operculo subulato. 
HAB. In regni Mexicani montosis apricis, juxta Toluccam, ad radices montis perpetua nive obtecti, regione frigida, altitudine 1640 hexapodarum. Humboldt et Bonpland.

\section{Gen. VII. LYELLIA.}

Capsula hinc plana, inde convexa. Stoma clausum efiphragmati (crasso depresso) cujus discus circularis a limbo (latiori) persistente secedens, cum columella remanenti inclusa cohæret. Calyptra cucullata, apice pilosa. $\mathrm{Br}$.

1. L. crispa. (TAB, CLXI.)

Lyellia crispa. Brown in Linn. Trans. v. xii, p. 562.

HАв. Nepal, Indiæ orientalis. Hon. D. Gardner.

\section{Gen. VIII. DAWSONIA.}

Capsula hine plana, inde convexa. Perist . penicillatum, ciliis numerosissimis capillaribus rectis æqualibus e capsulæ parietibus columellæque ortis. Calyptra ext. e villis implexis; int. apice scabra. $\mathrm{Br}$.

1. D. polytrichioides. (TAв. CLXII.)

Dawsonia polytrichoides. Brown in Linn. Trans. v. x. p. 316.

НАв. Ad ripas subumbrosas rivulorum, ad radices montium, in vicinitate Portus Jackson, Novæ Hollandiæ, D. Brown.

\section{Div. II. Stomate dentibus instructo.}

* Peristomio simplice.

\section{Gen. IX. POLYTRICHUM.}

Peristomizm simplex, e dentibus 32 vel 64 æquidistantibus incurvis, apicibus membrana horizontali unitis. Calyptra dimidiata.

\section{* Calyptra villosa. (Рolytrichum verum.)}

1. P.giganteum; caule valde elongato subfastigiatim ramoso, foliis erectis lineari-subulatis rigidis, margine apicem versus parum involutis dorsoque scabris, setis numerosis, capsula ovato-cylindracea, operculo rostrato. (TAB. LXV.)

НАв. In devexo montis Quindiu, ad radices Ceroxyli andicola, in temperatis usque ad altitudinem 1450 hexapodarum. Humboldt et Bonpland.

2. P. longisetum; caule elongato subsimplice, foliis patentibus lanceolato-subulatis planis rigidis integerrimis, nervo latissimo, seta longissima, capsula ovato-tetragona, operculo rostro subæque longo. (TAB. LXVI.)

IfAB. In monte Quindiu, regione temperata. (Andes de Cundinamara.) Humboldt et Bonpland. Peru. Ruiz et Pavon. 
Calyptra glabra. (Catharinea Auct.)

3. P. lavigatum; caule simplice, foliis arcte imbricatis ovatis concavis integerrimis, nervo crasso lamellato, capsula late ovata cernua. (TAB. LXXXI.)

Polytrichum lævigatum. Wahl. Fl. Lapp. p. 349. t. 22.

$\mathrm{H}_{\mathrm{AB}}$. In nuda arena riparia aprica fluminis Muconio, prope pagum Muconio superiorem et Ketkes-servando, Lapponiæ sylvaticæ Tornensis, frequentissime. Wahlenberg. Locis sterilibus Islandiæ, 1809.

4. P. angustatum; caule brevi, foliis lineari-lanceolatis undulatis, siccitate crispatis, versus apicem dorso margineque denticulatis, nervo lato lamellato, capsula erecta curvula, operculo brevi-subulato. ( $\mathrm{T}_{\mathrm{AB}}, \mathrm{L}$.)

P. angustatum. Brid. Hist. Musc, Suppl, v, i. p. 78. Schwaegr. Sp. Musc, v. ii. p. 331.

HAB. Prope Boston in America septentrionali. D. Boott. (In Carolinæ humosis, $\mathrm{Cl}$. Bosc ; In Pennsylvania, Muhlenberg; In Neomarchia lectum Ill. Schultz. dedere.) Schwaegr. loc. cit.

5. P. tenuirostre; caule brevi simplice, foliis patentibus lanceolatis obtusis subflexuosis canaliculatis integerrimis, nervo subangusto lamellato, capsula ovata, operculo longe-subulato. (TАв. LXXV.)

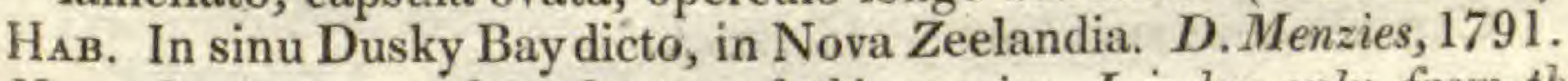

Never having seen the calyptra of this species, I judge only from the habit that it belongs to this division.

\section{Gen. X. OCTOBLEPHARUM.}

Sela terminalis. Peristomium simplex, e dentibus 8 geminatis.

1. O. serratum; caule erecto ramoso, foliis erecto-patentibus ovatis serratis cuspidatis, capsula pyriformi, operculo hemisphærico apiculato, calyptra mitriformi longe pilosa. (ТАB. CXXXVI.)

Octoblepharum serratum. Brid. Musc. Suppl, v. i. p. 86.

Orthodon. Bory de St. Vincent (fide Beauv.).

Bryum orthodontum. Beauv. Prodr. d'AEtheog. p. 48.

Splachnum squarrosum. Hook. in Linn. Trans. v. x. p. 308, t.26.f.2.

$\mathrm{H}_{\mathrm{AB}}$. In Nepal abunde legerunt D. Buchanan, M.D. et Hon. D. Gardner. In insula Borboniæ ad terram humidam prope truncos aversos. Bory de St. Vincent.

\section{Gen. XI. FABRONIA.}

Seta lateralis. Peristomium simplex, e dentibus 8 geminatis.

1. F. polycarpa ; caule repente ramoso, foliis laxis ovato-acuminatis reticulatis integerrimis, nervo brevi, capsula turbinata, operculo conico. (TAB. III.)

$\mathrm{H}_{\mathrm{AB}}$. In umbroșis montis Quindiu, ad radices Quercus Granatensis juxta la Quebrada de Toche, altitudine 1050 hexapodarum. Humboldt et Bonpland.

2. F. australis; caule repente ramoso, foliis erectis lanceolatis longe acuminatis reticulatis subserratis, nervo brevi, capsula elliptica, operculo planiusculo. (TAB. CLX.) 
Fabroniæ spec. Menz. MSS.

HАB. In sinu King George dicto, Nova Hollandia. D. Menzies,

\section{Gen. XII. SPLACHNUM.}

Seta terminalis. Peristomium simplex, e dentibus 8 geminatis. Capsula apophysata. Calyptra mitriformis integra.

1. S. scabrisetum; foliis lingulatis obtusissimis, nervo ante apicem evanescente, capsula cylindracea apophysi vix latiore, seta scabra. (TAB. XXXII.)

$\mathrm{H}_{\mathrm{AB}}$. In umbrosis temperatis Gonzanaman inter et Lucarque (Prov. Jaen de Bracamoros), altitudine 1060 hexapod. Humboldt et Bonpland.

2. S. Octoblepharum; foliis oblongo-obovatis integerrimis superioribus piliferis, capsula apophysique cylindraceis, dentibus 8 subintegris. (TAB. CLXVII.)

$\mathrm{H}_{\mathrm{AB}}$. In truncis arborum emortuarum in Insula Van Diemen. D. Brown.

\section{Gen. XIII. SYSTYLIUM.}

Peristomium simplex, e dentibus 16 parium brevibus, basi conjunctis. Operculum cum columella connatum, persistens. (Capsula cum apophysi.) Hornsch.

\section{S. splachnoides. (TАв. XCVIII.)}

Systylium splachnoides. Hornsch. in Comment, de Voit. et Systyl.p.14. t. 2. Id. in Bot. Zeitung. no. vi. p. 87.

$\mathrm{H}_{\mathrm{AB}}$. Ad rupem micaceo-schistosam, unico tantum loco, in alpibus Carinthiæ superioris, D. Prof. Hornschuch.

\section{Gen. XIV. TAYLORIA.}

Peristomium simplex, e dentibus 32 longissimis, tortuosis, per paria approximatis. Capsula apophysata.

1. T. splachnoides. (TAB. CLXXIII.)

Tayloria splachnoides. Hook, in Journ. of Science and the Arts, no. iii. p. 144.

Hookeria splachnoides. Schwaegr. Suppl. v. ii. p. 340. t. 100.

Н Schmidt. Rupibus madidis in monte Grimsel dicto et prope Glacier du Rhône, Helvetiæ, altitud. 5000 ped. 1814.-In Tyroli australi. Lehmann. In summis alpibus Carinthiacis. D. Prof. Hornschuch. Helvetia. Schleicher.

\section{Gen. XV. TORTULA:}

Seta terminalis. Peristomium simplex, e dentibus 32 filiformibus tortis, basi in tubum magis minusve unitis. Calyptra dimidiata.

1. $T$, membranifolia; subacaulis, foliis late ovatis membranaceis (albis) longe piliferis, nervo (viridi) latissimo, capsula oblonga, operculo rostrato. (TАB, XXVI.) 
НАв. Sepibus lapidibusque regionis aridæ Orotavæ, Teneriffæ. Prof. C. Schmidt, 1815.

2. $T$. pilifera; caule elongato valde ramoso, foliis lanceolatis margine revolutis, nervo in pilum longum desinente, perichætialibus vaginantibus, capsula cylindracea, operculo subulato. ( $\mathrm{T}_{\mathrm{AB}} . \mathrm{XII}$.)

HAB. Ex Java a Dicksono recepi.

3. T. flexuosa; caule elongato ramoso, foliis lanceolato-linearibus carinatis nervo excurrente, perichætialibus longissimis vaginantibus, capsula cylindracea, operculo longe subulato. (TAB. CXXV.)

НАв. Ad Promontorium Bonæ Spei. D. Menzies, 1791.

4. T. recurvata; caule subnullo, foliis erecto-patentibus lanceolatis acutis marginibus superne recurvis, nervo crasso in mucronem brevem excurrente, seta elongata, capsula cylindracea, operculo conico-cylindraceo. (TAB. CXXX.)

НАB. In territorio coloniali Capitis Bonæ Spei, in regione Roggeveld, inter Jakhals Fonteyn et Kuylenberg:-terrestris, in campis aridis rara, D. Burchell.

5. T.indica; caule breviusculo subramoso, foliis lineari-oblongis erectis subapiculatis siccitate crispatis, capsula oblonga, operculo acuminato. (TAB. CXXXV.)

Trichostomum indicum. Willd. in Bot. Mag. v. iv. p. 7. t. 1. (fide Schwaegr.) Schwaegr, Suppl. v. i. p.242. t. 36.

НАв. In India orientali. Röttler. In muris Horti Botanici Calcuttæ, Indiæ orientalis. Gul. Wallich, M.D.

\section{Gen, 16. WEISSIA.}

Seta terminalis. Peristomium simplex, e dentibus 16 integris æquidistantibus. Calyptra dimidiata.

1. W. ciliata; foliis lingulatis longissime ciliatis. (TAB. CLXXI.)

НАв. Ex insula Ternatæ accepit D. Dicksonus.

2. W. pomiformis; caule cæspitoso elongato subsimplice, foliis linearilanceolatis suberectis, perichæetialibus subulatis convolutis, seta paululum exserta, capsula sphærica, operculo curvirostrato. (ТАB. CXXXI.)

НАв. In rupibus humidis soli et tempestati expositis, montium altissimorum ad locum Mountain Station dictum, rivulo Krombeks vicinum, et alibi in jurisdictione Zwellendam, territ. C. B. S., hic illic obvia, sed raro cum fructificatione invenienda. D. Burchell.

3. W. Mielichoferi; caule dense cæspitoso elongato ramoso, foliis anguste lanceolatis subserrulatis rigidis, nervo crasso, seta elongata, capsula erecta pyriformi, operculo conico. (TAB. CI.)

Weissia Mielichoferiana Funck. Hornsch, in Bot. Zeitung. no, vi. p. 86 .

НАB. In valle Grosarl in alpibus Salisburgensibus legit mihique benevole communicavit D. Prof. Hornschuch.

4. W. elongata; caule densissime cæspitoso elongato ramoso, foliis arcte imbricatis lanceolato-ovatis obtusis reticulatis integerrimis, 
nervo sub summo apice evanescente, seta flexuosa arcuata, capsula ovata, operculo conico. ( $\mathrm{T}_{\mathrm{AB}}$. CII.)

Weissia elongata. Hoppe et Hornsch. MSS. (Hornsch. in lit.)

Weissia Mielichoferiana $\beta$ elongata. Hornsch. in Bot. Zeitung. no. vi. p. 87.

HAB. In valle Grosarl in alpibus Salisburgensibus, D. Prof. Hornschuch.

Dr. Hornschuch has, very much to my surprise, in the work above quoted made this a variety of the preceding moss W. Mielichoferi; though to me the whole habit of the plant, as well as the form of the capsule and texture of the leaves, appear different. The greatest deference is, nevertheless, due to the opinions of so acute an observer; and he has moreover had the opportunity of studying the individuals on their native alps.

5. W. Martiana; caule densissime cæspitoso elongato subramoso, foliis lanceolato-subulatis patentibus siccitate crispatis, seta breviuscula curvata, capsula globosa sulcata. (TAB. CIV.)

Weissia Martiana. Hoppe et Hornsch. MSS. Hornschuch in Bot. Zeitung. no. vi. p. 85 .

Нав. In alpibus Tyrolensibus. D. Prof. Hornschuch.

\section{Gen. XVII. CALYMPERES.}

Seta terminalis. Peristomium simplex, e membrana spongiosa horizontali totum os tegente, demum medio in dentibus 16 brevibus fissa. Calyptra magna, mitriformis, capsulam involvens, demum lateraliter fissa.

1. C. Gardneri; caule breviusculo, foliis linearibus marginibus incurvis serratis, calyptra lævi. (TAB. CXLVI.)

НАB. In Nepal, arboribus. Hon. D. Gardner.

\section{Gen. XVIII. PTEROGONIUM.}

Seta lateralis. Peristomium simplex, e dentibus 16 integris æquidistantibus. Calyptra dimidiata.

1. Pt. pulchellum; caule repente ramoso, foliis undique laxis lanceolato-acuminatis subintegerrimis enervibus, capsula ovato-elliptica, operculo rostrato. (ТА

Han. In umbrosis montosis Quindiu, locis altioribus, altitudine 1070 hexapodarum, prope el Moral, regno Novo-Granatensi. Humboldt et Bonpland.

2. Pt. flavescens; caule repente, ramis pinnatis compressis, foliis undique imbricatis erectis lanceolato-acuminatis planiusculis striatis enervibus, seta longa, capsula cylindracea, operculo rostrato. ( $\mathrm{T}_{\mathrm{AB}}$. CLV.)

НАв. In Nepal. Hon. D. Gardner.

3. Pt. aureum; caule repente, ramis erectis, foliis undique imbricatis erecto-patentibus ovato-acuminatis concavis, margine recurvis ener- 
vibus, seta longa, capsula oblonga erecta, operculo conico-rostrato. ( $\mathrm{T}_{\mathrm{AB}}, \mathrm{CXLVII}$.)

НАв. In Nepal, arboribus, legit Hon. D. Gardner.

4. Pt.myurum; caule (fructifero) suberecto pinnatim ramoso, foliis undique imbricatis erectis ovatis valde concavis enervibus integerrimis, seta elongata, capsula oblonga, erecta, operculo acuminato. (TAB. CXLVIII.)

Нав. In Nepal. Hon, D. Gardner.

\section{Gen. XIX. GRIMMIA.}

Seta terminalis. Peristomium simplex e dentibus 16 integris ve] perforatis (rarissime fissis) æquidistantibus. Calyptra mitriformis.

\section{* Capsula immersa.}

1. Gr.fontinaloides; caule elongato ramoso fluitante, foliis oblongoovatis acutis serratis, capsula ovata immersa, operculo plano-mammillato. (TАB. II.)

$\mathrm{H}_{\triangle \mathrm{B}}$. In ripa fluminis Brinosi inter Atures et San Fernando, in arboribus quarum radices aquis obtectæ sunt. Barba de Palo Hispanis nuncupatur. Humboldt et Bonpland.

\section{* Capsula exserta.}

2. Gr. longirostris; caule erecto cæespitoso, foliis undique erecto-patentibus lanceolatis longe acuminatis incanis, seta exserta recta, capsula ovata, operculo longe rostrato. (T $\mathrm{T}_{\mathrm{AB}}$. LXII.)

$\mathrm{H}_{\mathrm{AB}}$. Locis scopulosis, apricis, in declivitate montis Chimborazo, altit. 2380 hexapod. super porphyrite (regnum Quitense). Humboldt et Bonpland.

3. Gr. fusco-lutea; caule erecto cæspitoso, foliis undique erectopatentibus lanceolatis longe acuminatis incanis, seta arcuata, capsula ovata lævi, operculo hemisphærico. (TAB. LXIII.)

НАв. In frigidis Tobeccæ et Islahuacæ, altitudine 1330 hexapod. (regnum Mexicanum). Humboldt et Bonpland.

4. Gr. campestris; caule erecto cæspitoso ramoso, foliis undique erecto-patentibus late ovatis longe acuminatis incanis, seta exserta recta, capsula ovata, operculo brevi-rostrato. (TAB. CXXIX.)

Grimmia campestris. Burchell MSS.

$\mathrm{H}_{A B}$. In territorio coloniali Capitis Bonæ Spei, in regione Roggeveld, inter Jakhals Fonteyn et Kuylenberg ; - terrestris, in campis aridis parce. D. Burchell.

5. Gr. atrata; caule brevi subramoso, foliis erecto-patentibus lancealato-subulatis, apicibus obtusiusculis concoloribus, nervo crasso, seta exserta, capsula oblongo-ovata, operculo conico. (TAB. C.)

Grimmia atrata. Hoppe et Hornsch. MSS. Hornsch. in Bot. Zeitung. no. vi. p. 85 .

$\mathrm{HAB}_{\mathrm{AB}}$. Ad rupes in valle Grosarl in alpibus Salisburgensibus legit D. Prof. Hornschuch. 


\section{Gen. XX. DIDYMODON.}

Seta terminalis. Peristomium simplex e dentibus 16 vel 32 per paria approximatis vel ad basin unitis. Calyptra dimidiata.

1. D. gracile; caule dense cæspitoso elongato, foliis lanceolato-subulatis pilo longo colorato terminatis, capsula erecta cylindracea, operculo subulato, calyptra ciliata. (TAB. V.)

HAB. In monte Quindiu, regione temperata, Andes de Cundinamara. Humboldt et Bonpland.

2. D. squarrosum; caule elongato flexuoso ramoso, foliis undique patentibus squarrosis longe lanceolatis flexuosis carinatis serratis, seta elongata, capsula cylindracea, operculo longe subulato. (TAB. CL.)

НАв. In Nepal. Hon. D. Gardner.

3. D.? splachnifolium; caule subelongato simplice, foliis lingulatis reticulatis integerrimis, nervo sub summum apicem evanescente, seta breviuscula, capsula cylindracea, operculo conico. (TАB.LXXVI.) Weissia obtusa. Brid. Musc. Suppl. v. i. p. 118.

НАв. In insulis Antillarum. Prof. Richard. E Sancti Dominici insula communicavit D. Coulon. In Hispaniola, ubi Poiteau legit et communicavit (in Bridel).

Bridel's character of his Weissia obtusa is too excellent to allow me for a moment to doubt of its being the same as my D.? splachnifolium, " trunco erecto simplice longiusculo, foliis sparsis ovatis obtusis pellucidis, capsula erecta oblonga, operculo subconico brevi." In a subsequent publication, too, he adds, it is found " in omnibus Antillis. Richard." Of the Genus, however, 1 should add, he speals with doubt: for he says, "Peristomatis dentes, quantum in statu valde læso cernere est, erectiusculi, crocei, sedecim numero et forte geminati, tuncque plantula nostra Swarzia vel Didymodon esset."

\section{Gen. XXI, DICRANUM.}

Sela terminalis. Peristomium simplex e dentibus 16 bifidis; Calyptra dimidiata.

1. D. fragile; caule elongato ramoso, foliis subsecundis subulatosetaceis serratis siccitate subflexuosis, perichætialibus basi vaginatis, capsula erecta cylindracea. (TAB. CXXIV.)

НАв. In Nepal legit Hon. D. Gardner, et J. Bantes Baroneto communicavit Gul. Wallich, M.D.

2. D. concolor; caule elongato ramoso, foliis undique vergentibus e basi anguste lanceolata longissime subulato-setaceis subintegerrimis, nervo latissimo, seta flexuosa, capsula ovata striata strumosa, calyptra fimbriata. (TАB. CXXXVIII.)

НАв. In alto de Aranda, locis frigidis, prope Pasto (́regnum Novum Granatense) altit. 1560 hexapod. Humboldt et Bonpland. 
3. D. longisetum; caule subelongato simpliciusculo, foliis falcatosecundis e basi late ovata longe tenuiterque subulato-setaceis, seta longa, capsula erecta oblonga striata, struma nulla, operculo longe subulato. (ТАв. CXXXIX.).

НАB. In temperatis regni Novi Granatensis, in sylvis prope Fusagasaga, altit. 1030 hexap, atque in apricis frigidis montis Chimborazo, altit, 2430 hexap. Humboldt et Bonpland.

4. D. densum; caule simpliciusculo, foliis lanceolato-subulatis integerrimis, nervo tenui, capsula ovata inclinata lævi absque struma, operculo longe rostrato curvato. (TAB. CXL.)

$\mathrm{H}_{\mathrm{AB}}$. In crepidinibus montis Quindiu, regione temperata. Humboldt et Bonpland.

5. D. vaginatum; caule elongato ramoso, foliis laxis e basi longe vaginante subulatis vix apice serratis, nervo excurrente, capsula inclinata ovata absque struma, operculo longe subulato. (T $\mathrm{T}_{\mathrm{B}}$. CXLI.)

Нав. In convallibus Andium Granatensium inter Almaguar et Pasto, altit. 1200-1500 hexapod. Humboldt et Bonpland.

6. D. flexifolium; caule subnullo, foliis longissime subulatis flexuosis, perichætialibus longe vaginantibus, seta mediocri, capsula oblonga erecta lævi absque struma, operculo conico-acuminato. (TAB. CXLIV.)

Нав. In Capite Bonæ Spei. D. Menzies, 1791.

7. D. fulvum; caule elongato erecto ramoso, foliis undique insertis lanceolato-subulatis integerrimis concavis flexuosis siccitate crispatis, nervo crasso, perichætialibus vaginantibus aristatis, seta breviuscula, capsula oblonga cylindracea erecta. (TAB, CXLIX.)

HAB. In Nova Scotia. D. Menzies.

\section{Gen. XXII. TRICHOSTOMUM.}

Seta terminalis, Peristomium e dentibus 16 ad basin divisis, vel 32 per paria approximatis. Calyptra mitriformis.

1. Tr. vaginatum; caule erecto ramoso, foliis late lanceolatis lateribus involutis, perichætialibus longe vaginatis, seta elongata, capsula oblonga, operculo subulato. (TAB. LXIV.)

Haв. In insula Otaheite, mare Pacifico, D. Menzies, 1792.

2. $\operatorname{Tr}$. perichatiale; caule erecto ramoso, foliis lanceolatis tenuiter acuminatis, perichætialibus longe vaginatis, seta elongata, capsula oblonga, operculo subulato. (TAB. LXXIII.)

Н Ав. In sinu Dusky Bay dicto, in Nova Zeelandia. D. Menzies, 1791.

Since the publication of the figure of this Moss I have seen more perfect specimens in $\mathrm{Mr}$. Menzies's Herbarium, and ascertained that the operculum is subulate, nearly as long as the capsule. 


\section{Gen. XXIII. LEUCODON.}

Selo lateralis. Peristomium simplex, e dentibus 16 fissis, vel 32 per paria arcte unitis.

1. L. lagurus; caule erecto tomentoso ramoso, foliis imbricatis ovatis concavis acuminulatis enervibus, capsula erecta cylindracea, operculo acuminato. (ТАB. CXXVI.)

Hypnum lagurum. Menzies' MSS.

HaB. In Insula Staten Land dieta, prope Cape Horn. D. Menzies, 1787.

2. L.tomentosus; caule subrepente densissime tomentoso, ramis erectis, foliis undique imbricatis erectis lanceolatis plicatis, basi nervo obsoleto, apice acumine piliformi serrulato, capsulis erectis ovatocylindraceis. (TАB. XXXVII.)

HAB. In sylvis Cinchonæ prope Loxam, regione temperata, altit. 1080 hexapod. Humboldt et Bonpland.

3, L. calycinus; caule repente, ramis erectis simplicibus, foliis ovatolanceolatis concavis lævibus, nervo attingente, perichætialibus setam omnino vaginantibus obtusiusculis enervibus, capsula oblongo-cylindracea curvata strumosa, ore obliquo, operculo subulato basi gibbosa. (TAB. XVII.)

HaB. In sinu Dusky Bay dicto, in Nova Zeelandia. D. Menzies, 1791.

4. L. rugosus; caule repente, ramis erectis simplicibus, foliis ovatolanceolatis transversim rugosis, nervo attingente, perichætialibus setam omnino vaginantibus attenuatis nervosis, capsula cylindracea erectiuscula striata, ore horizontali, operculo subulato. ( $\mathrm{T}_{\mathrm{AB}}, \mathrm{XX}$.) Hав. In "Nova Hollandia." Turn. Herb.

5. L. pallidus; caule procumbente ramoso, foliis ovatis longe acuminatis integerrimis, nervo pellucido attingente, seta longa flexuosa, capsula inclinata, operculo rostrato. (TAB. CLXXII.)

НАв. In Nova Hollandia. A Diclesono et Hobsono receptus.

** Peristomio duplice.

\section{Gen. XXIV. ZYGODON.}

Seta terminalis. Peristomium duplex : ext. e dentibus 16 per paria approximatis: int. e ciliis totidem horizontalibus. $\mathrm{Ca}$ lyptra dimidiata brevis.

1. Z. obtusifolium; foliis obtusis. (TAв. CLIX.)

НАв. In Nepal. Hon. D. Gardner.

\section{Gen. XXV. ORTHOTRICHUM.}

Sela terminalis. Peristomium duplex: ext. e dentibus 16 per paria approximatis: int. e ciliis $8-16$ vel nullis. Calyptra mitriformis.

1. O. prorepens; caule repente, ramis erectis, foliis ovato-attenuatis 
obtusis dorso carinatis, nervo excurrente, seta longiuscula exserta, capsula exacte ovali lævi, calyptra pilosa. (TAB. CXX.)

HAs. In sinu Dusky Bay dicto, in Nova Zeelandia. D. Menzies, 1791.

\section{** Calyptra muda;}

\section{+ Basi quadridentata.}

2. O. rugifolium; caule repente, ramis erectis, folis ellipticis substriatis rugosis, nervo breviter excurrente, seta longiuscula, capsula ovato-oblonga lævi, calyptra campanulata. (TAB. CXXVIII.)

$\mathrm{H}_{\mathrm{AB}}$. Prope Rio Janeiro Americæ meridionalis. D. Swainson.

\section{十† Basi-(calypira) multifida.}

\section{+ Capsula sulcata.}

3. O. longirostrum; caule repente, ramis erectis, foliis lanceolatoacuminatis striatis siccitate tortis, seta longa, capsula ovali-elliptica, ciliis nullis, dentibus 16 vix per paria approximatis. (ТАв. XXV.) HА́в. In sinu Dusky Bay dicto, in Nova Zeelandia. D. Menzies, 1791.

4. O. longifolium; caule repente, ramis erectis, foliis lanceolato-subulatis flexuosis siccitate crispis, seta longa, capsula brevi ovata, ciliis nullis, dentibus 16 per paria unitis. (TAB. XLIV.)

$\mathrm{H}_{\mathrm{AB}}$. Ad radices Bifaria glauce* ${ }^{*}$ altitudine 950 hexapod, regione temperata, in devexis montis Avilæ prope Caraccas. Humboldt et Bonpland.

\section{$\leftarrow+$ Capsula levi.}

5. O. longipes; caule procumbente, ramis erectis, foliis ovato-lanceolatis striatis siccitate tortis, seta longissima, capsula ovali-elliptica, ciliis nullis, dentibus 16 per paria approximatis. ( $\mathrm{T}_{\mathbf{A}}$. XXIV.)

Haв. In sinu Dusky Bay dicto, in Nova Zeelandia. D. Menzies, 1791.

6. O apiculatum; caule repente, ramis erectis, foliis oblongis apiculatis medio canaliculatis siccitate tortis, seta longa, capsula ovatocylindracea. (TAв. XLV.)

Haв. Prope Xalapam in regno Mexicano, regione temperata. Humboldt et Bonpland.

7. O. Swainsoni; caule repente, ramis erectis, foliis ellipticis longitudinaliter plicatis, nervo breviter excurrente, seta longiuscula, capsula ovata. (TAB. CXXVII.)

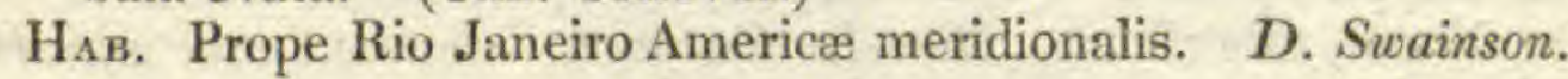

8. O. urceolatum; caule repente, ramis erectis, foliis lanceolatoattenuatis dorso carinatis, nervo attingente, seta sublonge exserta, capsula urceolata. (ТАв. CXXIV.)

$\mathrm{H}_{\mathrm{AB}}$. In insula Sanctæ Helenæ. D. Menzies, 1795.

9. O. gracile; caule erecto elongato ramoso, foliis lanceolato-subulatis flexuosis siccitate tortis, seta breviuscula, capsula ovats ciliis nullis, dentibus 16 per paria approximatis. (TAB. XXVII.)

HAB. In sinu Dusky Bay dicto, in Nova Zeelandia. D. Menzies, 1791.

- Humboldt et Bonpl. Pl .Ẽqunoct. v, ii. p.110. 


\section{Gen. XXVI. SCLOTHEIMIA.}

Seta terminalis. Peristomium duplex : ext. e dentibus 16 revolutis : int. membrana conica plicata, irregulariter fissa.

1. S. sulcata; caule repente, ramis erectis brevibus, foliis linearilanceolatis acuminatis undulatis (siccitate crispis), seta longa, capsula ovata profunde sulcata. (TAB. CLVI.)

HA3. In Nepal. Hon. D. Gardner.

\section{Gen. XXVII. NECKERA Hedw.}

Seta lateralis. Peristomium duplex: ext. e dentibus 16 erectis liberis : int. e ciliis totidem cum externis alternantibus.

$$
\text { * Foliis bifariis. }
$$

1. N. dendroides; caule erecto bipinnatim ramoso, foliis distichis planis apice serratis, basi nervosis, caulinis oblongis, rameis ovatorotundatis, seta brevi exserta, capsula ovato-cylindracea. (TAB. LXIX.)

Нав. In insula Owhyhee. D. Menzies, 1793.

2. N. longirostris; caule erecto bipinnato, ramis attenuatis, foliis subdistichis ovatis acutis serratis, nervo prope medium evanescente, operculo longirostro recto. ( $\mathrm{T}_{\mathrm{AB}} . \mathrm{I}$.)

НАв. Regione temperata, in jugis Andium. Humboldt et Bonpland.

3. N. planifolia; caule erecto pinnato, foliis bifariam imbricatis late ovatis acutis enervibus serrulatis, seta longa exserta, capsula cylindracea, operculo subulato. (TAB. XXIII.)

Neckera planifolia. Hedw. Sp. Musc, t. 48. f. 1-3.

HAB. Insulæ australes. Hedwig. In sinu Dusky Bay dicto. D. Mertzies, 1791.

\section{* Foliis undique insertis. \\ $\uparrow$ Surculis pendulis.}

4. N. fuscescens; caule longissimo filiformi pendulo pinnatim ramoso, foliis lanceolatis acuminatis serrulatis substriatis, nervo ante medium evanescente, seta brevissima, capsula oblonga perichætio immersa, calyptra pilosa. (Tав. CLVII.)

НАв. In Nepal, arboribus. Hon. D. Gardner.

5. N. filamentosa; caule longissimo pendulo pinnatim ramoso, foliis squarrosis ovatis concavis undulatis acuminatis pilo longo flexuose terminatis, nervo paulo ultra medium evanescente, seta mediocri, capsula cylindracea, calyptra mitriformi (?) pilosa. (TAB. CLVIII.)

HAB. In Nepal, arboribus, legit Hon. D. Gardner.

†十 Surculis erectis vel procumbentibus.

6. N. setosa; caule erecto ramoso, foliis confertissimis e lata basi subulato-setaceis nervosis, seta perichætio duplo longiore, capsula oblonga erecta, operculo rostrato. (TAB. VII.)

Anictangium setosum, Hedw, Sp, Musc, p. 43, t. 5 . 
HAB. Insulæe australes. Hedw. In sinu Dusky Bay dicto legit $D$, Menzies, 1791.

7. N. abietina; caule erecto pinnato, foliis undique imbricatis appressis striatis subintegerrimis, caulinis ovato-deltoideis, rameis ovatis, seta exserta, capsula ovato-cylindracea, operculo subulato. (TAB. VII.)

НАв. In plaga occidentali Americæ borealis. D. Menzies, 1792.

8. N. affinis; caule ramoso, ramis pinnatis, foliis undique imbricatis erectis lanceolato-acuminatis longe binervibus, seta perbrevi, capsula erecta cylindracea. (TАв. CXXII.)

Neckera composita, var. $\beta$. Schwaegr. Suppl, v. ii. $p$. 156 ?

HAs. Ex insula Sancti Vincentii a D. Menzies communicata.

9. N. longiseta; caule subpinnatim ramoso, foliis undique imbricatis late ovatis acuminatis enervibus subintegerrimis, seta longa, capsula oblongo-cylindracea, operculo subulato. (TAB. XLIII.)

HaB. Locis umbrosis altis montis Quindiu (Cordillera de los Andes de Cundinamara). Humboldt et Bonpland.

10. N. acuminata; caule erectiusculo ramoso inferne subsimplice, foliis undique imbricatis erectis late ovatis valde concavis acuminatis subintegerrimis, nervo brevi, seta brevi, capsula ovato-oblonga. (TAв. CLI.)

HАв. In Nepal. Hon. D. Gardner.

11. N. crispaitla; caule longissimo procumbente ramoso, ramis pinnatis, foliis falcato-secundis lanceolatis serratis crispatis substriatis, nervo ante apicem evanescente, seta brevi, capsula ovata, operculo rostro curvato. (TÁ, CLHI.)

Hypnum crispatulum. Hook, in Linn. Trans, v. ix. p. 321. t. 28.

HAB, In Nepal. F. Buchanan, M. D. et Hon. D. Gardner.

\section{Gen. XXVIII. BARTRAMIA.}

Seta terminalis. Peristomium duplex: ext. e dentibus 16: int. membrana plicata in laciniis 16 bifidis fissa.

1. B. tomentosa; caule subpinnatim fasciculatimque ramoso, foliis ovato-lanceolatis longe acuminatis serrulatis striatis, nervo attingente, seta longa recta demum laterali, capsula horizontali ovatorotundata sulcata. (TAB. XIX.)

Mnium tomentosum. Swartz. Prodr. p. 139. Fl. Ind.Occ.p.1837. $\mathrm{H}_{\mathrm{AB}}$. Ad latera sylvarum in montibus altissimis Jamaicæ. Swartz.

2. B.pendula; caule subpinnatim fasciculatimque ramoso, foliis ovatolanceolatis longe acuminatis serrulatis striatis, nervo attingente, seta longa recta demum laterali, capsula oblongo-cylindracea sulcata pendula. (TAB. XXI.)

Mnium pendulum. Smith in Linn. Trans, v. vii. p. 262.

HАв. In sinu Dusky Bay dicto, in Nova Zeelandia: D. Menzies, 1791.

3. B. Menziesii; caule elongato ramoso, foliis erectis e basi lanceolata longe subulatis serrulatis strictis, setis longiusculis erectis. (TAB, LXVII.) 
B. Menziesii. Turn in Ann. of Bot. v. i, p. 525. t. 11.f. 4 .

Нав. In plaga oecidentali Americæ septentrionalis. D. Menzies, 1792.

4. B. affinis; caule elongato ramoso, foliis erecto-patentibus ovatis anguste attenuatis subintegerrimis strictis, setis longiusculis, capsulis sphæricis arcuato-cernuis. (TAB. CLXXVI.)

НАв. In insula Van Diemen. D. R. Brown.

5. B. longifolia; caule elongato-ramoso, foliis longissimis subulatis flexuosis minute serratis, setis longiusculis. (TAB. LXVIII.)

$\mathrm{H}_{\Lambda \mathrm{B}}$. In devexis udis frigidis montis Quindiu, super granato, altitudine 1400 hexapod. Humboldt et Bonpland.

\section{Gen. XXIX. BRYUM.}

Seta terminalis. Peristomium duplex : ext. e dentibus 16: int. membrana plicata 16-laciniata, sæpissime ciliis alternantibus. Calyptra dimidiata.

1. Br. bartramioides; caule elongato erecto subsimplice, foliis subulato-setaceis rigidis denticulatis, nervo ad apicem attingente, seta perichætio immersa, capsula late ovata erecta. (TAB. XVIII.)

Haв. In sinu Dusky Bay dicto, in Nova Zeelandia. D. Menzies, 1791.

2. Br. Umbraculum; caule elongato, foliis obovatis acutis marginatis undulatis serratis, nervo excurrente, capsula oblongo-cylindracea pendula. (ТАв, CXXXIII.)

Bryum Umbraculum. Burchell MSS.

НАв. Terrestre, in umbrosis sylvarum densarum regionis Auteniqualand Africæ meridionalis; satis copiose. D. Burchell.

3. Br.demissum; caule perbrevi ramoso, foliis ovatis cuspidato-acuminatis reticulatis, nervo excurrente, seta arcuata, capsula curvatopyriformi pendula. (TАB. XCIX.)

Meesia demissa. Hoppe et Hornsch. MSS. Hornsch. in Bot. Zeitung. no. vii, p. 106.

Timmiæ Nov. Sp. Schmidt MSS.

Bryum curvulum. Schleicher MSS.

НАB. In monte Cenisii supra 7000 pedum elevationem reperi 1814 . Unicum parvulum cæspitem in summo cacumine alpis Wingsfield Opdaliæ Norwegiæ transalpinæ solummodo legit D.Prof. Schmidt. In alpibus Tyrolensibus. D. Prof. Hornschuch. Helvetia. Schleicher.

\section{Gen. XXX. HOOKERIA $S m$.}

Seta lateralis. Peristomium duplex : ext. e dentibus 16: int. membrana 16-laciniata, nunc ciliis alternantibus. Calyptra mitriformis.

\section{* Foliis enervibus.}

1. H. pennata; caule erecto simplice, foliis bifariis verticalibus ovatolanceolatis serratis enervibus, stipulis orbiculatis mucronulatis serratis, seta brevi, capsula ovata erecta. (TAB. CLXIII.)

Hookeria pennata. Smith in Linn. Trans, v. ix. p. 277. 
Pterigophorum pennatum. Brid. Meth. Nov. Musc. p. 149.

Cyathophorum pteridioides. Beauv. Etheog. p. 52.

Leskea pennata. Labill. Nov. Holl, v. ii. p. 206. t. 253. Schwaegr. Suppl. v. ii. p. 160.

Anictangium bulbosum. Hedw. Sp. Musc. p. 43. t. 6.f. 1-5.

НАв. Nova Hollandia. D. Labillardiere. In sinu Dusky Bay dicto, Nova Zeelandia. D. Menzies. Insula Van Diemen. D. R. Brown. ** Foliis uninervíbus.

2. H. quadrifaria; caule erecto subramoso, foliis quadrifariis reticulatis medio uninervibus, lateralibus distichis horizontalibus verticalibus ovatis, intermediis subrotundis erectis appressis, capsula subcylindracea pendula. (TAB. CIX.)

Hookeria quadrifaria. Smith in Linn. Trans. v. ix. p. 277. t. 23. f. 1. $\mathrm{H}_{\mathrm{AB}}$. In sinu Dusky Bay dicto, in Nova Zeelandia. D. Menzies, 1791.

3. $\boldsymbol{H}$. radiculosa; caule repente vage ramoso, ramis compressis subtus denudatis, supra foliosis, foliis ovatis subacuminatis integerrimis, nervo ultra medium evanescente, capsula ovata cernua, operculo rostro curvato, calyptra basi integra. (TAB. LI.)

HAB. Crepidines juxta Caripe, locis scopulosis, temperatis, irriguis, altitudine 480 hexapod. Humboldt et Bonpland. "Orinoco, Herb. Willd." Hornsch. in lit.

\section{*** Foliis binervibus.}

4. H. scabriseta; caule suberecto vage pinnatim ramoso compresso, foliis undique imbricatis late ovatis subacuminulatis binervibus, seta scabra. (TAB. LII.)

$\mathrm{H}_{\mathrm{AB}}$. Crepidines juxta Caripe, locis scopulosis, temperatis, irriguis, altitudine 480 hexapod. Humboldt et Bonpland.

b. H. pallescens; caule suberecto vage ramoso, ramis compressis, foliis undique imbricatis ovatis obtusis minute reticulatis, basi binervibus, seta elongata, capsula subovata, calyptra multifida. (TAB. XXVIII.)

$\mathrm{H}_{\mathrm{AB}}$. Ad ripam fluminis Oronoco prope Esmereldam, locis opacis. Humboldt et Bonpland.

6. H. Langsdorfii; caule elongato repente vage ramoso, foliis distichis compressis ovatis subacuminatis membranaceis submarginatis apice serratis, nervis duobus ante apicem evanescentibus, capsula ovata cernua, operculo hemisphærico rostrato, calyptra basi 6 -fida. (TAB. CXXI.)

$\mathrm{H}_{\mathrm{AB}}$. Prope Rio Janeiro Braziliæ legit $\mathrm{Cl}$. Langsdorf; communicavit D. Swainson.

7. H. pendula; caule decumbente, ramis pinnatis curvatis compressis, foliis undique imbricatis ovatis basi binervibus, capsula nutante, operculo conico rostrato, calyptra carnosa pilosa basi fimbriata. (ТАв. LIII.)

НАв. Regione temperata in jugis Andium. Humboldt et Bonpland.

8. H. falcata; caule procumbente, ramis erectis, foliis falcato-secundis lanceolato-longe-acuminatis serratis binervibus, capsula ovata 
horizontali, operculo subulato, calyptra basi 6-vel 8-fida. (TAB. LIV.)

НАв. In convallibus Andium Granatensium inter Almaguer et Pasto, altitudine 1200-1500 hexapod. Humboldt et Bompland.

\section{Gen. XXXI. LESKEA.}

Sela lateralis. Peristomium duplex: ext, e dentibus 16: int. membrana 16-laciniata, eiliis nullis. Calyptra dimidiata.

* Capsulis magis minusve erectis,

$\dagger$ sulcatis.

1. L. sulcata; caule erecto superne ramoso, ramis pinnatis, foliis undique imbricatis erectis appressis ovato-cordatis acutis striatis, nervo attingente, seta breviuscula, capsula cylindracea sulcata, operculo rostrato. (TАB. CLXIV.)

Haв. Portus Jackson, in Nova Hollandia. D. R. Brown.

2. L. ericoides; caule elongato ramoso terete, foliis arcte imbricatis erectis ovatis subacuminatis striatis enervibus integerrimis, apice recurvo, seta brevi, capsula oblonga erecta sulcata, operculo subulato. (TАB. XXVIII.)

HaB. In sinu Dusky Bay dicto, in Nova Zeelandia. D. Menzies, 1791.

3. L. sciuroides; caule decumbente, ramis compressis curvatis, foliis undique insertis patulis ovato-acuminatis serrulatis substriatis enervibus, seta breviuscula, capsula oblonga erecta sulcata. (TAB. CLXXV.)

Haв. In insula Van Diemen. D. R. Brown.

\section{t† Capsulis lavibus.}

4. L. concinna; caule erecto bipinnato inferne nudo, foliis bifariis verticalibus stipulisque oblongis brevi-acuminatis marginatis apice serratis, nervo attingente, seta brevi, capsula erecta, operculo subulato. (TAB. XXXIV.)

НАв. In sinu Dusky Bay dicto, in Nova Zeelandia. D. Menzies, 1791. In insula Van Diemen. D.R. Brown.

5. L. maritima; caule erecto subsimplice, foliis undique imbricatis arcte appressis late ovatis acuminulatis concavis enervibus integerrimis, seta elongata, capsula cylindracea erectiuscula. (TAB. CLXVI.)

Leskea maritima. Burchell's MSS.

$\mathrm{H}_{\mathrm{AB}}$. Terrestris, in fruticetis arenosis in littore Sinus Plettenbergii, in territ, C. Bonæ Spei.- D. Burchell.

6. L. Bonplandii; caule procumbente; ramis erectis, foliis secundis deltoideo-acuminatis striatis apice serrulatis, nervo ante apicem evanescente, capsula oblonga erecta, operculo subulato. (TAB. LV. sub nomine Hookeria leskeoidis.)

$\mathrm{H}_{\mathrm{AB}}$. In sylvis Cinchonæ prope Loxam, regione temperata, altitudine 1080 hexapod. Humboldt et Bompland.

I am now satisfied that I was wrong in placing this plant in the genus Hookeria. In habit it has nothing to do with it; and what I took for 
a mitriform calyptra was a young dimidiate one not having acquired its proper figure.

\section{* Capsulis cernuis.}

7. L. laxifolia; caule procumbente pinnato, foliis laxe imbricatis, caulinis subdeltoideis, rameis ovatis, omnibus acuminatis, nervo ante apicem evanescente, seta scabra, capsula ovato-globosa, operculo conico-acuminato. (TAB. XXX.)

HAB. In plaga occidentali Americæ borealis. D. Menzies, 1791.

\section{Gen. XXXII. HYPNUM.}

Seta lateralis. Peristomium duplex: ext. e dentibus 16: int. membrana plicata 16-laciniata, ciliis alternantibus. Calyptra dimidiata.

$$
\text { * Foliis bifariis. }
$$

1. H. laricinum; caule erecto inferne denudato apice pinnatim ramoso, foliis bifariis verticalibus oblique ovatis submarginatis denticulatis, basi uninervibus, stipulis cordatis breviter acuminatis serratis, nervo perbrevi, capsula ovata nutante, operculo rostro curvato, (TAB, XXXV.)

НАв. Ad promontorium Bonæ Spei. D. Menzies, 1791. In jugis Andium regione temperata. Humboldt et Bonpland.

2. H. spininervium; caule erecto fasciculato, foliis laxis bifariis ovatis denticulatis, nervo dorso denticulato ad apicem attingente, capsula sulcata cylindracea cernua. (TАв. XXIX.)

HAв. In sinu Dusky Bay dicto, in Nova Zeelandia. D. Menzies, 1791.

3. $\boldsymbol{H}$. bifarium; caule erecto subpinnatim ramoso, foliis distantibus bifaris lanceolatis marginatis serratis, nervo ad apicem attingente, capsula ovata horizontali, operculo rostrato curvato. (TAB. LVII.) НАв. In sinu Dusky Bay dicto, in Nova Zeelandia. D. Menzies, 1791.

4. H. subbasilare; eaule suberecto, foliis bifariam imbricatis oblongolanceolatis serratis, nervo sub summum apicem evanescente, capsula oblonga pendula. (ТАв. X.)

Haв. Staten Land, prope Cape Horn. D. Menzies, 1787.

5. H. elegans; caule procumbente ramoso, foliis distichis ovato-lanceolatis enervibus apice subincurvis compressis, seta basilari, capsula cernua ovata, operculo conico-acuminato. (TAB. IX.)

Haв. Nootka, in plaga occidentali Americæ borealis, legit D. Menzies, 1787 .

\section{** Foliis undique imbricatis.}

\section{+ Caule erecto apice ramoso (Dendroidea).}

6. H. Menziesii; caule erecto, apice dense fasciculatim ramoso, ramis deflexis, folis undique imbricatis ovatis mucronulatis apice serratis, nervo excurrente dorso denticulato, capsula cylindracea pendula, operculo conico-acuto. (TAв. XXXIII.)

HАB. In sinu Dusky Bay dicto, in Nova Zeelandia. D. Menzies, 1791 ,

7. H. neckerioides; caule erecto inferne denudato, sursum pinnato, 
foliis undique imbricatis laxis ovatis obtusis apice serrulatis, nervo ante apicem evanescente, capsula oblongo-ovata inclinata. (ТАB. LVIII.)

НАв. In sinu Dusky Bay dicto, in Nova Zeelandia, D. Menzies, 1791.

8. H. Arbuscula; caule erecto bipinnatim ramoso, foliis undique imbricatis ovatis concavis integerrimis basi obsolete binervibus, seta brevi, capsula erecta ovata. (TАB. CXII.)

Hookeria Arbuscula. Smith in Linn. Trans. v. ix. p. 280. t. 23.

$\mathrm{H}_{\mathrm{AB}}$. In sinu Dusky Bay dicto, in Nova Zeelandia. D. Menzies, 1791.

计 Caule plerumque procumbente vage ramoso.

+ Foliis nervosis.

9. H. mniotdes; caule suberecto ramoso, foliis undique imbricatis erecto-patentibus flexuosis siccitate tortuosis lineari-lanceolatis serratis, nervo attingente, capsula suberecta ovato-cylindracea. (ТӒ. LXXVII).

Haв. Staten Land prope Cape Horn. D. Menzies, 1787.

10. H. stoloniferum; caule repente inferne denudato, ramis erectis pinnatim ramosis, foliis undique imbricatis erectis ovato-ellipticis acuminatis serratis, nervo ultra medium evanescente, seta breviuscula, capsula ovata cernua. (TAB. LXXIV.)

НАв. In plaga occidentali Americe occidentalis. D. Menzies, 1787.

+ Foliis enervibus.

11. H. Alexile; caule elongato flexuoso ramoso, foliis imbricatis lateovatis valde concavis obtusis integerrimis enervibus, capsula ovatocylindracea erecta. (TAB, CX.)

Hypnum flexile. Swartz Fl. Ind. Occ. p.1830.

Hypnum cochlearifolium. Schwaegr. Suppl, p. 221, t.88.

Leskea flexilis. Hedw. Sp. Musc. p. 234. t.58, Schwaegr.Suppl.p.168. Hookeria flexilis. Smith in Linn. Trans, v, ix. p. 281.

$\mathrm{H}_{\mathrm{AB}}$. In montibus summis Jamaicæ australis. Swartz. In sinu Dusky Bay dicto, in Nova Zeelandia. D. Menzies, 1791. In insula Van Diemen. D. R. Brown. In Australasia lectum communicavit cl. Labillardiere. Schwaegr.

12. H.? patens; caule erecto ramoso, foliis horizontaliter patentibus undulatis rotundatis breviter acuminatis subintegerrimis, nervo tenuissimo fere obsoleto. (TAB. LVI.)

$\mathrm{H}_{\mathrm{AB}}$. In convallibus Andium Granatensium inter Almaguer et Pasto, altitudine 1200-1500 hexapod. Humboldt et Bonpland.

13. $H$. andicolum; caule breviusculo vage bipinnatim ramoso, foliis undique imbricatis ovato-lanceolatis acuminatis obscure serrulatis enervibus, capsula ovato-cylindracea erecta, operculo rostrato. (TAB. LXXXIII.)

HaB. In crepidinibus Andium inter Tulcan et Quito. Humboldt et Bonpland.

14. H. elègantulum; caule elongato repente pinnatim ramoso, foliis patentibus late ovatis acuminatis serratis enervibus, seta elongata, capsula ovato-cylindracea cernua, operculo rostrato. (TAB. LXXXIV.) 
$\mathrm{H}_{\text {AB. }}$ Vallis de Aragua (Prov. Venezuel.) America meridionali. Humboldt et Bonpland.

*** Foliis falcato-secundis.

十 Foliis uninervibus vel basi binervibus.

15. H. crispifolium; caule repente pinnatim ramoso, foliis flaccidis falcato-secundis, caulinis deltoideis, rameis ovato-lanceolatis, omnibus serratis flexuosis longe acuminatis, seta scabra, capsula ovata cernua. (ТАв. XXXI.)

HAB. In plaga occidentali Americæ borealis. D. Menzies, 1791.

16. H. robustum; caule suberecto ramoso, foliis densissime imbricatis ovato-acuminatis falcato-secundis striatis transversim rugosis, apice subserrulatis, basi binervibus, seta breviuscula, capsula ovato-oblonga cernua. (T $\mathrm{AB}$. CVIII.)

$\mathrm{H}_{\mathrm{AB}}$. In plaga occidentali Americæ septentrionalis. D. Menzies, 1793.

\section{†† Foliis enervibus.}

17. H. tenuirostre; ramis erectis, foliis falcato-secundis ovatis longe acuminatis subintegerrimis enervibus, capsula oblongo-ovata cernua, operculo longirostrato. ( $\mathrm{T}_{\mathrm{AB}} . \mathrm{CXI}$.)

НАв. In sinu Dusky Bay dicto, in Nova Zeelandia. D. Menzies, 1791.

18. $H$. circinale; caule repente dense pinnatim ramoso, foliis lanceolato-subulatis subserratis secundis circinalibus enervibus, seta breviuscula, capsula ovata cernua, operculo conico. (TАB. CVII.)

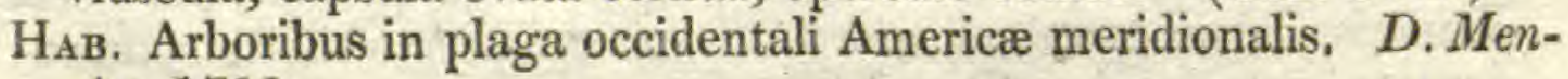
zies, 1793.

\section{HEPATIC E.}

\section{Gen. 1. JUNGERMANNIA.}

Receptaculum fructus commune nullum. Capsula pedunculo calyce longiore insidens, quadrivalvis. Columella nulla.

\section{A. Folioser. \\ + Exstipulatie.}

a. Foliis multifariam imbricatis.

1. J. quadripartita; caule erecto subdichotome ramoso flexuoso, folis distantibus erecto-patulis 4-partitis, segmentis capillaribus integerrimis vel basi sublaciniatis. (TАB. CXVII.)

НАв. In insula Staten Land dicta, prope Cape Horn. D. Menzies, 1787.

2. J. scolopendra; caule erecto pinnatim ramoso, ramis deflexis attenuatis, foliis oblongis bifidis, segmentis bifidis, calyce laterali foliaceo. (TAB. XL.)

HaB. In sinu Dusky Bay dicto, in Nova Zeelandia, D. Menzies, 1791. 


\section{b. Foliis bifariis. \\ * Foliis integris.}

3. J. saccata; caule procumbente, ramis erectis, foliis ovato-quadratis denticulatis, fructu terminali, calycibus oblongis carnosis pendulis. (TÁs. XVI.)

Haв. In sinu Dusky Bay dicto. D. Menzies, 1791.

4. J. falcata; caule subrepente, ramis erectis attenuatis insigniter falcatis, foliis erectis appressis rotundatis denticulatis, calyce laterali ex inferna parte caulis oblongo carnoso, basi squarnosa, seta longissima. (TAB. LXXXIX.)

Haв. In sinu Dusky Bay dicto, in Nova Zeelandia. D. Menzies, 1791.

5. J.adiantoides; caule repente, ramis erectis divisis, foliis horizontalibus dimidiato-ovatis denticulato-ciliatis, calyce terminali urceolato, ore compresso fimbriato, seta brevi. (ТАB. XC.)

J. adiantoides. Swartz Fl. Ind. Occ, p. 1842.

J. annotina. Menzies' MSS.

HAB. In summis montibus Jamaicæ locis subhumidis umbrosis. D. O. Swartz. In sinu Dusky Bay dicto, in Nova Zeelandia. D. Menzies, 1791.

6. J. conjugata; caule repente, ramis erectis divisis, foliis erectis appressis rotundatis spinuloso-dentatis oppositis atque basi per paria connatis, calyce terminali urceolato, ore compresso ciliato spinosodentato, seta brevi. (T $\mathrm{T}_{\mathrm{AB}} . \mathrm{XCI}$.)

Hав. In sinu Dusky Bay dicto, in Nova Zeelandia. D. Menzies, 1791.

7. $\boldsymbol{J}$. ramosissima ; caule erecto elongato subfastigiatim ramoso, foliis arcte imbricatis ovato-rotundatis spinuloso-dentatis, calyce terminali urceolato, ore compresso ciliato-spinoso, seta brevi. ('TAB. XCII.)

$\mathrm{H}_{\mathrm{AB}}$. In sinu Dusky Bay dicto, in Nova Zeelandia. D. Menzies, 1791.

8. J.gigantea; caule ascendente fastigiatim ramoso, foliis distichis rotundato-quadratis denticulato-ciliatis, calyce terminali oblongo, ore dilatato compresso ciliato, seta breviuscula. (TAB. XCIII.)

$\mathrm{H}_{\mathrm{AB}}$. In sinu Dusky Bay dicto, in Nova Zeelandia. D. Menzies, 1791.

9. J. repanda; caule repente ramoso, ramis erectis, foliis exacte distichis arcte imbricatis horizontalibus oblongo-ovatis planis, basi decurrentibus, omnino integerrimis. (TAB, LXXXVI.)

J. repanda. Schwaegr. Hist. Musc. Hepat. Prodr. p. 26.

НAB. In insula Franciæ. D. Aubert du Petit Thouars.

\section{* * Foliis bilobis.}

10. J. pinnatifolia ; caule erecto ramoso, foliis dense imbricatis eiliatis conduplicatis, lobis inciso-pinnatis, calyce terminali oblongo quadrifido, segmentis inciso-pinnatis ciliatis. ( $\mathrm{T}_{\mathrm{AB}} . \mathrm{CXIV}$.)

Has. In sinu Dusky Bay dicto, in Nova Zeelandia. D. Menzies, 1791. 
11. J. densifolia; caule erecto subsimplice, foliis dense imbricatis ciliatis conduplicatis profunde bilobis, segmentis æqualibus oblongis. (TAB. XXXVI.)

$\mathrm{H}_{\mathrm{AB}}$. Staten Land Americæ meridionalis. D. Menzies, 1787.

\section{*** Foliis auriculatis.}

12. J.sphagnoides; caule adscendente ramoso, foliis imbricatis lanceolatis denticulatis convexis, basi subtus auriculatis, auricula oblonga inflata, calyce laterali oblongo plicato apice denticulato. (TAB. XLVII.)

J. sphagnoides, Rich. MSS. Schwaegr.Hist. Musc.Hepat.Prodr.p.33. HАв. In insula Sanctæ Helenæ. D. Menzies, 1795 ; et D. Burchell. In insula Franoiæ et Borboniæ legit Aubert du Petit Thouars.

\section{† Stipulata.}

a. Foliis integris vel apice magis minusve emarginatis.

13. J.horizontalis; caule elongato subramoso, foliis distichis horizontalibus ovato-quadratis decurrentibus, basi superiore dilatata, stipulis minutis sublunulatis, calyce laterali, ex inferiore parte caulis, oblongo-ovato, ore laciniato. (TAB. XCVI.)

НАв. In Staten Land Americæ meridionalis. D. Menzies, 1787.

14. J. Billardieri; caule erecto dichotome ramoso, foliis arcte imbricatis ovatis spinuloso-denticulatis, stipulis magnis transversim oblongis denticulatis. (TAB. LXI.)

J. Billardieri. Schwaegr, Musc. Hepat. Prodr. p. 19.

HAB. In sinu Dusky Bay dicto, in Nova Zeelandia. D. Menzies, 1791. In insula Van Diemen. D. La Billardiere.

15. J. sinuosa; caule elongato erecto subramoso, foliis distichis horizontalibus oblongis decurrentibus bidentatis, margine superiore undulato, stipulis 5-fidis segmentis laciniatis, calyce laterali, ex inferiore parte caulis, ovato, ore ciliato. (ТАв. CXIII.)

$\mathrm{H}_{\mathrm{AB}}$. In sinu Dusky Bay dicto, in Nova Zeelandia. D. Menzies, 1791.

16. J. serrulata; caule erecto dichotomo, foliis distichis vel secundis subrotundatis subcondupäicatis spinuloso-dentatis apice emarginatis, stipulis magnis rotundatis convexis spinuloso-dentatis apice emarginatis, calyce cylindraceo, ore dentato. (TAв. LXXXVIII.)

J. serrulata. Swartz Fl. Ind. Occ. p. 1854. Schwaegr. Hist. Musc. Hepat. Prodr. p. 19.

J. Aubertii ejusd. op. p. 19.

$\mathrm{H}_{\mathrm{AB}}$, In subhumidis umbrosis montium altissimorum Jamaicæ. Swartz. In insula Franciæ. D. Aubert du Petit Thouars.

17. J. coalita; caule repente vage ramoso, foliis distichis horizontalibus ovato-quadratis, apice bidentatis, stipulis iis coadunatis $5-6$ dentatis, calyce, ex parte inferiore caulis, obovato attenuato, ore 4-dentato. (TAB, CXXIII.)

НАв. In sinu Dusky Bay dicto, in Nova Zeelandia: D. Menzies, 1791. 
b. Foliis varie fissis.

* Foliis subaqualiter bilobis.

18. J. squarrosa; caule elongato erecto subsimplice squamoso, foliis densissime imbricatis distichis squarrosis subquadratis undulatis, lobis cuspidatis integerrimis vel unidentatis, stipulis magnis bifidis segmentis ovatis cuspidatis, margine laciniatis. (TAB. LXXVIII.)

J. squarrosa. Menzies' MSS.

НАв. In sinu Dusky Bay dicto. D. Menzies, 1787.

19. J. fimbriata; caule elongato erecto subsimplice squamoso, foliis densissime imbricatis distichis squarroso-recurvis bifidis, segmentis ovatis cuspidatis ciliato-spinosis, stipulis bifidis segmentis lanceolatis recurvis ciliato-spinosis, calyce terminali oblongo plicato. (ТАB. LXXIX.)

J. fimbriata. Richard MSS.

Нав. In insula Borboniæ. D. Prof. Richard.

20. J. lamellata; caule erecto diviso, foliis dense bifariam imbricatis horizontalibus conduplicatis, lobis ovatis dorso lamellatis, lamellis spinoso-dentatis, apice inciso-pinnatifidis, laciniis denticulatis, stipulis bilobis spinoso-dentatis. (TAв. XLIX.)

HАв. Staten Land, prope Terram del Fuego, Americæ meridionalis: D. Menzies, 1787.

\section{* * Foliis incequaliter brlobis.}

21. J. nobilis; caule suberecto flexuoso, foliis arcte bifariam imbricatis horizontalibus, lobis ovatis ciliato-dentatis conduplicatis verticalibus, stipulis rotundatis emarginatis ciliatis, calyce oblongo compresso, ore laciniato, laciniis ciliato-dentatis. (TАB. XI.)

Нав. Dusky Bay, in Nova Zeelandia. D. Menzies, 1791.

22. J.glaucescens; caule erecto, foliis bifariis horizontalibus pubescentibus, lobis conduplicatis ovatis, stipulis quadrifidis, calyce terminali foliaceo. (ТАв. XXXIX.)

Нав. In sinu Dusky Bay dicto, in Nova Zeelandia. D. Menzies, 1791.

23. J. lanata; caule erecto compresso pinnatim ramoso, foliis bifariis horizontalibus, lobis conduplicatis stipulisque ciliato-multifidis, calyce oblongo pubescente. (TAB. CXVI.)

HАв. In sinu Dusky Bay dicto, in Nova Zeelandia. D. Menzies, 1791.

24. J. crispata; caule procumbente pinnatim ramoso, foliis bifariis integerrimis crispatis, lobis superioribus majoribus ovatis, inferioribus ligulatis, stipulis cordatis. (ТАв. CXLIII.)

$\mathrm{H}_{\mathrm{AB}}$. In umbrosis montis Quindiu ad radices Quercus Granatensis juxta la Guebrada de Torha, altit. 1050 hexapod. Humboldt et Bonpland.

25. J. flagellifera ; caule erecto pinnatim ramoso, ramis flagelliformibus, foliis distiche imbricatis conduplicatis, lobis lobulisque ovatolanceolatis acutis integerrimis, stipulis ovatis acute bifidis basi utrinque unidentatis. (TAB. LIX.) 
Has. In sinu Dusky Bay dicto, in Nova Zeelandia. D. Menzies, 1791.

26. J. filicina ; caule erecto pinnatim ramoso, lobis superioribus majoribus ovatis acutiusculis apice serratis, inferioribus minutis subrotundatis conduplicatis, stipulis obovato-quadratis serratis, calycibus lateralibus oblongo-obcordatis apiculatis. (TAB. CXLII.)

Jungermannia filicina. Swartz Fl. Ind. Occ. p. 1866. Schwaegr. Musc. Hepat. Prodr. p. 18.

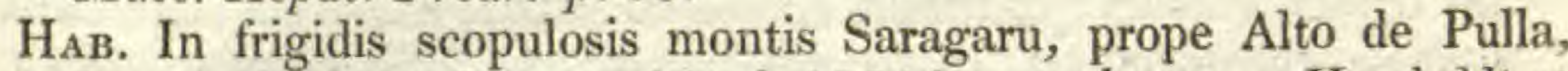
Loxam inter et Onam, altitud. 1564 hexapodarum. Humboldt et Bonpland.

27. J. appendiculata; caule suberecto, foliis dense bifariam imbricatis horizontalibus, lobis verticalibus ovatis, posterioribus apicem versus pinnato-incisis serratis, anterioribus serratis posterioris lobi paginæ affixis. ( $\mathrm{T}_{\mathrm{AB}} . \mathrm{XV}$.)

HAB. Dusky Bay, in Nova Zeelandia. D.Menzies, 1791.

28. $J$. Thouarsii; caule ascendente, foliis bifariam imbricatis horizontalibus, lobis verticalibus ovatis spinoso-denticulatis, minoribus majoris lobi paginæ affixis, stipulis quadratis emarginatis denticulatis. (TAB. XLVIII.)

HaB. Insula Franciæ. D. Aubert du Petit Thouars. *** Foliis quadrifidis.

29. J. pulchella; caule elongato erecto subsimplice, foliis bifariis distichis subquadratis quadri-lobis pulcherrime ciliatis, stipulis latis 5-6-lobis ciliatis, calyce terminali oblongo plicato, ore ciliato. (TAB. XCIV.)

НАв. In sinu Dusky Bay dicto, in Nova Zeelandia. D. Menzies, 1791.

30. J. pendulina; caule erecto pinnatim ramoso, ramis pendulis flagelliformibus, foliis superne imbricatis stipulisque valde concavis rotundatis quadrifidis. (TАB. LX.)

HАB. In sinu Dusky Bay dicto, in Nova Zeelandia. D. Menzies, 1791.

31. J. microphylla; caule erecto pinnatim ramoso, ramis pendulis capillaribus, foliis distantibus oblongo-quadratis, stipulisque lato-quadratis, minutis planis quadrifidis. (TАB, LXXX.)

J. sertularioides. Menzies' MSS.

$\mathrm{H}_{\mathrm{AB}}$. In sinu Dusky Bay dicto, in Nova Zeelandia. D. Menzies, 1791. Ex insula Guadaloupe miserunt Prof. O. Swartz et D.Palisot de Beauvois.

\section{*** Foliis auriculatis.}

32. J. lobulata; caule repente ramoso, foliis ovato-rotundatis, auriculis rotundatis folio vix minoribus, stipulis rotundatis planis emarginatis, calyce oblongo-ovato lævi triangulari. (T.

HАв. In insula Staten Land dicta, prope Cape Horn. D. Mensies, 1787.

33. J. clavigera; caule repente bipinnatim ramoso, foliis rotundatis acutis integerrimis, auriculis bifidis, segmento uno claviformi, altero 
oblongo planiusculo, stipulis quadrifidis margine revolutis integerrimis, ramorum segmentis duobus intermediis claviformibus saccatis, calyce axillari folioso, foliis integerrimis. (TAB. LXX.)

HAB. In sinu Dusky Bay dicto, in Nova Zeelandia. D. Menzies, 1791.

34. J.palpebrifolia; caule repente bipinnatim ramoso, foliis rotundatis ciliato-spinosis, auriculis bifidis, segmento uno claviformi, altero bi- trifido, stipulis quadrifidis ciliato-laciniatis, ramorum segmentis duobus claviformibus, calyce axillari folioso, foliis ciliatis. (TAB. LXXI.)

Haв. In sinu Dusky Bay dicto, in Nova Zeelandia. D.Menzies, 1791 .

35. J. magellanica; caule repente tripinnatim ramoso, foliis ovatorotundatis ciliato-spinosis, auriculis bifidis, segmentis oblongis ciliatis, uno sæpissime claviformi, stipulis late ovatis emarginatis margine recurvis (ramulorum bifidis laciniatis rarius claviformibus), calyce oblongo, ore dentato. (TАB. CXV.)

J. magellanica. Lam. Encycl. Bot. v. iii. p. 28. Schwaegr. Musc. Hepat. Prodr. p. 14. t. 1 .

J. elegans. Richard MSS.

$\mathrm{H}_{\mathrm{AB}}$. In freto Magellanico. Commerson. In Staten Land prope Cape Horn. D. Menzies, 1787.

36. J. Menziesii; caule repente dense bipinnatim ramoso, foliis rotundatis ciliatis, auriculis oblongis ciliatis claviformibus, stipulis quadrifidis ciliatis, ramorum segmentis duobus claviformibus. (TAB. CXVIII.)

Haв. In insula Staten Land dicta, prope Cape Horn. D. Menzies, 1787.

\section{B. FroNdOSF.}

37. J. Phyllanthus, stipitata; frondibus ovato-lanceolatis simplicibus nervosis integerrimis, fructu e costa superiore frondis basin versus, calyce duplice, ext. parvo squamoso, int. oblongo cylindraceo carnoso. (TAB. XCV.)

НАв. In sinu Dusky Bay dicto, in Nova Zeelandia. D. Menzies, 1791.

38. J.rhizobola, stipitata; frondibus oblongis dichotomis nervosis marginatis denticulatis, apice longissime attenuato radicante. (TAB. LXXXVII.)

J. rhizobola. Schwaegr. Musc. Hepat. Prodr. p. 31.

$\mathrm{H}_{\mathrm{AB}}$. In insula Borboniæ. D. Aubert du Petit Thouars,

39. J. flabellata, stipitata; frondibus suborbiculatis palmatis dichotome radiatis nervosis integerrimis, fructu in dichotomiarum axillis, calyce duplice, ext. brevi bilabiato, int. oblongo-cylindraceo, ore laciniato. (TAB. XIII.)

Jungermannia flabellata. Labill. Fl. Nov. Holl. v. iii. p. 109, t, 254. $f .1$.

HAB. In capite Van Diemen. Labillardiere. In sinu Dusky Bay dicto, in Nova Zeelandia. D. Menzies, 1791. 
40. J.Hymenophyllum, stipitata; frondibus palmatis dichotomis nervosis denticulatis, fructu in dichotomiarum axillis, calyce duplice; ext. squama exigua dentata; int. oblongo-cylindraceo, ore dentato. (TAB. XIV.)

НАв. In sinu Dusky Bay dicto, in Nova Zeelandia. D. Menzies, 1791.

41. J. eriocaula; caudice compresso lineari pubescente, frondibus alternis ovatis bipinnatis, pinnis angustis linearibus glabris, nervo crasso, fructu axillari, calyce nullo (?), corolla lineari-oblonga carnosa. (TАв. LXXII.)

НАв. In sinu Dusky Bay dicto, in Nova Zeelandia. D. Menzies, 1791.

42. $J$. fucoides; caudice compresso lineari glabro, frondibus alternis ovatis subpinnatis, pinnis latiusculis linearibus, nervo subangusto (fructu axillari, corolla terete longiuscula carnosa. $S w$.). (TAB. LXXXV.)

J. fucoides. Swartz Fl. Ind. Occ. p. 1872.

$\mathrm{H}_{\mathrm{AB}}$. Inter muscos in depressis umbrosis montium altissimorum $\mathrm{Ja}$ maicæ australis. D. O. Swartz.

\section{Gen. II. MONOCLEA.}

Receptaculum fructus commune nullum. Capsula pedunculo calyce longiore insidens, univalvis, hinc longitudinaliter dehiscens. Columella nulla.

1. M. Forsteri. (ТАв. CLXXIV.)

Anthoceros univalvis. G. Forster's MSS.

HAB. Insulæ australes, D, G, Forster (in Herb. Lambert). 


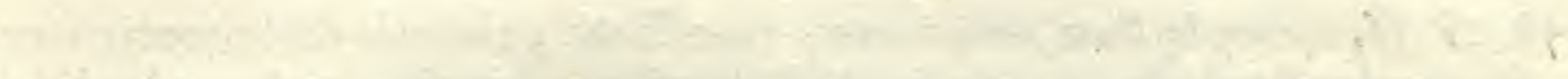

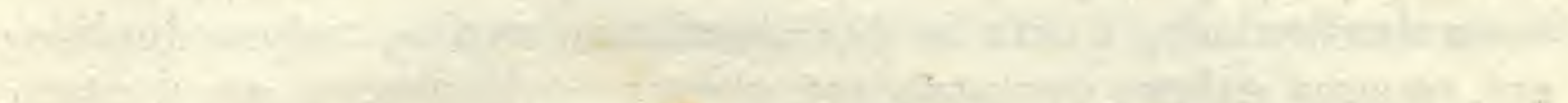

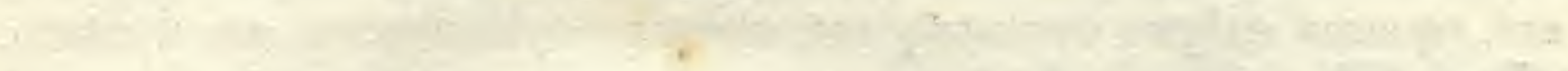

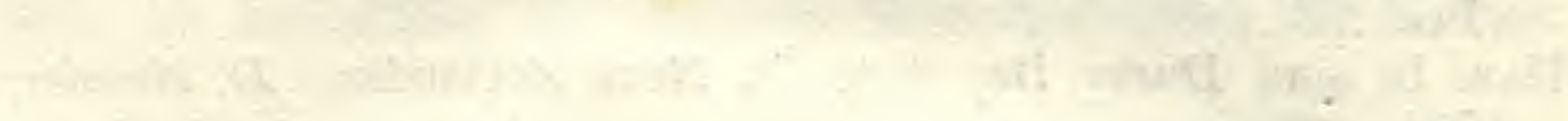

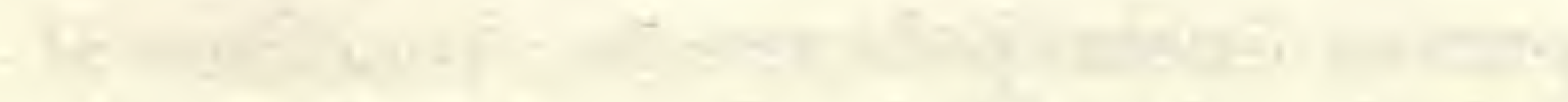

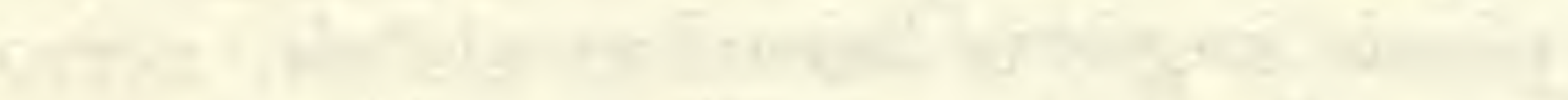

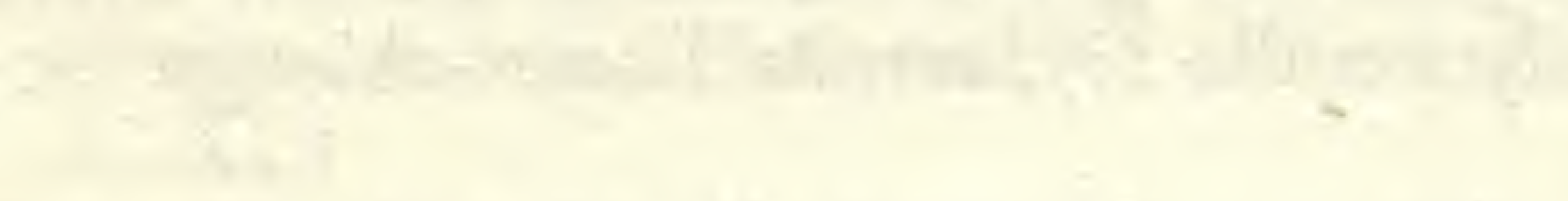

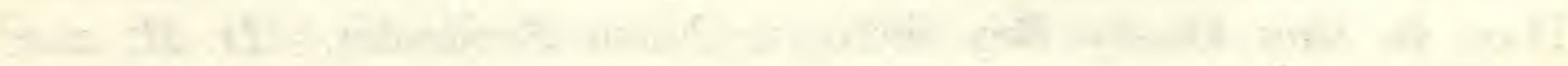

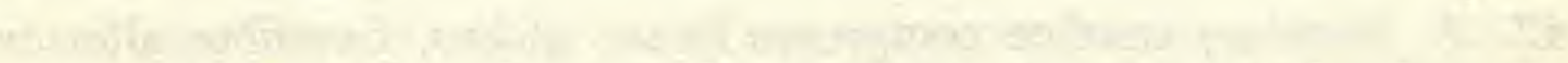

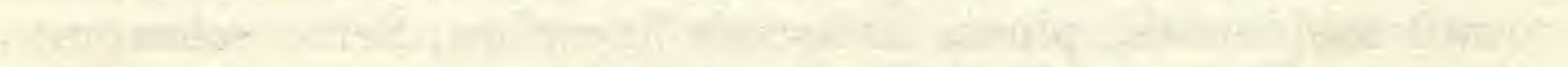

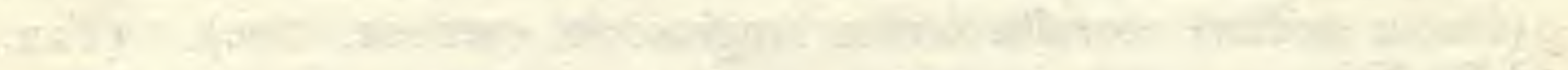

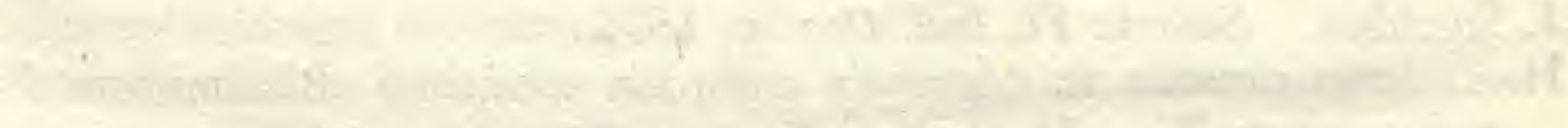

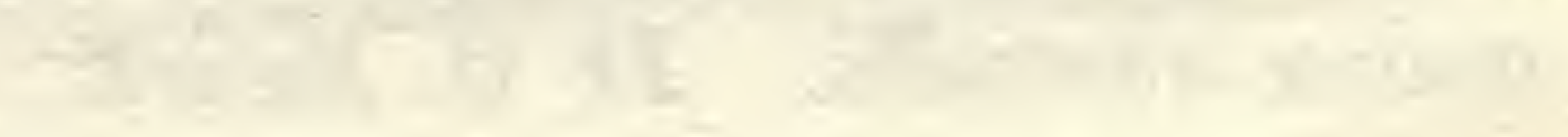

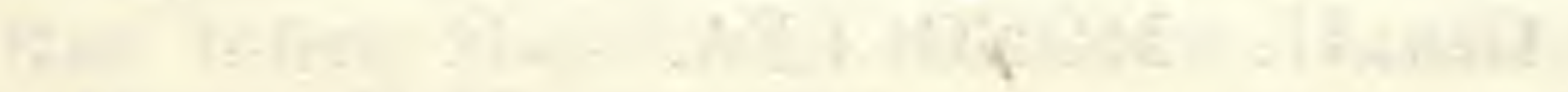

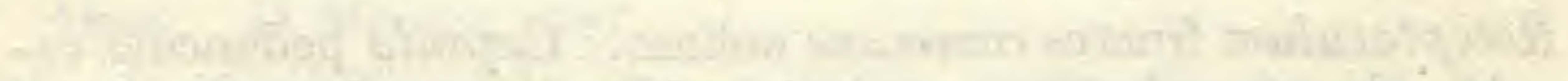

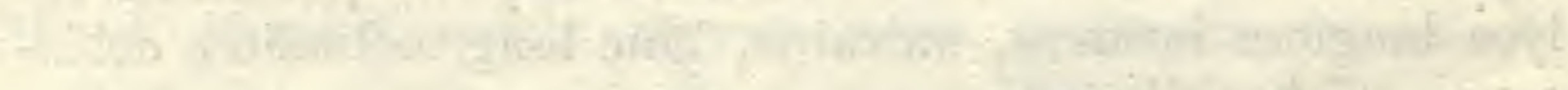

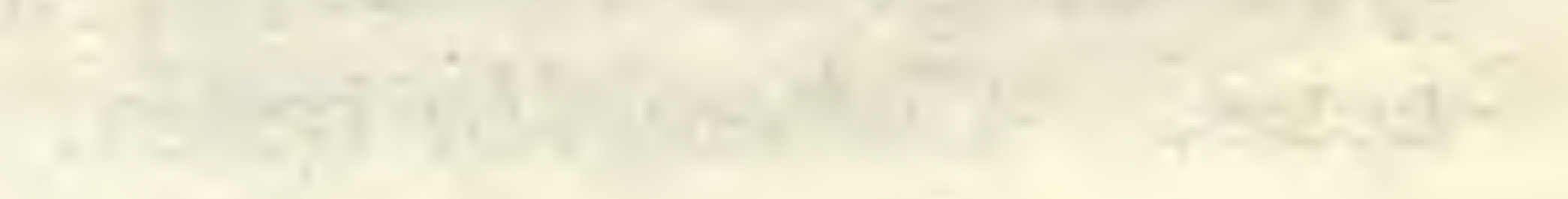

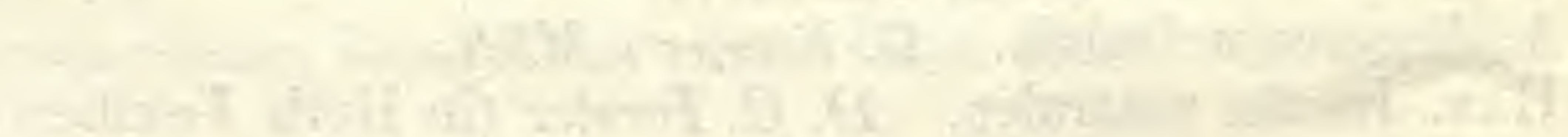




\section{ALPHABETICAL INDEX}

TO THE

\section{FIRST AND SECOND VOLUMES.}

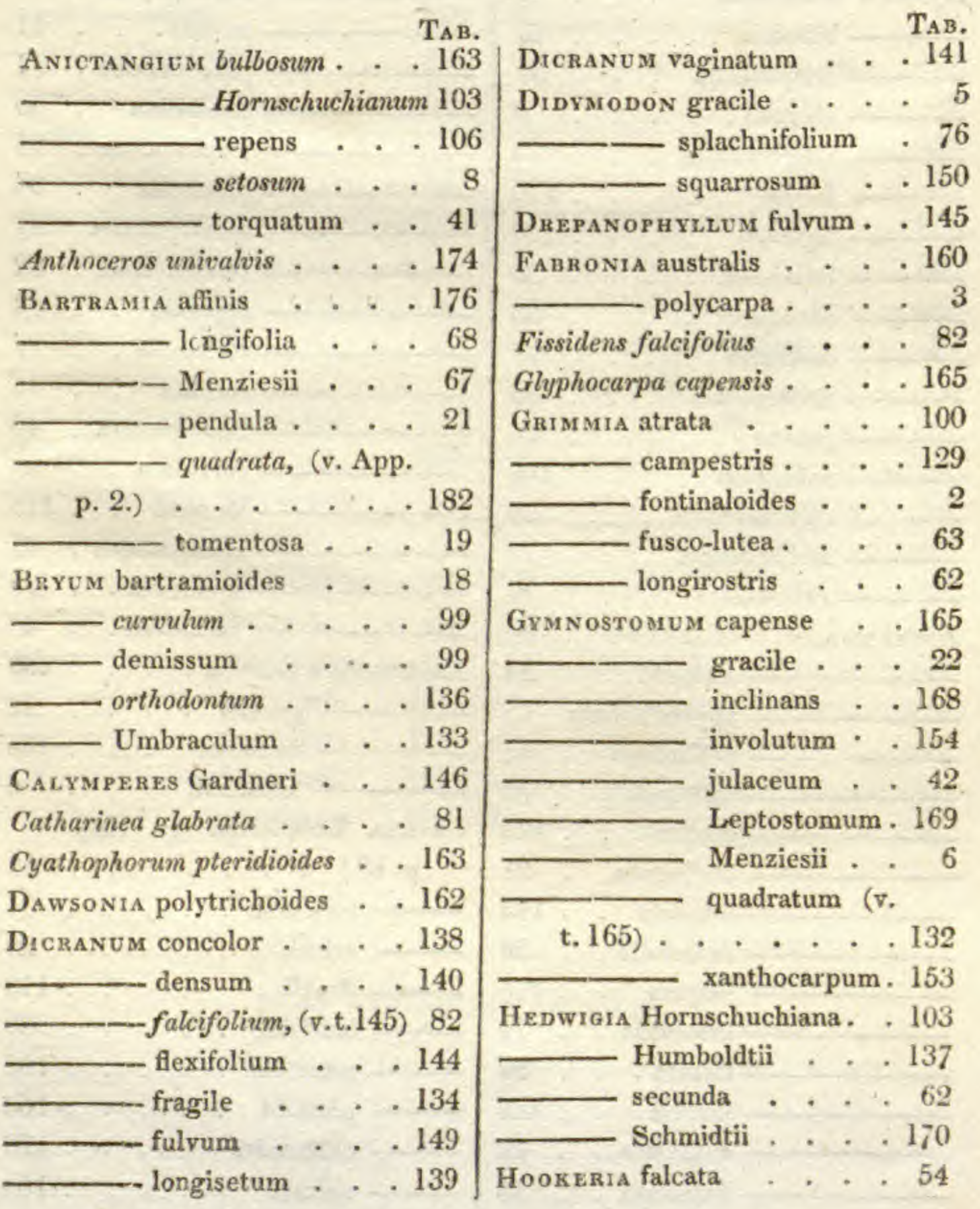


Hookeria flexilis . . . . . 110 Langsdorfii . . . 121
- leskeoides (v. App. p. 18.). . . . . 55

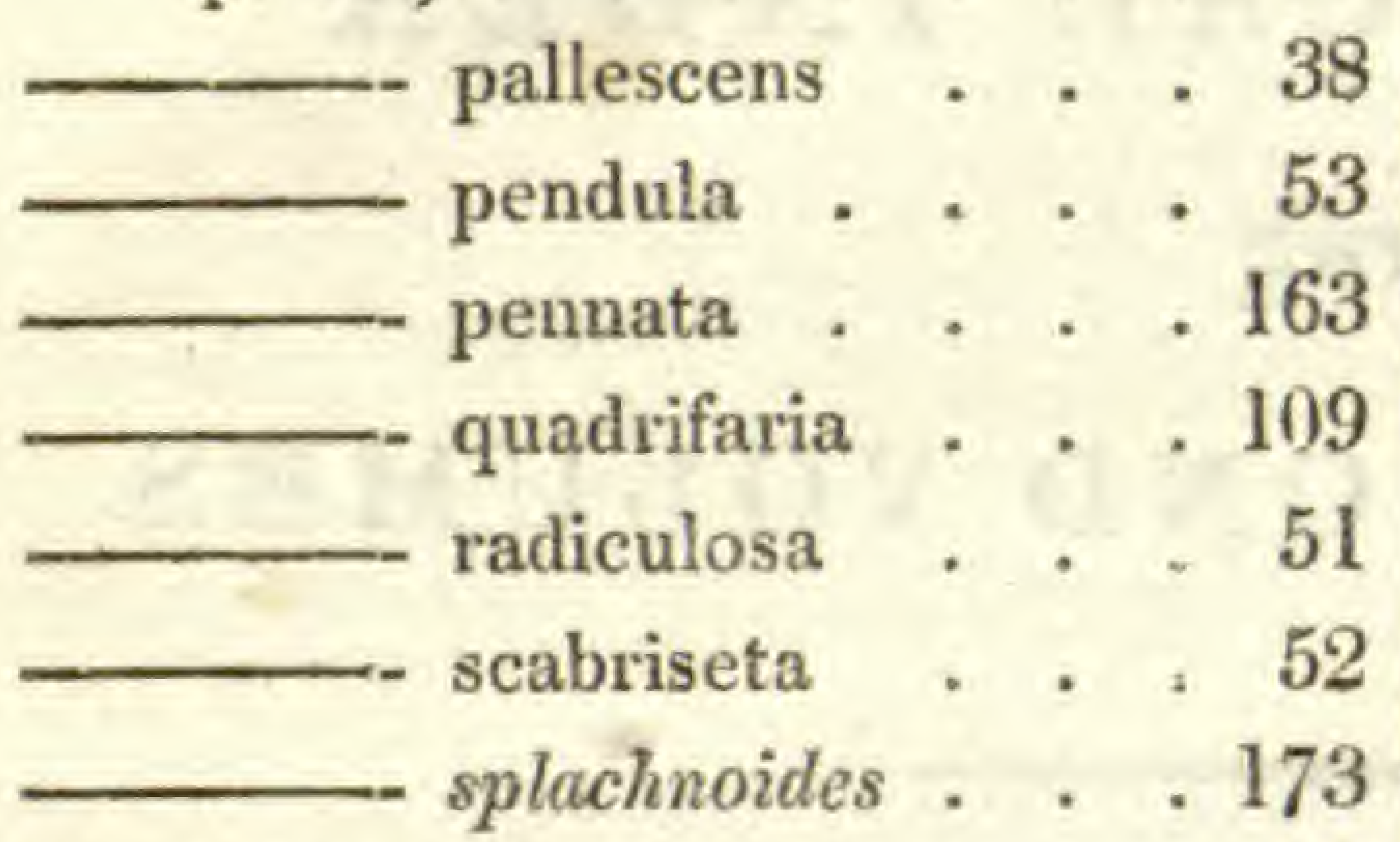
HYPNUM andicolum . . . . 83

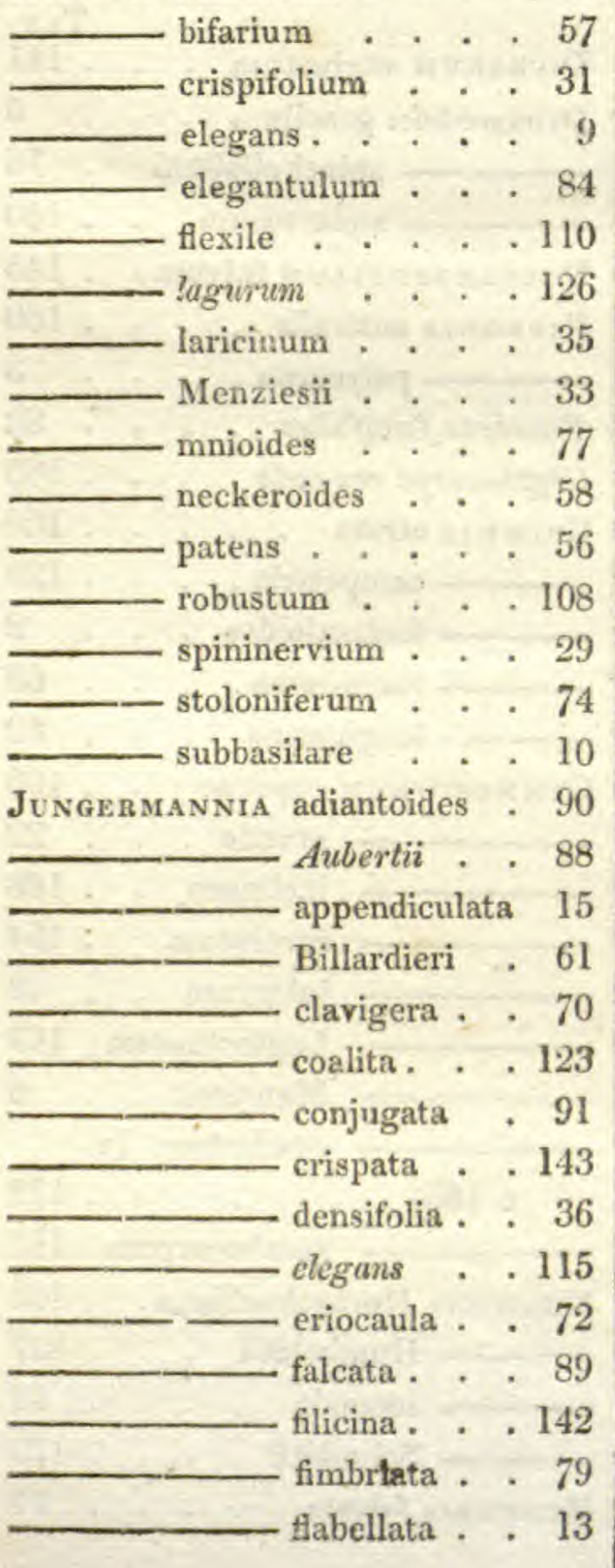

JUNGERMANNIA flagellifera . 59 —_ fucoides . . 85 Hymenophyllum 14 lamellata . . 49 lanata . . . 116 lobulata . . 119 Magellanica - 115 Menziesii . . 118 microphylla . 80 nobilis . . 11 palpebrifolia ? 71 pendulina $\quad 60$ Phyllanthus . 95 pulchella . . 94 quadripartita . 117 ramosissima . 92 repanda . . 86 rhizobola . . 87 saccata . 16 Scolopendra . 40 serrulata . . 88 sinuosa . . 113 sphagnoides . 47 squarrosa . 78 Thouarsii . . 48

Leptostomum erectum . . . . 169 - gracile . . . . 22 inelinans . . 168 Menziesii . . . 6

Leskea Bonplandii (v. App. p. 18.) . . . . 55 concinna . . . . . 34 ericoides . . . . . 28 flexilis . . . . 110 laxifolia . . . 30 maritima .. . . 166 pennata . . . . 163 sciuroides . . . 178 sulcata 
LEUCODON calycinus . . . 17 lagurus . . . 126 pallidus

LEUCODON rugosus . . . . 20 tomentosus . . . 37

LYELLIA crispa . . . . 161 Meesia demissa . . . . . . 99 Mnium pendulum . . . . . 21 - tomentosum . . . . 19 Monoclea Forsteri . . . 174 Neckera acuminata , . . 151 — abietina . . . . 7 - affinis . . . . . 122 — composita $\beta$. . . 122

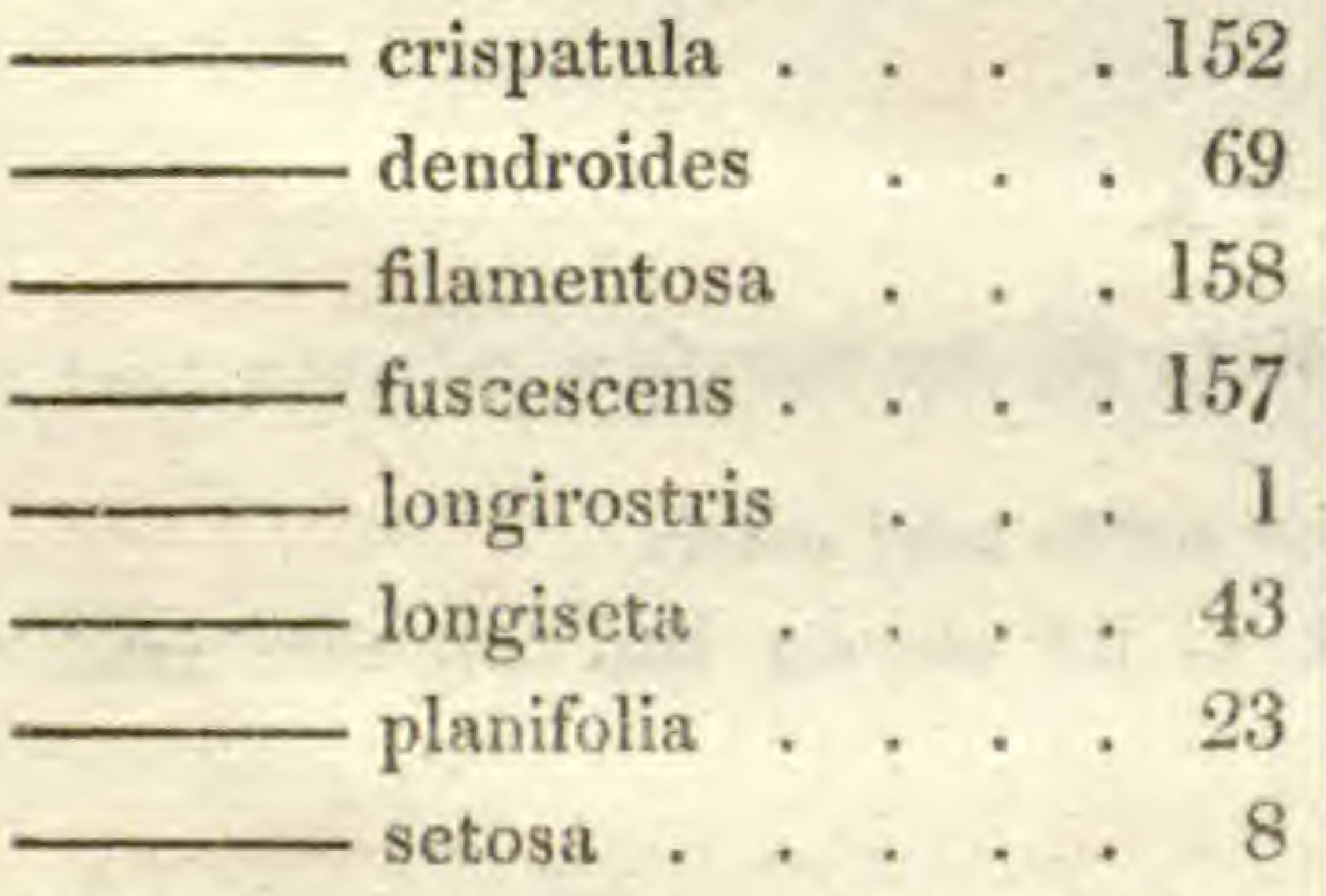

OctólEPHARUM serratum . 136 Orthodon . . . . . . 136 Orthotrichum apiculatum 45 - gracile . . 27 - longifolium . 44 - longipes . . 24 - longirostre . 25 prorepens . 120 rugifolium . 128 Swainsoni $\quad 127$ urceolatum . 124
Phascum nervosum . . . 105

Polytrichum angustatum . 50

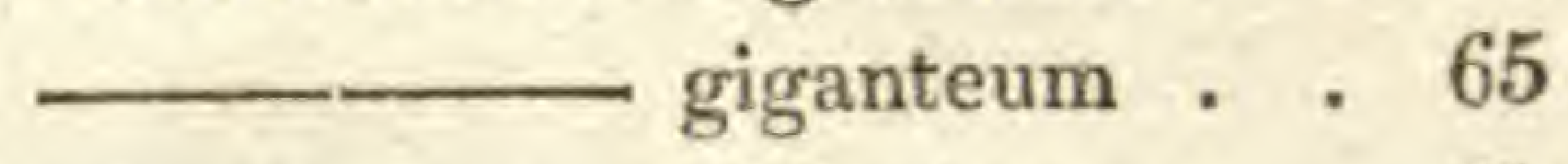

-

—— lævigatum . 81

longisetum . . 66

- tenuirostre . . 75

Pterogonium aureum . . 147 flavescens . . 155

myurum . . . 148

- pulchellum . . 4

Pterigophorum pennatum, 163

Sclothermia sulcata . . 156

Splachnum octoblepharum .167

- scabrisetum . . 32

- squarrosus $\quad . \quad 136$

Systylium splachnoides . . 98

TAYLORIA splachnoides . . 173

Tortula flexuosa . . 125

- indica . . . . . 135

- membranifolia . . 26

— pilifera . . . . . 12

— recurvata . . . 130

Trichostomum indicum . 135

perichætiale .73

- vaginatum . 64

Vortra nivalis . . . . . 97

Werssia ciliata . . . 171

- elongata . . . . 102

Martiana . . . . 104 Mielichoferi . . 105 pomiformis . . . 135

ZYGODON obtusifolium . . . 159 


\section{ERRATA.}

Sub Octoblepharum serratum, t. CXXXVI.I . 39, for mitriform calyptra read divosdiate.

Sub Hyphum laricinum, t. XXXV. 1.5, for erectis read ovatis.

Sub Jungermannia coalita, t. CXXIII. I. 6, for obovala basi attenuata read olovato basi altenualo. 